\title{
Refractory Experience in Circulating Fluidized Bed Combustors, Task 7
}

\author{
Final Report
}

\section{R.Q. Vincent}

November 1989

Work Performed Under Contract No.: DE-AC21-85MC22012

For

U.S. Department of Energy

Office of Fossil Energy

Morgantown Energy Technology Centir

Morgantown, West Virginia

By

Fluidized Bed Technologies, Inc.

Chattanonga, Tennessee

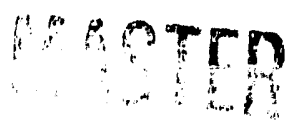




\section{DISCLAIMER}

This report was prepared as an account of work sponsored by an agency of the United States Government. Neither the United States Government nor any agency thereof, nor any of their employees makes any warranty, express or implied, or assumes any legal liability or responsibility for the accuracy, completeness or usefulness of any information, apparatus, product, or process disclosed, or represents that its use would not infringe privately owned rights. Reference herein to any specific commercial product, process, or service by trade name, trademark, manufacturer, or otherwise, does not necessarily constitute or imply its endorsement, recommendation, or favoring by the United States Government or any agency there of. The views and opinions of authors expressed herein do not necessarily state or reflect those of the United States Government or any agency thereof.

This report has been reproduced directly from the best available copy.

Available to DOE and DOE contractors from the Office of Scientific and Technical Information, P.O. Box 62, Oak Ridge, TN 37831; prices available from (615)576-8401, FTS 626-8401.

Available to the public from the National Technical Information Service, U.S. Department of Commerce, 5285 Port Royal Rd., Springfield, VA 22161. 


\title{
Refractory Experience in Circulating Fluidized Bed Combustors, Task 7
}

\author{
Final Report
}

R.Q. Vincent

Work Performed Under Contract No.: DE-AC21-85MC22012

\author{
For \\ U.S. Department of Esergy \\ Office of Fossil Energy \\ Morgantown Energy Technology Center \\ P.O. Box 880 \\ Morgantown, West Virginia 26507-0880
}

Fluidized Bed Technologies, Inc.

100 Cherokee Boulevard

P.O. Box 4469

Chattanooga, Tennessee 37405

November " 789 
ABSTRACT

This report describes the results of an investigation into the status of the design and selection of refractory materials for coal-fueled circulating fluidized-bed combustors. The survey concentrated on operating units in the United States manufactured by six different boiler vendors: Babcock and Wilcox, Combustion Engineering, Foster Wheeler, Keeler Dorr-Oliver, Pyropower, and Riley Stoker. Information was obtained from the boiler vendors, refractory suppliers and installers, and the owners/operators of over forty units. This work is in support of DOE's Clean Coal Technology program, which includes circulating fluidized-bed technology as one of the selected concepts being evaluated. 
ACKNOWLEDGEMENTS

The contents of this report would not be possible without the cooperation and input received from the various boiler vendors, refractury suppliers and installers, and owner/operators. The time taken out by these individuals to answer questions, provide reports, and allow site visits is appreciated. The author wishes to thank Mr. Joseph E. Macko, DOE Program Manager, for his guidance and technical review of the report. 
$\underline{\text { PAGE }}$

$\begin{array}{lll}1.0 & \text { INTRODUCTION } & 1\end{array}$

2.0 OBJECTIVE 2

3.0 SCOPE 3

4.0 CFB DESCRIPTION AND REFRACTORY REQUIREMENTS 12

$\begin{array}{lll}5.0 & \text { SURVEY RESULTS } & 21\end{array}$

$\begin{array}{lll}5.1 & \text { BOILER VENDORS } & 21\end{array}$

5.1.1 BABCOCK AND WILCOX 22

5.1 .2 COMBUSTION ENGINEERING 24

5.1 .3 FOSTER WHEELER 26

5.1 .4 KEELER DORR-OLIVER 27

5.1 .5 PYROPOWER 28

5.1 .6 RILEY STOKER 29

5.2 CFB OWNER/OPERATOR 32

5.2.1 NEW BRUNSWICK POWER 33

5.2.2 AMERICAN LIGNITE PRODUCTS 34

5.2 .3 WESTWOOD ENERGY 36

5.2.4 SCOTT P'IPER 37

5.2.5 FORT HCWARD PAPER 38

5.2.6 FRACKVILLE COGENERATION 39

5.2 .7 ARCHER DANIEL MIDLAND 40

5.2.8 COLORADO-UTE 41

5.2 .9 CENTRAL SOYA 48

5.2 .10 B. F. GOODRICH 49

5.2.11 CALIFORNIA PORTLAND CEMENT 50

5.2 .12 GENERAL MOTORS-ARGONAUT 52

5.2 .13 IOWA STATE UNIVERSITY 53

5.2 .14 PYROPOWER UINIT

5.2.15 GILBERTON 55

5.2.16 UNIVERSITY OF MISSOURI 56

5.2.17 GENLRAL MOTORS - FORT WAYNE 58

5.2 .18 UNIVERSITY OF IOWA 59

5.2 .19 A. E. STALEY 60 
TABLE OF CONTENTS (CONTINUED)

6.0 SUMMARY/RECOMMENDATIONS 61

6.1 MATERIAL SELECTION 62

6.1 .1 INSULATING 62

6.1 .2 ABRASION RESISTANT 62

6.2 INSTALLAIION METHODS 63

6.2.1 GUNNING 63

6.2 .2 CASTING 64

6.2 .3 RAMMING 64

6.3 ANCHORING 65

6.4 STAINLESS STEEL FIBERS 66

6.5 MOISTURE VENTING FIBER 66

6.6 CORROSION 66

6.7 QUALITY CONTROI 67

$\begin{array}{ll}7.0 & \text { REFERENCES } \\ \end{array}$

APPENDIX A - REFRACTORY SUPPLIER INFORMATION 69

- A.P. GREEN

- COMBUSTION ENGINEERING (PREMIER)

- HARBISON-WALKER

- NORTH AMERICAN REFRACTORIES

- NORTON

- PLIBRICO 


\subsection{INTRODUCTION}

The U.S. Department of Energy (DOE) is actively involved in the implementation of a Clean Coal Technology (CCT) program. Two rounds of solicitation and selection have occurred with the third solicitation currently out for proposals. One of the key technologies that has already been identified and selected under this program is fluidized-bed combustion and, in particular, atmospheric circulating fluidized-bed (CFB) combustion.

The DOE has selected proposals from three CFB facilities. The Colorado-Ute Electric Association (CUEA) CFB at Nucla, Colorado was selected under the first round CCT solicitation. The CUEA project involves the replacement of three stoker fired units with a Pyropower CFB. In addition, the plant was upgraded from $36-\mathrm{Mw}$ to $110-\mathrm{Mw}$ with the addition of a new $74-\mathrm{Mw}$ turbine generator. Southwestern Public Service Company (SPS) was selected from the second round CCT solicitation. The SPS project involves the repowering of an existing $250 \mathrm{MW}$ (nominal) steam turbine-generator at the SPS Nichols station Unit 3 in Amarillo, Texas with a Combustion Engineering (CE) CFB. The project represents about a 2 to 1 scaleup of the Texas-New Mexico Power (TNP) 150 MW CE CFB plant currently under construction. The TNP design represents about a 2 to 1 scaleup of the CE CFB at the Scott raper Company in Chescer, Pennsylvania. A third CFB project has recently been added to the list of selected projects under the DOE CCT program. The city of Tallahassee was chosen, as an alternate under Round 1, for repowering their Arvah B. Hopkins Station Unit 2 with a CFB. The boiler vendor had not been identified at the time this report was written.

A major concern of these projects is the performance of the refractory. Many refractory designs, products, and installation methods are currently being used in the industry. This is symptomatic of the uncertainty in the design requirements for this system. CUEA has already experienced refractory problems which have resulted in forced outage time. Several other units are rumored to be experiencing refractory problems and requiring significant outage time to make repairs and modifications. 


\subsection{OBJECTIVE}

The objective of this task was to develop a benchmark as to where the design and selection of refractory materials for use in CFB systems exists today. There are close to 40 operating CFB units in the United States with varying amounts of operating time and experience. Most of these units are small in comparison to the Colorado Ute, SPS, and Tallahassee projects; nevertheless, they operate with similar temperatures and most operate with coal and lime:tone. The objective of this task was carried out by:

- identifying and summarizing refractory problems experienced with operating domestic $\mathrm{CFB}^{\prime} \mathrm{s}$,

- identifying $\mathrm{CFB}^{\prime} s$ that did not experience problems and explaining reasons why as compared to those that did (e.g. design, installation, operating differences, process upsets, etc.),

- providing causes for the problems and recommendations/fixes made to eliminate the refractory problems identified,

- and determining for each $\mathrm{CFB}$ the brand and type of refractory, the installer, method of installation, curing process, and whether the refractory was field or factory installed.

Based on the information gained from this task, general recommendations have been made for the design, installation and operating requirements for future CFB refractory systems. 


\subsection{SCOPE}

To maximize the usefulness of this task in supporting DOE and the Clean Coal Technology program, the survey concentrated on CFB plants which, (1) have an appreciable amount of operating experience and (2) operate on coal (bituminous, subbituminous, anthracite, and coal waste products such as anthracite culm, and gob). Six major vendors were identified: Babcock and Wilcox, Combustion Engineering (Lurgi), Foster Wheeler, Keeler Dorr-Oliver, Pyropower, and Riley Stoker. Tables 1 through 6 list the units which these vendors have operating, under construction, or planned. A total of 31 CFB units was researched. The information contained in this report is based on discussions and information provided by the owners/operators of these units, the boiler vendors, and the refractory vendors. Table 7 is a listing of the type of information that was solicited from these sources. 


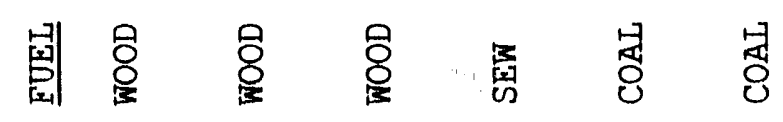

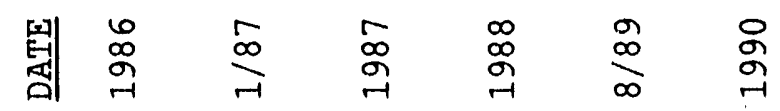

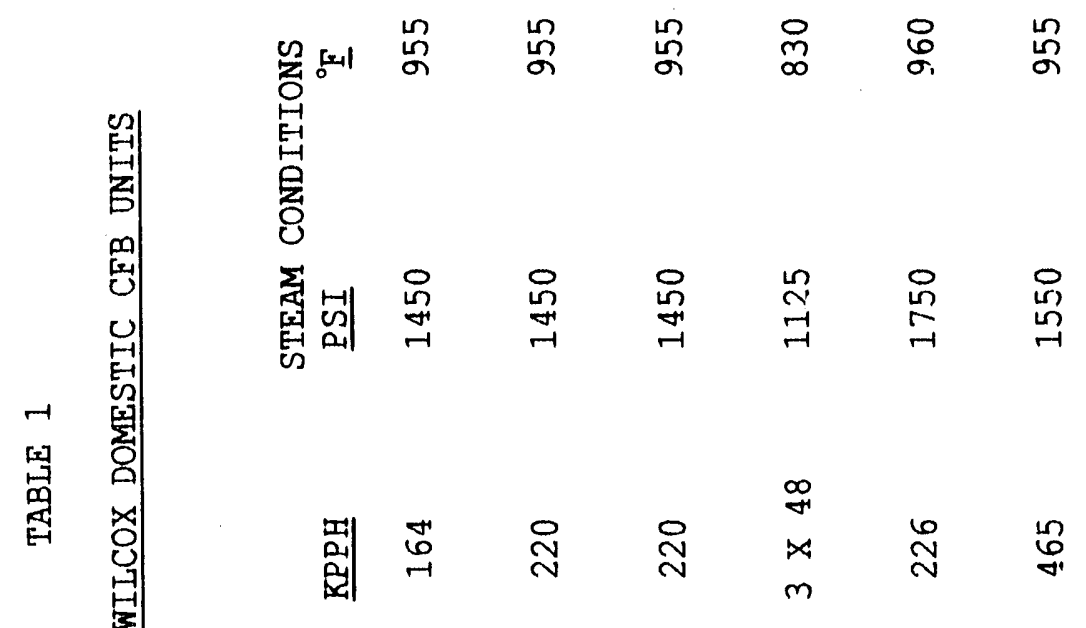

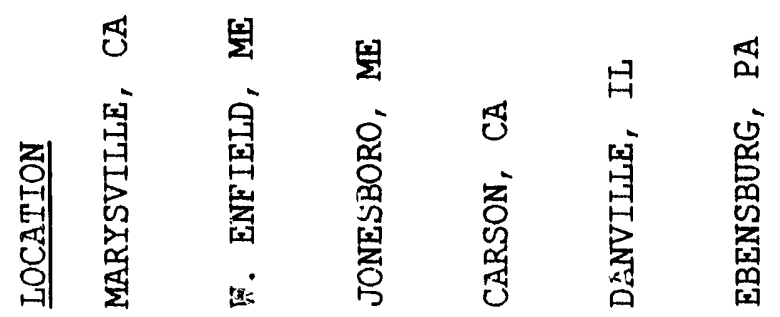

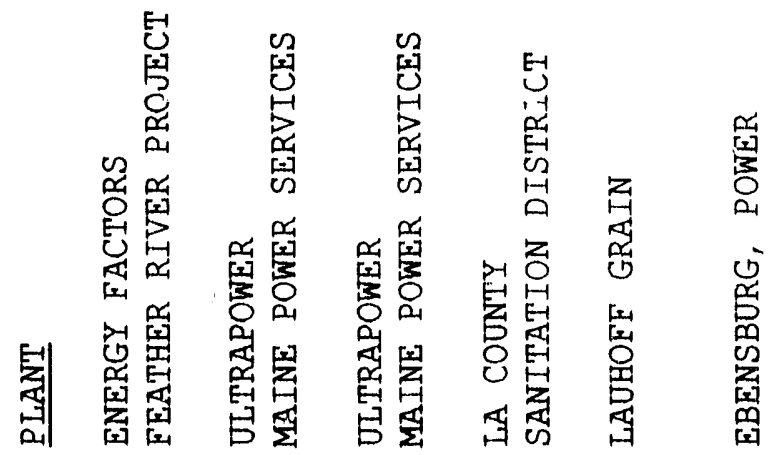




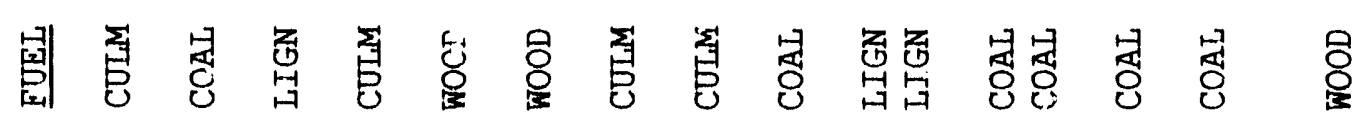

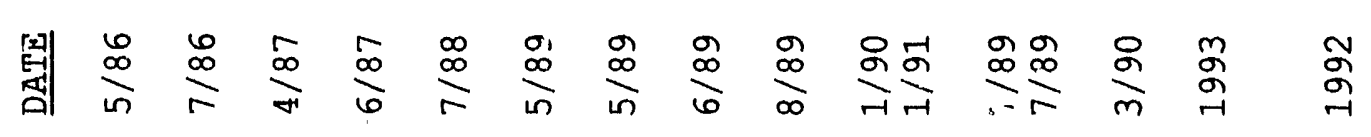

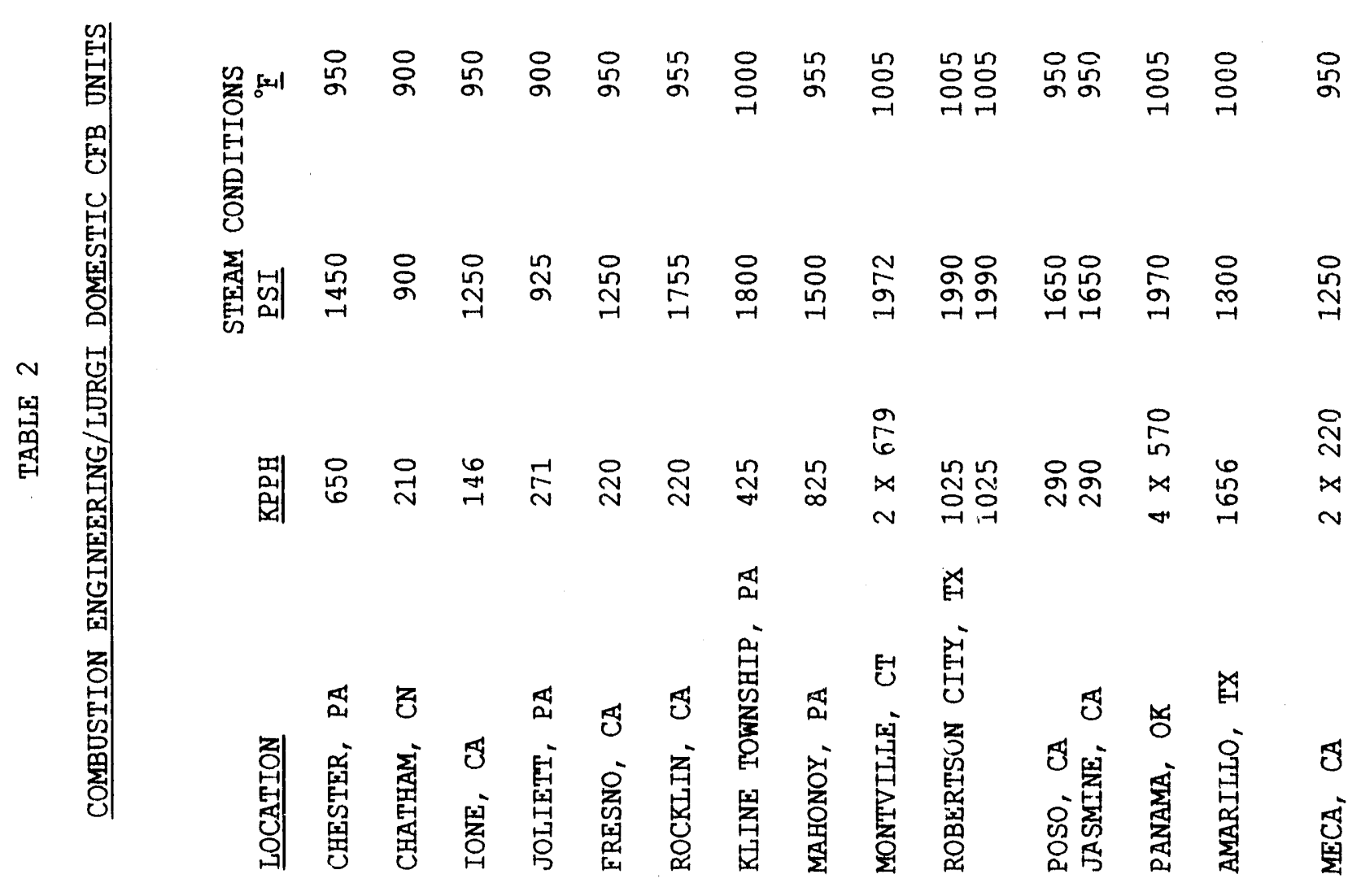

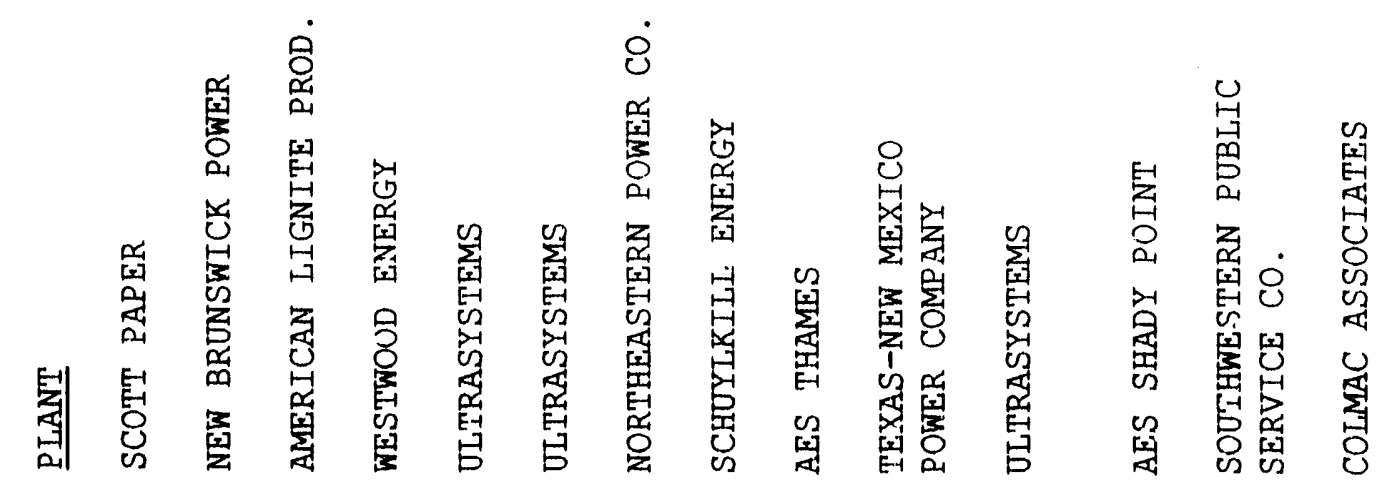




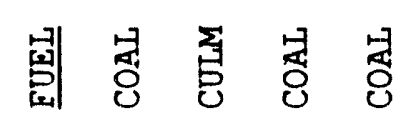

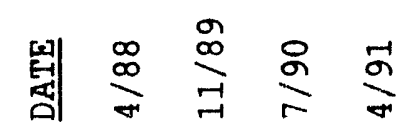

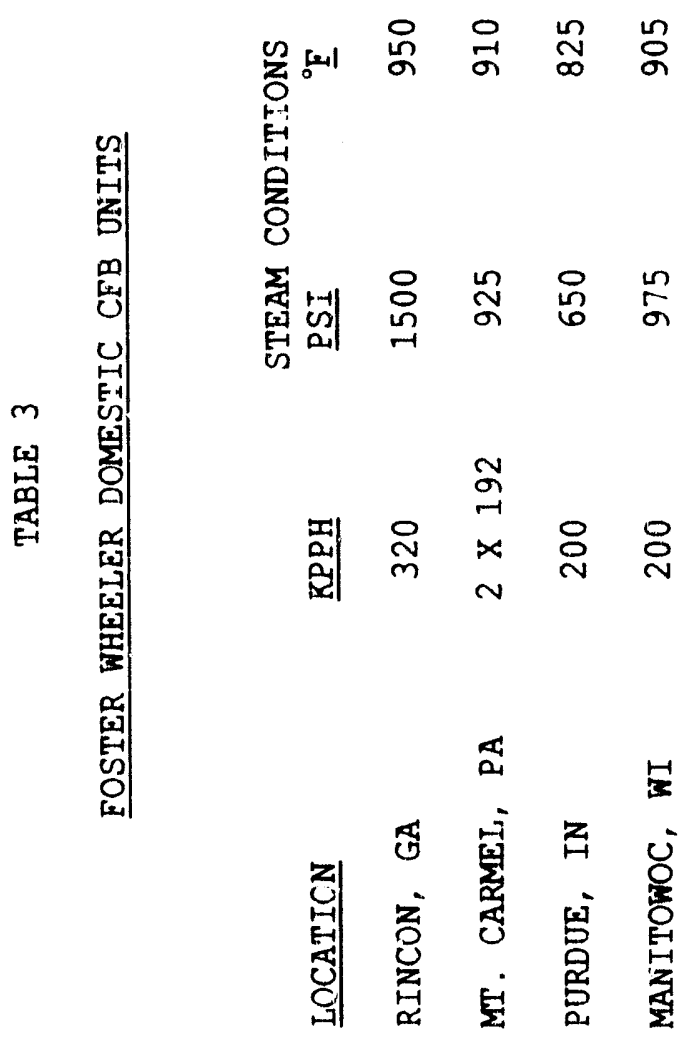

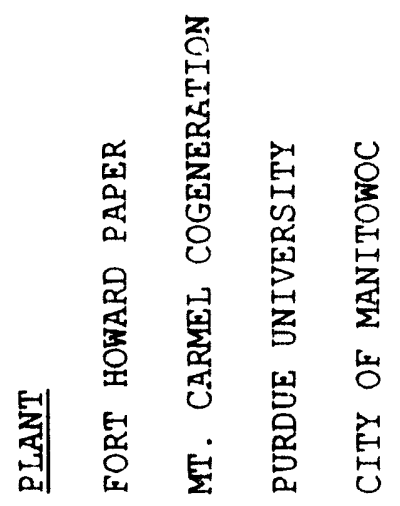




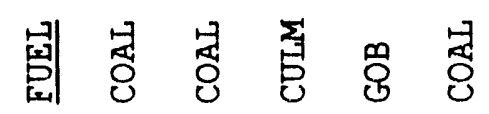

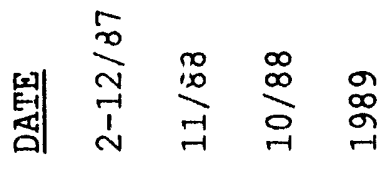
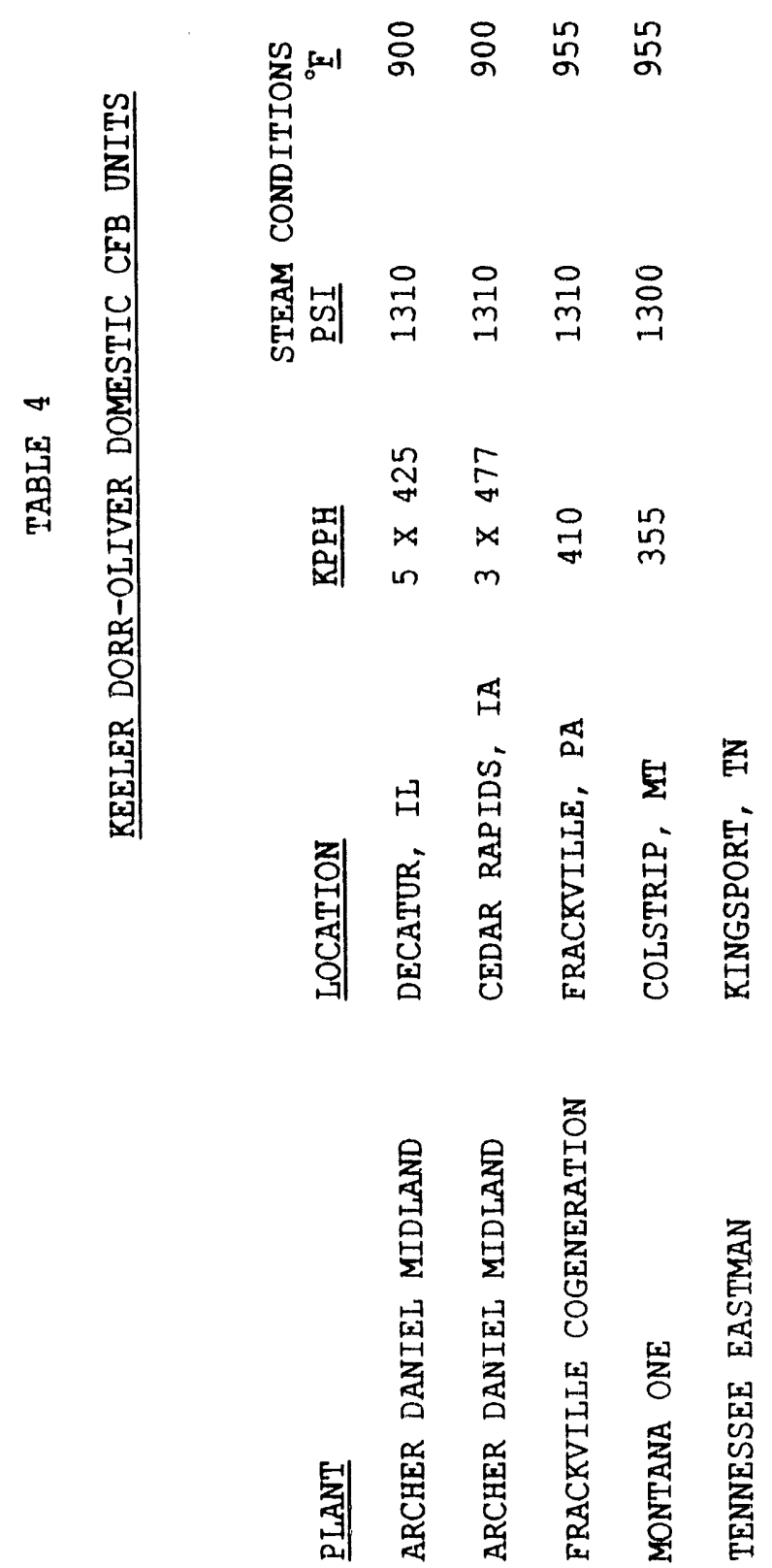


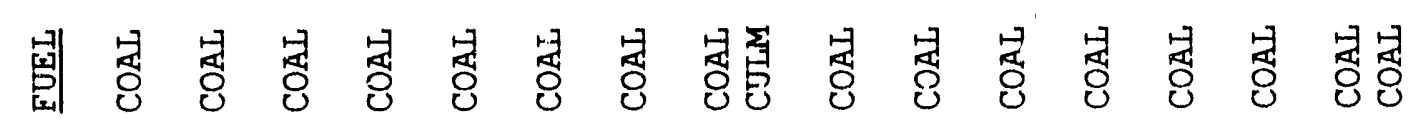

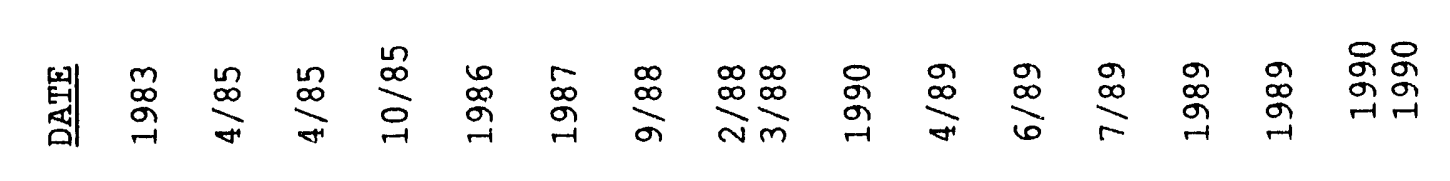

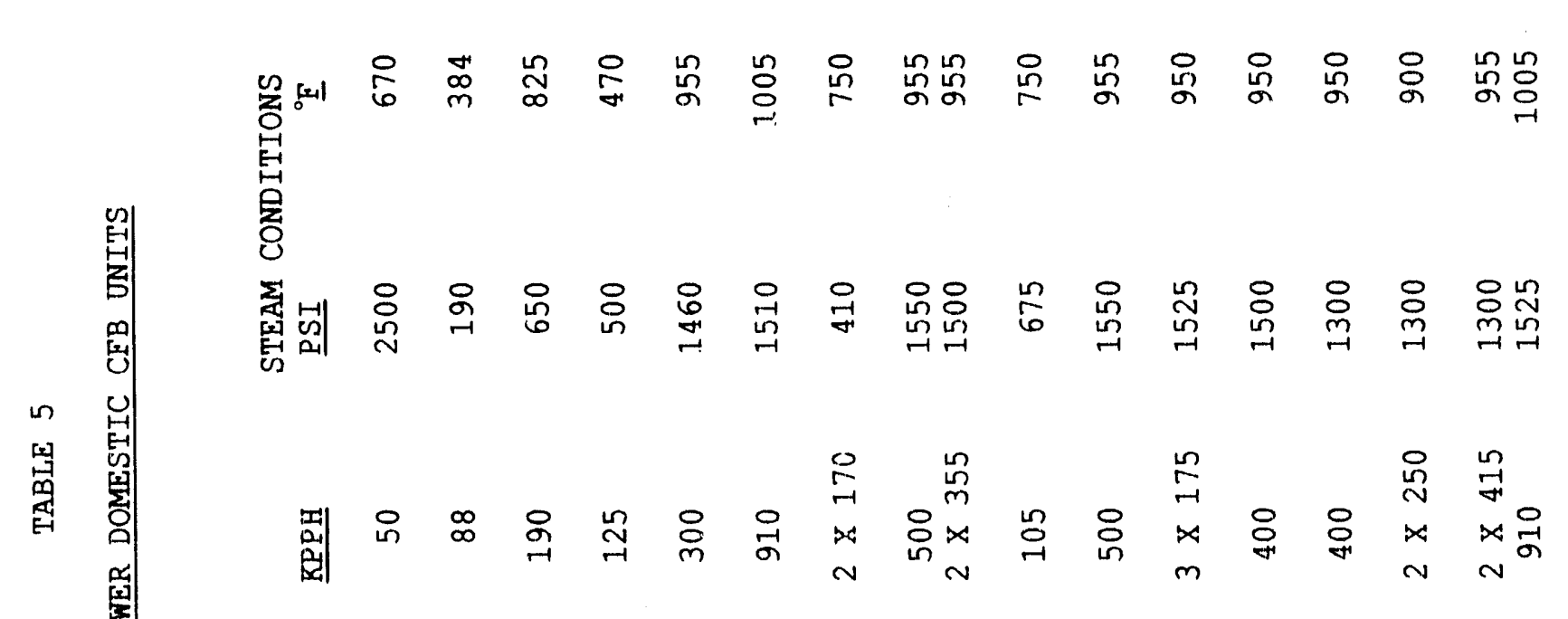

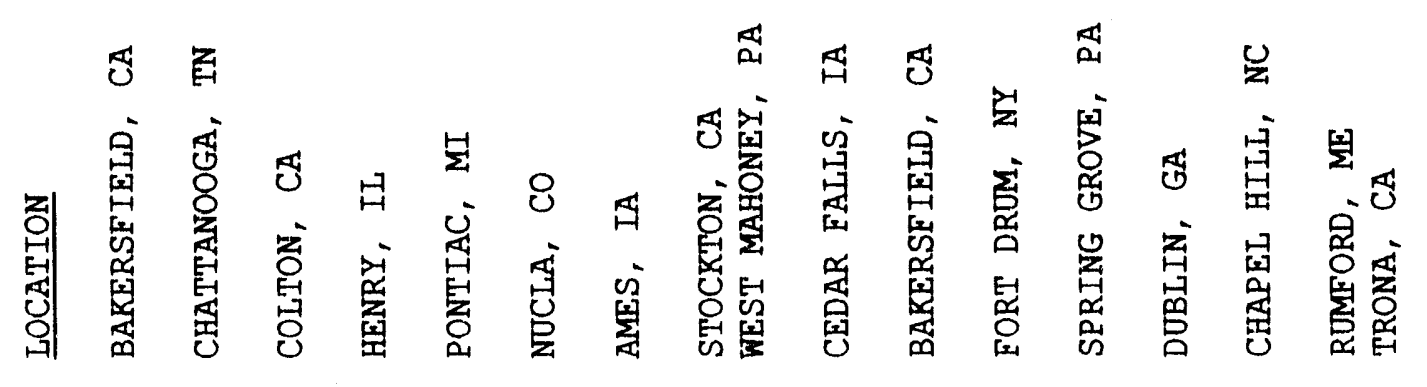

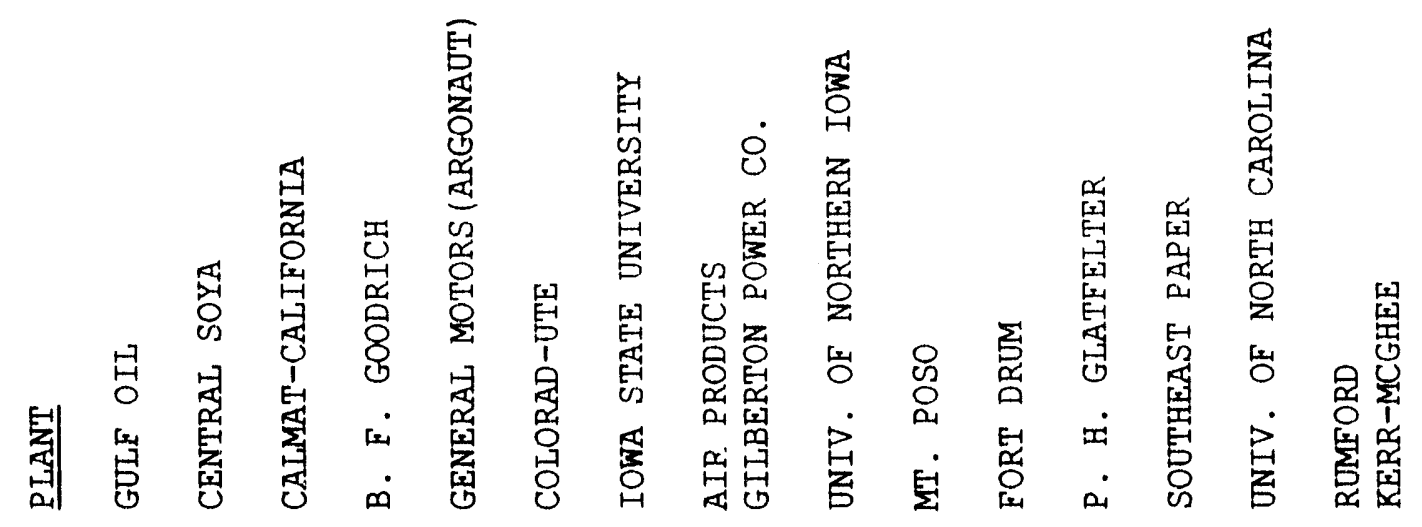




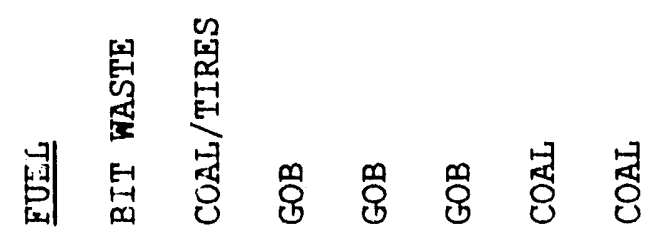

$$
\begin{aligned}
& \text { 圈总总总驾总总总 }
\end{aligned}
$$

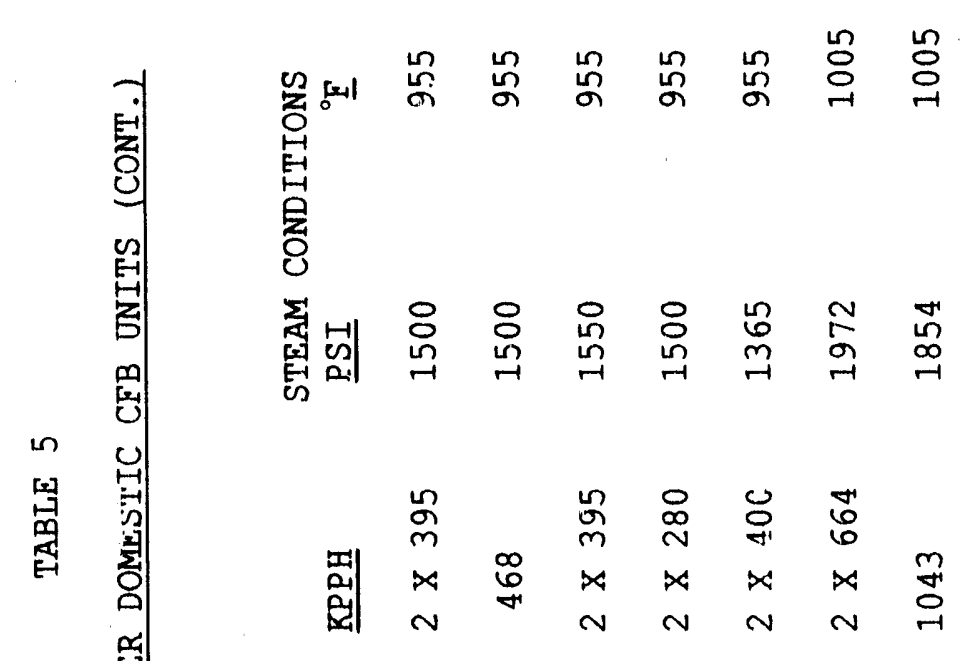

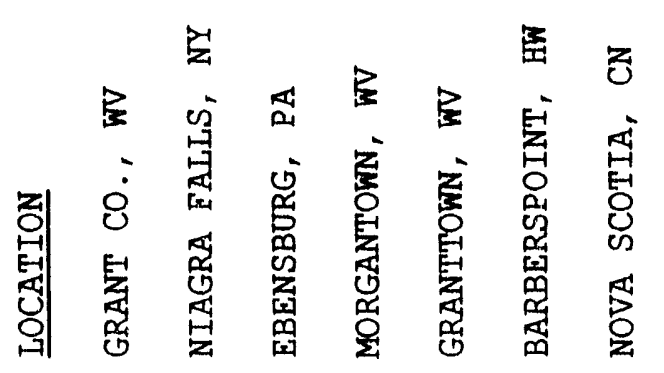

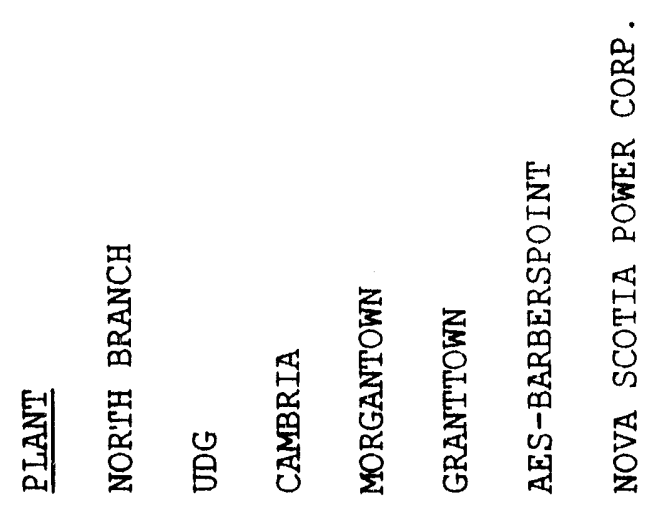




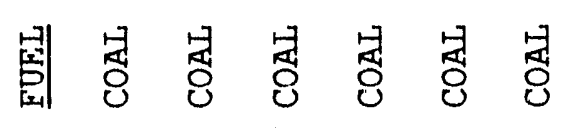

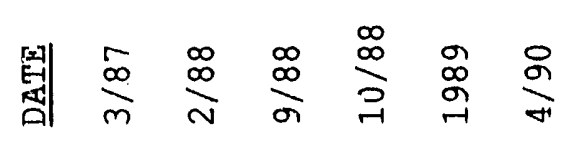

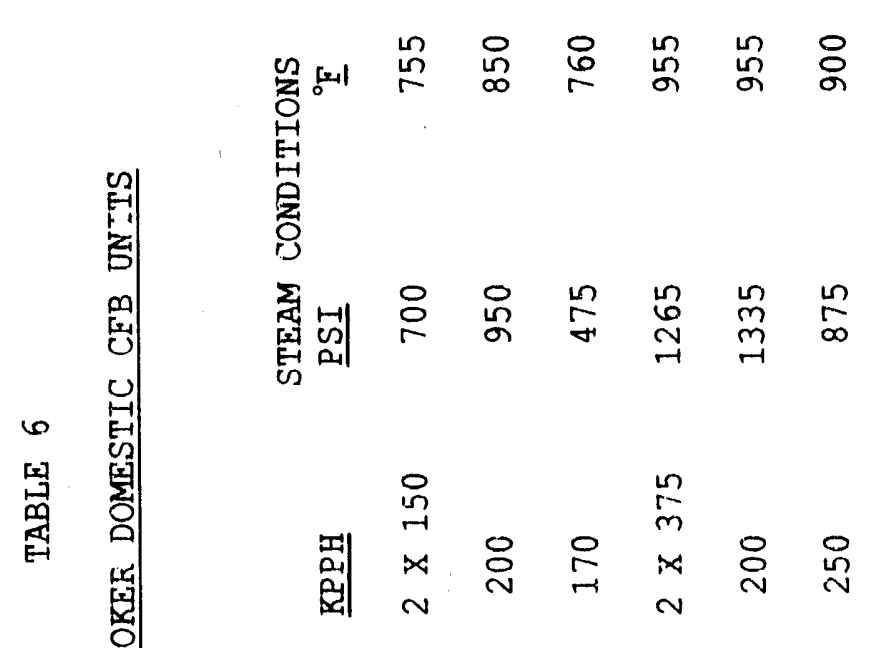

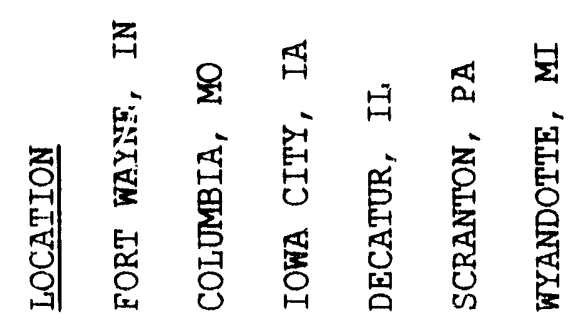

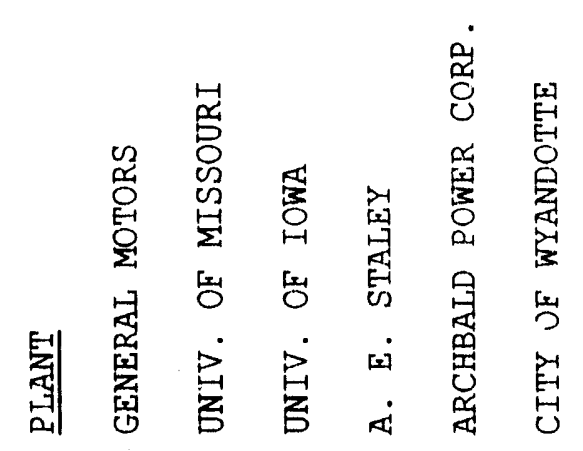


TABLE 7

SURVEY INFORMATION

\section{PLANT INFORMATION}

- $\quad$ SIZE (MW, KPPH, DIMENSIONS)

- FUEL, SORBENT/BED MATERIAL

- BOILER VENDOR

- HOURS OF OPERATION

- OPERATING CONDITIONS (VELOCITY, TEMPERATURE, CYCLING, BASE LOAD, ...)

\section{REFRACTORY INFORMATION}

- $\quad$ BRAND/TYPE

- INSTALLATION METHOD (GUNITE, CAST, RAM, BRICK)

- ANCHOR REQUIREMENTS (TEMPERATURE, TIME)

- PROPERTIES (SHRINKAGE, THERMAL CONDUCTIVITY, ABRASION LOSS, STRENGTH， DENSITY)

- Q.C. E?OGRAM

- $\quad$ COST/SCHEDULE

- THICKNESS

\section{EXPERIENCE}

- WHAT WORKED/WHAT DIDN'T

- $\quad$ PROCESS UPSETS

- $\quad$ RESULTING PROBLEMS

- $\quad$ REPAIRS/FIXES

- SERVICE + TFE

- RECOMMENDATIONS

- annual maintenance cost 


\subsection{CFB DESCRIPTION AND REFRACTORY REQUIREMENTS}

Fluidized-bed combustion of coal in the United States has seen a shift from bubbling bed units to circulating bed units with the potential for better combustion efficiency and lower pollution $\left(\mathrm{SO}_{2}\right.$ and $\left.\mathrm{NO}_{8}\right)$ emissions. Bubbling beds, by design, operate with relatively low velocities (4-12 ft/sec) and low recycle ratios (0-5 lbs recycle/lb coal). At these conditions, the need for refractories is minimal. CFB units, on the other hand, are dependent on reliable refractory service for three primary reasons: (1) combustion and emission performance are dependent on high recycle ratios (typically 40 - 50 lbs of solids recycled per ib of cral fed) which increases the solids loading in the system and thus the erosion/abrasion potential, (2) performance is dependent on higher velocities $(15-30 \mathrm{ft} / \mathrm{sec})$ to entrain and "circulate" the larger amounts of solids which also increases the erosion/abrasion potential, and (3) $\mathrm{CFB}^{\prime} s$ are operated with staged combustion air to improve emissions (primarily $\mathrm{NO}_{x}$ ) which requires that a portion of the unit be operated at substoichiometric conditions. To operate in this manner, CFB's must have refractory designs which protect uncroled surfaces from overheating while minimizing heat loss in the uncooled areas. CFB refractory designs must also protect the components from the high velocity, high dust loading abrasive/erosive environment, and, in addition, the refractory design must also protect metallic components that are located in substoichiometric, reducing environments.

Figures 1 through 6 are typical of thi CFB configurations that are provided by the six boiler vendors. CFB componerts which require refractory include: combustor, cyclone, dip leg or downcomer, loop seal or seal valve, bottom ash cooler (optional), external heat exchanger (optional), and windbox.

Combustors require refractory in the lower section, just above the distributor plate, to protect the combustor walls from the turbulent mixing of fuel, sorbent, and recycle material. One vendor's (Riley Stoker) design also maintains a dense bed of large inert material. The lower region in all CFB's is run substoichiometric and refractories are required to shield the metallic components from this potentially corrosive environment. Depending on the design, the floor of the unit may have a refractory layer. The upper section of the combustors are waterwall lined with refractory used at 


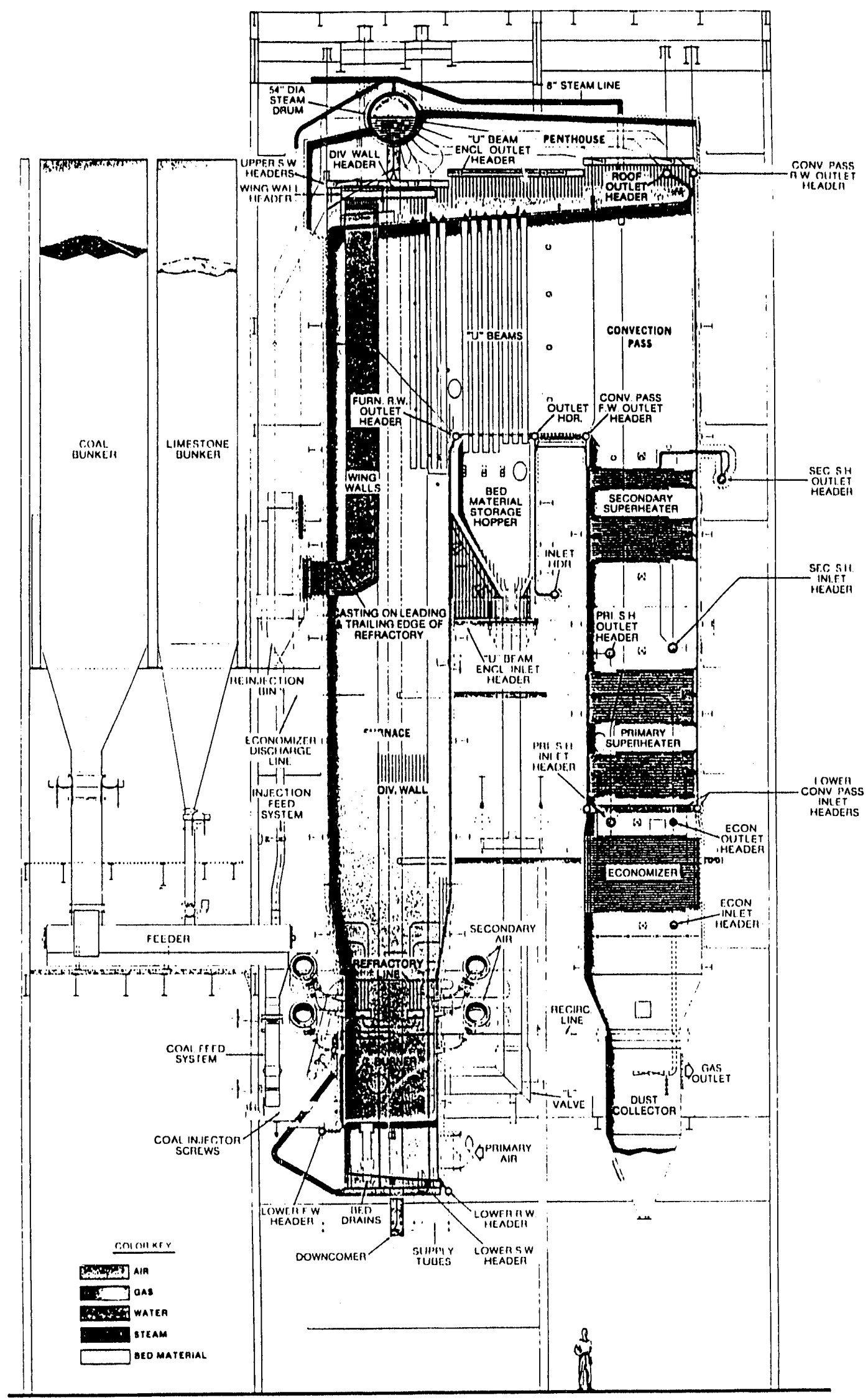

FIGURE 1 - BABCOCK \& WILCOX CONFIGURATION 

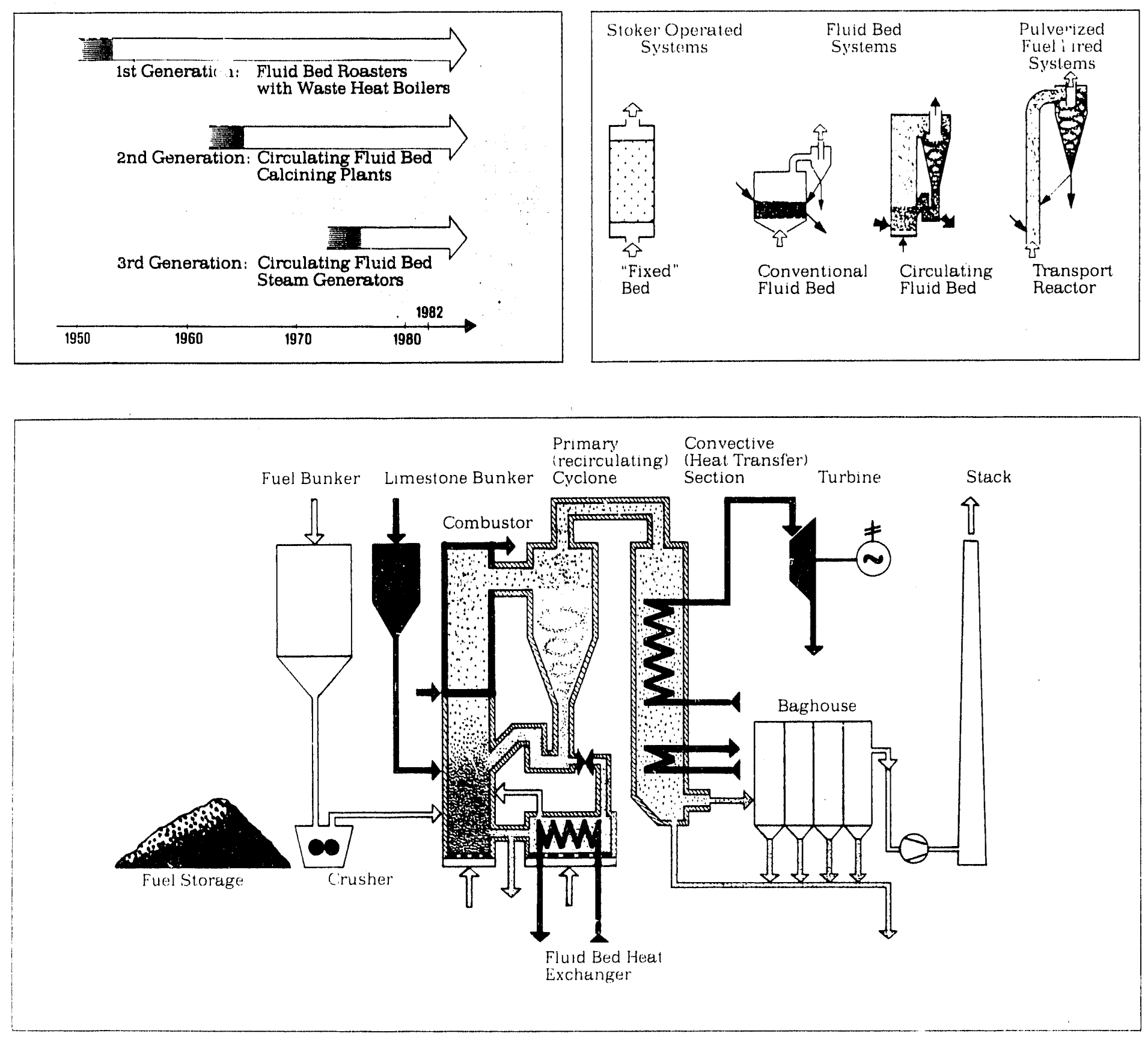

FIGURE 2 - COMBUSTION ENGINEERING CONFIGURATION 


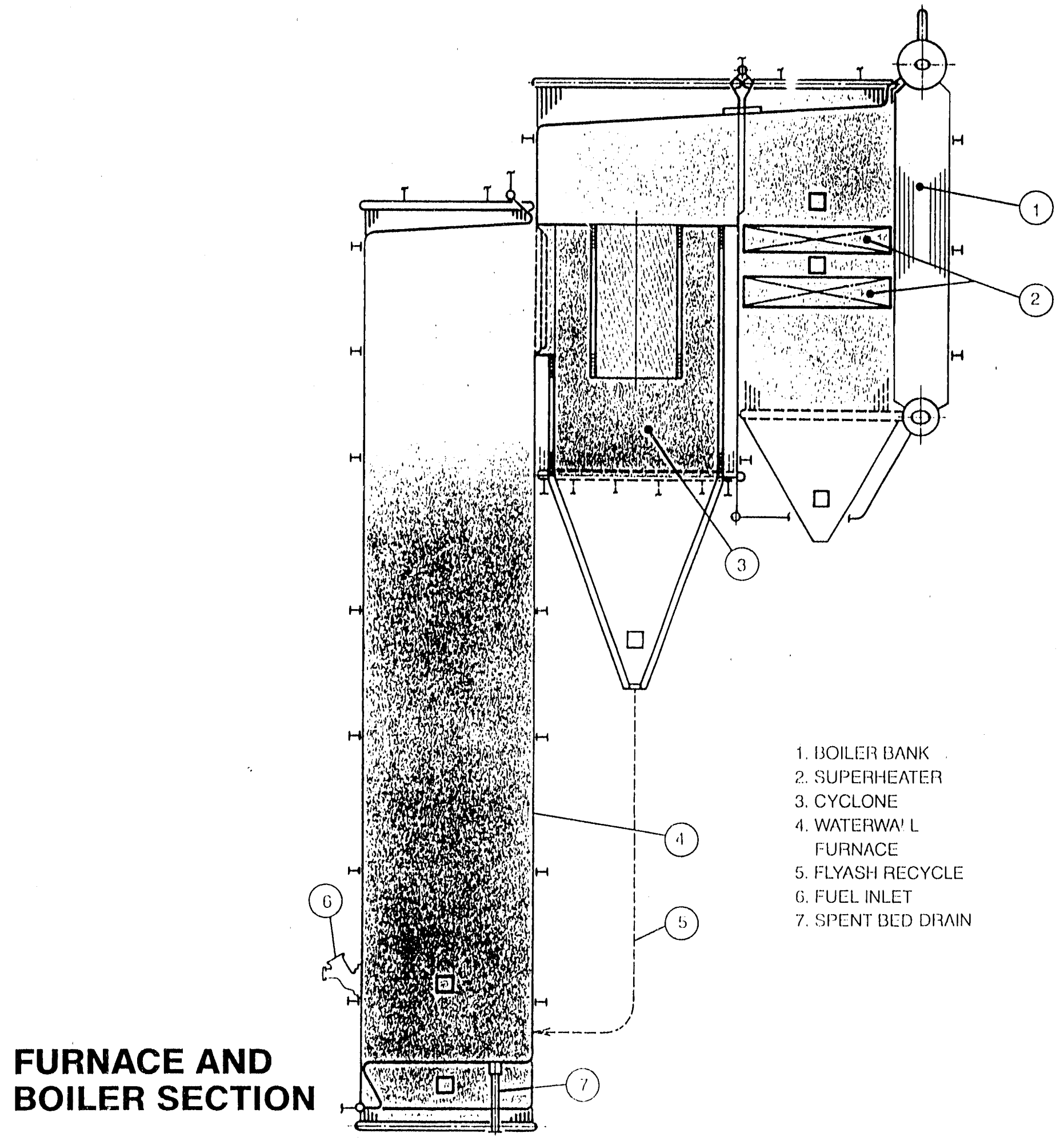

FIGURE 3 - FOSTER WHEELER CONEIGURATION 


\section{Keeler/Dorr-Oliver Model HCFS}

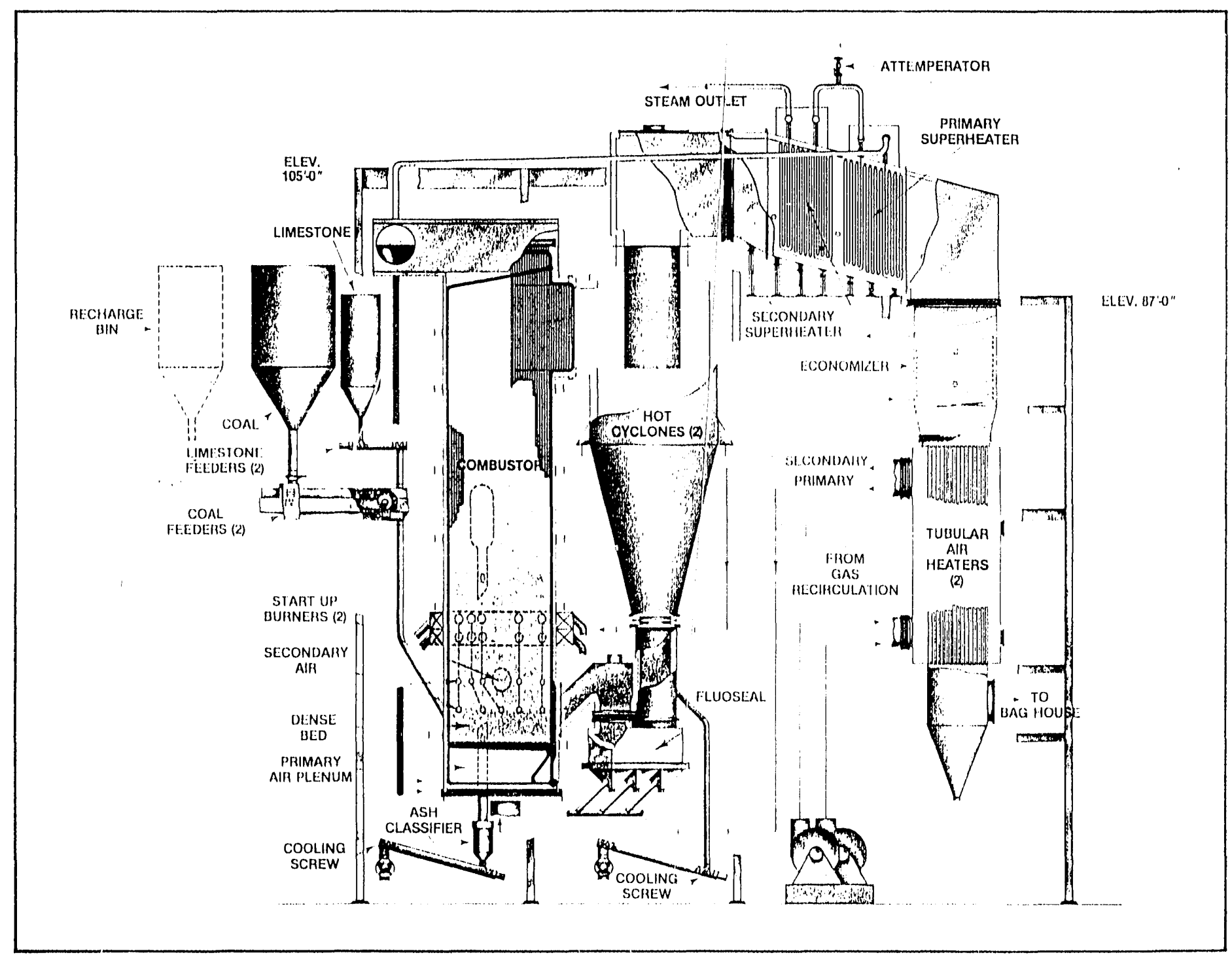

Configuration for high pressure, high-temperature generation

FIGURE 4 - KEELER/DORR-OLIVER CONFIGURATION 


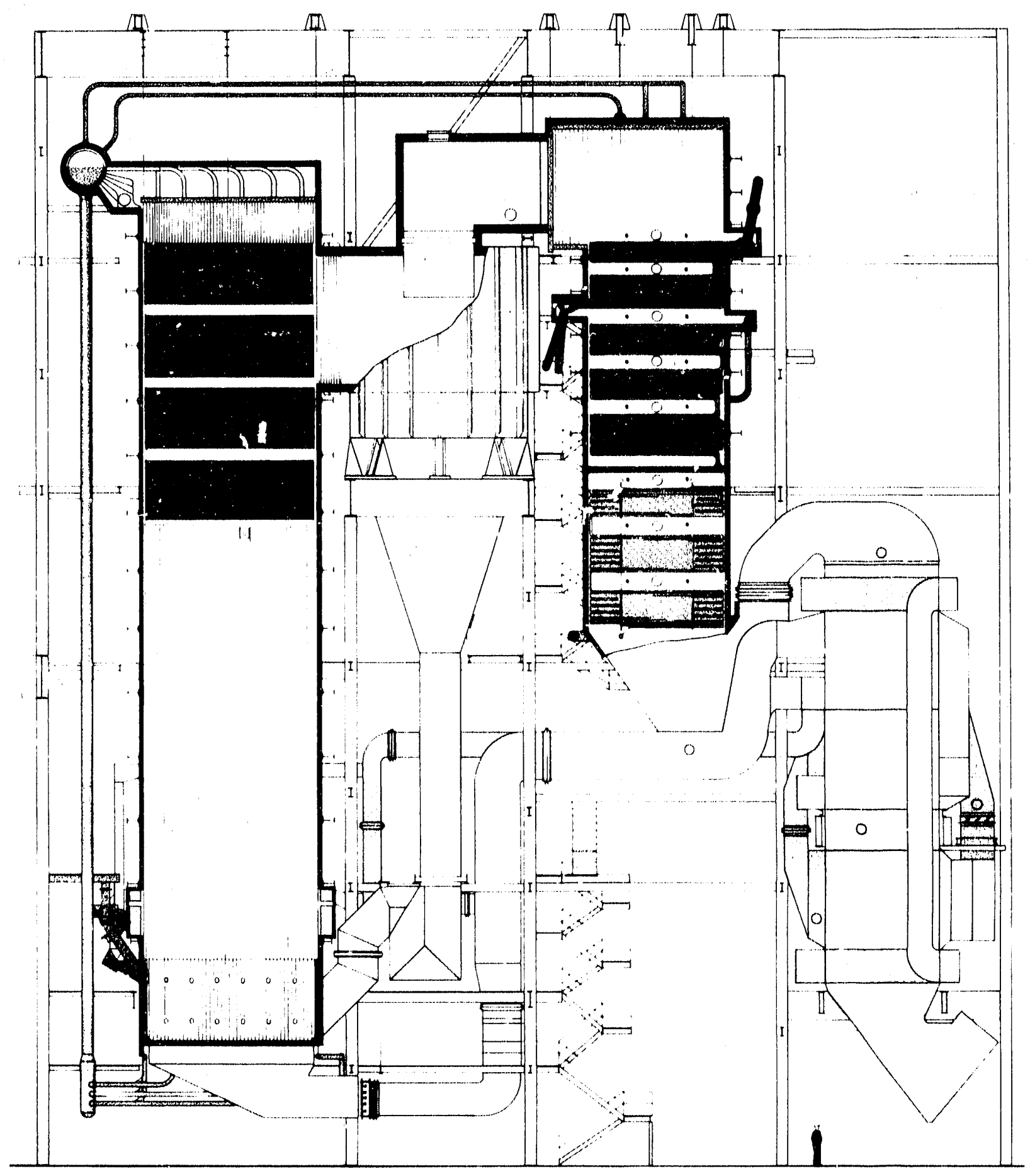

FIGURE 5 - PYROPOWER CONFIGURATION 


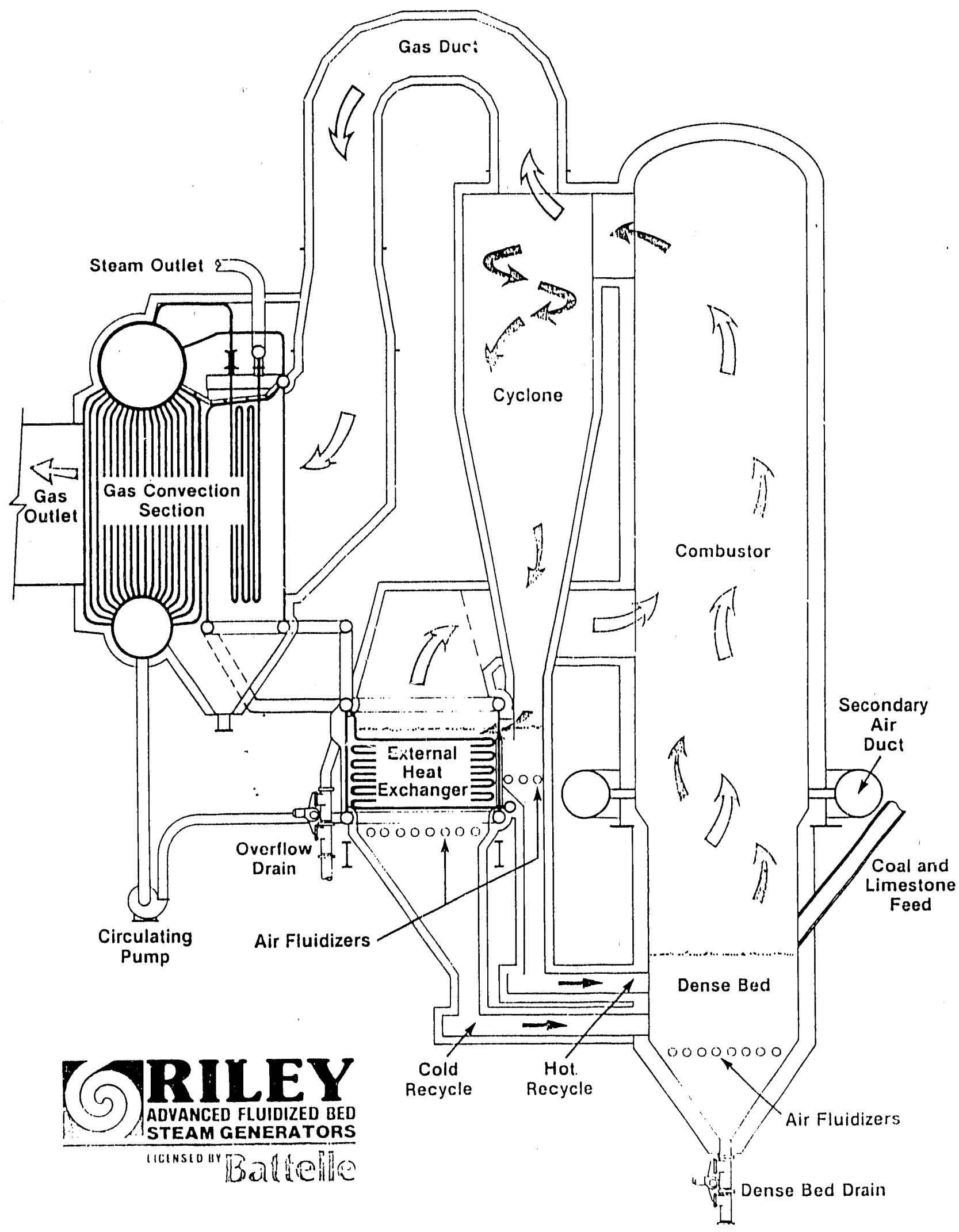

FIGURE 6 - RILEY STOKER CONFIGURATION 
the combustor exit to the cyclone and in some cases the combustor roof as well.

The cyclones operate at high velocities to produce the high collection efficiencies required to maintain high recycle ratios (solids loading). Babcock and Wilcox does not utilize cyclones but rather uses a U-Beam separator, which does not require refractory protection except for the casing around the separator and the collection hopper. The discussion on cyclone refractory experience is divided into the following sections: gas/solids inlet, cyclone barrel and roof, cyclone cone (solids outlet), and cyclone out let (gas outlet). Refractories must withstand high velocities, high dust loadings, and high temperatures. The cyclones provide the severest test for refractories and hence have experienced more problems.

From the solids outlet of the collection device solids travel to the pressure seal device through a dip leg or downcomer. This head of material also assists in providing a pressure seal and the driving force for recycle of solids back to the combustci. Refractory requirements in this region are primarily for insulation purposes. Hard facing is required but velocities are relatively low.

The pressure sealicontro] device acts as the pre. sure seal between the positive pressure in the lower combustor and the negative pressure in the cyclones. Solids are collected from the downcomers and reinjected into the lower combustor. Various types of devices, called by different names, are used including loop seals, J-valves, L-valves, seal pots, and Fluoseals, to name a few. All serve a similar function. These devices are second oniy to the cyclones for experiencing refractory problems. The redirection of the solids requires an acceleration of the material and subjects the seal device to thermal expansion. Several of the seal devices have had failures to the metal casing due to these thermal stresses.

Two of the vendors (Combustion Engineering and Riley Stoker) utilize a separate vessel, referred to as an external heat exchanger (EHE), to perform additional heat duty. The EHE collects solids from the cyclones and flows a portion of this material over evaporator, superheat, and/or reheat surfacing in a 'benign' low velocity bubbling bed. Both vendors also have provisions for directly reinjecting hot solids back to the combustor. Refractory needs in this area are primarily for insulating purposes; however, both vendors use refractory weirs or dam walls in the EHE to separate the EHE into different temperature zones.

To maintain proper solids loading and size distribution, bottom ash is periodically removed from the bottom of the combustor. Many of the vendors utilize a refractory lined vessel to fluidize this drained material. The smaller material is elutriated and carried back into the combustor while the large material is selectively removed and disposed. A portion of the sensible heat is removed from the large material by the fluidiring air and retained in 
the system. Refractory needs in this device are primarily insulating requirements with the ability to handle the fluidized material. Because of the intermittent nature of draining bottom ash, the coolers are subjected to cyclic operation over a wide temperature range.

The primary air to the combustor is brought into a plenum or windbox except for Riley Stoker which uses air sparger pipes. The windbox provides uniform fluidization air, typically from the outlet of an airheater, during normal operation and hot air rrom an induct burner during unit startups. Refractory in this region serves as an insulation barrier and, in general, has not been an area of major concern.

As can be seen, refractories play a vital role in the successful. operation of CFB's. Failure of the refractories to perform properly can result in operation and maintenance problems such as plugged drains, hot spots, defluidization, erosion, abrasion; any of which can bring a unit off-line. 


\subsection{SURVEY RESULTS}

Based on technical discussions with boiler vendors, refractory suppliers, and owner/operators of $\mathrm{CFB}^{\prime} \mathrm{s}$, and review of available technical reports, a summary of refractory system design development for $\mathrm{CFB}^{\prime} \mathrm{s}$ has been collected. The CFB technology has experienced rapid growth and acceptance over the past five years. With this growth, lessons have been learned and products have been developed to improve the design of refractory systems for CFB's. The following sections summarize the findings from discussions with boiler vendors and owner/operators of $\mathrm{CFB}^{\prime} \mathrm{s}$. Appendix A contains irformation obtained from refractory suppliers on products which have been used in CFB's and where they were applied.

\subsection{BOILER VENDORS}

Attempts were made to discuss refractory experience and design development with all six boiler vendors. As can be seen below, some were more willing to ohare information than others. This topic is sensitive as some vendors feel they have a commercial edge over their competitors and are unwilling to discuss the subject. Others are hesitant to discuss details, as they have units which are still under warranty and in some cases are in arbitration with refractory slippliers and installers. Summarized on the following pages are comments received fron. boiler vendors, verbally or through written reports. 


\section{$5.1 .1 \quad$ BABCOCK \& WILCOX}

Babcock \& Wilcox (B\&W) has CFB units at six sites. Three of these are wood fired and one is fired with sewage. The other two units are coal fired, neither of which have started operating yet. Table 1 gives a listing of these units along with their location, steam conditions, and date of commercial operation. The fol'swing information was obtained from discussions with B\&W personnel and refeience 1.

The $B \& W$ units use a thin layer (approximately 1-inch) of high thermal conductivity refractory on the lower walls of the combustor for erosion and corrosion protection. The refractory height was initially 6-1/2-feet from the floor. Later, overfire air ports were installed higher in the combustor with the refractory raised accordingly. The West Enfield refractory was raised to a height of 18 feet, while Jonesboro was raised to 15 feet. Biasing of the overfire air with more being injected through the front wall resulted in wear in the furnace refractory. Where waterwall tubes are bent out of plane to allow for ports, wear also occurs. These areas have bean protected with refractory. The lower combustor is covered with a $82 \%$ silicon carbide refractory with a calcium aluminate hydraulic bord. This material is gunned onto a dense array of $7 / 8$-inch long pin studs. Undulations in the refractory surface, which did not meet flatness or thickness specifications, resulted in uneven wear of the surface. Sheets of refractory $1 / 16$ to $1 / 8$ inch thick spalled off (beyond the ends of the pin studs). It is believed that the gunning material set up too quickly (15-20 minutes) and prevented the surface from being straight-edged smooth. Later refractory installation used a modification of the above gun mix which had a longer set time (45-60 minutes) and resulted in better conformance to the specification for flatness. Later repairs and extensions used a 778 silicon carbide material supplied by another vendor (Harbison-Walker Harbide 80 ). This material has held up extremely well.

In addition to the lower combustor waterwalls, the combustor roof is coated with 2 -inches of gunned 478 alumina $r$-ractory (Kaocrete HSRFT) which contains 2-3\% stainless steel needles. The needles are added to improve the thermal shock, spalling, and abrasion resistance of the refractory. No problems have been noted after 2-1/2-years of operation. Refractory is held in place with $\mathrm{V}$-anchors placed on a staggered pitch.

The $B \& W$ CFB units do not use cyclones, but instead, collect solids via a UBeam mechanical collector. The outer walls, roof, and collection hopper of the U-Beam are refractory lined with an abrasion resistant high-density gunned 568 alumina refractory which incorporates stainless steel needles. This material is a higher grade refractory than the material used for the combustor roof. It was chosen since these areas are somewhat inaccessible. The roof and wall areas have 2 inches of refractory attached with $V$-anchors. No refractory problems have been experienced on these surfaces in 2-1/2 years of 
operation. The collection hopper abrasion resistant refractory has a thick layer of insulating refractory between it and the hopper shell to retain heat. Both layers are held in place with $Y$-anchors. The abrasion resistant refractory disintegrated in six months, exposing the insulating refractory to the abrasive fly ash.

The hoppers were repaired by casting three inches of the same abrasion resistant refractory. This repair looks good at the Jonesboro site, but some cracking due to thermal cycling has occurred at West Enfield. B\&W has made design changes to their CFB for future units by using waterwall membrane panels to form the hoppers. This eliminates the need for dual layer refractory in this area. The hoppers are now designed for 4-inches of abrasion resistant refractory anchored directly to the panels. This design is used at the Lauhoff Grain CFB. V. J. Mattson installed the refractory at this plant. 


\section{1 .2 COMBUSTION ENGINEERING}

Combustion Engineering has five CFB units which have appreciable operating time and thirteen additional units which have either recently started up or will be in operation within the next year or so. Fuels used in these units include bituminous, anthracite culm, lignite, and wood. Combustion Engineering classifies these units into three designs. The first generation units have straight combustor walls which consist of upper sections of waterwall membranes and lower walls of refractory lined plate. The Scott Paper and New Brunswick units have this design. The second generation units are characterized by combustors with straight walls which are made ntirely of waterwall membrane construction. Units with this configuration are the Ione and Westwood plants. The third and current design configuration has tapered lower walls and use waterwall membrane construction for all the walls, floor, and plenum. The Fresno and following units have this design. As these design changes were made, refractory changes were being made as well. The following is based on discussions with Combustion Engineering personnel and reference 2.

The early first generation units with the lower portion of the combustor uncooled required two layers of refractory, 16-20 inches thick. The high density, abrasion resistant, hot face refractory was gunned onto anchors with expansion gaps approximately every two feet. These gaps filled with bed ash during operation which caused pinch spalling during heatup. This situation was made worse by numerous startups and shutdowns. Cracking and loss of refractory around large combustor ports occurred even on sevond generation units. Sp. ..ed refractory caused problems by plugging bed drains and bottom ash conveyo: s. Spalled areas were repaired using phosphate bonded plastic refractory.

The later second and third generation units which have fusion welded waterwalls require only a thin abrasion resistant refractory lining. Thin linings minimize thermal spalling by having only small temperature gradients through the material. Pre-fired silicon carbide tiles, 6 inches $x 6$ inches which are formed to the waterwall contour, are currently being used and are showing good strength and abrasion resistance characteristics. These tile are attached to the walls by pins and mortar. Silicon carbide possesses a high heat transfer coefficient $\left(100-120\right.$ Btu-in./hr. $\left.\mathrm{ft}^{2} \mathrm{~F}\right)$ which allows lower waterwalls to be heat transfer effective and at the same time minimize thermal spalling of the refractory due to large temperature gradients. Silicon carbide also has excellent erosion/abrasion resistance. The Fresno unit has seen excellent service from silicon carbide tile in the lower combustor.

The cyclones used with the early combustor designs were equipped with the same refractory construction as the lower section of the combustors. The cyclones saw the same type of problems with pinch spalling occurring, especially in the lower cone area. The cyclone barrel section saw refractory loss due to erosion in the target zone (area where particles impact from the high velocity 
tangential cyclone entry). Patching was required. The solution to these problems has been the replacement of the gunned abrasion resistant refractory with brick. Brick was installed in the cone section of two units and the barrel section of another unit. After over a year of service, the brick in these units looks excellent. Combustion Engineering's current cyclone refractory design calls for abrasion resistant brick in the cyclone barrel and cone sections. Multiple layers of insulating blocks of calcium silicate are used to provide the required skin temperature. Work is continuing on identifying materials which possess better wear resistarne for use in the target zone.

Original loop seal and downcomer refractory designs were similar to the gunned installation used in the original lower combustors and cyclones. As to be expected, they saw the same type of problems as mentioned above. The design of the refractory for these components has evolved into the use of plastic and fused silica castable refractories. These materials have been in use for over a year with excellent results. 


\section{1 .3 FOSTER WHEELER}

Foster wheeler has one CFB in operation and two units under construction. The Foster wheeler design differs from other CFB's in that it uses a water/steam cooled cyclone. This allows a much simpler, thinner refractory lining. Cooled cyclones are covered with only 2-4 inches of refractory compared to 1216 inches of dual layer refractory for uncooled cyclones. Skin temperatures are much lower for the cooled cyclones as well. The refractory, typically 2 inches of Blue Ram plastic with stainless steel needles, is shop installed on closely spaced steel studs. This refractory covers the entire surface except for the seams where the different sections of the cyclone are welded together in the field. These joints are then covered with the same material. If the client requests it, abrasion-resistant tiles of Blue Ram can be placed as an. inner protective liner. Refractory dryout and heat curing of the shop applied material is done during a furnace stress relieving cycle at $1250-1275 \mathrm{~F}$. Dryout and heat curing in the field are performed by filling the water circuit and firing the in-duct burner normally.

Wear in the cyclones is low angle abrasion except for erosion which may be occurring on the target zone. The standard test for evaluating abrasion (ASTM c704) does not do a good job at duplicating cyclone service conditions: velocities are uncertain, tests use high velocities at high angles, conventional erodent is suspect, and loadings are typically low. Foster Wheeler has developed a low-angle impingement test rig which better evaluates the relative abrasion characteristics of refractory materials and CFB particulutes. Results from this rig show that some castables and plastics benefit from being heated, with significantly better abrasion resistance developed at temperature. Of the materials tested, a phosphate bonded 908 alumina trowel mix and a $60 \%$ alumina plastic gave the best high temperature abrasion performance. Gunited materials are not erosion resistant and should not be used for this application. Test results showed that cool startup particulate can he considerably more abrasive than hot recycle material. This may be a result of wearing bare metal versus a metal oxide and/or a softening of the particulate matter with temperature. Less refractory is required at the cyclone gas out let die to the lower abrasion severity brought about by the reduced dust loading and reduced particle size. 


\section{1 .4 KELER DORR-OLIVER}

Keeler Dorr-0liver has $9 \mathrm{CFB}$ units in operation with two more planned. These units are listed in Table 4. The lower combustor membrane walls are refractory lined to protect them from the turbulent, substoichiometric bed environment. Silicon carbide cast and tile blocks are now used in the combustors. The elevation of this refractory has been raised with time as wear was experienced on the waterwall at this interface. The roof of the combustors was originally unlined and btgan to suffer tube failures in a matter of a few hundred hours. This area was repaired by adding a thin layer of silicon carbide refractory. The cyclones and loop seals (Fluoseal) are brick lined in the newer units. The loop seals in earlier units caused problems primarily due to improper expansion joints. Brick linings are more expensive to use but they provide allowance for expansion. Because of the thick refractory requirements for the cyclones and loop seals, cold startups require approximately 15 hours with heatup rates of $100 \mathrm{~F} / \mathrm{hr}$. Cyclones should not be gunited due to the severe service, i.e., high particle loadings and high velocities. This service requires brick. If the coal ash is highly alkaline, the use of silicon carbide based materials will result in chemical attack of porous surfaces, characteristic of gunited acid based refractories. The formation of glass phase reaction products in these pores can build up stresses, eventually leading to peeling of the refractory. A successful refractory design is dependent on using proper materials with the proper technique for installation. 


\section{1 .5 PYROPOWER}

Pyropower has 25 CFB units which are either in operation or will be by 1990 . These units are all coal fired with one burning anthracite culm and another gob. Table 5 is a listing of these units, describing plant, location, steam conditions, fuel, and date of commercial operation.

Pyropower has formed their own refractory subsidiary, Pyropower Energy Services Company (PESCO). Pyropower feels they have developed, over the past 14 months, a refractory system that gives them a competitive advantage. Pyropower declined to discuss their refractory experience or philosophy. PESCO is not interested in performing reiractory work for any non-Pyropower jobs. PESCO did state that future Pyropower units would use brick in the cyclones and loop seals. 


\section{1 .6 RILEY STOKER}

Riley Stoker has seven CFB units in operation and one under construction as shown in Table 6 . These units, which all burn coal, use the MultisolidsFluidized-Bed-Combustion (MSFBC) concept licensed by Battelle. The design uses larger feed stocks and rocks to form a dense bed in the lower section of the combustor. The early concept involved completely refractory lined combustors which decoupled combustion and heat transfer and provided fuel flexibility. There wasn't a large demand for fuel flexibility and the use of fully refractory lined combustors was not cost competitive, primarily due to the additional material and installation costs. For these reasons, Riley stoker switched to a combustor with the lower section refractory lined and the upper section having waterwall heat transfer surface.

Riley stoker doeg not have a refractory division which required them to go outside for a refractory supplier and installer. The initial position was to have the refractory supplier be responsible for the installation as well. This limited the number of responses for Riley's early units to a few suppliers (Plibrico, CE, and A. P. Green). However, this did provide for a tighter designed refractory system with better warranty provisions. The only warranty available from the refractory manufacturers today is "our materials are what we say they are." Riley stoker is currently in arbitration with one refractory supplier and is involved in discussions over technical differences with another. Riley currently splits the contract for refractory materials and installation.

Initial information on refractories (primarily from the petroleum industry) was very limited. What was known was that shell temperatures should be kept below $350 \mathrm{~F}$. Higher temperatures would cause differential expansion between the shell and refractory and would break the anchors. Riley stoker feels that development work needs to be performed to allow shell temperatures to be increased to 650 - $700 \mathrm{~F}$. This would result in lower capital and maintenance costs as hundreds of tons of refractory could be eliminated. Foundation loads would be decreased and structural steel costs would be lowered. Today, however, no suppliers are comfortable at designing anchor systems for these higher temperatures. Offsetting this would be the requirement for additional external insulation to minimize heat losses. Reliable methods would be needed to detect hidden hotspots. The other specification that was given was the refractory should have an abrasion loss of around $10 \mathrm{CC}$ (ASTM C704 test). What resulted from these specifications was a two or three layer system. Riley Stoker opted for the two layer system which consisted of a six to nine inch layer of gunned insulating refractory next to the wall with a four to six inch layer of hard facing. Y-anchors on six to twelve inch centers, depending on refractory thickness, was the preferred anchor design. Early experience with thick hot cyclone refractory showed that two inch $x$ two inch screen ("road mesh") caused refractory to fail in shear at the screen. All suppliers recommended y-anchors. 
One Riley Stoker site has suffered a very large number of refractory failureo in the lower combustor. Large pieces of refractory have broken loose and interfered with the local fluidization. Sections have become defluidized, causing clinkers to form which in turn took the unit offline. Large cracks formed in the upper combustor caused overheating of the combustor casing. Six to eight months of operation at this site saw one-third of the hard facing worn off at the cyclone inlet. The cone section experienced major cracking with large pieces falling out. Sections of the walls of the external heat exchanger (EHE) fell off. Recycle lift lines (lines for recycle back to the upper section of the combustor) saw no cracking but within two months of operation, the refractory was worn to the bare carbon steel. Riley stoker is in arbitration with this supplier (Plibrico) regarding use of improper materials and poor installation. Over half of the original refractory $(6000$ $\mathrm{ft}^{3}$ of hard facing) has been replaced at this site.

Riley switched to a different refractory material supplier and installer (A. P. Green) for the next unit. Cracks were noted on this unit, but much less than seen at the site described above. Problems were experienced with EHE bricked dam walls. This design was replaced with a monolithic casting with proper expansion joints. Over vibrating can cause the aggregate and'binder to separate. Cracks are more prone to start near combustor penetrations which do not have proper anchors. Riley stoker has not reported any corrosion on any of their units, but they have noticed some discoloration of the refractory.

Another Riley Stoker unit suffered a major failure in the lower combustor when one wall of the combustor suffered anchor failures. The failures occurred between the insulating and hard face refractories causing the wall to crack and pull away from the side of the combustor. The refractory didn't fall in but had to be chipped out and replaced. The original hard face refractory, Ultra-Green 45 (an ultra-low cement vibrating castable) was replaced with Greengun 83P (a gunned phosphate bonded high alumina plastic). George P. Reintjes, the original installer, made the repairs. Repair patches at other Riley Stoker units show that phosphate bonded plastics are performing better than low cement castables. Rammed plastic is labor intensive to install but with the development of gunned plastics this would be Riley Stokers recommended refractory today.

Results from early units showed that modifications were needed to improve combustion efficiency. These modifications were implemented where possible on units that were already under construction. One change that was made was to go to smaller reducing zones and larger oxidizing zones. To implement this on units under construction required reducing refractory thicknesses. These changes raised shell. temperatures up from $140 \mathrm{~F}$ to $240 \mathrm{~F}$, still well below the $350 \mathrm{~F}$ maximum limit.

The dam walls in the Riley Stoker EHE have suffered failures with monolithic and brick designs. These problems have been resolved by the use of monolithic 
cast walls with proper expansion joints. Lift lines have seen some high local wear due to local flow disturbances. Design changes should eliminate these problems. 


\subsection{CFB OWNER/OPERATOR}

CFB sites supplied by the six boller vendors were identified and contacts were made with 31 of these units. The survey concentrated on units which had operated for a sufficient amount of time to be able to gather meaningful results. The survey also was directed toward coal fired units as this task is in surport of the DOE Clean Coal Technology program. Experience varied from "no prcblem" to "refractories have a major impact on availability." Operating time for these units ranged from 0 to 25,000 hours.

Many of the people interviewed were quite knowledgeable about the refractory design and experience for their units; however there was also a lack of refractory knowledge by some of the operators. Refractory systems typically have been a low priority issue to the customer during the plant design review and construction phase. The level of knowledge is somewhat indicative of the amount of refractory problems experienced. Material types, brand names (original and replacement), and installer names are given for many of the units. In those instances where this information is not given, it is usually due to the lack of refractory knowledge by the plant personnel quizzed and not due to a refusal on their part to share information. However, some owner/operators were reluctant to discuss their refractory experience because of warranty issues that were still pending or a desire to retain a commercial advantage over their competitors who might use this technology. Coments received from the owner/operators and information obtained on thest units from written reports are summarized on the following pages. 


\section{2 .1 NEW BRUNSWICK POWER}

New Brunswick Power operates a $210 \mathrm{kpph}$ Combustion Engineering CFB in Chatham, Canada. The unit began operation in June of 1986 and has accumulated approximately 4500 hours of operation. Steam conditions for the unit are 850 psi and $900 \mathrm{~F}$.

\section{Combustor}

The combustor cross section is roughly 12-feet $\mathrm{x} 12$-feet with approximately the first 20 feet of the combustor walls refractory lined. Since this portion of the walls is not constructed of waterwalls, the refractory is composed of a dual layer of eight inches of insulating and eight inches of abrasion resistant refractory. Velocity in this region is on the order of 11-12 $\mathrm{ft} / \mathrm{sec}$. Castable material used in this area had problems essentially immediately. Since startup, there have been five or six occasions where major repairs were required. On these occasions, one or more walls of the combustor have been stripped back to the walls and studs. Minor repairs have been made with some success using a rammable material which was used at Georgetown and Summerside (Combustion Engineering (now Premier) "Red Ram"). Spalled pieces of refractory tended to cause operating problems by plugging drains. The unit has experienced some slagging, but corrosion does not appear to be a problem. Cyclic operation may have been partly to blame for the spalling experienced. Some problems, such as ash getting behind the refractory around ports, were due to improper installation. Bricks were installed above the fuel chute arch and have worked well. They have only seen minor damage in 3000 hours of exposure.

The remainder of the refractory in the unit (cyclones, downcomer, loop seals) has performed with essentially no problems. The external heat exchanger which has refractory lined floor, roof, walls, and weirs, experienced minor problems with a section of the roof refractory collapsing. This most likely was due to poor installation. All the refractory in the unit was installed in the field except for some piping that was delivered lined. 


\section{2 .2 AMERICAN LIGNITE PRODUCTS}

The American Lignite Products plant in Ione, California has a Combustion Engineering CFB that produces $146 \mathrm{kpph}$ of steam from lignite and lignite waste. The lignite has high silica ash with a lot of rocks. The CFB began operation in February of $198 \%$ and, except for the first few months, has been operated at $75 \%$ availability. Steam conditions from the CFB are 1250 psi and $950 \mathrm{~F}$.

\section{Combustor}

The combustor utilizes waterwalls the full length of the unit with the lower portion of the walls covered with an abrasion resistant refractory. This material was installed 6 inches thick originally. It began to crack and suffer some snzlling, but was still considered serviceable. North American Refractories Guncrete, a low iron abrasion resistant gun mix, was used. Initially there was too much refractory on the walls and some of it had to be removed to get the proper amount of heat transfer. In April of 1989, the combustor refractory was replaced with silicon carbide tile, except around the burner throat.

\section{Cyclone}

The cyclone began operation with 8 inches of insulating refractory next to the shell with 6 inches of abrasion resistant refractory (North American Refractory 'Guncrete') between the insulating refractory and gas strean. Rapid erosion was experienced in the cyclone at the target zone iuirect impingement point of dust laden gas stream in the barrel of the cyclone). Repairs were made in this area by patching with NIKE 50AR. Later, brick material was tried in the cyclone, but was found to be sensitive to "calcium attack". Corrosion products permeated the surface with a resulting change in color of the bricks noted. The cyclone ended up with corrosion/erosion wear. Currently, the bricks have been replaced with a phosphate bonded chrome alumina material (North American Alchrome 85P). This material has been installed for about 18 months with site staff estimating a two-year service life. Chrome bearing refractories pose a disposal problem since they are classified as a hazardous waste.

Although there has been some cracking of the refractory in the downcomer and recycle loop, these materials have not had to be touched. The ash cooler refractory was cast and has seen some spalling, especially on the line to the cooler. Because of the intermittent use of the ash cooler, it is subjected to a lot of cyclic operation between $1500 \mathrm{~F}$ and $200 \mathrm{~F}$.

The unit was designed to handle and remove large material, but still gets 
plugs due to 4-5 inch pieces of refractory which spall occasionally. The installation of screens over the drain points has helped.

The owner stated that because of the significant number of repairs that are required, refractories could be a major cost item. 


\subsubsection{WESTWOOD ENERGY}

Westwood Energy operates a 271 kpph Combustion Engineering CFB at Joliett, Pennsylvania. Steam conditions are $925 \mathrm{psi}$ and $900 \mathrm{~F}$. Operation of the unit began in June of 1987 and has approximately 17 months of service. The unit does not have a fluid bed external heat exchanger but does have a fluid bed ash cooler. Operating temperature for the combustor is approximately $1800 \mathrm{~F}$, using anthracite refuse with limestone addition.

\section{Combustor}

The combustor is composed of a waterwall designed enclosure with a cross sectional area of approximately 14 feet $x 14$ feet. The first 25 feet or so of the waterwall from the distritutor plate up is refractory lined. This area is covered with approximately a 3-inch thick layer of high density abrasion resistant material for corrosion and erosion protection. The combustor has seen localized spalling of the refractory but no major repairs have been required. A test panel of silicon carbide refractory material has been installed in the wall for evaluation.

\section{Cyclone}

All the uncooled system components (cyclone, seal pot, fluid bed ash cooler) use a dual layer of refractory, a low-density insulating refractory next to the metal casing and a high-density abrasion resistant refractory on the gas side. The original material was a field installed gunited castable. Spalling and erosion problems were experienced in the cyciones. The original material was replaced with brick which has been performing well for the last year and a half. The inlet to the cyclone has had to be repaired, with Combustion Enqineering (now Premier) "Blue Ram" rammable plastic utilized. Only minor repairs have been required in the bed material ash cooler. 


\section{2 .4 SCOTT PAPER}

Scott Paper operates a Combustion Engineering CFB at its Chester, Pennsylvania plant. The unit produces $650 \mathrm{kpph}$ of steam at $1450 \mathrm{psi}$ and $950 \mathrm{~F}$. The fuel burned at the plant is an anthracite culm. Operation of the Scott Paper CFB began in June of 1986.

The staff at Scott Paper declined sharing their operating experience with refractories. The reason stated was that Combustion Engineering is still involved in resolving refractory concerns. Scott Paper is representative of Combustion Engineering's first generation CFB. Generic comments on this design are discussed under Combustion Engineering's writeup. 


\section{2 .5 FORT HOWARD PAPER}

Fort Howard Paper Company operates a Foster wheeler CFB at its plant in Rincon, Georgia. The CFB produces $320 \mathrm{kpph}$ of steam at $1500 \mathrm{psi}$ and $950 \mathrm{~F}$. The unit began operation in February of 1988 and reached full load in April 1988, and has been at full load the past six months. The unit has burned coal and petroleum coke.

The staff at Fort Howard Paper stated that the unit has not had any refractory problems. The combustor lower waterwalls were coated with air setting A. P. Green AA22 refractory applied to 3/4 inch stud anchors. In May of 1988 a portion of this refractory was removed to increase the heat absorption to the waterwalls with the studs left exposed. The upper portion of the combustor consists of a radiant superheater which is incorporated into the front wall and roof. These are coated with a 1/2-inch thick high conductivity abrasion resistant refractory (AA22). This same material was used to coat the cyclone inlet area. To improve cyclone collection efficiency, the inlet width was reduced by two feet with the addition of a refractory plug made from Combustion Engineering (now Premier) Blue Ram material. The cyclone is constructed of waterwall panels and therefore only requires a thin coat of abrasion resistant refractory. The cyclone barrel has approximately two inches of Blue Ram plastic refractory which is covered by Blue Ram tile with a 1/4-inch gap between tiles. The cone section has a vibration cast fused silica refractory lining. The loop seal/downcomer region has a dual layer of refractory made up of 5 inches of insulating refractory and 4 inches of vibration cast fused silica. The loop seal roof was gunited and has seen some wear. J. T. Thorpe Company was the refractory installer. 


\section{2 .6 FRACKVILLE COGENERATION}

The Signal Energy's Frackville Cogeneration plant in Frackville, Pennsy? vania operates a Keeler-Dorr Oliver CFB rated at $410 \mathrm{kpph}$. Steam conditions for this plant are $1310 \mathrm{psi}$ and $955 \mathrm{~F}$. The plant started up in October of 1988 and uses anthracite culm as the fuel.

Problems with turbine trips have resulted in numerous thermal cycles. Erosion has been noted in the cyclones, but the main refractory problem has been in the loop seal ("Fluoseal") which was gunited. The combustor uses a single refractory layer of abrasion resistant material. The outlet and cone sections of the cyclone are brick (sliper duty and high duty brick on gas side and light weight insulating refractory next to the shell). The spalling of refractory has caused some pluggage problems. 


\section{2 .7 ARCHER DANIEL MIDLAND}

Archer Daniel Midland operates eight Keeler-Dorr Oliver CFB units at two plants. The Decatur, Illinois plant has five units, each of which produces $425 \mathrm{kpph}$ of steam at $1310 \mathrm{psi}$ and $900 \mathrm{~F}$. The first of these units began operation in February of 1987 and the last one in December of 1987 . Average availability of these units has been around $85 \%$. The other three units are at the Cedar Rapids, Iowa plant. These units each produce $477 \mathrm{kpph}$ of stearn at $1310 \mathrm{psi}$ and $900 \mathrm{~F}$. They began operation in November of 1988 and have approximately 5000 hours of service.

The Archer Daniel Midland staff at the Decatur facility stated that their company had invested heavily in the development and advancement of their CFB units. Because of this vested interest, they declined discussing their experience with refractories. They did, however, have one of their refractory suppliers (Norton) provide some information (see Appendix A). The Decatur facility uses Norton LC904, a calcium aluminate bonded silicon carbide castable.

The Cedar Rapids units use Norton LC904 and CN183, a silicon nitride bonded silicon carbide. The CN183 refractory is used in tube block shapes. The Cedar Rapids units benefited from the refractory lessons learned at the Decatur units. There have been some refractory problems in the loop seal (Fluoseal) region. The cyclones are brick lined and have not been a problem. The cast silicon carbide refractory was added to higher elevations in the combustor to combat abrasion. 


\section{2 .8 COLORADO-UTE}

Colorado-Ute Electric Association operates a $910 \mathrm{kpph}$ Pyropower CFB at Nucla, Colorado. The unit produces $110 \mathrm{MW}$ with steam conditions of 1510 psi and 1005 F. Operations began during the summer of 1987. Total operating time through January 1989 was approximately 5500 hours. Refractory experience for this unit was obtained from discussions with site personnel and abstracted from reference 3 and 4 . The majority of the discussion centers around a major refractory outage that occurred in January-February 1989.

Periodic problems with refractory failures have plagued the Nucla CFB. Several factors are thought to have led to this experience. Low refractory $\mathrm{mix}$ temperatures are believed to have resulted in poor workability of the original refractory. This led to increased water usage which reduced refractory properties and resulted in high shrinkage. Poorly cleaned surfaces may also have contributed to the refractory performance reported. The use of a "top-down" guniting application resulted in rebound and other debris collecting on the walls which can lead to poor bond strength. One other factor that caused spalling problems was improperly prepared construction joints. These joints should have been $90^{\circ}$ to the refractory surface. Shallow angles allowed material to collect in the construction joints which in turn caused triangular pieces of refractory to break off and cause operating problems such as pluggage and nozzle erosion. Improper curing (dehydration) of the refractory at the joints may also have been a contributing factor to failures. Finally, the numerous startups and shutdowns over this time period ( 24 cold starts in 1988 alone), no doubt, played a part in the performance of the refractory.

\section{Combustor}

The lower combustor refractory shows signs of widespread cracking. The majority of these cracks propagate from the combustor openings (feed ports, air ports, bottom ash cooler ports, startup burners) with crack widths varying from 1/4-inch to 1-inch. Spalled refractory and bed material build up was noted in the larger cracks. This material was "layered and hard-packed" indicating that it had been deposited in the cracks over time and been under compressive loads. Periodic inspections, including visual observations and photographs, indicate that some of the cracks are growing in width with time. It is believed that this crack growth is due to the thermal cycling of the combustor. During startup, the unit is fluidized causing bed material to be deposited in the cracks which are at their widest openings in the cold condition. As the unit and refractory come up in temperature, the refractory expands and causes the cracks to close. Any material which was deposited in the cracks in the cold condition is compacted as the cracks close. This scenario is repeated each time the unit is brought up to temperature and later cooled back down. As mentioned above, the materials deposited in the cracks 
build up and take a layered, compressed form.

Compressed bed materials can exert tremendous forces during thermal cycling. Bubbling fluidized bed combustors have experienced failure of in-bed tube supports due to compaction of bed material in crevices between tube supports and tubes. Cyclic operation of the combustors can cause a ratcheting of the tube supports to the point where welds which hold the supports together are broken. Similarly, the material in a CFB can be deposited in refractory cracks to the point where cracks are expanded and finally result in pinch spalling of the refractory.

Areas of refractory spalling in the combustor were somewhat random. Larger areas where spalling has been noted include: lower sections of walls, below manway in one combustor, to left of loop seal return in both combustors, and at the top of the refractory interface with the waterwall in one combustor. Spalled areas were repaired in both combustors using Thermal Ceramics Mix 228G reinforced with stainless steel fibers. Some areas were repaired by hand troweling and others by a gunned application.

Erosion of the refractory in the combustor has keen minor with most of it occurring in the region near the corner primary air lower injection nozzles. The discharge from these nozzles, due to their orientation, impinges directly onto the adjacent refractory. Some erosion was also found below the coal and limestone feed ports which has reached a steady state condition. By proper care in designing the discharge from these nozzles and ports, erosion can be reduced so that it is not a concern at this unit.

\section{Cyclone}

The cyclones have a dual layer refractory lining, initially consisting of 7inches of insulating material (NARCO Litecrete 20) with 5-inches of abrasion resistant material (NARCO Guncrete). The performance of the refractory varied with location. Results are discussed for each section of the cyclones (inlet, barrel, cone, and outlet).

The inlet and barrel roof around the vortex finder was in good shape with little erosion and essentially no cracking. More wear and cracking was noticed on the vertical walls of the barrel section. The refractory in this area was originally installed in four separate sections above the cone, with horizontal cold joints between each section. These joints with time filled with dense-layered bed material, similar to that described for the combustor. The widths of these joints were enlarged due to pinch spalling and erosion.

Refractory at the upper section of the bullnose in one cyclone had cracked completely through, causing the outer steel shell to discolor due to overheating. The bullnose is the interface area between the cyclone inlet duct and the trailing edge of the cyclone barrel. Thermal expansion forced 
the free end of the refractory toward the inlet expansion joint and away from the bullnose. To provide lateral restraint to this movement, expansion stops have been added. These stops are a series of steel plates $(3 / 4$-inch thick $x$ 30-inches long $x$ 8-inches wide) with three gusset plates welded to them and the steel cyclone shell. They extend from the ledge of the inlet to the roof of the cyclone barrel. Two stops were installed in each cyclone barrel; one stop is located in the barrel ten feet downstream of the inlet expansion joint and the other stop is located in the barrel, one foot from the bullnose.

Testing will confirm whether these stops restrain the lateral movement and increase refractory life.

The floor of the cyclone inlet extends into the barrel of the cyclone, forming a ledge which tapers to blend in with the barrel approximately $180^{\circ}$ around the cyclone. The abrasion resistant refractory on the outer corner of the ledge had several loose or broken pieces. These were replaced during the January 1989 refractory repair outage. Both layers of refractory were removed as required and a new anchor design was installed. Seven inches of Thermal Ceramics Kaolite 1800 insulating refractory and five inches of Thermal Ceramics 228G with approximately 1-inch long $304 \mathrm{ss}$ needles were gunned on in this area.

Refractory anchors were removed and replaced with a new design during the January 1989 outage. The original anchors were the "long-horn" or "V" design made from 3/8-inch diameter stainless steel rod material configured to be 8inches long $x 1$-inch wide at the base $x$-inches wide at the tip. The anchors were attached with 1/2-inch threaded stainless steel studs welded to the fireside of the steel shell. The new anchors are made in two pieces: (1) a stainless steel rod stud extension which attaches to the existing studs on the shell at one end and provides a 3/8-inch male thread on the other end, and (2) $a \mathrm{~V}$ assembly which attaches to the rod extension. The $V$ piece is made from 1/4-inch diameter stainless steel rod material, measuring 4-inches long $x$ 1inch wide at the base $x$ 4-1/2-inches at the tip. The insulating refractory is applied up to the base of the $V$ assembly. The $V$ assembly is then encased in the abrasion resistant refractory.

The growth of cracks in the refractory was noticed in the cyclone barrel and cone also. As discussed above, this growth is believed to be due to the thermal cycling and ingress of bed/recycle material. The cyclones, by design, introduce large quantities of solids to the walls (and cracks). As this material packs into crevices, the refractory weakens locally and is easily eroded/abraded by the high velocity dust laden gas stream. Some of the cracks in the cone section approached 4-inches in width. Three large vertical cracks were noted in each cyclone, extending from the base of the cone up to the horizontal refractory support ring at the base of the cyclone barrel section. The cracks were evenly spaced around the circumference of the cones. Several cracks had been repaired in the April 1988 time period with a plastic ram refractory material. It also was noted to have suffered cracking and spalling. The insulating refractory was exposed in some areas as was a number 
of the refractory anchors. During numerous outages, large sections of refractory have been found lodged in the loop seals. The cone section appears to be more prone to packing of recycle material in the refractory cracks than the vertical walls of the barrel due to the gravitational forces that are at work. The new abrasion resistant layer of refractory was installed with special care to minimize the number of cold joints.

The cyclone gas outlet section were found to be in good condition. The general cracking, erosion, and spalling problems seen in the combustor and other areas of the cyclone were not present in the outlets. The dust that did collect in the cold joint of the refractory was not hard packed but could be easily removed with finger pressure. With collection efficiencies in the high $90^{\prime} \mathrm{s}$, the outlet section is subjected to much lower solids loading.

\section{Downcomers/Loop Seals}

During a boiler walkdown on January 5, 1989, a hot spot was noticed on the loop seal casing due to the failure of the loop stal refractory. An orderly shutdown was immediately begun to minimize damage. Once down, the loop seals were opened and the cast arches of both loop seals were found to have failed. Cracking and erosion were widespread with sections of broken refractory laying in the bottom of the loop seals along with broken anchors. Approximately one wheelbarrow full of loose refractory was removed from each loop seal. A heavy concentration of stainless needles were noted at one failure area. The loop seal discharge leg to the combustor showed signs of cracking; however, the refractory was sound and has not been a problem.

After removal of the loop seal refractory in January 1989, several cracks were found in the steel shells. The area near where the hot spot had been noticed was discolored (dark red oxide) and was experiencing scaling. A detailed inspection of the fireside of the downcomers was not possible due to limited access. However, widespread cracking could be seen.

Prior to the hot spot failure which occurred in early January 1989, the boiler vendor (Pyropower) had already decided that the loop seal arch should be replaced and was part of the planned workscope for the 1989 refractory repair outage. Work planned included replacing refractory in the loop seal arches, lower 8 feet of the downcomers, and in the loop seal up-leg (bottom of loop seal to top of discharge leg to combustor).

The originally installed loop seal refractory was a combination of cast and gunned material. Because of the continued failures in this area, this material was replaced with a combination cast, gunned, and firebrick refractories. Figure 7 shows the locations where the now materials were placed. The cast and abrasion resistant gunned material used was Thermal Ceramics Mix 228G. The firebrick used were National Refractories Jay Bee S 
fireclay brick.

The downcomer region between the cyclone cone outlet and the top of the new loop seal firebricks was examined by the boiler vendor and loose sections of refractory were removed and abrasion resistant gunned material applied to make these areas flush with the original refractory (approximately 40 o rework).

Site personnel feel the refractory repairs are superior (materials and workmanship) to those originally installed. 


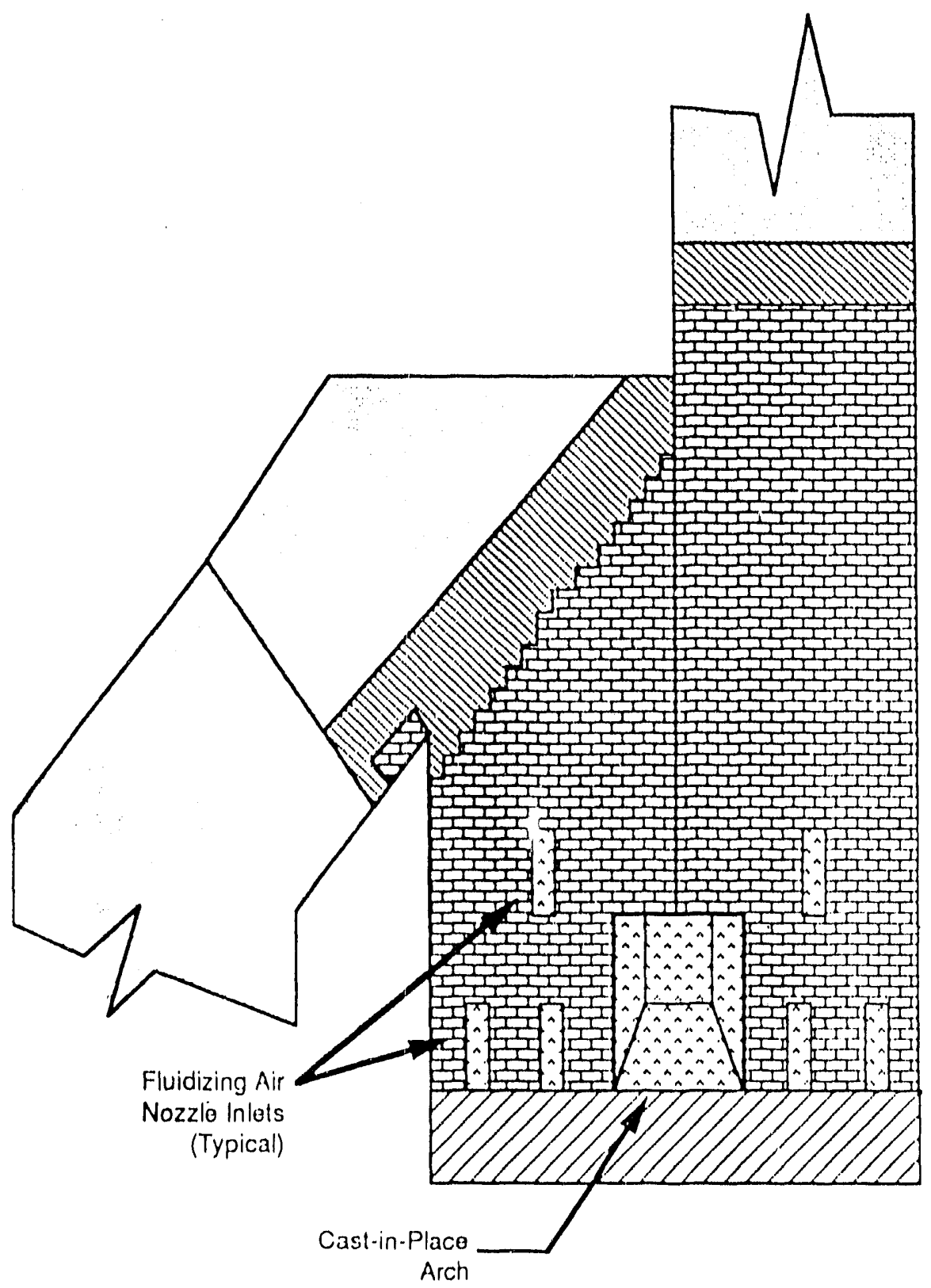

$\square$ Original Retractory

Now Refractory

New Firebrick

A. New Cast-in-Place

FIGURE 7 -- LOOP SEAL REFRACTORY REPAIR 
These repairs will be monitored periodically to determine if these changes improved performance.

\section{Miscellaneous}

Refractory and firebrick performance in the bottom ash coolers has not been a problem. Refractory in the windbox is normally designed for insulating purposes; however, with the occurrence of any backsifting of bottom ash or dust carryover from regenerative air preheaters it may be prudent to install a thin layer of abrasion resistant refractory over the insulating refractory. 


\section{2 .9 CENTRAL SOYA}

Central Soya operates a $88 \mathrm{kpph}$ Pyropower CFB in Chattanooga, Tennessee. The unit began operation in December of 1985 and has run approximately 708 of the time. Steam conditions for the unit are $190 \mathrm{psi}$ and $384 \mathrm{~F}$, produced from burning a medium sulfur $(<28)$ coal.

\section{Combustor}

The waterwall combustor, measuring approximately 9 feet square, has the lower seven feet protected with a gunited plibrico refractory on the studded walls. The refractory in this area has experienced some cracking and spalling, but has not required any major repairs. Tips of the studs are showing in several areas on the walls. The top one foot of this refractory has been redone.

\section{Cyclone}

Major repairs were required in the cyclone and downcomer in April of 1987. The original refractory (Plibrico) consisted of 8-inches of insulating refractory covered with 4 -inches of abrasion resistant refractory. Repairs were made using Combustion Engineering (now Premier) Blue Ram H.S. and Hot Top Moldit. Y-anchors are studded directly to the cyclone metal shell on approximately a one-foot $x$ one-foot pitch. The cyclone and downcomer required a second major repair during the summer of 1989 . The insulating refractory is being replaced with A. P. Green Kast-Set 2700 F castable, with A.P. Green LoAbrade being used in tue downcomer. The cyclone barrel is being redone with brick using a high alumina T-36 cement. In the boiler outlet/cyclone inlet section, Harbison-Walker Coral Plastic is being used. This material is a 858 alumina phosphate bonded, heat setting plastic refractory. Sumit City Boiler Service made these repairs. They recommended against using stainless steel needles in this application, citing a tendency for the needles to settle out at the lower portion of pours. Needles can burnout up to 2 to 4 -inches into the refractory which can leave the refractory weakened.

Operating problems have been primarily pluggage of the ash cooler due to spalled pieces of refractory. The largest pieces of refractory found have been six to eight inches in diameter. The ash cooler was initially lined with a cast refractory, but spalling problems resulted in this material being removed and the cooler lined with brick. Bricks are also used in the loop seal return line to the combustor. 


\section{2 .10 B. F. GOODRICH}

The B. F. Goodrich plant located in Henry, Illinois has a Pyropower CFB that began operation in October of 1985 . The unit produces $125 \mathrm{kpph}$ of steam at $500 \mathrm{psi}$ and $470 \mathrm{~F}$. To date, the unit has operated for approximately 25,000 hours.

A general comment on the B. F. Goodrich plant is that refractories have not been a problem. All the refractory was installed in the field and was gunned on except from the cyclone outlet to the combustor which was poured. Harbison-Walker refractories were installed by V. J. Mattson Company.

\section{Combustor}

The combustor, which is approximately 11-foot square, is constructed of waterwalls with approximately the lower eight feet of elevation protected with a nominal 3-1/2-inches of Hargun ER abrasion resistant refractory. The unit is equipped with five gas lances that are used during loss of coal or for load cycling. Some spalling has been experienced around these ports due to expansion problems. Bed material got behind the refractory in one instance and caused a waterwall tube leak. This leak in turn soaked the refractory in the windbox causing it to have to be replaced. The unit was down for a summer inspection this year and minor patch work was being done around the gas lance ports. Castolast ' $G$ ' with $3 \%$ by weight of stainless steel needles was used to make these repairs. The floor of the combustor has six inches of Light Weight Cast 22 .

The poured refractory (cyclone outlet to combustor) has seen some cracking and wear. This was noticed after the first year of operation, but has stabilized since then with no repairs required. The two coolers are lined with 5-inches of Harcast ES which have not required any repairs. The cyclone, downcomer, and loop seal are lined with 12 inches of Harvibe Light Weight Gun Mix 22 and Hargun ER. No major repairs have been required in these areas.

The unit is cooled down by cutting the fans off and opening the access doors and allowing natural draft to cool the unit (approximately $200 \mathrm{~F} / \mathrm{HR}$ ) . 


\subsubsection{CALIFORNIA PORTLAND CEMENT}

California P rtland Cement operates a $190 \mathrm{kpph}$ Pyropower CFB, referred to as "Calmat", at colton, California. Steam conditions for the unit are 650 psi and $825 \mathrm{~F}$. The unit cogenerates approximately $25 \mathrm{MWe}$. The unit began operation in April of 1985 and has had a $90 \%$ availability for the last four years. The unit burns a 50/50 $\mathrm{mix}$ of coal and coke and uses ground bottom ash as a supplement to limestone.

\section{Combustor}

The combustor is approximately 60 feet tall and has waterwalls the full length. The lower 9-10 feet of waterwall surface has 3-4 inches of abrasion resistant refractory. The unit still has the original refractory and has seen only minor spalling. Refractory at the combustor exit to the cyclones has experienced significant wear and has been replaced with a more wear resistant material.

\section{Cyclone}

The majority of refractory problems at Calmat have been in the cyclone. The cyclones, as well as other uncooled structures have 5-inches of insulating refractory and 7 inches of hard wear resistant refractory. Severe erosion has occurred in the roof and sidewall of the cyclone barrel section. The original gunned material spalled off in some areas near the inlet due to poor installation. Expansion joints produced uneven surfaces which aggravated the erosion potential.

Each year, this section of the cyclones is patched with a ramable plastic which sets at $900 \mathrm{~F}$. The rammable plastic has been used with and without the addition of stainless steel needles with no significant difference in performance noted. Pieces of refractories, which spalled after repairs were made, have caused plingged cyclones.

The cone section of the cyclones has experienced spalling and cracking which is believed to be primarily due to not enough expansion allowance. Minor repairs have been made but they are not considered to be a long term solution. Current plans are to replace this material in the cone section with brick in the spring of 1990. 


\section{Downcomers/Loop Seals}

Excessive erosion is the primary refractory problem in the loop seal (roof) and loop seal return. The loop seal return has been replaced with high grade refractory brick which are performing acceptably.

\section{Miscellaneous}

Only minor repairs have been required to the original cast refractory used in the bottom ash cooler. 


\section{2 .12 GENERAL MOTORS-ARGONAUT}

The General Motors-Argonaut plant in Pontiac, Michigan has a $300 \mathrm{kpph}$ Pyropower CFB which cogenerates $(27 \mathrm{MW}$ and $150 \mathrm{kpph})$. Steam conditions are 1460 psi and $955 \mathrm{~F}$. The unit came on line in January of 1987 and has operated the last twelve months with a $98 \%$ availability.

Refractories have not been a major problem. The lower combustor refractory has seen some considerable wear in the dense bed. Wear is to the point where hangers can be seen. Areas of refractory have been patched and cut out and replaced. The cyclones were gunited and are experiencing some cracking, but haven't seen any spalling. The loop seals where they feed back into the boiler have been replaced with insulating and abrasion resistant bricks. 


\section{2 .13 IOWA STATE UNIVERSITY}

Iowa State University has two $170 \mathrm{kpph}$ Pyropower $\mathrm{CFB}^{\prime} \mathrm{s}$ at the Ames, Iowa campus. One unit began operation on coal in september of 1988 and the second unit in December of 1988. Steam conditions at buth units are 410 psi and 750 F. High sulfur bituminous coal is burned in both units. Harbison-Walker refractories were applied to the combustors, cyclones, and loop seals over a period of six weeks.

The lower 12-15 feet of combustor waterwalls are covered with 8 inches of insulating and 2-inches of abrasion resistant (with stainless steel needles) gunned refractory. This section has seen normal cracking in all areas due to thermal expansion. No appreciable erosion or spalling has nccurred. The refractory was cured over a period of three days with temperature hold points of 500,1000 , and $1500 \mathrm{~F}$. A 1 -ft $\times 1$-ft section of wall refractory at the ash cooler inlet did try to pop out. This failure appeared to be due to a poor initial bond and is the only repair made.

The cyclones also have 8 inches of insulating and 2 inches of abrasion resistant refractory lining. Cast sections in the loop seals experienced localized erosion due to direct impingement of limestone in this area. Cast material was replaced in the target area (24-inch $x 30$-inch long section) with brick in January 1.989.

Pyropower conducted a quality control program on the refractory installation with Iowa State personnel monitoring. Core samples were taken from various locations and examined for strength. Loop seal samples failed strength tests twice before finally passing. 


\section{2 .14 PYROPOWER UNIT}

One plant was willing to share refractory experience, but preferred not to be identified by name. This facility has a Pyropower CFB which operates at average steam capacity and high pressure and temperature firing coal.

\section{Combustor}

The lower combustor was initially equipped with a dual layer of Kaolite $1600 / 2300$ refractory installed by Turnaround Maintenance. Because of design changes, the velocity in the lower combustor was increased by adding additional refractory thickness. This modification was made without changing the original anchors and resulted in delamination between the layers. Early in 1989 all the combustor refractory was replaced with Norton Refractory LC904, a gunned silicon carbide material. Exception to this was the use of Harbison-Walker Ruby Chrome rammable plastic which was used around tube bends and combustor penetrations. Approximately 708 of the lower combustor is coated with the gunned refractory and $30 \%$ with the plastic refractory. Studs, $1-1 / 2$ inches long, are used to anchor the refractory to the walls. Examination of this refractory was conducted in May and looked good.

\section{Cyclone}

The cyclones were lined with Kaolite 1600 and 2300 which were gunned on in the field. Erosion of this material in the target zone of the cyclone barrel resulted in local overheating of the cyclone shell. Thermax ES was cast in the cyclone target zone and a diametrically opposite area of the cyclone barrel where erosion was pronounced during an early 1989 outage. This material, installed by J. T. Thorpe, suffered rapid erosion. It is believed that these materials were applied too wet. Later in 1989, this material was torn out and replaced with North American Refractories Alchrome 85P, an 858 alumina plus chrome phosphate bonded plastic refractory. This material is held in place by firebrick anchors.

\section{Loop Seals}

The loop seals were gunned and cast with the same original materials (Kaolite 1600 and 2300) identified above. This area has not seen any significant erosion but has seen some heavy cracking and jacking of the refractory. It appears the useful life of these materials has a maximum service life of approximately three years. Current plans are to replace these materials with a high alumina Andalusite brick. 


\section{2 .15 GILBERTON}

The Gilberton Power Company plant in West Mahoney, Pennsylvania has two Pyropower $\mathrm{CFB}^{\prime} \mathrm{s}$ that produce $355 \mathrm{kpph}$ of steam each. The plant burns processed anthracite culm in the combustors and produces steam at 1500 psi and $955 \mathrm{~F}$. The units began full operation in september of 1988 and have run approximately 80 of the time since.

The combustors have not been a problem but the cyclones have experienced major refractory problems. The cyclones have twelve inches of refractory consisting of six inches of an insulating layer and six inches of abrasion resistant gunited refractory (Thermal Ceramics 122). Repairs have been made with Combustion Engineering (now Premier) Blue Ram plastic refractory. Problems have been encountered with spalling and anchor failures both most likely due to lack of proper expansion. Anchors consist of nuts welded to V-type anchors. The anchor failures are also felt to be due in part to selection of the wrong material (304 stainless steel). Erosion was experienced in the target zone of the cyclone barrels. In June of 1989, the roof refractory buckled and collapsed causing a forced outage. The roof and cone section of the cyclones had the abrasion resistant refractory replaced with a gunned Thermal Ceramics 128. The barrel section of the cyclones had the abrasion resistant refractory replaced with a high alumina Andalusite firebrick from the National Refractories Company. Only minor repairs have been needed in the loop seals. There is some speculation that the high alkaline content of the fuel may have led to a corrosive attack of the refractory. 


\section{2 .16 UNIVERSITY OF MISSOURI}

The University of Missouri operates a $200 \mathrm{kpph}$ Riley Stoker Multisolids CFB unit at the Columbia, Missouri campus. Steam conditions of the plant are 950 psi and $850 \mathrm{~F}$. Startup of the unit began in February of 1988 . The unit has been operated at nominally 508 load with a 458 average availability. A. P. Green was the refractory supplier and installer.

\section{Combustor}

The lower half of the combustor consists of a rectangular cross section steel shell that is lined with a dual layer of refractory. Next to the shell is a 11-inch layer of VSL-35 which is a gunned insulating material which has a maximum service temperature of $2000 \mathrm{~F}$ and is resistant to thermal shock. Over this material is a 6-inch layer of $\mathrm{R} 5011$ abrasion resistant refractory which was poured in place. At the top of the reducing zone, the lower waterwall headers are refractory lined as is the start of the oxidizing zone. Four to five inches of Lo-Abrade, a $50 \%$ alumina abrasion resistant refractory, was gunned in this area. Stainless steel double $Y$-anchors welded to the steel shell hold the refractory in place. Approximately 1-inch of refractory extends beyond the end of the anchors which are installed on approximately a one-foot staggered pitch. Periodic inspection of the refractory in the lower combustor has shown it to develop cracks which with time have opened up to a maximum of 1 inch. These cracks fill with bed material which packs in the gap and causes the cracks to grow with time. No repairs have been needed to date; however, the west wall is showing some signs of bowing away from the shell and will be monitored in future outages.

The upper combustor has 1 inch of refractory on the roof and 2-1/2-inches on the sidewalls near the cyclone inlet. This material is Lo-Abrade which was gunned onto the surfaces to protect them from the dust loading which must make a $90^{\circ}$ turn to enter the cyclones. No wear or spalling has been noted on these surfaces except for localized wear around observation ports. Anchors in these areas are on a tighter spacing ( $\sim 4$ inch square pitch). Cyclone/Downcomer

The unit is equipped with two 10 foot diameter cyclones which are refractory lined with two layers of insulating refractory and a single layer of abrasion resistant material in the cyclone inlet and barrel sections. Starting at the shell the refractory lining consists of 3 inches of Castable Mix 219, 5 inches of VSL-35, and 6 inches of R5008GR. All materials were gunned in the field onto refractory anchors. Some minor spalling has occurred in these areas with larger pieces missing from the cyclone roof around the vortex finder. Minor wear appears to be occurring in the cyclone barrel in the target zone.

The cyclone cone section also has three layers of refractory but, instead of gunned material, are brick. The three layers from the shell toward the hot 
face are 3-1/2-inches of JM SUPEREX 2000 block insulation, 4-1/2-inches of G$201 \mathrm{FB}$ brick, and 6 inches of KX-9 $\mathrm{SBF}$ high fired abrasion resistant brick.

This lining has given excellent service. Below the cone section is an elght foot transition section that delivers the solids to an external heat exchanger. This section is lined with 3 inches of Castable Mix 219, 5 inches of VSL-35, and 6 inches of Lo-Abrade which were all cast. These materials have given good service as well. The cyclone outlet refractory materials are 3 inches of Castable Mix 219, 5 inches of VSL-35, and 6 inches of KS46R from shell to gas outlet. No problems were noted in these cast materials.

\section{External Heat Exchanger}

The solids collected by the two cyclones dump into the end compartments of a refractory lined external heat exchanger (EHE). The solids in these compartments can either be recycled back to the combustor or can flow over dam walls in the EHE to a center compartment which contains in-bed evaporator surface. The EHE behaves as a low velocity bubbling fluidized bed.

The hot compartments are lined with 16 inches of refractory on the walls and roof and are made up of 4 inches of Castable Mix 219, 6 inches of VSL-35, and 6 inches of Lo-Abrade. The floor is lined with approximately 7 inches of VSL35 and 6 inches of Kast-0-Lite 25. The cold and hot compartments are separated by a dam wall. This wall was initially constructed of tongue and groove $\mathrm{KX99BF}$ brick. These bricks came loose and fell into the hot compartments. During the summer of 1989 , these walls were removed and replaced with cast monolithic walls which incorporate expansion joints. These have operated without any problems to date and are only seeing a normal amount of cracking.

The cold EHE compartment, which contains horizontal in-bed evaporator tubing, has 13 inches of refractory on the walls and roof. These linings are made up of seven inches of VSL-35 and six inches of Lo-Abrade. The floor has a three inch layer of Kast-0-Lite 25 on top of approximately five inches of VSL-35.

\section{Return Lines}

The L-valves, hot and cold solids recycle lines and the EHE gas outlet line were cast in the shop and use six to nine inches of refractory. The insulating refractory is Castable Mix 219 and the abrasion resistant refractory is R5011. Localized wear has occurred in these lines and appears to be more a problem with local geometry conditions rather than refractory deficiencies. 


\subsubsection{GENERAL MOTORS - FORT WAYNE}

The General Motors Truck and Bus Group in Fort Wayne, Indiana operate two Riley Stoker Multisolids CF'B's. Each unit produces $150 \mathrm{kpph}$ of steam at 700 psi and $755 \mathrm{~F}$. The units began operation in March of 1987.

These units have been in operation less than 365 days and are still under warranty. Because of this, the owner was reluctant to discuss specifics but did offer a synopsis of the refractory experience.

The units were originally gunited and cast in the field. Problems were experienced with the refractories in the hot and cold recycle lines, lower combustor, all ports, and cyclone inlet. Each of these areas has been repaired two to three times. Their repair criteria has been if the area is less than two square feet it is patched and if larger than two square feet a major rework or replacement is performed. All types of refractories have been used for repairs and replacement, including cast, gunned, and brick. The most successful material seems to be the new plastic refractories.

The main mode of failure is believed to be erosion, as all problem areas have high velocities and high particle loadings. The refractory has been subjected to a lot of cyclic operation due to boiler operation but no thermal shock. expansion failures have been seen.

The rapid loss of refractory is at such a high rate as to make operation and maintenance unacceptable. It is felt that the refractory being used is a misapplication, i.e. it can not handle the high particulate loadings. The General Motors staff recommended that refractory $R \& D$ be performed before $C{ }^{\prime} B^{\prime} s$ can be declared practical for commercial application. 


\section{2 .18 UNIVERSITY OF IOWA}

The University of Iowa operates a $170 \mathrm{kpph}$ Riley Stoker Multisolids CFB at lowa City, Iowa. Steam conditions are $475 \mathrm{psi}$ and $760 \mathrm{~F}$. Operations began during the fall of 1988. Total operating time to date is approximately one month, burning bituminous coal. Initial noise problems resulted in the city requiring the University to put a silencer in the stack. This modification was completed and the unit came back on line in March 1989.

No refractory problems have occurred to date which is not unexpected considering the short operating time. The combustor and cyclone were gunited and the external heat exchanger (EHE) was cast. The dividing walls between the cold and hot EHE compartments are starting to crack and appear to be the first area where refractory problems will occur. Additional operating time is needed to properly assess the refractory in this unit. 


\section{2 .19 A. E. STALEY}

A. E. Staley operates two Riley Stoker Multisolids CFB's at its plant in Decatur, Illinois. Each unit produces $375 \mathrm{kpph}$ of steam at $1265 \mathrm{psi}$ and 955 F. The first unit baked refractories out in August of 1988 and began operation in January of 1989. The second unit began operation in May of 1989.

\section{Combustor}

The combustors measure approximately 8 feet $x 12$ feet in the reducing zone and approximately 10 feet $x 15$ feet in the oxidizing zone. The lower combustor is not waterwall lined and therefore requires two layers of refractory. Originally the refractory was to consist of 9 inches of insulating and 8 inches of hard face refractory. Design changes dictated reducing the velocity in the lower region of the combustor. To assist in lowering the velocity, the combustor refractory installed was only 9 inches thick, consisting of 5 inches of insulating material and 4 inches of hardface material. A. P. Green refractories were installed by George P. Reint jes Company. Cracks formed in the abrasion resistant refractory and were noted to grow larger during each outage. One wall of the first unit has experienced failure of the fasteners and the wall has separated from the combustor. This resulted in an overheating of the casing.

\section{Cyclone}

rihe cyclone refractory is retained by corrugated brick anchors on 8-10 inch spacing. A. P. Green 85P, an 858 alumina phosphate bonded plastic, was used as the hot face refractory (also used in combustor). The cyclones have not experienced any cracking. The cyclone cones are brick lined and have not been a problem. The external heat exchanger has hrc and cold recycle compartments divided by a baffle wall. This monolithic wall is full of cracks and looks susceptible to spalling. The outer walls appear in good shape but the roof has experienced some cracking with the refractory coming off as a sheet. 


\subsection{SUMMARY/RECOMMENDATTONS}

Refractory systems represent a significant and critical portion of the overall design of a circulating fluidized bed facility. For this reason, the refractory design should be integrated early into the design of the unit and not added as a last step before the unit is commissioned. The customer needs to evaluate proposed refractory designs from a life cycle cost standpoint and not just initial capital outlay. Most refractory suppliers have comparable materials; however, it is the installation of these materials that can make or break the success of their application. It is imperative that the installation procedure be developed properly and that quality control measures be taken to see that these procedures are carefully followed. Local concrete contractors are generally not qualified to install refractory concretes yet they are frequently used to save money. Their installations are generally unsatisfactory.

It is beyord the scope and objective of this task to provide detailed design, material selection, and installation procedure recommendations. This section attempts to describe some of the lessons learned, both good and bad. CFB technology has advanced at a rapid pace during the last five years. Conventional boilers required the use of little refructory and therefore, the boiler vendor and refractory supplier/installex have had to develop CFB refractory knowledge together. Much of the work which has been done is a spin off from the $p^{\prime}$ rerochemical industry.

The summary/recommendations below are a result of this refractory survey which includes discussions with boiler vendors, refractory suppliers, owner/operators of CFB units, and literature reviews. Cost of materials and installation have not specifically been incorporated into any of these comments. Costs are volatile, with one boiler vendor stating the price of refractories has increased by a factor of three to four during the last four years. The customer has to weigh these costs, as well as scheduli impacts, into his final selection. The customer should consult the boiler vendor and refractory supplier and installer for specific recommendations. 


\subsection{MATERIAL SELECTION}

\section{1 .1 INSULATING}

Insulating refractories, in general, have not been a problem in CFB's. Operating temperature in $\mathrm{CFB}^{\prime} \mathrm{s}$ is nominally $1600 \mathrm{~F}$. The temperature at the interface of the insulating refractory with the abrasion resistant refractory is even lower. However, with clinkering, temperature excursions (due to startups, shutdowns, process upsets, etc.), and potential for loss of hard face material, a margin of safety should be included. A minimum of a $2000 \mathrm{~F}$ material should be selected. Gunning, casting, and bricks have all been used successfully. With the lower combustor operating in a reducing environment, it would be prudent to select a low iron content material.

\section{1 .2 ABRASION RESISTANT}

In the lower combustor where dual layexs of refractory are required, high alumina castables ej.ther gunned or vibration cast appear to be successfully used. This materia?, used with stainless steel fibers and moisture release fibers, should provide long term operation without major problems. Low iron content is recomnended due to local reducing conditions. Iron oxide can react with carbon monoxide and deposit carbon which can result in refractory cracking. Units which have waterwalls in the lower combustor require only a single layer of refractory. Silicon carbide either gunned or tile products have proven successful in this application. Gunned silicon carbide is also recommended for the combustor outlet and roof sections where refractory is required.

The cyclones have proven to be the most challtnging component for developing a successful refractory design. It was the consensus opinion that gunned materials sre not available today that can stand up to this harsh environment. Even though there are exceptions to this finding, most of the boiler vendors are designing all future units with brick. Hard fired high alumina brick or high alumina vibration cast materials should give good service. Phosphate bonded alumina plastic refractories have been used successfully in the target zone and roof areas of cyclones.

Similar to cyclones, many of the bniler vendors are replacing existing loop seal refractories and designing new loop seals with brick or a combination of brick and cast refractory. The major problem in the loop seal appears to be associated

with thermal expansion problems. The materials suggested for cyclones should be suitable for loop seals also. Fused silica, which is 100 \& amorphous, has extremely low thermal expansion properties which give it excellent thermal shock resistance. This material would be suitable for loop seals. The maxim:m temperatures should be mintained below $2000 \mathrm{~F}$ to prevent 
devitrification. The dip leg/downcomer line to the loop seal can be vibration cast.

\subsection{INSTALLATION METHODS}

\section{2 .1 GUNNING}

Most of the refractory in CFB's has been applied with this technique. It allows more material to be put in place in the least amount of time. However, this installation method is dependent on the skill of the gunner/nozzleman who can make or break the success of the application. Dry refractory material is blown onto the surfaces to be lined using compressed air with water typically added at the nozzle. An improved gunning technique mixes a portion (up to hali) of the water with the dry materials ahead of time with the remaining water mixed at the nozzle. Benefits of this technique are increased density, decreased rebound, and decreased dusting. Rebound is the refractory material that doesn't stick to the surface but bounces off as waste. This material is predominantly the larger coarse fraction of particles and should not be reused. Proper pre-mixing of water should allow a ball of the refractory mixture to be formed which can be easily crumbled with finger pressure. Rebound should be able to be controlled to no more than 10-158 which helps hold cost down.

The proper method of applying the gunned material is to start at the base and corners and work your way up. This allows the rebound material to fall clear of the uncoated surfaces. Once started, installation should not be stopped even for a ten minute break. It is recommended that the nozzle be perpendicular to the wall, about four feet away. Small areas should be gunned in horizontal ovals tc prevent the material from drying out which can result in laminations. The finished product should not be troweled or floated smooth. This works the fine material to the surface and closes up pores that are needed for proper dryout. Also, materials should be applied at 60-80 F and should not be allowed to freeze before the curing cycle is completed.

Gunning is recommended for installing the insulating refractory layer in CFB's, but is not the preferred installation method for the abrasion resistant refractory, except for maybe the lower combustor. Gunned materials have not, in general, performed acceptably in the cyclones and loop seals. Because gunning is fast and cost effective this would be one area where development work could help hold down the capital cost of $\mathrm{CFB}^{\prime} s$. Gunned plastics offer some room for optimism. 


\section{2 .2 CASTING}

Refractories can also be installed by casting, which involves pouring the material into a form. This technique is quick and easy to use and requires less skill than gunning. This method requires mixing the material at the site with water. The water used should have a purity suitable for drinking, and the water, mix, and structure to be lined should be at a temperature of 65-90 F. Refractory should never be installed at temperatures below $65 \mathrm{~F}$. Use of more than the recommended amount of water can result in weakened refractory. The refractory and water should be mixed mechanically for two to five minutes at the most. The proper consistency of the mixed product can be evaluated using the "ball. in hand" test. A ball of the mixed product is formed and tossed 6-12 inches into the air and caught. The material should conform to the shape of the hand when caught and should not flow between the fingers (too much water) or crumble (to little water).

Vibration casting of materials uses only about one half the amount of water used for conventional casting. Vibration casting increases the density and strength of the final product and reduces its porosity. A paddle type mixer is recommended for mixing vibration cast materials to assure that the reduced amount of water is properly mixed with the solids. Longer mixing times (approximately 4 minutes) are also recommended. The refractory mix should be put in place within 30 minutes which is typically the amount of material that should be prepared in each batch. High purity materials should be put in place within 15 minutes.

The forms or molds should not absorb water from the casting during the cure cycle or else a reduced strength prcduct will result. Pre-wetting or moisture proofing of the forms should be done as necessary to prevent this from happening. After casting, the surface should be covered (plastic) to prevent water loss during the curing cycle and the material should be maintained at the 65-90 F temperature for at least 24 hours. The forms can be removed after about eight hours. After curing, the manufacturer's dryout schedule should be followed. Typically, about 1 hour of hold time is needed for each inch of lining thickness. Free water will be driven off at approximately $212 \mathrm{~F}$ and hydration water will come off between 400-1600 F. Vibration casting can be performed by vibrating the form externally or with a surface vibrator. Immersion vibration is not recommended. Too much vibration will cause the aggregate to separate out of the mixture. The effect of vibration casting of a second layer of refractory on top of an installed layer should be considered.

\section{2 .3 RAMMING}

Ramming is another method of installing refractories in CFB's, particularly plastic refractories. These materials are essentially pre-fired refractories that are prepared in a stiff plastic condition by the refractory supplier and 
delivered to the site with no further preparation or mixing required. These materials are rammed into place with hand held pneumatic hammers or mallets. The plastics are provided in the high density abrasion resistant form and can be either air or heat setting types. The main precaution in ramming plastics is to not put too much material down at one time. The material must be knitted together. The use of a notched hammer is recommended to perform this knitting to prevent laminations. The high success of rammed plastics is due to the improved material properties and the ease of installation with no mixing required.

\subsection{ANCHORING}

Proper anchoring is critical to successful refractory linings. For circulating fluidized beds, "V" or "Y" anchors are used almost exclusively, except for some use of ceramic anchors. Metal anchors should be made of 309 or 310 S.S, which are good to $1600-1800$ F. Ceramic corrugated brick are good for higher temperatures. Hex mesh and road mesh screen type are not recommended as they are prone to failing in sheets. Metal anchor length should nominally be 60 to 808 of the refractory thickness. Ceramic anchors are placed full depth, flush with the outer surface. Anchors should be coated with paint, grease, wax, asphalt tape, or plastic which melt on heat up to allow room for the anchors and refractory to expand without cracking the refractory. Spacing of the anchors is dependent on the refractory thickness and orientation of the surface. Anchors are typically placed on one foot centers, except roofs which are spaced about 9 inches apart. Crowley, in reference 5, gives an analytical method to estimate anchor spacing. More anchors are needed near edges, ports, and other areas that are subjected to vibration or mechanical movement. V-and-Y-anchors should have the legs staggered 90 degrees from each other. Anchors should be properly attached to the shell. This attachment can be checked in the field by rapping the anchors with a hammer or by using a pipe to bend the legs of the anchor. The hammer rap should give a sharp ringing sound and the pipe test should allow the anchor to be bent flat without failing the attachment. If failures are found, all anchors should be tested. Sandblasting of the shell will improve the refractory adherence by creating a textured and clean surface.

Significant cost reductions could be made if uncooled shell temperatures could be increased to $650-700 \mathrm{~F}$. These temperatures are well below the oxidation temperature limit of the materials involved but refractory suppliers and installers feel anchor designs do not exist that can function at these temperatures today. Development work in this area could result in lower capital costs for $\mathrm{CFB}^{\prime} \mathrm{s}$. 


\subsection{STAINLESS STEEL FIBERS}

Stainless steel fibers are added to castable and plastic refractories to improve refractory strength, spalling resistance, abrasion resistance, thermal shock resistanca, and crack resistance. Most of the CFB units use approximately $3-4 \%$ by weight of stainless steel fiber reinforcement. The fibers can be added to cast, rammed, or gunned products. Most sites indicate better performance with stainless steel fiber addition; however, at least one site saw no appreciable difference in performance with the addition of stainless fibers, and one installer indicated that stainless fibers could cause problems, such as settling out and burning out. These problems are believed to be the result of use of the wrong material and/or improper mixing of the fibers in the refractory. The use of $310 \mathrm{ss}$ fibers should be suitable for $\mathrm{CFB}$ operating refractory temperatures. Stainless steel fibers can be provided mixed with the refractory from the suppliers or can be mixed at the site.

Fibers are typically $1-1-3 / 8$ inches long $x$ about $1 / 64$ inch diameter. The metallic fibers expand more than the refractory material and cause a network of "mini-cracks" which improves thermal shock performance, as opposed to a few large cracks forming which can result. in pinch spalling in CFB's. The fibers have little influence in the overall thermal conductivity of the refractory.

\subsection{MOISTURE VENTING FIBER}

The hydration of calcium aluminate cements is critically tied to the curing temperature. If too low a temperature is used, appreciably more moisture will be released during the drying cycle. With the use of low permeability refractories, rapid release of large amounts of moisture can build up pressure and cause explosive spalling. To minimize this problem, refractories can be purchased which contain fibers that provide paths for the steam to be vented. Some fibers actually shrink and burn out as the refractory temperature is raised close to $200 \mathrm{~F}$. Other fibers are tubular in design and provide a natural path for the moisture to escape. The addition of these fibers is particularly recommended for cold weather installations. The resulting refractory installation with the addition of these fibers has better strength properties with less cracking. A typical example of this product is given in Appendix A.

\subsection{CORROSION}

Refractory materials are typically selected based on their insulating and 
abrasion resistance. Corrosion is usually a secondary factor. The circulating fluidized bed application should be less of a concern than other applications because of the low (approximately $1600 \mathrm{~F}$ ) operating temperatures of $\mathrm{CFB}^{\prime} \mathrm{s}$. However, a few of the CFB units reported that it appeared corrosion played a part in the poor performance of their refractories.

Chemical reactions can contribute to the destruction of refractory linings. In $\mathrm{CFB}^{\prime} \mathrm{s}$, this may be somewhat masked by the removal of the corrosion products by the abrasive nature of the circulating particulate. Refractories can react with the fuel ash, sorbent, and flue gas. These reactions can result in changes in the refractory crystal structure and even produce liquids. Phase diagrams can be used to determine what reactions are possible and can estimate at what temperatures they will occur. Sodium and potassium, for instance, can react with silica at temperatures below $1500 \mathrm{~F}$. Fireclay refractories can react with limestone but require a higher temperature (approximately 2500 F) than normal CFB operation. Generally, acid refractories should be used where acid fluxes exist and vice versa. Silicon nitride bonded silicon carbide has better alkali resistance. Steam environments, as in water sprayed bottom ash coolers, accelerate the transformation of silicon carbide to silica which can result in spalling.

The reducing condition in the lower portion of the combustor is an area where corrosion may be a factor. High carbon monoxide levels can react with iron oxide in the refractory. Hydrogen can attack silica bearing refractory at temperatures above $2200 \mathrm{~F}$. Reducing conditions also produce lower melting temperature slags. Proper selection of metal materials for anchors and strengthening fibers need to made based on the environment and temperatures expected.

In a related subject, the use of chrome bearing refractories should be carefully considered. Chromic oxide in used refractories presents a problem for removal and disposal because of its toxicity. This material is classified as a hazardous waste.

\subsection{QUALITY CONTROL}

It is recommended that a third party refractory inspector be employed to oversee the installation of the refractory lining for $\mathrm{CFB}^{\prime} \mathrm{s}$. Refractory supplier and installer should be required to develop an installation procedure which should be reviewed and adhered to. The inspector should be responsible for testing both the raw materials and the installed materials for conformance to specifications. Since refractory installers are not required to have any type of certification, it would be prudent to have them qualify by successfully preparing test samples prior to actually beginning work on the unit. Samples should also be taken during insiallation to verify the asinstalled quality. 


\subsection{REFERENCES}

1. Walker, D.J., "Babcock-Ultrapower Wood Burning Power Plants Materials Considerations," EPRI Workshop on Materials Issues in Circulating Fluidized Bed Boilers, Argonne, IL, June 19-23, 1989.

2. Zychal, R.J., and Darling, S.L., "A Sumnary of Combustion Engineering's Erosion/Wastage Experience in CFB Boilers," EPRI Workshop on Materials Issues in Circulating Fluidized Bed Boilers, Argonne, IL, June 19-23, 1989.

3. Colorado-Ute Nucla Station CFB Demonstration, Sixth Quarterly Technical Progress Report, EPRI Research Project RP2683-7, edited and published by Bechtel National, Inc.

4. Elsner, R.W., and Friedman, M.A., "CFB Materials Related Issues at CUEA Nucla Station," EPRI Workshop on Materials Issues in Circulating Fluidized Bed Boilers, Argonne, IL, June 19-23, 1989.

5. Crowley, M.S., and Fisher, R.E., "Petroleum and Petrochemical Applications for Refractories," Handbook of Science and Technology on Alumina Chemicals, American Ceramics Society, 1987. 
APPENDIX A

INFORMATION

FROM

REFRACTORY

SUPPLIERS 


\section{REFRACTORY SUPPLIERS}

1. A. P. Green

2. Combustion Engineering (now Premier)

3. Harbison - Walker

4. North American Refractories

5. Norton

6. Plibrico 
A. P. GREEN 


\section{INSULATING BRICK}

Only A. P. Green manufactures insulating brick by the revolutionary GREENLITE process ... giving properties superior or equal to any other insulator on the market. Produced from uniform sized, multicellular lightweight aggregate having a strong, ribbed internal structure - resulting in extra high strength and low density.

GREENLITE are available in three distinct classes for use at higher temperatures ... plus GREENLITE-KL, an insulating rotary kiln liner for use in cooler portions of the kiln.

Regular lower temperature insulating brick are also available. These possess the three most desirable properties of insulating firebrick; high insulating value, structural strength, and the ability to withstand temperatures without shrinkage.

\begin{tabular}{|c|c|c|}
\hline BRAND & $\begin{array}{l}\text { TEMPERATURE } \\
\text { RANGE }\end{array}$ & REMARKS \\
\hline $\begin{array}{l}\text { G-20 } \\
\text { G-23 } \\
\text { G-26 } \\
\text { GREENLITE-28 } \\
\text { GREENLITE-30 } \\
\text { GREENLITE-33 } \\
\text { GREENLITE-KL }\end{array}$ & $\begin{array}{l}2000^{\circ} \mathrm{F} . \\
2300^{\circ} \mathrm{F} . \\
2600^{\circ} \mathrm{F} . \\
2800^{\circ} \mathrm{F} . \\
3000^{\circ} \mathrm{F} . \\
3300^{\circ} \mathrm{F} \text {. }\end{array}$ & $\begin{array}{l}\text { Regular insulator } \\
\text { Regular insulator } \\
\text { Regular insulator } \\
\text { Greenlite process } \\
\text { Greenlite process } \\
\text { Greenlite process } \\
\text { Greenlite process } \\
\text { kiln liner }\end{array}$ \\
\hline
\end{tabular}
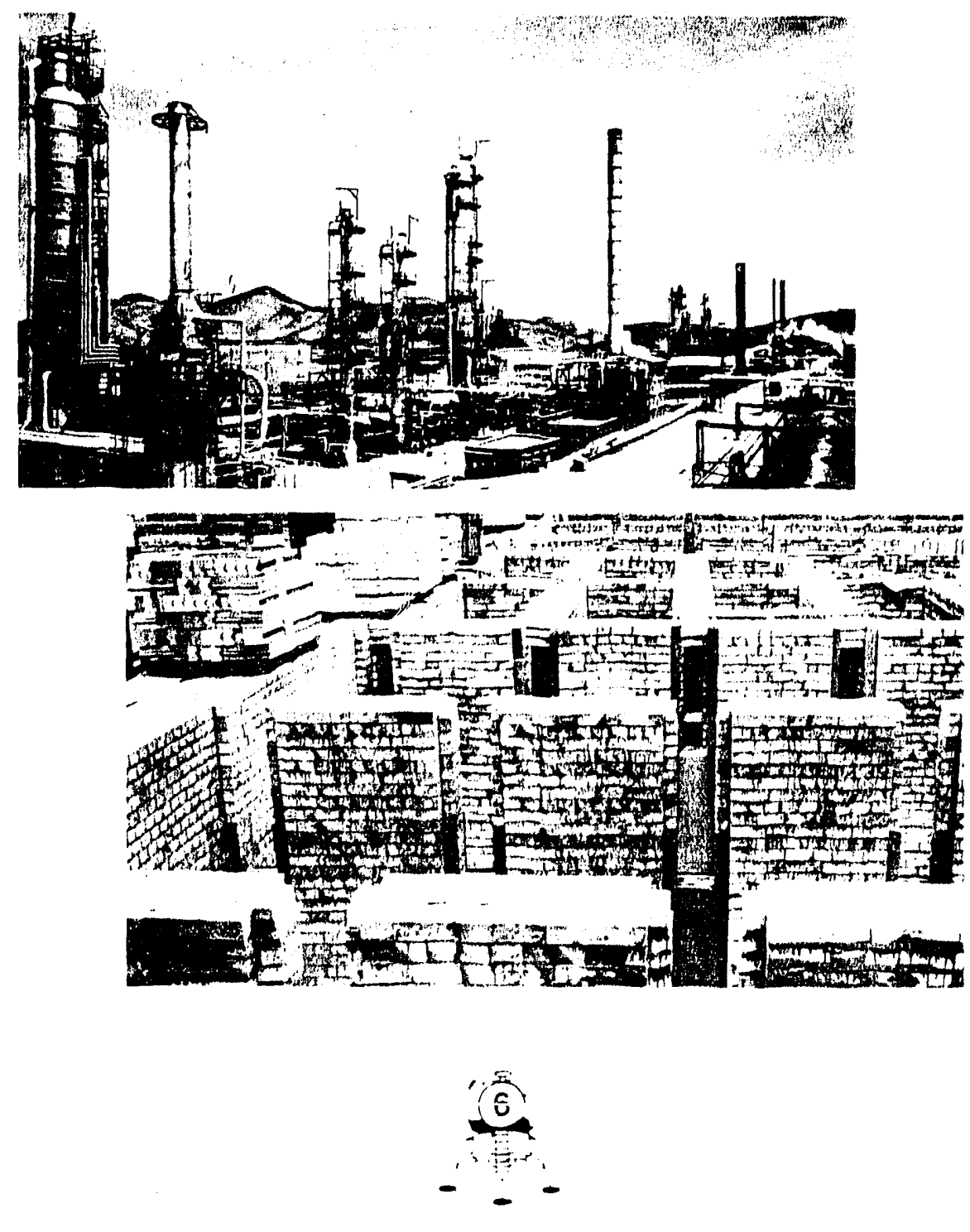


\section{HIGH DUTY}

A. P. Green high duty fireclay brick have properties that assure reliable service in all applications where tempertures or chemical attack is not beyond their recommended ranges. A. P. Green high duty fireclay brick have those features which provide longer, more trouble-free service: resistance to vitrification and spalling, good load bearing ability, slag resistance, and outstanding physical and chemical uniformity.

\begin{tabular}{lll} 
BRAND & PROCESS & QUALITY \\
\hline EMPIRE & DP,SM & High Duty \\
EMPIRE S & DP & High Duty \\
IDAHO & DP & High Duty
\end{tabular}
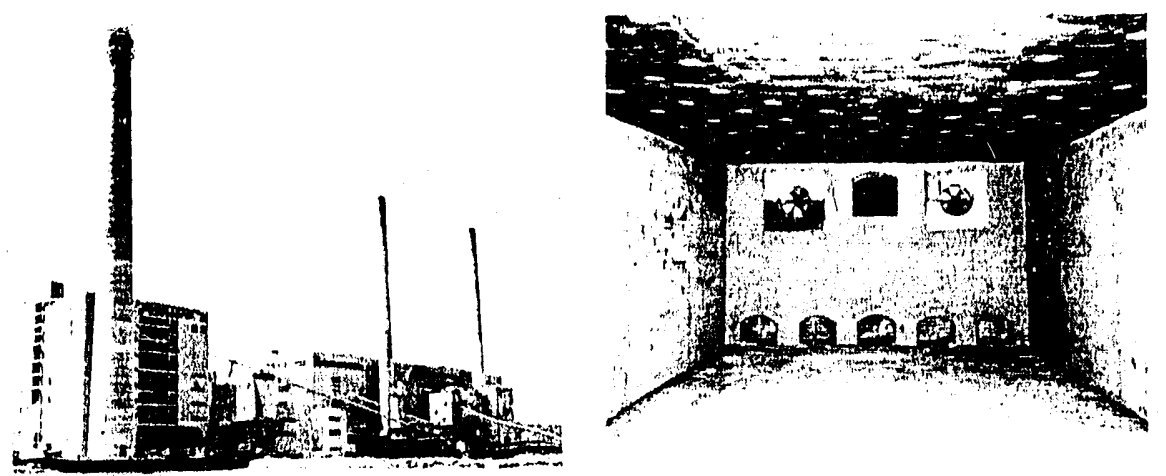

\section{SUPER DUTY}

A perfect balance of physical and chemical properties, enhanced by strict laboratory control and rigid tests at every stage of manufor.ture, make A. P. Green super duty fireclay brick the outstanding choice for those applications where operating conditions are above normal and maintenance costs are high.

All A. P. Green super duty brick have high refractoriness, permanency of volume, amazing resistance to destructive spalling, great load bearing strength with less deformation under load at high temperatures than high duty brick, and a dense structure which resists corrosive slags, fumes, dust, and penetration of molten metal.

\begin{tabular}{ll} 
BRAND & PROCESS \\
\hline CLIPPER & DP, SM \\
CLIPPER S & DP \\
YUKON & DP
\end{tabular}

\section{HIGH FIRED SUPER DUTY}

These are super duty brick fired to unusually high temperatures forming a stable mineral structure which gives them exceptional strength, low porosity, and greater load bearing strength. They are highly resistant to abrasion - to the washing action or penetration of fluid slags or molten metal.

BRAND

$\mathrm{KX}-99$

KX-99-BF

\section{PROCESS}

DP (also available tempered/impregnated) DP (also available tempered/impregnater')

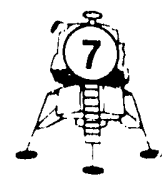




\section{HIGH ALUMINA BRICK}

The Green Company manufactures high alumina brick ranging from $50 \%$ to $80 \%$ alumina content. These brick are service proved to provide outstanding refractory life in a multitude of applications. Their high alumina content provides protection at higher temperatures and each features high resistance to spalling and slag attack, high strength to protect againist load deformation, lack of shrinkage for tighter brick-tobrick joints, and low porosity to guard against metal, gas, and dust penetration.

\begin{tabular}{|c|c|c|c|}
\hline BRAND & $\mathrm{Al}_{2} \mathrm{O}_{3}$ & CONTENT & P.C.E. \\
\hline $\begin{array}{l}\text { MIZZOU } \\
\text { KRUZITE D } \\
\text { KRUZITE R } \\
80 \% \text { ALUMINA }\end{array}$ & $\begin{array}{l}60 \% \\
70 \% \\
70 \% \\
80 \%\end{array}$ & $\begin{array}{l}\text { Also } \\
\text { Available } \\
\text { Tar/Impregnated }\end{array}$ & $\begin{array}{l}\text { Cone } 36-37\left(3279-3300^{\circ} \mathrm{F} .\right) \\
\text { Cone } 37-38\left(3308-3335^{\circ} \mathrm{F} .\right) \\
\text { Cone } 37-38\left(3308-3335^{\circ} \mathrm{F} .\right) \\
\text { Cone } 38-39\left(3335-3389^{\circ} \mathrm{F} .\right)\end{array}$ \\
\hline
\end{tabular}

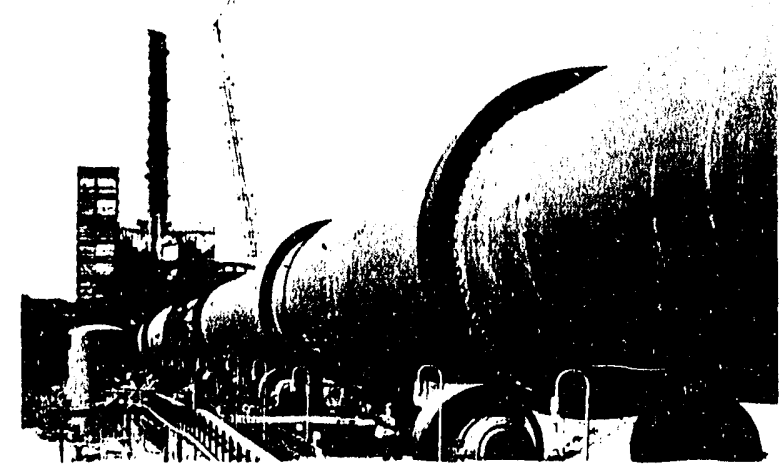

\section{SPECIAL HIGH ALUMINA BRICK - MULLITE BASE}

In addition to the normal types of high alumina brick, the Green Company manufactures a special $60 \%$ alumina, semi-mullite type product branded GREENMUL-60 which has superior stability and lower porosity compared with regular $60 \%$ alumina brick. A low alkali content gives GREENMUL-60 high refractoriness and excellent high hot load strength.

BRAND $\mathrm{Al}_{2} \mathrm{O}_{3}$ CONTENT

P.C.E.

GREENMUL-60 $60 \%$

GREENMUL-60 T.I. 60\%, Tar/Impregnated

Cone 36-37 (3279-3308 F.) Cone $36-37\left(3279-3308^{\circ} \mathrm{F}.\right)$
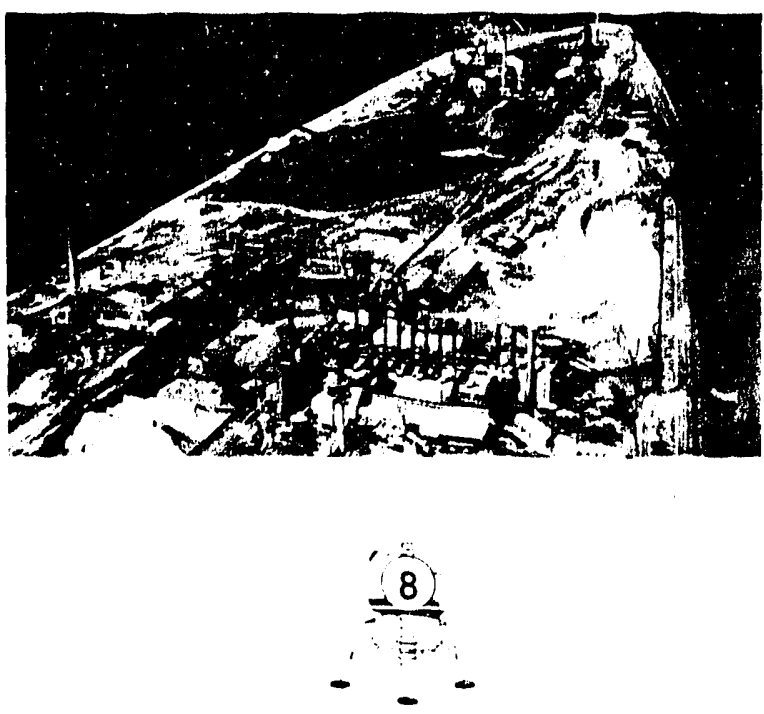


\section{EXTRA HIGH ALUMINA BRICK}

A full line of extra high alumina content brick ranging from Cone 39-40 to Cone 42 is manufactured by A. P. Green. Compared with lower alumina brick, they have a higher modulus of rupture and crushing strength, better load bearing qualities, and are more refractory and more resistant to the fluxing action of various basic oxices. They are exceptionally volume stable and 99-AD can be used at temperatures as high as $3500^{\circ} \mathrm{F}$.

\begin{tabular}{lll} 
BRAND & $\mathrm{Al}_{2} \mathrm{O}_{3}$ CONTENT & P.C.E. \\
\hline DV & $85 \%$ & Cone $39-40\left(3389-3425^{\circ} \mathrm{F}.\right)$ \\
DV-38 & $85 \%$ (ceramic/chemical bond) & Cone $39-40\left(3389-3425^{\circ} \mathrm{F}.\right)$ \\
$90-\mathrm{B}$ & $90 \%$ & Cone $40+\left(3425^{\circ}+\mathrm{F}.\right)$ \\
GREENAL-90 & $90 \%$ & Cone $40\left(3425^{\circ}+\mathrm{F}.\right)$ \\
GREENAL-94 & $94 \%$ & Cone $41-42\left(3578-3659^{\circ} \mathrm{F}.\right)$ \\
$99-A D$ & $99 \%$ & Cone $42\left(3659^{\circ} \mathrm{F}.\right)$
\end{tabular}

\section{MORTARS}

Refractory mortars specifically developed for laying up various types of refractory brick are found in the Green Line of Mortars. In each case the mortar has the chemical composition best suited for the type of brick and service conditions for which it was designed. All A.P. Green mortars possess the fine grain sizing and smooth workablity needed to produce thin brick-to-brick joints ... . a necessity in good brick construction. Mortars are available in both heat and air setting bonds and in wet and dry consistencies.

\begin{tabular}{|c|c|c|c|c|c|c|}
\hline Product & Type & $\begin{array}{l}\text { Setting } \\
\text { Charac- } \\
\text { teristlcs }\end{array}$ & $\begin{array}{l}\text { Shlp- } \\
\text { ping } \\
\text { Condl- } \\
\text { tion }\end{array}$ & $\begin{array}{l}\text { Container } \\
\text { Slze }\end{array}$ & $\begin{array}{l}\text { Lbs Req } \\
\text { Per 1000 } \\
\text { 9"Strta- } \\
\text { Dlpped }\end{array}$ & $\begin{array}{l}\text { Maximum } \\
\text { Rocomd. } \\
\text { Temp. }\end{array}$ \\
\hline MEXI-KOMO & Fireclay & Heat-Set & Dry & $100 \mathrm{lb} .8 \mathrm{gags}$ & $250-300$ & $3000^{\circ} \mathrm{F}$. \\
\hline SATANITE & High Alumina & Heat-Sel & Dry & $100 \mathrm{lb}$. Bags & $250-300$ & $3200^{\circ} \mathrm{F}$ \\
\hline 'SAIRSET & $\begin{array}{l}\text { Super Duty } \\
\text { Fireclay }\end{array}$ & Alr-Set & Wet & $\begin{array}{l}15,50,100 \mathrm{lb} \text {. Pails } \\
200 \mathrm{lb} \text {. Drums }\end{array}$ & $350-400$ & $3000^{\circ} \mathrm{F}$. \\
\hline 'SAIRBOND & $\begin{array}{l}\text { Super Duty } \\
\text { Fireclay }\end{array}$ & Air-Set & Dry & $100 \mathrm{lb}$. Bags & $250-300$ & $3000^{\circ} \mathrm{F}$ \\
\hline 'SAIRMIX-7 & $\begin{array}{l}\text { Super Duty } \\
\text { Fireclay }\end{array}$ & Alr-Set & Wet & $\begin{array}{l}15,50,100 \mathrm{lb} \text {. Pails } \\
200 \mathrm{lb} \text {. Drums } \\
100 \mathrm{lb} \text {. Cartons }\end{array}$ & $350-400$ & $3000^{\circ} \mathrm{F}$ \\
\hline $\begin{array}{l}\text { NO. } 36 \\
\text { REFRACTORY } \\
\text { CEMENT }\end{array}$ & High Alumina & Alr-Set & Wet & $\begin{array}{l}15,50,100 \mathrm{lb} . \text { Pails } \\
200 \mathrm{lb} \text {. Drums }\end{array}$ & $400-450$ & $3200^{\circ} \mathrm{F}$. \\
\hline LOXOL-65 & High Alumina & Alr-Set & Dry & 100 lb. Bags & $350-400$ & $3200^{\circ} \mathrm{F}$. \\
\hline $\begin{array}{l}\text { No. T-36 } \\
\text { REFRACTORY } \\
\text { CEMENT }\end{array}$ & High Alumina & Air-Sel & Wet & $\begin{array}{l}100 \mathrm{lb} \text {. Cartons } \\
15,50,100 \mathrm{lb} \text {. Pails } \\
200 \mathrm{lb} \text {. Drums }\end{array}$ & $400-450$ & $3200^{\circ} \mathrm{F}$. \\
\hline GREENSET-85-P & $85 \%$ Alumina & Alr-Set & Wet & $50,100 \mathrm{lb}$. Pails & $\begin{array}{l}450-500 \\
\text { Troweled }\end{array}$ & $3000^{\circ} \mathrm{F}$. \\
\hline $\begin{array}{l}\text { JADE SET } \\
\text { SUPER }\end{array}$ & $\begin{array}{l}\text { Alumina- } \\
\text { Chromic Oxide } \\
\text { Phos. Bonded }\end{array}$ & Air-Sel & Wel & $100 \mathrm{lb}$. Pails & $600-650$ & $3400^{\circ} \mathrm{F}$. \\
\hline
\end{tabular}
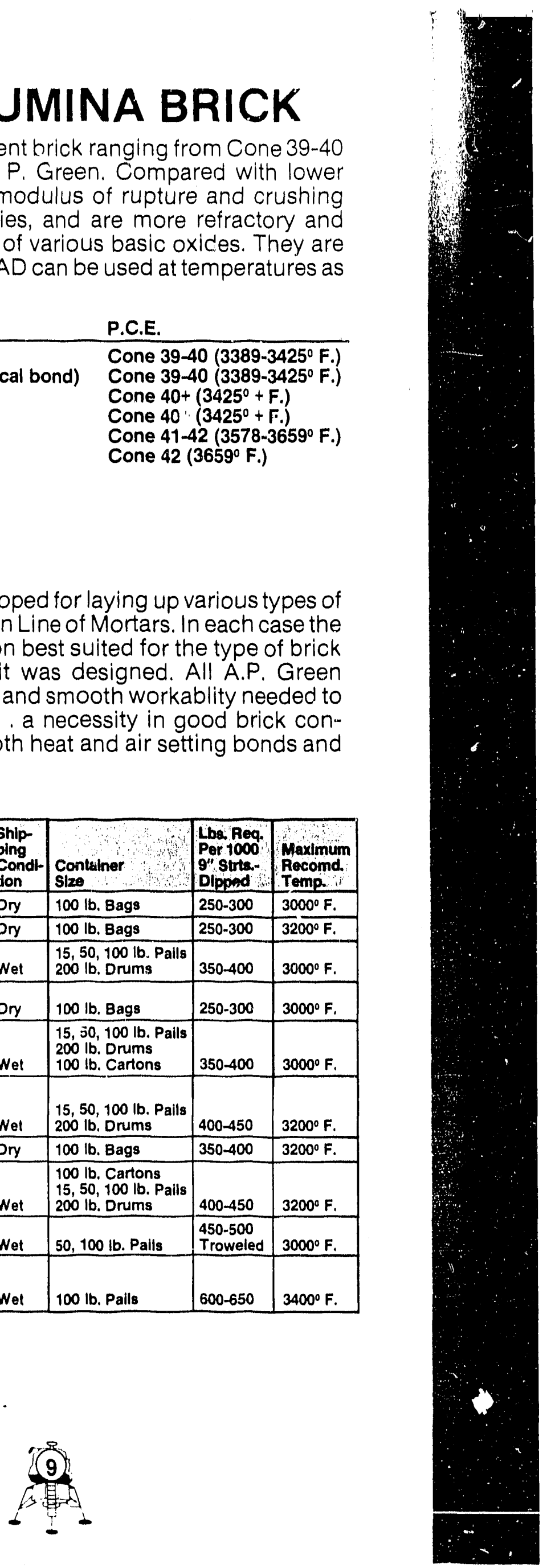


\section{PLASTIC REFRACTORIES}

A. P. Green plastic refiractories are in moldable form, ready to pound into place. They may be installed to form a solid monolithic refractory lining in all types of boilers and industrial furnaces ... plus being used as an effective patching material for quick repairs. Easy to use, plastics save time and labor.

A. P. Green plastics combine high fusion, load bearing strength, spalling resistance, and lack of shrinkage. Separate and distinct brands of plastics assure the perfect plasiic refractory for every industrial use.

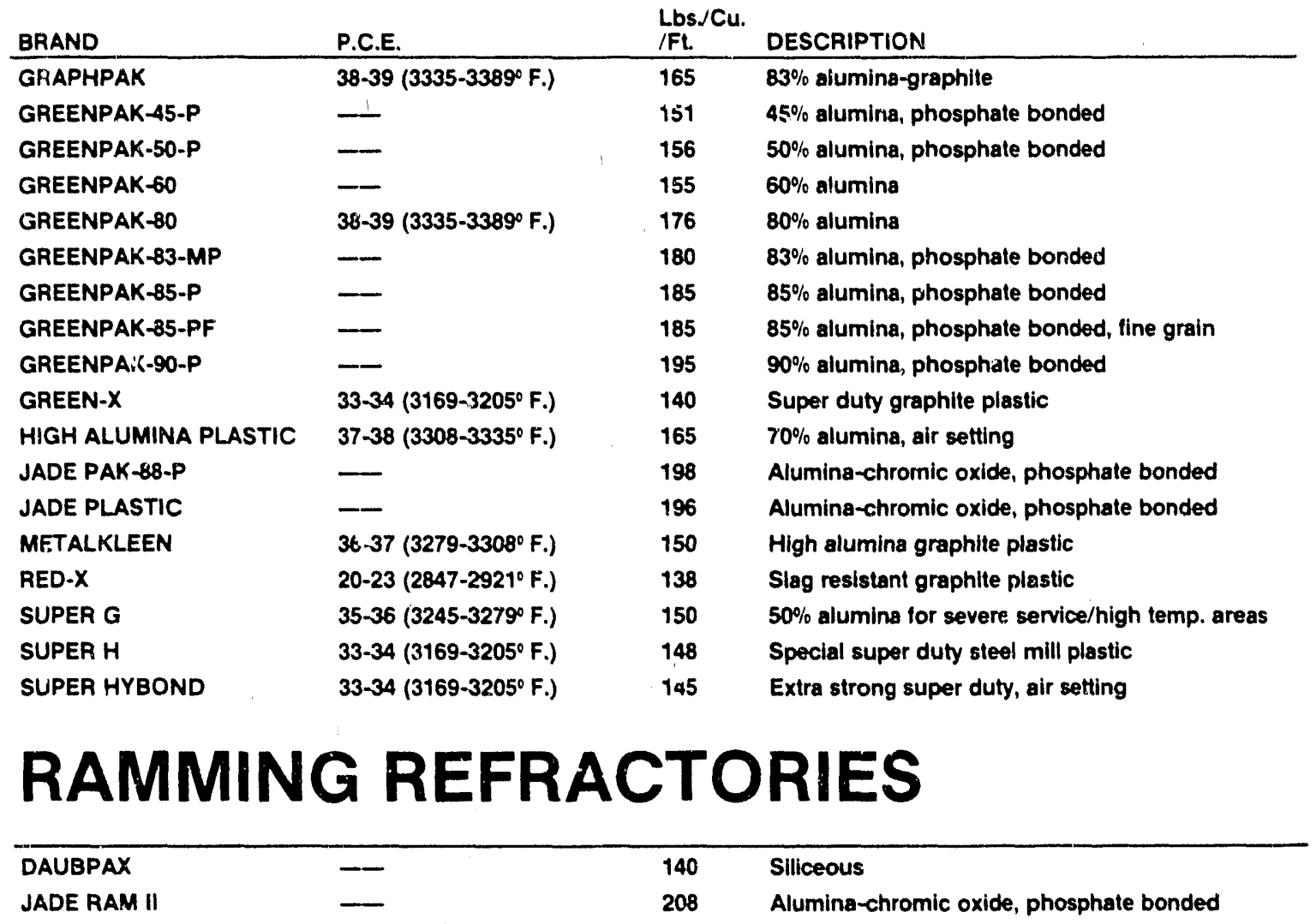

\section{PLUS PLASTICS}

\section{Fast Firing Capability}

The entire $i$ ie of A. P. Green regular plastics and GREENGUN plastics are available in the PLUS version, featuring an added ingredient that gives them a fast fire capability that can be translated into extra savings on many plastic jobs. PLUS plastics have proved their worth in all types of jobs throughot: the country. When your next plastic installation is approaching, inquire abou $A$. P. Green PLUS Plastics. Their extra dimension can bring you these benefits:

SHORTER HEAT-UP SCHEDULE . . . Capable of being heated faster, PLUS Plastics mean shorter heat-up schedules, reduced downtime. A normal plastic heat-up takes from 2-5 days to bring to operating temperature. PLUS Plastics can normally be brr.⿲ght to operating temperatures in less than 15 holirs.

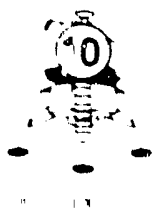


LESS FUEL USAGE ... Extensive fuel is necessary to follow the normal heat-up schedule of plastics. The greatly reduced heat-up time for PLUS Plastics translates to substantially less fuel usage and increased savings.

REDUCED LABOR COSTS ... High labor costs are associated with properly following the normal long plastic heat-up. Labor costs are reduced due to less personnel time spent on monitoring the shorter heat-up time of PLUS Plastics.

LESS B!-OATING, SHEETING, CRACKING . . . If a conventional plastic heat-uf schedule is exceeded, the result is excessive bloating, sheeting, and cracking ... harming the integrity of the lining and necessitating immediate repairs. Bloating, sheeting, and cracking are very remote with PLUS Plastic linings regardless of the heat-up rate used to bring the unit to operating temperature.

\section{GREENGUN}

\section{A Total System For Plastic Refractory Placement}

The GREENGUN System is an advanced installation method for placing plastic refractories. It features the advantages of a gunned lining - higher production rates, lower labor costs, less downtime - while producing a lining with excellent physical properties and good structural integrity.

The GREENGUN System combines the latest technology in gunning equipment, highly trained, professional installation crews, and a wide range of job-proved, scientifically developed products. The total result is a long-lasting, quality installation at a more economical installed cost. Ali GREENGUN materials are also available with Plus additives.

\section{- Fast, efficient material piacement \\ - Less manpower requirements \\ - Highly compacted, long-lasting linings \\ - Wide range of specially developed materials \\ - Less downtime and lost production}

BRAND
GREENGUN-45
GREENGUN-45 P
GREENGUN-45 X
GREENGUN-46
GREENGUN-50
GREENGUN-50 P
GREENGUN-53 XS
GREENGUN-60
GREENGUN-60X
GREENGUN-70
GREENGUN-70P
GREENGUN-80
GREENGUN-83 P
GREENGUN-83 X
GREENGUN-85 P
GREENG!UN-90 P
GREENGUN-JADE

BRAND

DISCRIPTION

Super duty fireclay

Super duty, phosphate bonded

Super duty, graphite

Super duty fireclay

$50 \%$ alumina

$50 \%$ alumina, phosphate bonc

Sillcon carbide, graphite

$60 \%$ alumina

$60 \%$ alumina, graphite

$70 \%$ alumina

$70 \%$ alumina, phosphate bonded $80 \%$ alumina

$83 \%$ aluinina, phosphate bonded $83 \%$ alumina, graphite

$85 \%$ alumina, phosphate bonded $90 \%$ alumina, phosphate bonded $88 \%$ alumina-chromic oxide,
phosphate bonded 


\section{CASTABLE REFRACTORIES}

Ain no other single source can a line of castable refractories be obtained that will match the Green Line of Castables. This complete line features products applied by all three recognized methods: troweling, pouring, and gunning. All A. P. Green castables can be applied where other products may be difficult to handle.

\begin{tabular}{|c|c|c|c|c|c|c|}
\hline \multirow{5}{*}{ 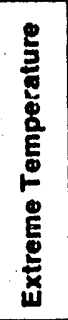 } & $\begin{array}{l}\text { Product } \\
\text { Brand } \\
\text { Name }\end{array}$ & $\begin{array}{l}\text { Mothod } \\
\text { of } \\
\text { Install. }\end{array}$ & $\begin{array}{l}\text { Max. } \\
\text { Service } \\
\text { Temp. }\end{array}$ & $\begin{array}{l}\text { Lba. } \\
\text { Reqd. } \\
\text { Per } \\
\text { Cu.Ft. }\end{array}$ & Type & Remarks \\
\hline & GREENCAST-94 & Pour & $3400^{\circ} \mathrm{F}$ & 163 & $94 \%$ Alumina & Extremely abrasion resistant \\
\hline & GREENCAST-97 & Pour & $3400^{\circ} \mathrm{F}$. & 158 & $97 \%$ Alumina & $\begin{array}{l}\text { For extreme temperature } \\
\text { fumace construction }\end{array}$ \\
\hline & KRUZITE CASTABLE & Pour & $3200^{\circ} \mathrm{F}$. & 150 & 74-78\% Alumina & Spall resistant, dense, strong \\
\hline & MIZZOU CASTABLE & Pour & $3000^{\circ} \mathrm{F}$. & 136 & $57-60 \%$ Alumina & Spall resistant, strong \\
\hline \multirow{5}{*}{ 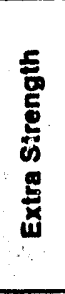 } & MC-30 & Pour & $3000^{\circ} \mathrm{F}$. & 145 & $64-670 ; 0$ Alumina & $\begin{array}{l}\text { Very coarse for thermal shock } \\
\text { and withstanding abrasion }\end{array}$ \\
\hline & STEELKON & Pour & $2800^{\circ} \mathrm{F}$. & 133 & $51-54 \%$ Alumina & Dense, strong, abrasion resistant \\
\hline & MC-25 & Pour & $2550^{\circ} \mathrm{F}$. & 125 & Fireclay & $\begin{array}{l}\text { Very coarse for thermal shock } \\
\text { and withstancing abrasion }\end{array}$ \\
\hline & LO-ABRADE & Pour & $2600^{\circ} \mathrm{F}$ & 133 & $54-57 \%$ Alumina & Resists abrasion and/or erosion \\
\hline & MC-22 & Pour & $2350^{\circ} \mathrm{F}$. & 125 & Fireclay & $\begin{array}{l}\text { Very coarse for thermal shock } \\
\text { and withstanding load and abrasion }\end{array}$ \\
\hline \multirow{8}{*}{$\begin{array}{l}0 \\
\frac{8}{0} \\
\frac{0}{0} \\
\frac{5}{0}\end{array}$} & GREENCAST-94 GR & Gun & $3400^{\circ} \mathrm{F}$. & 155 & $94 \%$ Alumina & $\begin{array}{l}\text { For resisting abrasion, erosion } \\
\text { and high temperatures }\end{array}$ \\
\hline & MIZZOU GR & Gun & $3000^{\circ} \mathrm{F}$ & 140 & $60-63 \%$ Alumina & Spall resistant, strong \\
\hline & STEELKON BF & Gun & $2800^{\circ} \mathrm{F}$. & 132 & 53-56\% Alumina & For blast furnace repair \\
\hline & GREENCAST-28 GR & Gun & $2800^{\circ} \mathrm{F}$. & 123 & Fireclay & For blast fumace repair \\
\hline & KS 4 V GR & Gun & $2600^{\circ} \mathrm{F}$. & 121 & Fireclay & For blast furnace repair \\
\hline & KS 4 GR & Gun & $2550^{\circ} \mathrm{F}$. & 125 & Fireclay & Dense, abrasion resistant \\
\hline & LO-ABRADE GR & Gun & $2600^{\circ} \mathrm{F}$. & 133 & $47-50 \%$ Alumina & Resists abrasion and/or erosion \\
\hline & GREENCAST-12 GA & Gun & $2200^{\circ} \mathrm{F}$. & 122 & Fireclay & $\begin{array}{l}\text { High strength and abrasion } \\
\text { resistance }\end{array}$ \\
\hline \multirow{5}{*}{$\frac{8}{8}$} & SUPER KAST-SET & Pour & $2800^{\circ} \mathrm{F}$. & 120 & Fireclay & $\begin{array}{l}\text { Resists vitrification, balanced } \\
\text { properties }\end{array}$ \\
\hline & KS-4V & Pour & $2600^{\circ} \mathrm{F}$. & 122 & Fireclay & Strong, abrasion resistant. \\
\hline & KAST-SET & Pour & $2700^{\circ} \mathrm{F}$. & 115 & Fireclay & Outstanding general purpose matl. \\
\hline & $\mathrm{KS}-4$ & Pour & $2550^{\circ} \mathrm{F}$. & 123 & Fireclay & Strong, dense, abrasion resistant \\
\hline & HYDROCRETE & Pouir & $2200^{\circ} \mathrm{F}$. & 125 & Fireclay & $\begin{array}{l}\text { High strength, resistant to carbon } \\
\text { monoxide atmospheres }\end{array}$ \\
\hline
\end{tabular}

\section{ULTRA-GREEN.....Ultralow Cement, High Strength Castables}

ULTRA-GREEN represents the new breed of ultralow cement, high strength, vibratable castables. A long list of impressive physical and chemical characteristics make these new generation materials ideal for numerous high temperature applications. The unique bond found in ULTRA-GREEN products gives them strength and hot load properties superior to regular low cemerit or conventional castables. Their low porosity enables them to better resist slag and hot metal penetration. In essence, properties of ULTRA-GREEN are equal or superior to fired brick of similar alumina composition, yet they are installed with the speed and ease of a vibratable castable.

ULTRA-GREEN is now available in three alumina contents:

\begin{tabular}{lccc} 
Product & $\%$ Alumina & Wt./Ft. & $\begin{array}{c}\text { Recommended } \\
\text { Temperature }\end{array}$ \\
\hline ULTRAA-GREENI 45 & $45 \%$ & 145 & $3000 \overline{0} \mathrm{~F}$. \\
ULTRA-GREEN 70 & $70 \%$ & 165 & $31000^{\circ} \mathrm{F}$. \\
ULTRA-GREEN 80 & $80 \%$ & 175 & $3200^{\circ} \mathrm{F}$. \\
& & &
\end{tabular}




\begin{tabular}{|c|c|c|c|c|c|}
\hline $\begin{array}{l}\text { Product } \\
\text { Brand } \\
\text { Name }\end{array}$ & $\begin{array}{l}\text { Method } \\
\text { of } \\
\text { Install. }\end{array}$ & $\begin{array}{l}\text { Max. } \\
\text { Service } \\
\text { Temp. }\end{array}$ & $\begin{array}{l}\text { Lbs. } \\
\text { Reqd. } \\
\text { Per } \\
\text { Cu.Ft. }\end{array}$ & Type & Remarks \\
\hline GREENCAST-97-L & Pour & $3300^{\circ} \mathrm{F}$. & 85 & $\begin{array}{l}\text { Insulating } \\
\text { Bubble Alumina }\end{array}$ & $\begin{array}{l}\text { For very high temperatures, resists } \\
\text { carbon monoxide disintegration }\end{array}$ \\
\hline KAST-O-LITE 30 & Pour & $3000^{\circ} \mathrm{F}$. & 84 & $\begin{array}{l}\text { Insulating } \\
\text { Aggregate }\end{array}$ & $\begin{array}{l}\text { For high temperatures, good strength, } \\
\text { replaces heavy and insulating brick }\end{array}$ \\
\hline KAST-O-LITE 30 GR & Gun & $3000^{\circ} \mathrm{F}$ & 98 & Insul. Aggregate & For high temperatures, good strength \\
\hline MC-28-L & Pour & $2800^{\circ} \mathrm{F}$. & 110 & Coar. Aggregate & Extra strength, coarse aggregate \\
\hline GREENCAST-26-L & Pour & $2600^{\circ} \mathrm{F}$. & 50 & $\begin{array}{l}\text { Insulating } \\
\text { Aggregate }\end{array}$ & $\begin{array}{l}\text { Low Iron, excellent for highly } \\
\text { reducing atmospheres }\end{array}$ \\
\hline KAST-O-LITE 25 & Pour & $2500^{\circ} \mathrm{F}$ & 82 & $\begin{array}{l}\text { Insulating } \\
\text { Aggregate }\end{array}$ & $\begin{array}{l}\text { Good strength, replaces heavy and } \\
\text { insulating firebrick }\end{array}$ \\
\hline KAST-O-LITE 25 GR & Gun & $2500^{\circ} \mathrm{F}$. & 90 & $\begin{array}{l}\text { Insulating } \\
\text { Aggregate }\end{array}$ & $\begin{array}{l}\text { Good strength, replaces heavy and } \\
\text { insulating firebrick }\end{array}$ \\
\hline VSL-50 & $\begin{array}{l}\text { Gun } \\
\text { Pour }\end{array}$ & $2300^{\circ} \mathrm{F}$ & $\begin{array}{l}60 \\
54\end{array}$ & $\begin{array}{l}\text { Insulating } \\
\text { Aggregate }\end{array}$ & $\begin{array}{l}\text { Low iron - excelient for use in highly } \\
\text { reducing atmospheres }\end{array}$ \\
\hline $\begin{array}{l}\text { CASTABLE } \\
\text { INSULATION NO. } 22\end{array}$ & Pour & $2200^{\circ} \mathrm{F}$. & 50 & $\begin{array}{l}\text { Insulating } \\
\text { Aggregate }\end{array}$ & $\begin{array}{l}\text { Good strength, low thermal } \\
\text { conductivity, low shrinkage }\end{array}$ \\
\hline $\begin{array}{l}\text { CASTABLE INSULA- } \\
\text { TION NO. } 22 \text { GR }\end{array}$ & Gun & $2200^{\circ} \mathrm{F}$. & 72 & $\begin{array}{l}\text { Insulating } \\
\text { Aggregate }\end{array}$ & $\begin{array}{l}\text { Light weight combined with good } \\
\text { strength, low rebound }\end{array}$ \\
\hline VSL-35 & $\begin{array}{l}\text { Gun } \\
\text { Pour }\end{array}$ & $2000^{\circ} \mathrm{F}$. & $\begin{array}{l}39 \\
29 \\
\end{array}$ & $\begin{array}{l}\text { Insulating } \\
\text { Aggregate }\end{array}$ & $\begin{array}{l}\text { Low thermal conductivity, } \\
\text { resistant to thermal shock }\end{array}$ \\
\hline $\begin{array}{l}\text { CASTABLE } \\
\text { BLOCK MIX }\end{array}$ & Pour & $1600^{\circ} \mathrm{F}$. & 21 & $\begin{array}{l}\text { Insulating } \\
\text { Aggregate }\end{array}$ & $\begin{array}{l}\text { Extra low thermal conductivity } \\
\text { block insulation in castable form }\end{array}$ \\
\hline
\end{tabular}

\section{Plus Castables..... Faster, Safer Heat-Ups}

All A. P. Green castable materials are available with job-proved PLUS additives. PLUS additions to castables give them Fast Fire Capability, reducing heat-up time drastically while greatly reducing the dangers of explosive spalling.

REDUCED CHANCES FOR EXPLOSIVE SPALLING . . Explosive spalling or severe cracking is almost nonexistent with PLUS Castables, regardless of the heat-up rate, thus giving additional insurance against the possibilty of injury to personnel or equipment.

BETTER THERMAL SHOCK RESISTANCE ... Job experience indicates that PLUS Castables have better thermal shock resistance than conventional castables when cyclic temperatures are involved.

LOWER LABOR COSTS ... Faster heat-up means reduced labor costs associated with monitoring the faster schedules.

FUEL SAVINGS ... The faster fire-in capability of PLUS Castables reduces the amount of fuel required for heat-up.

LESS DOWNTIME... Heat-ups can be reduced from 2-5 days to less than 15 hours. This faster schedule translates into reduced equipment downtime and less production losses.

\begin{tabular}{|c|c|c|c|c|}
\hline \multirow{8}{*}{$\frac{1}{0}$} & $\begin{array}{l}\text { Product Brand } \\
\text { Name }\end{array}$ & Description & $\begin{array}{l}\text { Lbs. Req. } \\
\text { Per Cu.Ft. }\end{array}$ & Remarks \\
\hline & GREENCOTE & Refractory maintenance & - & Applied as a prolective coating or patch \\
\hline & GREE $N K O N-26$ Plus & High strength, vibrating castable & 133 & $\begin{array}{l}\text { Outstanding hol strength for coke oven } \\
\text { doors, car top blocks }\end{array}$ \\
\hline & GREENKON-28 Plus & High strength, vibrating castable & 135 & $\begin{array}{l}\text { Outstanding hot strength for iron ladles, } \\
\text { forge furnaces }\end{array}$ \\
\hline & GREENKON-30 Plus & High strength, vibrating castable & 163 & $\begin{array}{l}\text { Outstanding hot strength for high } \\
\text { temperature burner ports, iron ladles }\end{array}$ \\
\hline & GUNWELD 50 & $\begin{array}{l}50 \% \text { alumina, hol or coid } \\
\text { gun mix }\end{array}$ & 120 & \multirow{3}{*}{$\begin{array}{l}\text { For hol or cold repairs with minimum } \\
\text { downtime or for complete linings. Can } \\
\text { be used with fireclay, sillca, nr high } \\
\text { alumina linings. }\end{array}$} \\
\hline & GUNWELD 70 & $\begin{array}{l}70 \% \text { alumina, hot or cold } \\
\text { gun mix }\end{array}$ & 138 & \\
\hline & GUNWELD 90 & $\begin{array}{l}90 \% \text { alumina }{ }_{2} \text { hot or cold } \\
\text { gun mix }\end{array}$ & 150 & \\
\hline
\end{tabular}

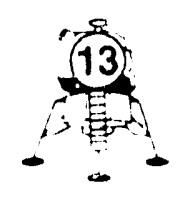




\section{A. P. GREEN INDUSTRIES, INC. \\ MEXICO, MISSOURI 65265 U.S.A:}

TENTATIVE TECHNICAL DATA

UITRA-GREEN 45

Ultra-low Cement Vibrating Castable

MAXIMUM RECOMMENDED TEMPERATURE

QUANTITY REQUIRED

QUANTITY IN PLACE

Cured and Then Dried at $220^{\circ} \mathrm{F}\left(105^{\circ} \mathrm{C}\right)$ Heated at $1500^{\circ} \mathrm{F}\left(815^{\circ} \mathrm{C}\right)$

APPARENT POROSITY - ASTM C20

Cured and Then Dried at $220^{\circ} \mathrm{F}\left(105^{\circ} \mathrm{C}\right)$ Heated at $1500^{\circ} \mathrm{F}\left(815^{\circ} \mathrm{C}\right)$ and Then Cooled --

WATER REQUIRED FOR MIXING

Per 100 Pounds $(45.4 \mathrm{~kg})$

MAXIMUM TIME FROM ADDING WATER TO PLACIING MATERIAI Minutes -

PERMANENT LINEAR CHANGE - ASTM CII3 and C865

Expansion or Shrinkage Cured and Then Dried at $220^{\circ} \mathrm{F}\left(105^{\circ} \mathrm{C}\right)$ Heated at $1500^{\circ} \mathrm{F}\left(815^{\circ} \mathrm{C}\right)$ and Then Cooled Heated at $2000^{\circ} \mathrm{F}\left(1095^{\circ} \mathrm{C}\right)$ and Then Cooled Heated at $2500^{\circ} \mathrm{F}\left(1370^{\circ} \mathrm{C}\right)$ and Then cooled Heated at $2910^{\circ} \mathrm{F}\left(1595^{\circ} \mathrm{C}\right)$ and then Cooled

MODULUS OF RUPTURE - ASTM C 133 and 6865

Cuzed and Then Dried at $220^{\circ} \mathrm{F}$ (105 $\mathrm{C}$ ) - Heated at $1500^{\circ} \mathrm{F}\left(815^{\circ} \mathrm{C}\right)$ and Then cooled -Heated at $2000^{\circ} \mathrm{F}\left(1095^{\circ} \mathrm{C}\right)$ and Then Cooled Heated at $2500^{\circ} \mathrm{F}\left(1370^{\circ} \mathrm{C}\right)$ and then cooled -

HOT MODULUS OF RUPTURE - ASTM C583 and ASTM 2865

rieated at $1500^{\circ} \mathrm{F}\left(815^{\circ} \mathrm{C}\right)$

Heated at $2000^{\circ} \mathrm{F}\left(1095^{\circ} \mathrm{C}\right)$

Heated at $2500^{\circ} \mathrm{F}\left(1370^{\circ} \mathrm{C}\right)$

COID CRUSHING STRENGTH - ASTM C133 and C865

Cured and Then Dried at $220^{\circ} \mathrm{F}\left(105^{\circ} \mathrm{C}\right)$ heated at $1500^{\circ} \vec{F}\left(815^{\circ} \mathrm{C}\right)$ and Then Cooled -Hearea at $2000^{\circ} \mathrm{F}\left(1095^{\circ} \mathrm{C}\right)$ and Then Cooled liejted at $2500^{\circ} \mathrm{F}\left(1370^{\circ} \mathrm{C}\right)$ and Then Cooled -

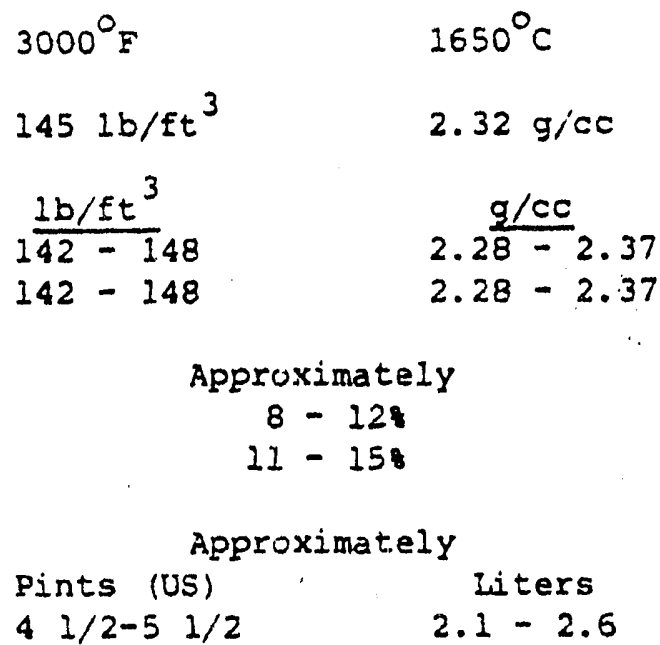

20

Nil

$0-0.58 \operatorname{sh} x$

$0.2-0.82 \operatorname{sh} x$

$0.7 \operatorname{sh} x-0.3 \exp$

$1.0-2.58 \mathrm{exp}$

$\begin{array}{rr}\frac{1 \mathrm{~b} / \mathrm{in}^{2}}{1000-2000} & \frac{\mathrm{kg} / \mathrm{cm}^{2}}{70-140} \\ 1800-2800 & 125-195 \\ 1500-2800 & 105-195 \\ 800-1500 & 55-105\end{array}$

$2200-3800$

$155-265$

$2500-3500$

$175-245$

$600-1200$

$40-85$

$\begin{array}{rl}5000-10000 & 350-705 \\ 8000-15000 & 560-1055 \\ 10000-16000 & 705-1125 \\ 7000-13000 & 490-915\end{array}$


ABRASION LOSS - ASTM C70

Heated at $\left.1500^{\circ} \mathrm{F}(8 \mathrm{~L}) \mathrm{C}\right)$ and Then cooled --

Heated at $2500^{\circ} \mathrm{F}\left(13,10^{\circ} \mathrm{C}\right)$ ans when cooled -

$$
\begin{aligned}
& 7=\frac{c=}{20} \\
& 5-9
\end{aligned}
$$

Trace

$\begin{array}{cc}\frac{\text { Btu-in }}{\mathrm{ft} h r} \mathrm{~F} & \frac{\mathrm{kgel-m}}{\mathrm{m} h r \mathrm{C}} \\ 6.19 & 0.77 \\ 7.34 & 0.91 \\ 8.49 & 1.05 \\ 9.63 & 1.19 \\ 10.78 & 1.34 \\ 11.93 & 1.48\end{array}$

CHEMICAL ANALYSIS

Calcired Basis

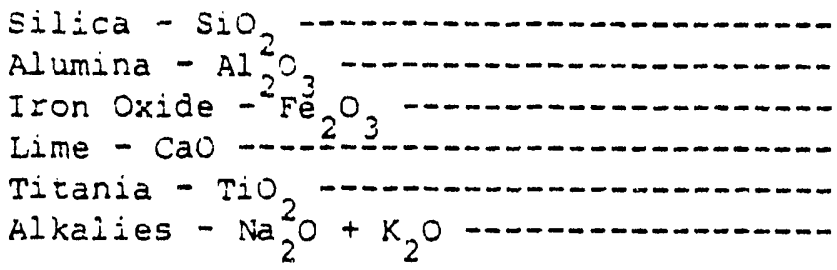

$$
\begin{gathered}
44.0-50.08 \\
44.0-50.08 \\
1.0-1.68 \\
0.7-1.08 \\
2.5-3.58 \\
0.4-0.78
\end{gathered}
$$

These results cannot be taken as maximum or minimum requirements for specification purposes. 
A. P. GREEN INDUSTRIES, INC.

MEXICO, MISSOURI 65265 U.S.A.
WILC BE VERY SIMILAX TO R-8009 witIUH 15 ULTKA GRRFN-STA'S FIRLD TRST
PREOTCESSOR.

LIMITED DATA SHEET

$\underline{R-8009}$

Ultra-Low Cement vibrating Castable
MAXIMUM RECOMMENDED TEMPERATURE

QUANTITY REQUIRED

QUANTITY IN PLACE

Cured and Then Dried at $220^{\circ} \mathrm{F} \quad\left(105^{\circ} \mathrm{C}\right)$

Heated at $1500^{\circ} \mathrm{F}\left(815^{\circ} \mathrm{C}\right)$

APPARENT POROSITY - ASTM C20

Cured and Then Dried at $220^{\circ} \mathrm{F} \quad\left(105^{\circ} \mathrm{C}\right) \ldots . .$.

Heated at $1500^{\circ} \mathrm{F}\left(\varepsilon 15^{\circ} \mathrm{C}\right)$ and Then coolea -.

WATER REQUIRED FOR MIXING

Per 100 Pounds $(45.4 \mathrm{~kg})$

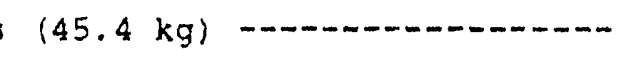

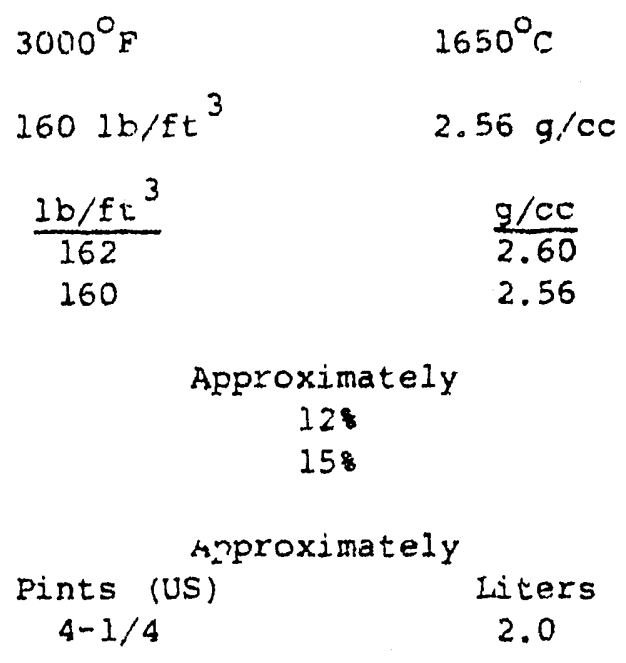

Approximately

128

158

Approximately

$\begin{array}{cc}\text { Pints (US) } & \text { Liters } \\ 4-1 / 4 & 2.0\end{array}$

20

Nil

$0-0.3 \% \exp$

$0-0.52 \mathrm{exp}$

$0-1.08 \mathrm{exp}$

$0-1.3 \mathrm{exp}$

$0-1.38 \mathrm{exp}$

$\begin{array}{cc}\frac{1 \mathrm{~b} / \mathrm{in}^{2}}{2000} & \frac{\mathrm{kg} / \mathrm{cm}^{2}}{140} \\ 1500 & 105 \\ 1200 & 85 \\ 1400 & 100\end{array}$

$1900 \quad 135$

$2400 \quad 170$

$650 \quad 45$

$10000 \quad 705$

$10000 \quad 705$

$10000 \quad 705$

$9500 \quad 670$ 
ABRASION LOSS - ASTM C704

Heat at $1500^{\circ} \mathrm{F}\left(815^{\circ} \mathrm{C}\right)$ and then cooled -..-

Heat at $2500^{\circ} \mathrm{F}\left(1370^{\circ} \mathrm{C}\right)$ and Then Cooled -.-

100 HOUR HOT LOAD TEST - ASTM C16

Deformation at $2600^{\circ} \mathrm{g}\left(1425^{\circ} \mathrm{C}\right)$

CREEP TEST $\left(1350^{\circ} \mathrm{C}\right.$ at $\left.2 \mathrm{~kg} / \mathrm{cm}^{2}\right)$

20-50 Wour

PARTICLE SIZE - AS'SM C92

Retained on 4 Mesh Tyler screen (4.7 mm opening)

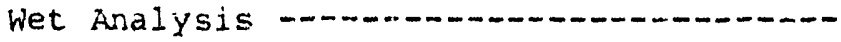

THERMAL CONDUCTIVITY

At a Mean Temperature of

$\begin{aligned} 400^{\circ} \mathrm{F} & \left(205^{\circ} \mathrm{C}\right) \\ 800^{\circ} \mathrm{F} & \left(425^{\circ} \mathrm{C}\right) \\ 1200^{\circ} \mathrm{F} & \left(650^{\circ} \mathrm{C}\right) \\ 1600^{\circ} \mathrm{F} & \left(870^{\circ} \mathrm{C}\right) \\ 2000^{\circ} \mathrm{F} & \left(1095^{\circ} \mathrm{C}\right) \\ 2400^{\circ} \mathrm{F} & \left(1315^{\circ} \mathrm{C}\right)\end{aligned}$

CHEMICAL ANALYSIS

Calcined Bäsis

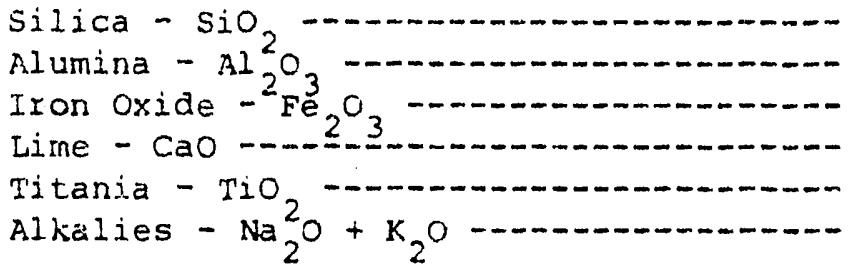

$6 \stackrel{C C}{=} 10$
$6-10$

18

0.078 subsidence

Trace

$\begin{array}{lc}\frac{B t y-i n}{f t h r} F & \frac{k g a l-m}{m^{2} h r C} \\ 10.88 & 1.35 \\ 11.44 & 1.42 \\ 11.97 & 1.48 \\ 12.47 & 1.55 \\ 12.94 & 1.60 \\ 13.38 & 1.66\end{array}$

These results cannot be taken as maximum or minimum requirements for specification purposes.

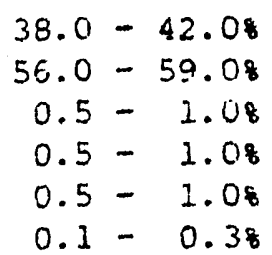

$38.0-42.08$

$56.0-59.08$

$0.5-1.08$

$0.5-1.08$

$0.1-0.38$ 


\section{A. P. GREEN REFRACTORIES CO.}

MEXICO. MISSOUAI 65265 U.S.A.

TECHISCAL DATA

DMPIRE DP

\section{Zigh Duty, Dry Press, 9" and 3" Strics Pire Clay Brick Maoufactured at Mexico, Missouri}

$$
\begin{gathered}
32-33 \\
3123-31699^{\circ} \mathrm{C} \\
1717-1743^{\circ} \mathrm{C}
\end{gathered}
$$

REHzat (Pe twanent Ligeer Change) - ASTM Cl13

Contraction or Expanai ja at $2550^{\circ} \mathrm{g}\left(1400^{\circ} \mathrm{C}\right)$ $0.2 \pi$ Exp.

$0.2-2.0 \%$

$0.5-4 x$

$18-22 \pi$

$3.5-11 \%$

$8 / c c$

$2.05-2.15$

$\mathrm{kg} / \mathrm{cm}^{2}$

$42-70$

$141-211$

CHEMICAL ARALYSIS

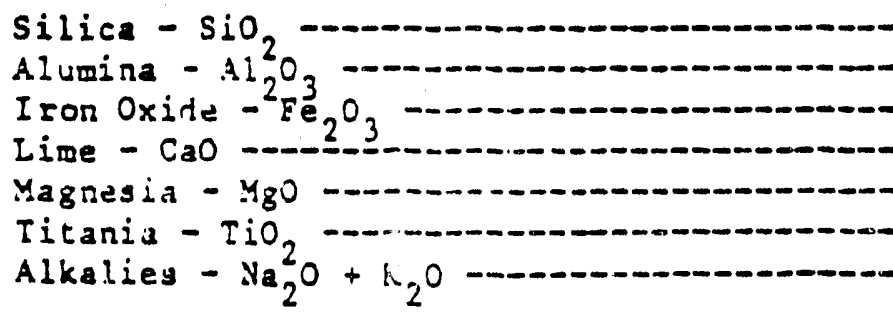

$55.0-58.0 \%$

37.0. -40.07

$1.0-2.57$

$0.1-0.6 \%$

$0.1-0.67$

$1.0-2.0 \%$

$0.5-1.57$

The test data shown above are based on average results of control tegts on g" brick and ase subject to norral variation on individual tests. These results cannot be taken as maximum or minimum requirements for specification purposes.

Form TD $42-5$

(5) 
A. P. GREEN INDUSTRIES, INC.

MEXICO, MISSOURI 65265 U.S.A.

LIMITED DATA SHEET

GREENDAK-83-MP

High Alumina, Phosphate Bonded, Plastic Refractory

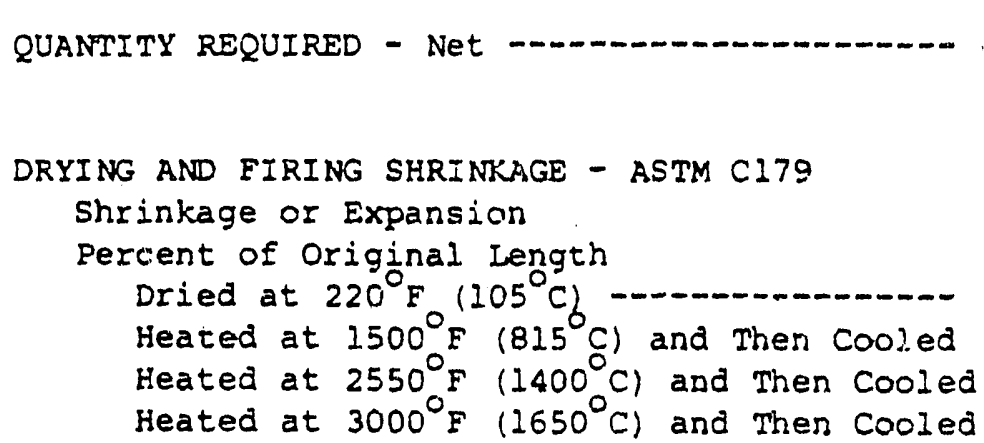

MODUIUS OF RUPTURE - ASTM C491

Dried at $220^{\circ} \mathrm{F}\left(105^{\circ} \mathrm{C}\right)$

Heated at $1500^{\circ} \mathrm{F}\left(815^{\circ} \mathrm{C}\right)$ and Then cooled --

heated at $2550^{\circ} \mathrm{F}\left(1400^{\circ} \mathrm{C}\right)$ and Then Cooled -

PARTICLE SIZE - ASTM C92

Retained on 6 Mesh Tyler Screen (3.33 mm opening)

wet Aralysis

CHEMICAL ANALYSIS

Calcined Basis

Silica - $\mathrm{SiO}_{2}$

Alumina - $\mathrm{Al}_{2}^{2} \mathrm{O}_{3}$

Iron Oxide ${ }^{2} \mathrm{Fe}_{2}(1-\ldots$

Lime - CaO -...

Magnesia - MgO ...-

Titania - TiO ,

Alkalies - $\mathrm{Na}_{2}^{2} \mathrm{O}+\mathrm{K}_{2} \mathrm{O}$

Phosphorous Pentoxide $-\mathrm{P}_{2} \mathrm{O}_{5} \ldots$
$1 b /$ It $^{3}$

181

$g / \mathrm{Cc}$

2.88

Less Than 68

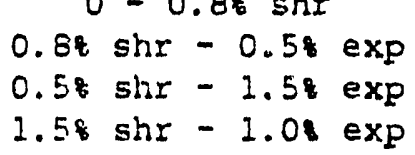

$1 b / i n^{2}$

900

$\mathrm{kg} / \mathrm{cm}^{2}$

1100

These results cannot be taken as maximum or minimum requirements for specification purposes. 
TECHNICAL DATA

IO-ABRADE

High Strength, Abrasion Resistant Castable

MAXIMUM RECOMMENDED TEMPERATURE

QUANTITY REQUIRED - Net

QUANTITY IN PLACE

Cured and Then Dried at $220^{\circ} \mathrm{F}\left(105^{\circ} \mathrm{C}\right)$

Heated at $1500^{\circ} \mathrm{F}\left(815^{\circ} \mathrm{C}\right)$ and cooled

WATER REQUIRED FOR MIXING

Per 1.00 Pounds $(45.4 \mathrm{~kg})$

MAXIMUM TIME FROM ADDING WATER TO PLACING MATERIAL

Minutes -

PERMANENT LINEAR CHANGE - ASTM C 113 and C865

Expansion or Shrinkage

Cured anc wen Dried at $220^{\circ} \mathrm{F}\left(105^{\circ} \mathrm{C}\right)$ heated at $1000^{\circ} \mathrm{F}\left(540^{\circ} \mathrm{C}\right)$ and Then cooled Heated at $1500^{\circ} \mathrm{F}\left(815^{\circ} \mathrm{C}\right)$ and Then Couled Heated at $2000^{\circ} \mathrm{F}\left(1095^{\circ} \mathrm{C}\right)$ and then cooled Heated at $2300^{\circ} \mathrm{F}\left(1260^{\circ} \mathrm{C}\right)$ and Then Cooled

MODULUS OF RUPTURE - ASTM CI33 and C865

Cured and Then Dried at $220^{\circ} \mathrm{F}\left(105^{\circ} \mathrm{C}\right)$ Heated at $1500^{\circ} \mathrm{F}\left(815^{\circ} \mathrm{C}\right)$ and Then Cooled -.. Heated at $2000^{\circ} \mathrm{F}\left(1095^{\circ} \mathrm{C}\right)$ and Then Cooled -.-

COLD CRUSHING STRENGTH - ASTM C 133 and C865

Cured and Then Dried at $220^{\circ} \mathrm{F}\left(105^{\circ} \mathrm{C}\right)$ Heated at $1500^{\circ} \mathrm{F}\left(815^{\circ} \mathrm{C}\right)$ and Then Cocled -..Heatea at $2000^{\circ} \mathrm{F}\left(1095^{\circ} \mathrm{C}\right)$ and Then Cooled ...

PARTICLE SIZE - ASTM C92

Retained on 4 Mesh Tyler Screen (4.70 nm opening)

Wet Analysis

ABRASION LOSS - ASTM C704

Heated at $1500^{\circ} \mathrm{F}\left(815^{\circ} \mathrm{C}\right)$ and then cooled -... $2600^{\circ} \mathrm{F} \quad 1425^{\circ} \mathrm{C}$

$132 \mathrm{Ib} / \mathrm{ft}^{3} \quad 2.11 \mathrm{~g} / \mathrm{Cc}$

$1 b / f t^{3} \quad g / c c$

$135-143 \quad 2.16-2.29$

128-136 2.05-2.18

Approximately

1 i/4 gallons (US) 4.7 iters

15

$\mathrm{Nil}$

$0-0.38$ shr

$0-0.38 \operatorname{sh} r$

$0-0.58$ shr

$0.3-1.2 \% \operatorname{shr}$

$\begin{array}{ll}1 \mathrm{~b} / \mathrm{in}^{2} & \mathrm{~kg} / \mathrm{cm}^{2} \\ 1200-1600 & 84-112 \\ 1000-1400 & 70-98 \\ =00-700 & 21-49\end{array}$

$5500-10000$

$387-703$

3900-8000

$274-562$

$3300-7000$

$232-492$

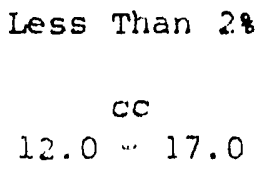

Less Than 28

$12.0 \cdots 17.0$ 


\section{IO-ABRADE}

THERMAL CONDUCTIVITY

at a Mean Temperature of $400^{\circ} \mathrm{F}\left(205^{\circ} \mathrm{C}\right)$

$800^{\circ} \mathrm{F} \quad\left(425^{\circ} \mathrm{C}\right)$

$1200^{\circ} \mathrm{F} \quad\left(650^{\circ} \mathrm{C}\right)$

$1600^{\circ} \mathrm{F} \quad\left(870^{\circ} \mathrm{C}\right)$ $2000^{\circ} \mathrm{F} \quad\left(1095^{\circ} \mathrm{C}\right)$

CHEMICAL ANALYSIS

Calcined Basis

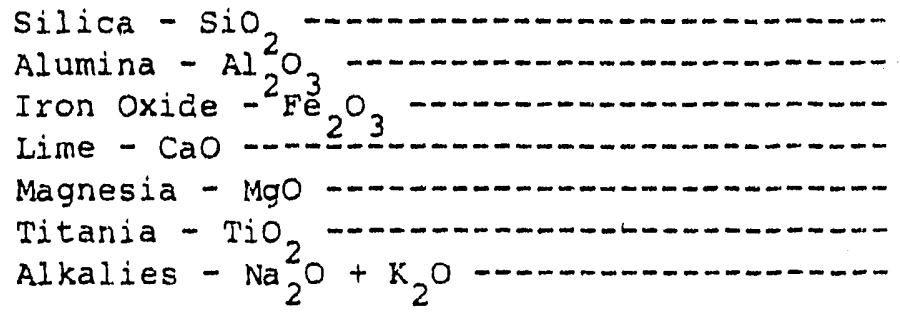

$\frac{\text { Bty-in }}{\mathrm{ft} \mathrm{t}^{2} \mathrm{hr}} \mathrm{F}$

5.60

6.10

6.17

6.21

6.46 kgal -m

0.69

0.76

0.77

0.77

0.80

The test data show above are based on average results of control tests and are subject to normal variation or individual tests. These results cannot be taken as maximum or minimum requirements for specification purposes. 
COMBUSTION ENGINEERING

(NOW PREMIER) 


\section{BOILEF}

REFRACTORIES:

Technical Data

and Information

\section{The importance of proper refractcry product selection.}

As in all industrial applications, the proper selec. tion of refractory products depends on a variety of operational and environmental factors. Equipment processes and conditions are different between individual power generating systems. Such factors as fuel chemistry, service temperatures and operating practice have a direct bearing on refractory requirements.

It is important to select the appropriate refractory product so that a complete refractory system is incorporated into an individual power generating system. Combustion Engineering manufactures a broad range of castables, plastics, mortars and insulating refractory products designed specifically for power generating systems.

Comburtion Engineering sales representatives combine power generating expertise with an excellent knowledge of refractory technology. Your C.E sales representative should always be consulted before final specifications and ordering of refractory prod. ucts and materials.

\section{PLAstics}

\begin{tabular}{|c|c|c|c|c|c|c|c|c|c|}
\hline \multirow[b]{2}{*}{ Product } & \multirow{2}{*}{$\begin{array}{l}\text { Recommended } \\
\text { Max. Senvice } \\
\text { Temp } \\
\left.{ }^{\circ} \mathrm{F}\right)\end{array}$} & \multirow{2}{*}{$\begin{array}{l}\text { Ory } \\
\text { Material } \\
\text { Requirert } \\
(\text { th.tth }\end{array}$} & \multirow{2}{*}{$\begin{array}{l}\text { Modulus of } \\
\text { Rupture } \\
\text { (ib. } 1 \text { in? } \\
\text { at 230\% } \\
\end{array}$} & \multirow[t]{2}{*}{$\begin{array}{l}\text { \%o Permanent } \\
\text { Linear Change } \\
\text { at } 1000^{\circ}\end{array}$} & \multicolumn{2}{|c|}{$\begin{array}{c}\text { Therrinal } \\
\text { Conductivity } \\
\text { (Btu } \rightarrow \text { in.me. } \\
\text { H? of }\end{array}$} & \multicolumn{2}{|c|}{$\begin{array}{l}\text { Chernical Aralysis } \\
(96 \text { Calcined Basis) }\end{array}$} & \multirow[b]{2}{*}{ Bond Type } \\
\hline & & & & & $500^{\circ} \mathrm{F}$ & $2000^{\circ} \mathrm{F}$ & $\mathrm{Al}_{2} \mathrm{O}_{3}$ & $\mathrm{SlO}_{2}$ & \\
\hline 90.RAM HS & 3100 & 185 & 1080 & -0.6 & 19.8 & 15.4 & 93.4 & 2.7 & Chemical \\
\hline 90-RAM" PC & 3100 & 183 & 950 & -1.0 & 14.0 & 16.5 & 91.5 & 4.3 & Chemical \\
\hline BLU-AAM! HS & 3100 & 171 & 1130 & -0.2 & 10.1 & 9.0 & 72.8 & 20.7 & Chemica \\
\hline WASP 60 & 2900 & 156 & 505 & -0.4 & 5.0 & 7.0 & 51.4 & 41.6 & Chemica \\
\hline RAMTITE' 25 & 2900 & 150 & 108 & -0.7 & 6.6 & 7.9 & 45.5 & 51.0 & Heat \\
\hline WASPI 30 & 2550 & 150 & 450 & -0.7 & 6.6 & 7.9 & 42.5 & 49.2 & Chemical \\
\hline $\begin{array}{l}\text { EMERALD } \\
\text { RAM" HS }\end{array}$ & 3400 & 201 & 1360 & -0.2 & 20.0 & 14.2 & 85.1 & \begin{tabular}{|c|}
10.0 \\
$\left(\mathrm{C}_{2} \mathrm{O}_{3}\right)$ \\
\end{tabular} & C \\
\hline
\end{tabular}

\section{DENSE CASTABLES}

\begin{tabular}{|c|c|c|c|c|c|c|c|c|c|}
\hline Product & $\begin{array}{c}\text { Recommended } \\
\text { Max. Service } \\
\text { Ternp } \\
\left({ }^{\circ} \mathrm{F}\right)\end{array}$ & $\begin{array}{c}\text { Dry } \\
\text { Material } \\
\text { Required } \\
\left(1 \mathrm{~b} . / \mathrm{tt}^{3}\right)\end{array}$ & $\begin{array}{c}\text { Modulus of } \\
\text { Rupture } \\
\text { (Ib./In?) } \\
\text { at } 230^{\circ} \mathrm{F}\end{array}$ & $\begin{array}{c}\% \text { Permanent } \\
\text { Linear Change } \\
\text { at } 1000^{\circ} \mathrm{F}\end{array}$ & $\begin{array}{l}\text { The } \\
\text { Cond } \\
\text { (Btu- } \\
\text { tt? } \\
500^{\circ} \mathrm{F}\end{array}$ & $\begin{array}{l}\text { Irmal } \\
\text { uctivity } \\
\text { in./hr. } \\
\text { F) } \\
1500^{\circ} \mathrm{F}\end{array}$ & $\begin{array}{l}\text { Chemi } \\
(\% \% \mathrm{Cal} \\
\mathrm{Al}_{2} \mathrm{O}_{3}\end{array}$ & $\begin{array}{l}\mathrm{Cal} \text { Ana } \\
\mathrm{cined} \mathrm{B} \\
\mathrm{CaO}\end{array}$ & $\begin{array}{l}\text { alysis } \\
\text { Basis) } \\
\mathrm{Fe}_{2} \mathrm{O}_{3}\end{array}$ \\
\hline $\begin{array}{l}\text { CASTABLE } \\
141 . A^{\circ}\end{array}$ & 3200 & 165 & 1100 & -0.1 & 11.2 & 9.9 & 97.0 & 2.7 & - \\
\hline $\begin{array}{l}\text { CEACAST: } \\
17\end{array}$ & 3090 & 164 & - & -0.1 & - & 8.5 & 85.3 & 5.3 & 1.7 \\
\hline $\begin{array}{l}\text { CERCAST } \\
\text { HT }\end{array}$ & 2900 & 144 & - & -0.1 & 66 & 8.0 & 55.9 & 4.5 & 0.9 \\
\hline $\begin{array}{l}\text { MOLDIT: } \\
\text { CHROME }\end{array}$ & 2900 & 196 & 550 & - & 6.3 & 8.7 & $\begin{array}{c}40.5 \\
\left(\mathrm{Cr}_{2} \mathrm{O}_{3}\right)\end{array}$ & 3.9 & 23.2 \\
\hline $\begin{array}{l}\text { CERCAST }{ }^{\square} \\
\text { SUPER LI }\end{array}$ & 2700 & 142 & - & -0.1 & 68 & 8.1 & 50.5 & 6.8 & 1.2 \\
\hline $\begin{array}{l}\text { HOT TOP } \\
\text { MOLDIT. }\end{array}$ & 2600 & 129 & 1210 & -02 & 49 & 5.6 & 491 & 8.2 & 12 \\
\hline $\begin{array}{l}M C: D I T \\
D_{L}\end{array}$ & 2450 & 118 & 975 & 01 & 59 & 42 & 457 & 121 & 2.8 \\
\hline MOLDIT'D & 2400 & 118 & $4 \div$ & 01 & 59 & 42 & 397 & 133 & 77 \\
\hline FSC. $5^{\prime \prime}$ & 2400 & 105 & sin & $-0^{\circ}$ & $\therefore !$ & 48 & 344 & 77 & 01 \\
\hline AR. $153^{\circ}$ & 2350 & 14 & $1:$ & $-1 !$ & $\vdots:$ & 0.6 & 562 & 65 & 06 \\
\hline
\end{tabular}

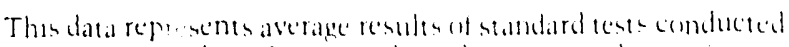

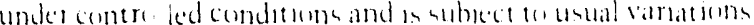

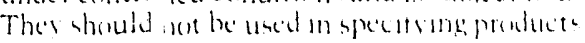




\section{INSULATING CASTABLES}

\begin{tabular}{|c|c|c|c|c|c|c|c|c|c|}
\hline Product & $\begin{array}{c}\text { Recom- } \\
\text { mended } \\
\text { Max. } \\
\text { Service } \\
\text { Terrp } \\
\text { (F) }\end{array}$ & \begin{tabular}{|c|} 
\\
Dry \\
Matenal \\
Requited \\
$\left(1 \mathrm{~b} . / \mathrm{th}^{3}\right)$
\end{tabular} & $\begin{array}{c}\text { Mudulus } \\
\text { of } \\
\text { Rupture } \\
\text { (ib. } / \mathrm{nn}^{2} \text { ) } \\
\text { at } 230^{\circ} \mathrm{F}\end{array}$ & $\mid \begin{array}{c}\% \text { Perm. } \\
\text { aneni } \\
\text { Linear } \\
\text { Change } \\
\text { at } 1000^{\circ} \mathrm{F}\end{array}$ & $\begin{array}{l}\text { The } \\
\text { Cordt } \\
\text { (Btu } \\
500^{\circ} \text { of }\end{array}$ & $\begin{array}{l}\text { imal } \\
\text { ctlivity } \\
\text {-in./hr } \\
\text { of } \\
1500^{\circ} \mathrm{F}\end{array}$ & $\begin{array}{r}\mathrm{Ch} \\
\mathrm{A} \\
\mathrm{Al} \mathrm{C}_{2} \mathrm{O}_{3}\end{array}$ & $\begin{array}{l}\text { hemica } \\
\text { unalysis } \\
\text { Calcin } \\
\text { Basis) } \\
\text { (CaO }\end{array}$ & $\begin{array}{l}\mathrm{al} \\
\text { is } \\
\mathrm{ned} \\
\mathrm{He}_{2} \mathrm{O}_{3}\end{array}$ \\
\hline $\begin{array}{l}\text { LITE } \\
\text { WATE: } 80\end{array}$ & 2500 & 80 & 345 & -0.1 & 3.9 & 2.2 & 47.0 & 11.9 & 1.9 \\
\hline \begin{tabular}{l|} 
LITE \\
WATE" 70
\end{tabular} & 2300 & 78 & 450 & -0.2 & 30 & 2.3 & 33.6 & 12.4 & 7.2 \\
\hline \begin{tabular}{|l|} 
LITE \\
WATE' 58
\end{tabular} & 2300 & 58 & 200 & -0.3 & 2.7 & 1.9 & 34.0 & 180 & 8.8 \\
\hline \begin{tabular}{|l|} 
LITE \\
WATE: 50
\end{tabular} & 1800 & 42 & 130 & -0.5 & 13 & 2.0 & 19.4 & 149 & 3.6 \\
\hline \begin{tabular}{|l|l|} 
CER & \\
LITE' 18
\end{tabular} & 1800 & 20 & 26 & $-0.1^{*}$ & 0.8 & 1.1 & 25.5 & 13.5 & 7.7 \\
\hline
\end{tabular}

MORTARS AND INSULATION

\begin{tabular}{|c|c|c|c|c|}
\hline Product & $\begin{array}{l}\text { Recommended } \\
\text { Maximum } \\
\text { Service } \\
\left.\text { Temp. ( }{ }^{\circ} \mathrm{F}\right)\end{array}$ & $\begin{array}{l}\cdot \\
\text { Density } \\
\left(1 \mathrm{~b} . / \mathrm{ft} \mathrm{t}^{3}\right)\end{array}$ & $\begin{array}{r}\text { The } \\
\text { Conid } \\
\text { Btu - in } \\
500^{\circ} \mathrm{F}\end{array}$ & $\begin{array}{l}\text { mal } \\
\text { crivity } \\
\left.\text { ht. } \mathrm{ft}^{\circ \circ} \mathrm{F}\right) \\
1000^{\circ} \mathrm{F} \\
\end{array}$ \\
\hline $\begin{array}{l}\text { SUPER \#3000' } \\
\text { MORTAR }\end{array}$ & 3000 & 155 & 5.2 & 5.8 \\
\hline $\begin{array}{l}\text { UTILITY FINISH- } \\
\text { ING CEMENT }\end{array}$ & 1200 & 45 & 0.7 & 1.1 \\
\hline $\begin{array}{l}\text { SUPER } \\
\text { STICTITE"w }\end{array}$ & 1800 & 32 & 0.7 & 1.3 \\
\hline $\begin{array}{l}\text { POURABLE } \\
\text { INSULATION }\end{array}$ & 1200 & 35 & 1.1 & 1.2 \\
\hline GRIPTEX ${ }^{3}$ BLOCK & 1800 & 15 & 0.5 & 0.8 \\
\hline $\begin{array}{l}\text { CALCINED } \\
\text { DIATOMACEOUS } \\
\text { SILICA BLOCK } \\
\end{array}$ & 2000 & 25 & 0.6 & 0.8 \\
\hline $\begin{array}{l}\text { VERMICULITE } \\
\text { INSULATING } \\
\text { BLOCK }\end{array}$ & 2000 & 25 & 0.6 & 0.8 \\
\hline $\begin{array}{l}\text { CER.WOOL } \\
\text { BLANKET LT } \\
\text { BLANKET RT } \\
\text { BLANKET HT } \\
\end{array}$ & $\begin{array}{l}1900 \\
2400 \\
2700 \\
\end{array}$ & $\begin{array}{l}4.6 .8 \\
4.6 .8 \\
4.6 .8 \\
\end{array}$ & $\begin{array}{l}0.4 \\
0.4 \\
0.4 \\
\end{array}$ & $\begin{array}{l}1.0 \\
1.0 \\
1.0 \\
\end{array}$ \\
\hline $\begin{array}{l}\text { CER-WOOLE } \\
\text { WET WRAP }\end{array}$ & 2100 & 24 & 0.5 & 0.9 \\
\hline $\begin{array}{r}\text { THERMOTECT } \\
\text { FIBER BOARD } \\
\text { A BOARD } \\
\text { RT BOARD } \\
\text { HT BOARD } \\
\end{array}$ & $\begin{array}{l}2300 \\
2200 \\
2700 \\
\end{array}$ & $\begin{array}{l}28 \\
22 \\
20 \\
\end{array}$ & $\begin{array}{l}0.9 \\
0.7 \\
0.7\end{array}$ & $\begin{array}{l}1.1 \\
0.8 \\
0.8 \\
\end{array}$ \\
\hline
\end{tabular}

\section{Power Systems}

Combustion Engineering, Inc.

$\because 000$ Prospect Hill Road

Windsor, CT 06095-0500

Phone: (203) 688-1911

TWX: 99297

\section{C-E Refractories}

Combustion Engineering, Inc.

P.O. Box 828

Valley Forge, PA 19482

Phone: (215) 337-1100

TWX: 510-660-4837

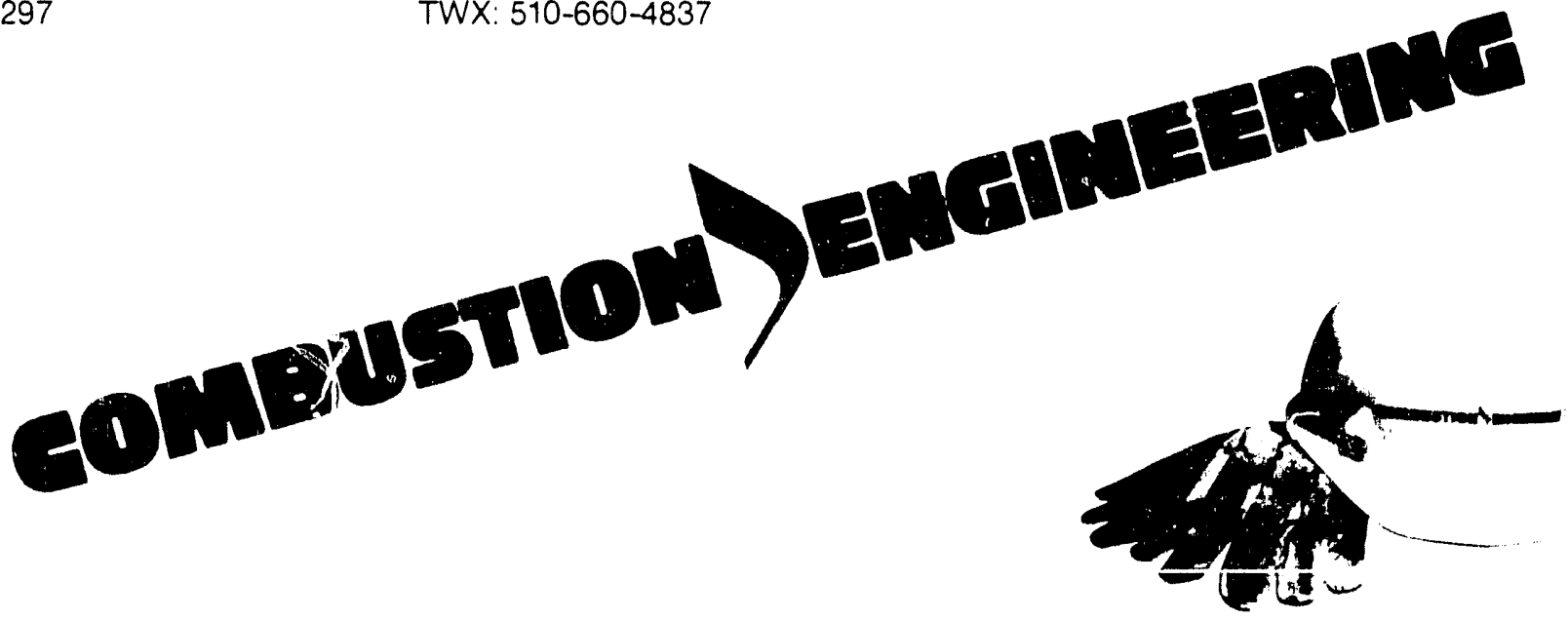




\section{Alumina-Silica Castables and \\ Gunning Refractories... \\ Technical Data}

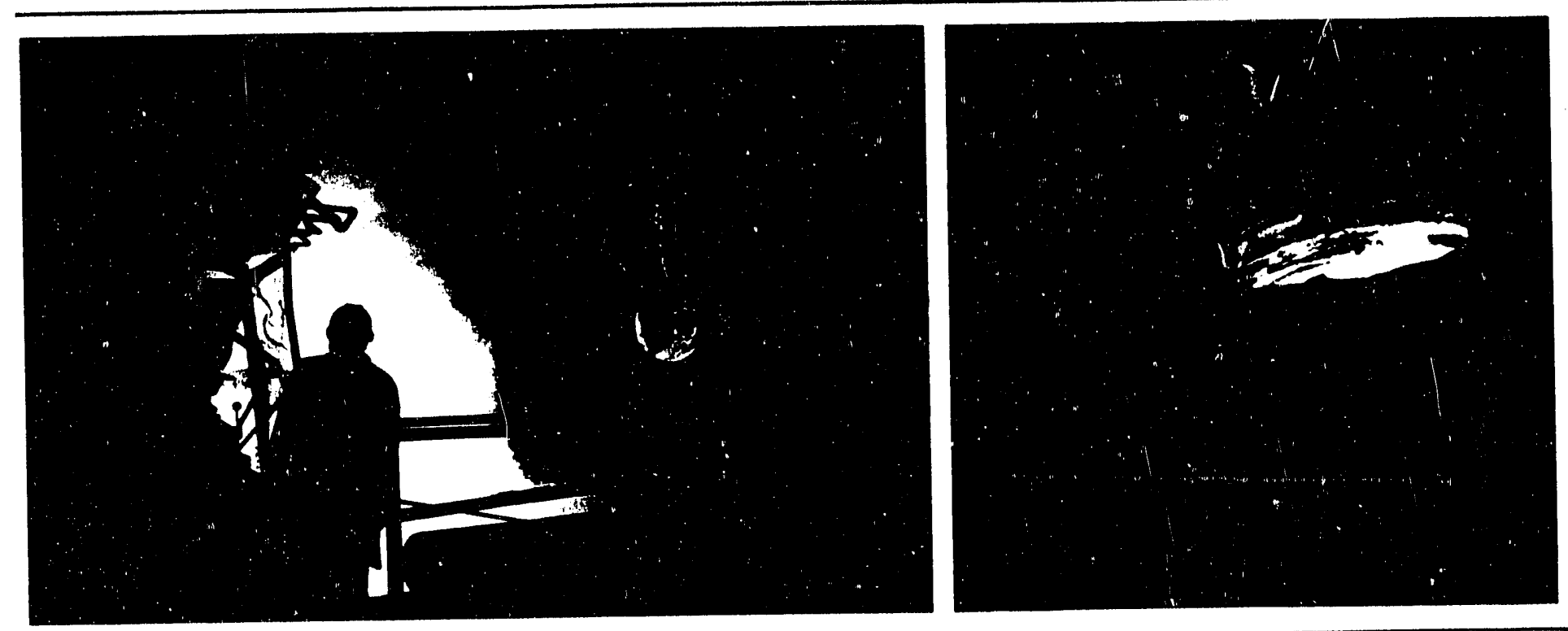

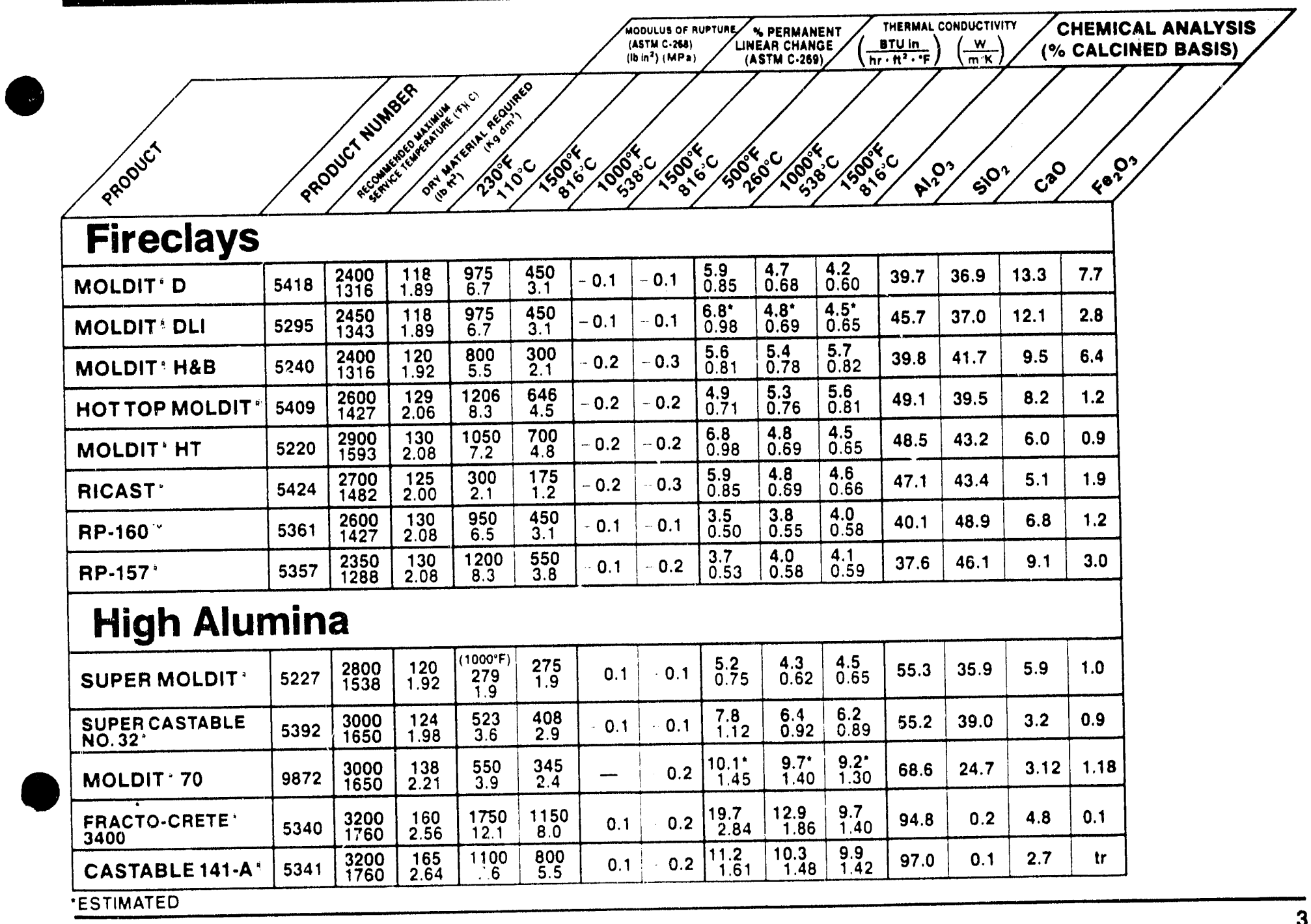




\section{Alumina-Silica Castables and Gunning Refractories... Technical Data}
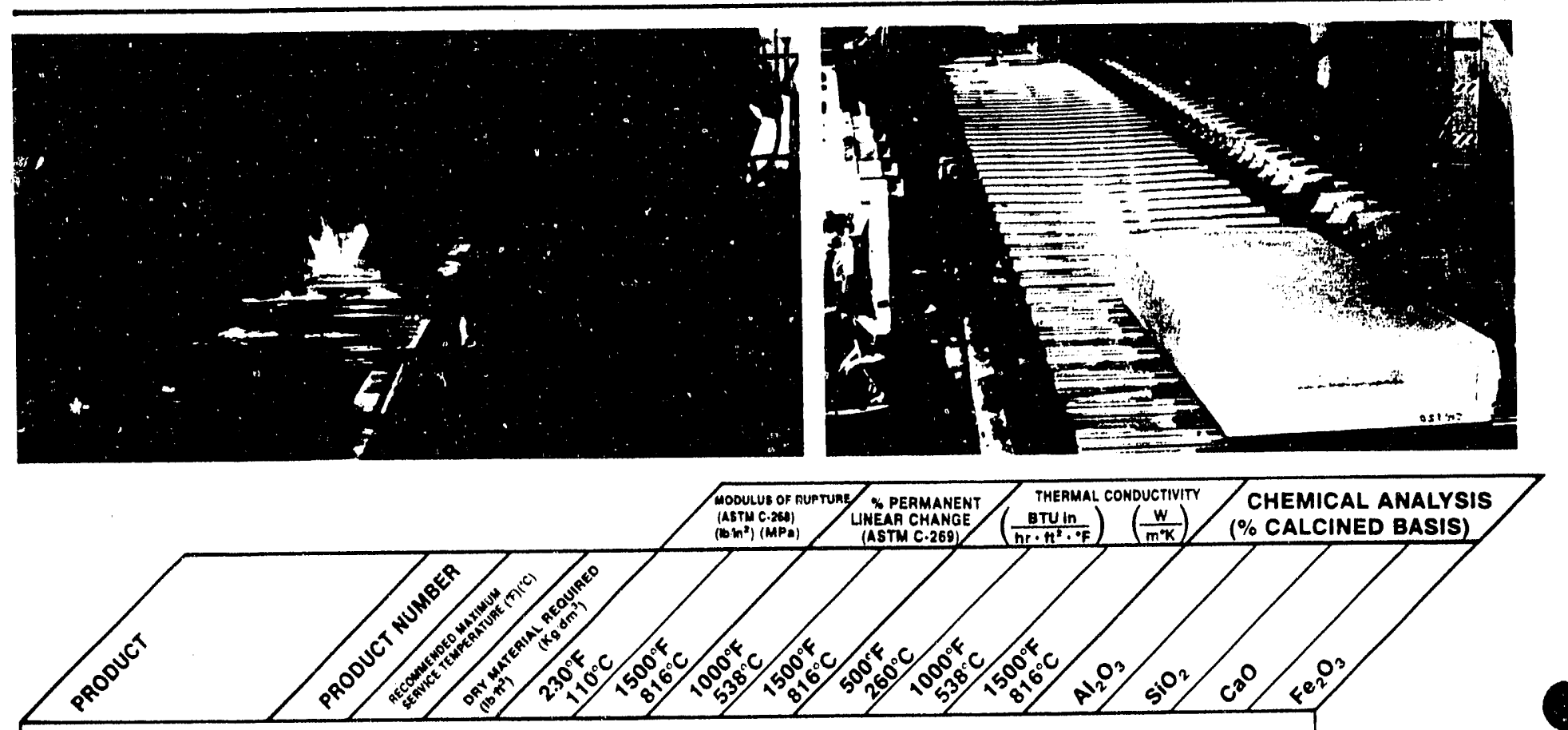

\section{Lightweight Insulations}

\begin{tabular}{|c|c|c|c|c|c|c|c|c|c|c|c|c|c|c|}
\hline $\begin{array}{l}\text { POUAABLE } \\
\text { INSULATION }\end{array}$ & 5253 & 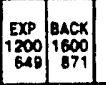 & $\begin{array}{c}35 \\
0.56\end{array}$ & $\begin{array}{l}70 \\
0.5\end{array}$ & {$\left[\begin{array}{c}\left(1000^{\circ} \mathrm{F}\right) \\
14 \\
0.1\end{array}\right.$} & -0.65 & -3.50 & $\begin{array}{l}0.8 \\
0.12\end{array}$ & $\begin{array}{l}1.0 \\
0.14\end{array}$ & - & 11.3 & 63.0 & 21.3 & 1.1 \\
\hline CER LITE ${ }^{\circledR} 18$ & 5489 & $\begin{array}{r}1800 \\
982 \\
\end{array}$ & $\begin{array}{c}20 \\
0.32\end{array}$ & 一 & - & 一 & - & $\begin{array}{l}0.8^{*} \\
0.12\end{array}$ & $\begin{array}{l}1.0^{*} \\
0.15\end{array}$ & $\begin{array}{l}1.2^{*} \\
0.18\end{array}$ & 25.5 & 37.3 & 13.5 & 7.7 \\
\hline LITE WATE 35 & 5212 & $\begin{array}{l}2000 \\
1093 \\
\end{array}$ & $\begin{array}{c}35 \\
0.56\end{array}$ & $\begin{array}{l}200 \\
1.4 \\
\end{array}$ & $\begin{array}{l}95 \\
0.7\end{array}$ & -0.1 & \begin{tabular}{|c|}
$\left(1800^{\circ} \mathrm{F}\right)$ \\
-0.1 \\
\end{tabular} & $\begin{array}{l}1.2 \\
0.17 \\
\end{array}$ & $\begin{array}{r}1.3 \\
0.19 \\
\end{array}$ & $\begin{array}{l}1.5 \\
0.22 \\
\end{array}$ & 31.8 & 19.9 & 27.7 & 12.9 \\
\hline LITE WATE 50 & 5323 & $\begin{array}{r}1800 \\
982 \\
\end{array}$ & $\begin{array}{l}42 \\
0.67\end{array}$ & $\begin{array}{l}130 \\
0.9 \\
\end{array}$ & $\begin{array}{l}70 \\
0.5 \\
\end{array}$ & -0.5 & -0.9 & $\begin{array}{l}1.3 \\
0.18 \\
\end{array}$ & $\begin{array}{l}1.2 \\
0.17\end{array}$ & $\begin{array}{l}2.0 \\
0.29 \\
\end{array}$ & 19.4 & 50.3 & 14.9 & 2.3 \\
\hline LITE WATE 58 & 5246 & 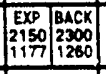 & $\begin{array}{l}58 \\
0.93 \\
\end{array}$ & $\begin{array}{r}200 \\
1.4 \\
\end{array}$ & $\begin{array}{l}100 \\
0.7 \\
\end{array}$ & -0.3 & -0.4 & $\begin{array}{l}2.3 \\
0.33 \\
\end{array}$ & $\begin{array}{l}2.0 \\
0.29 \\
\end{array}$ & $\begin{array}{l}1.9 \\
0.27 \\
\end{array}$ & 34.7 & 37.6 & 16.1 & 8.0 \\
\hline LITE WATE 70 & 5358 & $\begin{array}{l}2300 \\
1260 \\
\end{array}$ & $\begin{array}{c}78 \\
1.25 \\
\end{array}$ & $\begin{array}{l}450 \\
3.1 \\
\end{array}$ & $\begin{array}{l}350 \\
2.4 \\
\end{array}$ & -0.2 & -0.4 & $\begin{array}{l}3.0 \\
0.43 \\
\end{array}$ & $\begin{array}{l}2.6 \\
0.37\end{array}$ & $\begin{array}{l}2.3 \\
0.33 \\
\end{array}$ & 33.6 & 41.6 & 12.4 & 7.2 \\
\hline LITE WATE 80 & 5434 & $\begin{array}{r}2500 \\
1371 \\
\end{array}$ & $\begin{array}{c}80 \\
1.28 \\
\end{array}$ & $\begin{array}{l}290 \\
2.0\end{array}$ & $\begin{array}{l}145 \\
1.0 \\
\end{array}$ & -0.2 & -0.2 & $\begin{array}{l}3.6 \\
0.52\end{array}$ & $\begin{array}{l}2.9 \\
0.42 \\
\end{array}$ & 2.3 & 43.7 & 39.2 & 12.0 & 2.4 \\
\hline CER LITE $75 \mathrm{C}$ & 5292 & $\begin{array}{l}2750 \\
1510\end{array}$ & $\begin{array}{c}79 \\
1.26\end{array}$ & $\begin{array}{l}250 \\
1.7\end{array}$ & $\begin{array}{c}\left(100 \mathrm{U}^{\prime} \mathrm{F}\right) \\
270 \\
1.9\end{array}$ & -0.3 & $\left|\begin{array}{c}\left(2000^{\circ} \mathrm{F}\right) \\
-0.2\end{array}\right|$ & $\begin{array}{l}2.3 \\
0.33\end{array}$ & 2.2 & $\begin{array}{l}2.5 \\
0.36\end{array}$ & 53.9 & 40.7 & 2.9 & 0.9 \\
\hline LINS ${ }^{\circ} 5$ & 5216 & 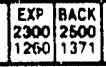 & $\begin{array}{c}50 \\
0.80\end{array}$ & $\begin{array}{l}250 \\
1.7\end{array}$ & - & -0.4 & -0.5 & $\begin{array}{l}1.7 \\
0.24\end{array}$ & $\begin{array}{l}1.6 \\
0.23 \\
\end{array}$ & $\begin{array}{l}1.5 \\
0.22 \\
\end{array}$ & 68.2 & 21.3 & 8.0 & 0.6 \\
\hline
\end{tabular}

\section{Abrasion Resistant}

\begin{tabular}{|c|c|c|c|c|c|c|c|c|c|c|c|c|c|c|}
\hline AR $-400^{\prime}$ & 5360 & $\begin{array}{l}2400 \\
1316\end{array}$ & $\begin{array}{l}165 \\
2.64 \\
\end{array}$ & $\begin{array}{l}1850 \\
12 . ?\end{array}$ & $\begin{array}{r}1900 \\
13.1 \\
\end{array}$ & -0.1 & 0.1 & $\begin{array}{l}7.1 \\
1.02 \\
\end{array}$ & $\begin{array}{l}7.3 .05 \\
1.05 \\
\end{array}$ & $\begin{array}{l}7.4 \\
1.06 \\
\end{array}$ & 62.0 & $\begin{array}{l}\mathrm{ZrO} \\
23.2\end{array}$ & 6.3 & 0.5 \\
\hline AR-153' & 5353 & $\begin{array}{l}2350 \\
1288\end{array}$ & $\begin{array}{l}141 \\
2.26\end{array}$ & $\begin{array}{l}1650 \\
11.4\end{array}$ & $\begin{array}{l}1660 \\
11.4\end{array}$ & -0.2 & - & $\begin{array}{l}8.11 \\
1.17\end{array}$ & $\begin{array}{l}7.4 \\
1.06\end{array}$ & $\begin{array}{l}6.6 \\
0.95\end{array}$ & 56.2 & 34.5 & 6.5 & 0.6 \\
\hline
\end{tabular}

\section{Aluminum}

\begin{tabular}{|c|c|c|c|c|c|c|c|c|c|c|c|c|c|c|}
\hline ALUGUARD " 75 & 9872 & $\begin{array}{l}2000 \\
1093\end{array}$ & $\begin{array}{c}75 \\
1.20\end{array}$ & $\begin{array}{l}417 \\
2.9\end{array}$ & $\begin{array}{l}206 \\
1.4\end{array}$ & - & 0.8 & $\begin{array}{l}3.0^{*} \\
0.43\end{array}$ & $\begin{array}{l}2.6 \\
0.37\end{array}$ & $\begin{array}{l}2.3^{*} \\
0.33\end{array}$ & 40.0 & 32.6 & 14.8 & 6.1 \\
\hline ALUGUARD *B & 9904 & $\begin{array}{l}2500 \\
1371\end{array}$ & $\begin{array}{l}166 \\
2.66\end{array}$ & - & $\begin{array}{l}770 \\
5.4\end{array}$ & - & 0.1 & $\begin{array}{c}\left(1832^{\circ} \mathrm{F}\right) \\
8.5^{\circ} \\
1.23\end{array}$ & $\begin{array}{l}\left(2192^{\circ} \mathrm{F}\right) \\
10.6^{\circ} \\
1.53\end{array}$ & - & 86.5 & 2.8 & 5.8 & 0.9 \\
\hline ALUGUARD * A & 9902 & 2500 & $\begin{array}{l}173 \\
2.79\end{array}$ & - & $\begin{array}{c}875 \\
6.1\end{array}$ & - & 0.1 & $\begin{array}{r}19.7^{\circ} \\
2.84\end{array}$ & $\begin{array}{r}12.9^{\circ} \\
1.86\end{array}$ & $\begin{array}{l}9.7^{\circ} \\
140\end{array}$ & 93.4 & 0.2 & 4.3 & 0.2 \\
\hline
\end{tabular}




\section{Alumina-Silica Castables and Gunning Refractories... Technical Data}

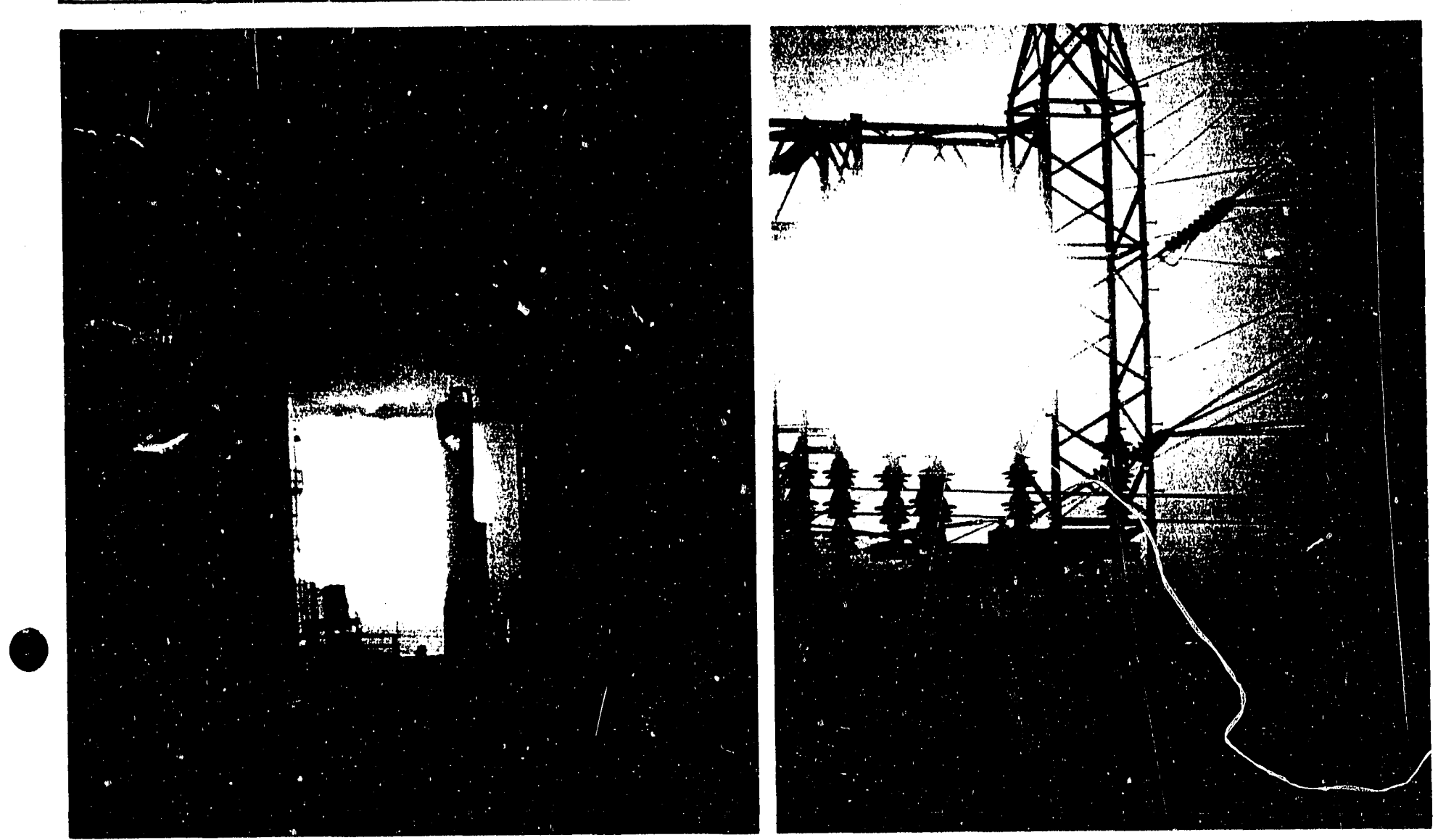

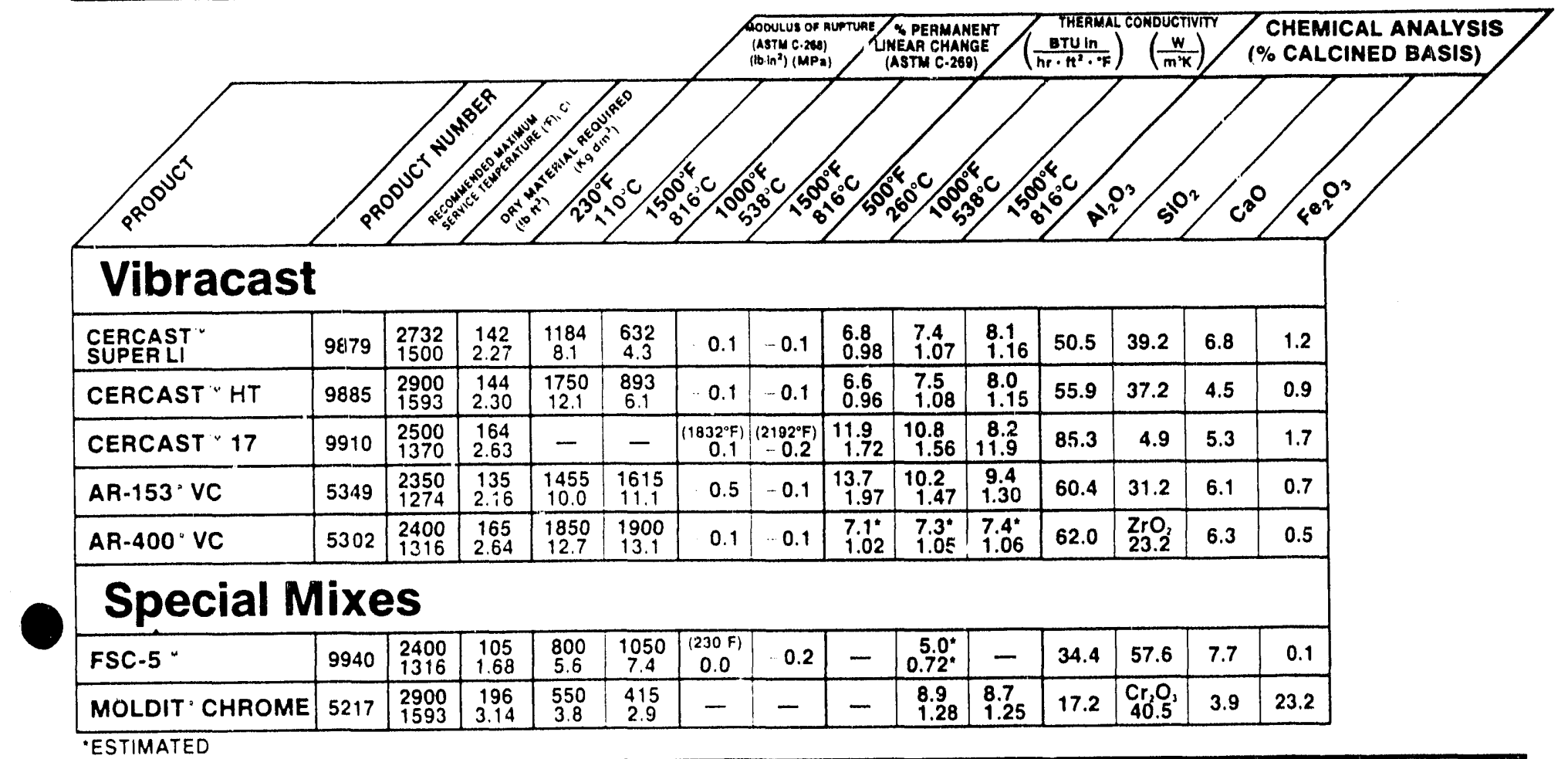




\section{Engineered Monolithic Lining \\ Construction... \\ Anchoring Systems}

\section{Engineored Monolithic Lining Systems}

C-E Refractories supplies engineered monolithic lining systems to meet specific energy-saving, abrasion resistance, strength, chemical compatibility and durability requirements.

These lining systems can be customized to satisfy individual customer needs. A full range of engineering, installation and technical support capabilities allows C.E Refractories to offer total monolithic linings systems. In addition to castables, these systems often involve other refractories, ceramic fiber insulations, metallic and/or ceramic anchoring, trained installation crews and detailed lightup schedules.

1) Roof lining with engineered ceramic anchoring (A-60 series).

2) Abrasion-resistant lining with engineered hexagonal steel mesh anchoring welded to shell.

3) Single component lining with engineered S-bar anchoring.

4) Single component lining with engineered " $\mathrm{V}$ " anchors welded to shell.

5) Two-component lining with engineered " $V$ " anchors and E-bolt attachments welded to shell.

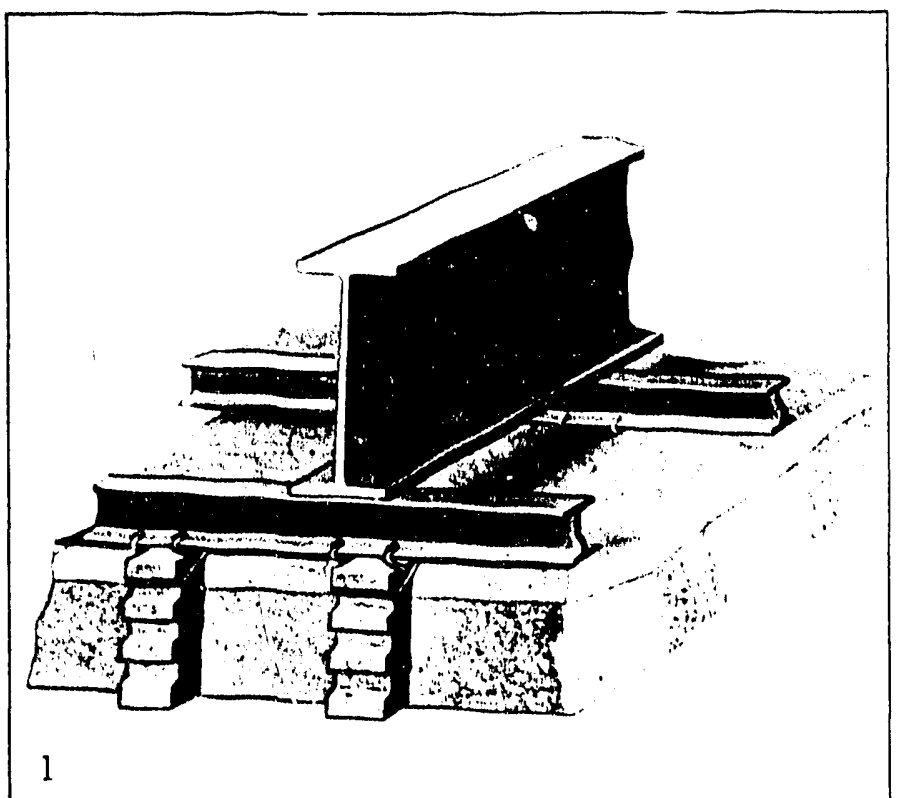

1 


\section{Engineered Monolithic Lining \\ Construction... Anchoring Systems}

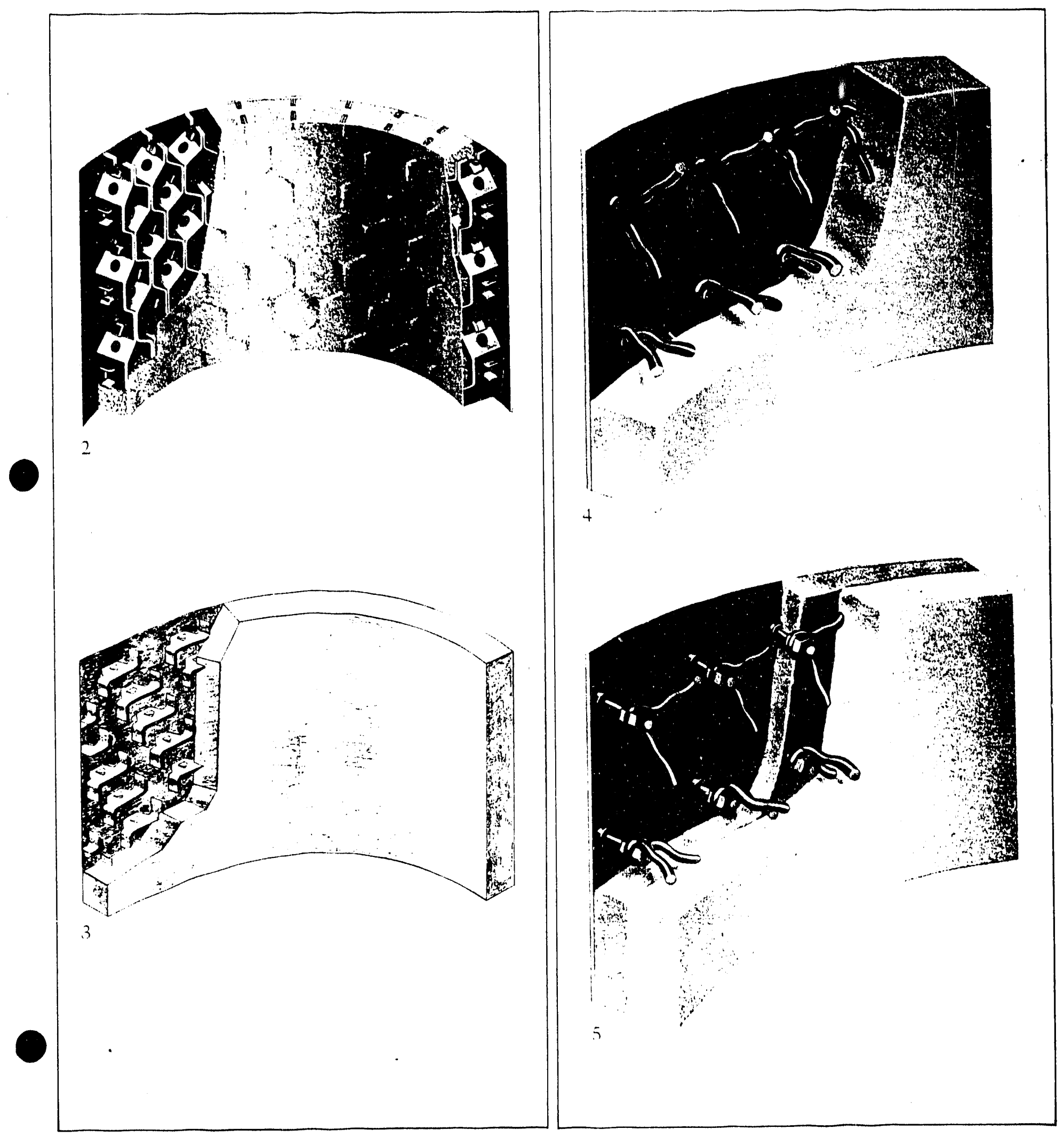


HARBISON - WALKER 


\section{REFRACTORY SYSTEMS \\ FOR}

\section{FLUIDIZED BED \\ COMBIISTION SYSTEMS}

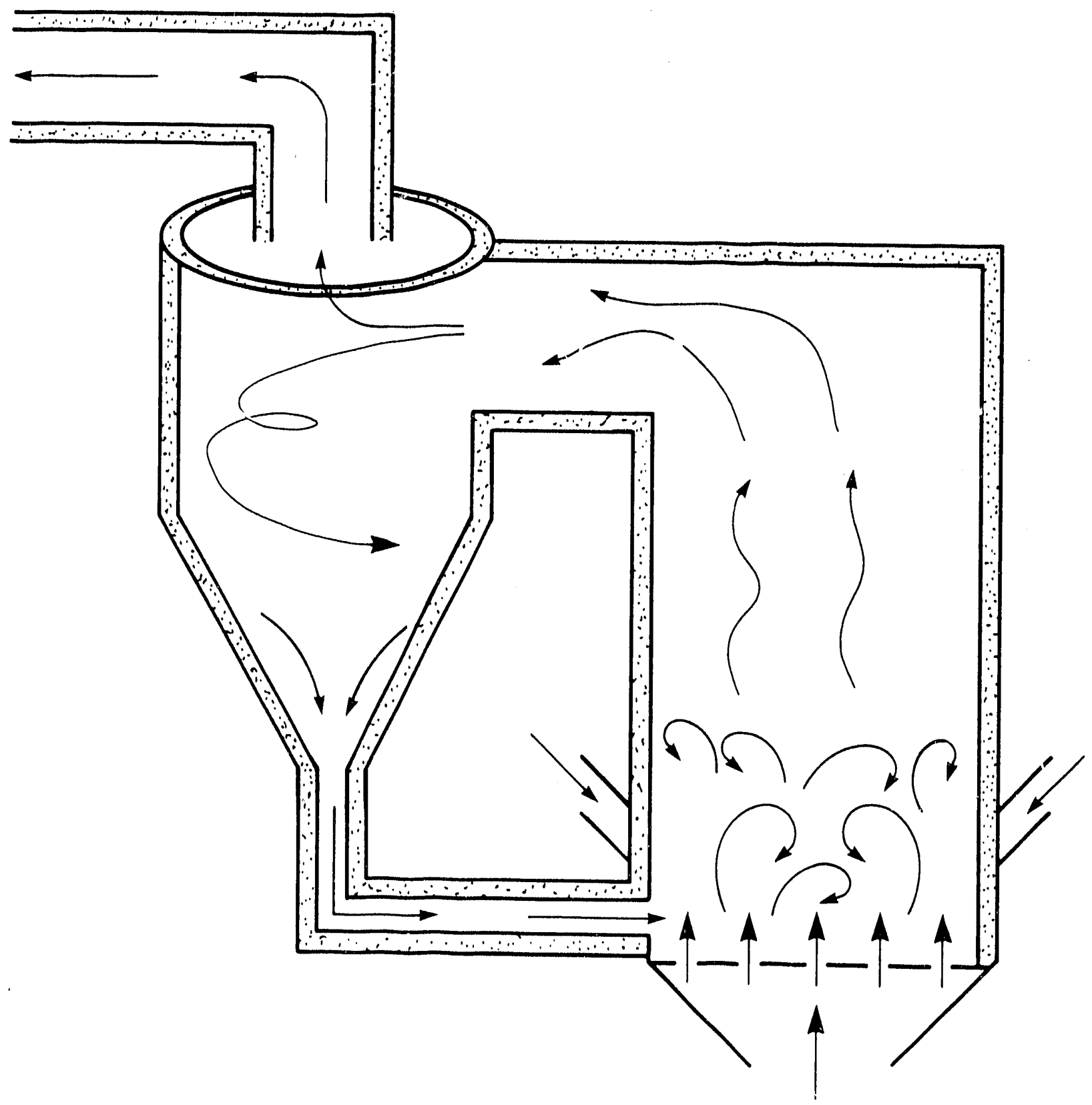


A) PRODUCT APPLICATIONS

- FOR SEVERE ABRASION CONDITIONS UP TO $2400^{\circ} \mathrm{F}$ -

Areas: Combustor and Cyclone (Hot Eace lining)

\section{Recommended Products}

\section{GUN MJXES}

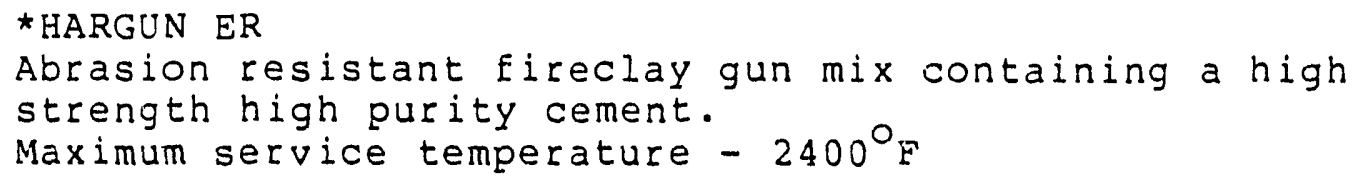

\section{CASTABLES}

* HARCAST ER

Aorasion resistant fireclay based castable containing a high strength, high purity cement.

Maximum service temperature - $2400^{\circ} \mathrm{F}$

\section{BRICK}

*H-W 61-65, KALA

508 Alumina Brick 
- FOR SEVERE ABRASION CONDITIONS UP TO $2800^{\circ} \mathrm{F}$ Areas: Combustor and cyclone (hot face lining)

Recommended Products

GUN MIXES

*HARGUN ES

Abrasion resistant fireclay based gun mix

Maximum service temperature - $2800^{\circ} \mathrm{F}$

VIBRATION CASTING MIXES

*HARVIBE

Abrasion resistant fireclay based mix designed for vibration casting.

Maximum service temperature $-2800^{\circ} \mathrm{F}$

\section{CASTABLES}

*HARCAST ES

Abrasion resistant fireclay based gastable

Maximuin service temperature - $2800^{\circ} \mathrm{F}$

$\underline{B R I C K}$

*CORAL BP

Burned, phosphate bonded $85 \%$ alumina brick

*KORUNDAL XD - mullite bonced, $90 z$ alumina brick 
- FOR HEAT CONTAINMENT WITH MINIMUM OR NO ABRASION, UP TO $2400^{\circ} \mathrm{F}$ -

Recommended Products

\section{GUN MIXES}

*TUFSHOT - fireclay based gun mix with a standard refractory cement.

Maximum service temperature - $2400^{\circ} \mathrm{F}$

\section{CASTABLES}

* ES CASTABLE - Eireclay based castable with a standard refractory cerient.

Maximum service temperature - $2400^{\circ} \mathrm{F}$

*ES CASTABLE C - coarse aggregate version

\section{BRICK}

* AIAMO S - superduty fireclay

* KALA - 508 a lumina

*UFALA - 60 s alumina 
- FOR :NSULATION -

Areas: Combustors and Cyclones (back-up lining)

\section{Recommended Products}

\section{GUN MIXES}

${ }^{*}$ LT. WT. GUN MIX $20-2000^{\circ} \mathrm{F}$ insulating gun mix

*LT. WT. GUN MIX $22-2200^{\circ}$ E insulating gun mix

${ }^{\star}$ LT. WT. GUN MIX $26-2600^{\circ} \mathrm{F}$ insulating gun mix

\section{CASTABLES}

*LT. WT. CASTABLE $16-1600^{\circ} \mathrm{F}$ insulating castable

*LT. WT. CASTABLE $20-2000^{\circ} \mathrm{F}$ insulating castable

* LT. WT. CASTABLE $22-2200^{\circ} \mathrm{F}$ insulating castable

*LT. WT. CASTABLE $26-2600^{\circ} \mathrm{F}$ insulating castable

${ }^{*}$ LT. WT. CASTABLE LI $-2200^{\circ} \mathrm{F}$ insulating castable

\section{$\underline{B R I C K}$}

${ }^{*} \mathrm{H}-\mathrm{W} 20 \mathrm{LI}-2000^{\circ} \mathrm{F}(\max$.

${ }^{\star} \mathrm{H}-\mathrm{W} 23$ LI $-2300^{\circ} \mathrm{F}$ (max.)

\section{MINERAL WOOL}

${ }^{*} \mathrm{H}-\mathrm{W}$ Block Insulation $-1900^{\circ} \mathrm{F}$ (max.)

NOTE: The possibility of "rat-holes" exists when applying block insulation to units with prescidre differentials. 
- FOR WATERWALL BOILER TUBE PROTECTION -

Recommended Products

GUN MIXES

*HARBIDE GUN MIX 80 ( $\mathrm{H}-\mathrm{W}$ 39-92)

808 silicon carbide gun/trowelling mix with a high strength, high purity cement.

\section{CASTABLES}

*HARBILE CASTABLE 80 (H-W 2-80)

808 silicon carbide castable with a high strength, high purity cement.

NOTE: It is suggested that the above silicon carbide products be applied over studded boiler tubes. 
- FOR HEAT CQNTAINMENT WITH MINIMUM OR NO ABRASION, UP TO $2600^{\circ}$ -

\section{Recommended products}

\section{GUN MIXES}

*TUESHOT LI - Eireclay based gun mix with an improved, low iron refractory cement.

Maximum service temperature - $2600^{\circ} \mathrm{F}$

\section{CASTABLES}

*ES CASTABle LI - Eireclay based castable with an improved, low iron refractory cement. Maximum service temperature - $2600^{\circ} \mathrm{F}$

*KILNCAST 26 - Extra coarse aggregate, fireclay based castable with an improved, low iron refractory cement. Maximum service temperature $-2600^{\circ} \mathrm{F}$

* Super castasle - fireclay based castable with an improved refractory cement.

\section{BRICK}

*ufala - 608 alumina

*aLUSa - 708 alumina 


\section{- MINIMIZE STEAM SPALLING AND INITIAL CRACKING - MAXIMIZE INITIA. $\mathrm{r}$ H-W's ADTECH' System: designed to maximiz}

THE ADTECH SYSTEM APPROACH

During heatup, the ADTE.CH additive's specia: , sperties cause it to shrink arid burn, thus producing minute, noncontinuous passageways in the refractory. This slight increase in permeability reduces the danger of steam spalling and allows faster heatuo rates by means of a fast, evenly distributed release of both the mechanically and chemically combined water.

\section{IMPROVED TECHNOLOGY/NEW CAPABILITIES}

H-W's advanced technology system utilizes extremely small additions that shrink and allow for release of steam and water from the lining at critical temperatures during the heatup. And because the additive in the ADTECH System is considerably smaller than in any other commercially available system, the passageways have little or no effect on properties such as strength and resistance to metal penetration. The $\mathrm{H} \cdot \mathrm{W}$ ADTECH System is the first technology-that produces steam passageways of the right size at the right time!

\section{Laboratory testing shows that the ADTECH System begins working as the steam ovolves from the lining and has \\ virtually disappeared long before other \\ commercially available additives show significant shrinkage.}

FOR ADDED SAFETY AND SECUIRITY AGAINST STEAM SPALLING, H-W'S ADTECH SYSTEM FACILITATES WATER RELEASE - WITH MINIMAL EFFECT ON PROPERTIES. COMPARE THE RESULTS.

\begin{tabular}{|c|c|c|c|c|c|c|c|}
\hline Product & $\begin{array}{l}\text { Density } \\
\text { After } \\
230^{\circ} \mathrm{F}\end{array}$ & \multicolumn{2}{|c|}{$\begin{array}{l}\text { Modulus of Rapture } \\
\text { (PSI) After } \\
230^{\circ} \mathrm{F} \quad{ }_{1500^{\circ} \mathrm{F}}\end{array}$} & \multicolumn{2}{|c|}{$\begin{array}{l}\text { Cold Crushing Strength } \\
\text { (PSI) After } \\
230^{\circ} \mathrm{F} \quad 1500^{\circ} \mathrm{F}\end{array}$} & \multicolumn{2}{|c|}{$\begin{array}{l}\text { Permanent Linear Change } \\
230^{\circ} \mathrm{F} \quad(\% / 0) \\
\quad 1500^{\circ} \mathrm{F}\end{array}$} \\
\hline Castolasieg & 20167 & 21502100 & 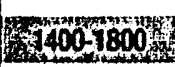 & $7000-12000$ & & Nogloblo & 4 \\
\hline $\begin{array}{l}\text { Castolast } \\
\text { Adtech }^{\top M}\end{array}$ & 165 & $1400-1800$ & $1300-1700$ & $7000-11000$ & $7000 \cdot 10000$ & Negligible & Negligible \\
\hline 7 Castiolos 60 & 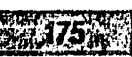 & $21200-40$ & Holonol & 3700012000 & 1000,12000 & Noollotbres & 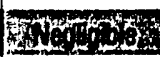 \\
\hline $\begin{array}{l}\text { Castolast }{ }^{\circ} \mathrm{GC} \\
\text { Adtech }\end{array}$ & 174 & $1200 \cdot 1700$ & $1200 \cdot 1700$ & $7000-12000$ & $7000-12000$ & Negligible & Negligible \\
\hline He Harcast ES & 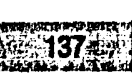 & 10001500 & $7000-1300$ & $6000-9000$ & $45000=7000$ & Propliolblog & 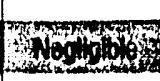 \\
\hline $\begin{array}{l}\text { Haicast } \\
\text { Adtech }^{\top M}\end{array}$ & 134 & $1000 \cdot 1300$ & $800-1100$ & $6000 \cdot 9000$ & $5000-7000$ & Negligible & Negligible \\
\hline $\begin{array}{l}\text { "Hwo } \\
\text { Lightwoight } \\
\text { Gun Mbx } 26\end{array}$ & 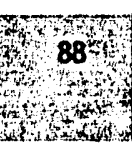 & 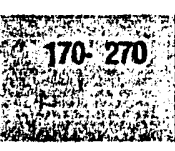 & 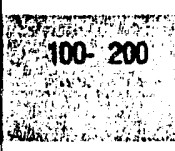 & 500800 & $\begin{array}{r}350-650 \\
6 \\
6\end{array}$ & 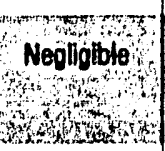 & 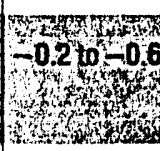 \\
\hline $\begin{array}{l}\text { "HW" } \\
\text { Lightweight } \\
\text { Gun Mix } 26 \\
\text { Adtech'M }\end{array}$ & 84 & 150. 250 & 75. 150 & 450.750 & 300. 600 & Negligible & $-0.210-0.6$ \\
\hline
\end{tabular}

values shown in table are based on actual manufacturing runs (not merely lab samples) of typical $H$-W refraclories All data is subject to reasonable deviation. and therefore should not be used tor specifization purposes H.W can supply Ouality Control data on every shipment to show representative properties
COMPETITIVE ADTECH ADDITIVE ADDITIVE
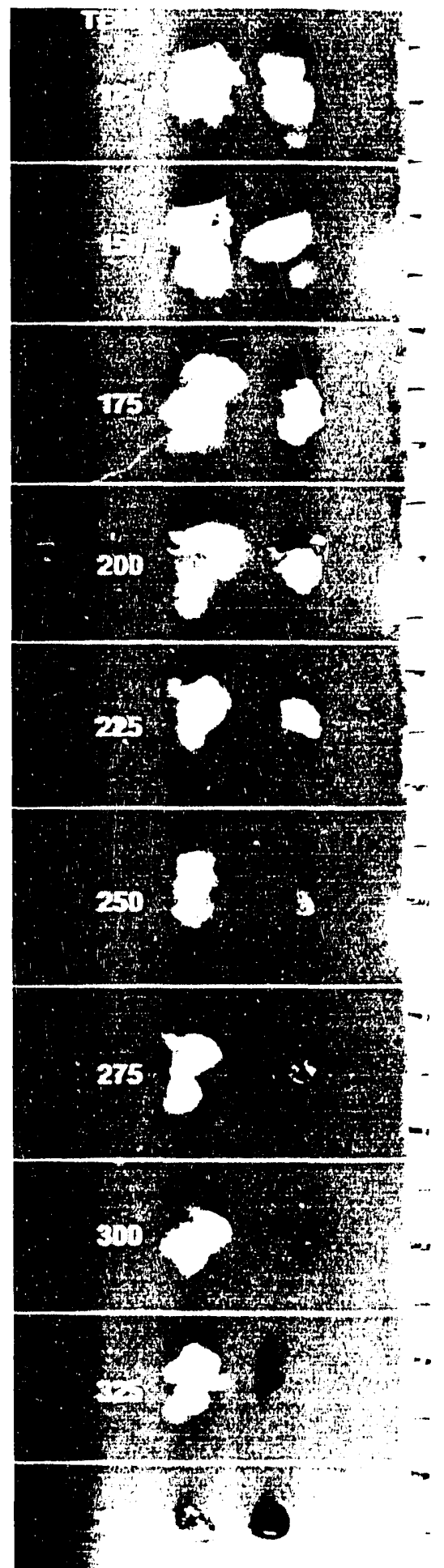

Cover photc courtes: of Westinghouse Electric Corporation Protectapt hi: Mark Portland

- Cast properties

- Due to minimal differences in measurable physical properties ano dotential improvements in spall and crack resistance. all CASTOLAST G and CG brand shipments will inc uoe the ADTECH'N system 


\section{ater release-for safer, accelerated heatups*}

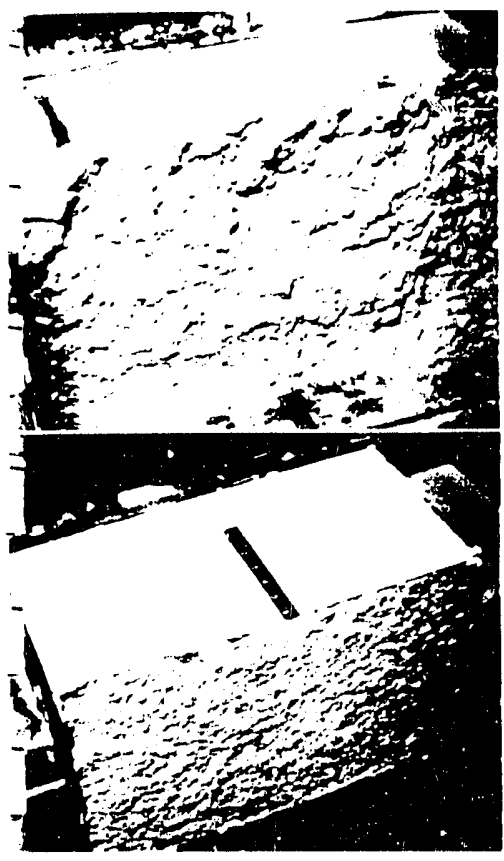

To approximate a furnace environment, the H.W steam spalling test incorporates a large $18^{\prime \prime} \times 12^{\prime \prime} \times 9^{\prime \prime}$ section of castable that is fired from one side. The material is air cured ior 24 hours and brought $102550^{\circ} \mathrm{F}$ in two hours.

The upper photo shows a dense, high purity, high alumina castable after 30 minutes in the sualling test. The $3^{\prime \prime}$ spalled section illustrates typical spalling experiunced in many applications. The lower photo shows the H.W ADTECH version of the same pioduct. Of the many other samples of

ADTECH castables and gun mixes also tested under the extreme conditions of the stean spalling test, none experienced spalling.

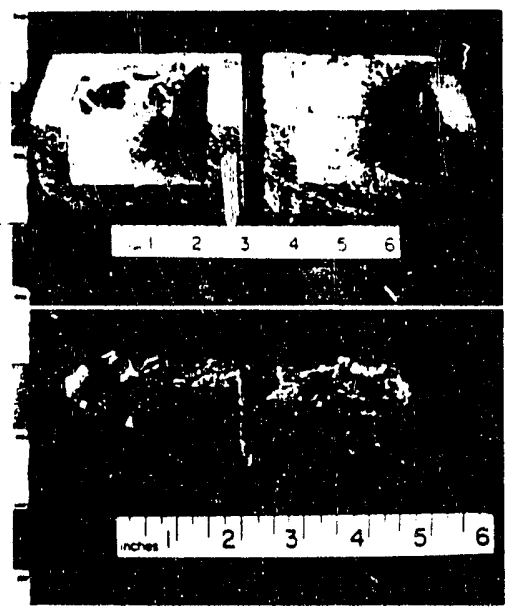

Extensive tests demonstrate a ADTECH refractory's resistance to metal penetration and cracking.

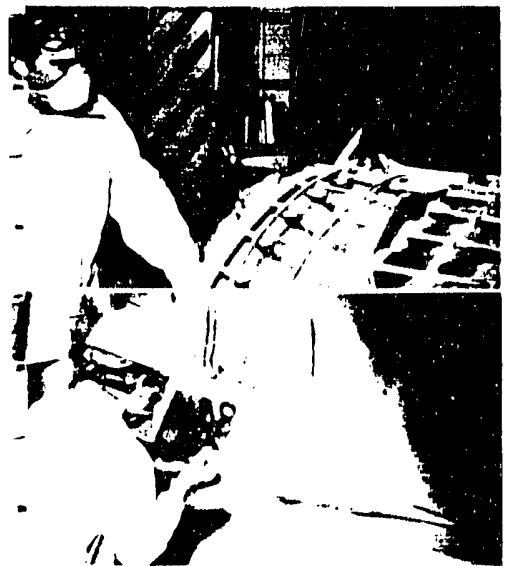

\section{HEATUP SCHEDULES}

When ADTECH castables or gunning mixes are used, initial heatup rates can be accelerated. However, as with /rick and plastic linings, the initial heatup rates of ADTECH linings must be examined individually. Parameters such as furnace size, lining thickness, material quality, expansion and temperature gradient vary with every furnace and affect the heatup rate. Based on laboratory heatup tests, microscopic analysis of the ADTECH material, and actual field installations, an accelerated heatup schedule can be formulated iriat shortens heatup t:me and maximizes energy savings, material properties, and safety. Please discuss your ispecific situation with the Harbison-. Walker Contractor-Installer or field representative.

\section{CRACK RESISTANCE} Minimized "Craze Cracking" Just as the ADTECH System can reduce steam spalling and maximize heat-up rates with passageways of the right size at the right time, the system also enables a lining to efficiently evolve water vapor during standard heat-ups, thereby reducing "craze cracks" that eventually propogate i, to spalls. With fewer shrinkage and "craze cracks", $A D T E C H$ linings have maximized service life in furnaces across the country.

\section{Maximized Metal Handling} In our tests and in the field, we have found minimal penetration into ADTECH metal contact refractories. In fact, because of the reduction of "craze cracks", some ADTECH metal contact refractories have shown less penetration and cracking than their standard counterparts.
ADTECH castables and gun mixes require no change in mixing with water, nor in application: The ADTECH System is available with most $\mathrm{H} \cdot \mathrm{W}$ castables and gun mixes. -Additives in the ADTECH System are considered non-toxic; however, the general application of any gunning material can produce nuisance dust and for that reason, respi. rators should be used

\section{APPLICATION}

To maximize heatups and maintain properties, please follow the mixing and curing instructions shown on the bag.

PROVEN IN A WIDE VARIETY OF APPLICATIONS. Harbison-Walker experience with the ADTECH Systein includes successful inst.allations in dozens of furnaces. Examples include rotary kilns, petrochemical vessels, coke oven repairs, AOD hoods, vertical channel induction furnaces, and other ferrous and nonferrous furnaces.

TO LEARN MORE ABOUT HOW YOU CAN GET THE SAFETY AND SECURITY .)F ADTECH REFRACTORIES, CALL YOUR NEAREST H-W OFFICE. 


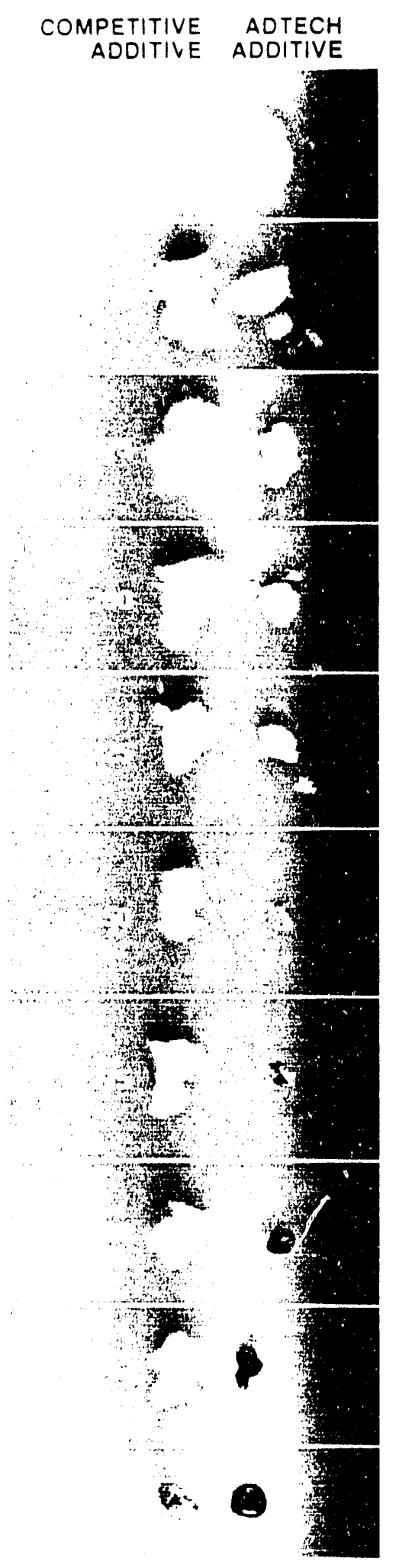

Figure 1. Laboratory testing shows that the ADTECH'M refractory system shrinks as steam evolves from the refractory lining, well below temperatures of shrinkage of sther additives.

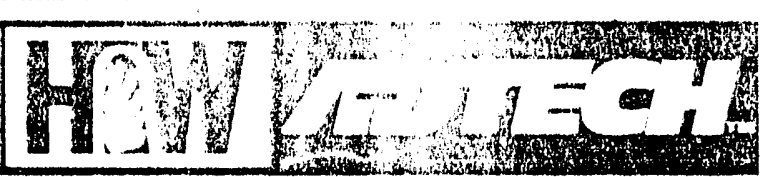

WATER RELEASE PASSAGEWAYS ARE THE KEY

\section{Safer Heat-ups}

During heat-up of castable and gun mix installations, the ADTECH ${ }^{\text {TM }}$ refractory system shrinks and burns producing minute, water release passageways in the refractory. These tiny pass geways greatly reduce the danger of steam spaltirig and allow safer maximum heat-ups by means of fast even release of both mechanical and chemically combined water. ADTECH ${ }^{T M}$ refractory system protection is esfecially important for cold weather installation.

\section{The Right Time}

To be effective, any steam release system must be required to shrink and burn at the right time, i.e., when the mechanical water begins to turn to steam.

Figure 1 shows the results of laboratory tests. They reveal that the ADTECH ${ }^{\text {TM }}$ refractory system permits shrinking and channel formation at $200^{\circ}$ F or less-well below the $212^{\circ} \mathrm{F}$ boiling point of water - while competitive additives do not begin shrinkage and channel formation until $300^{\circ} \mathrm{F}$ or more.

According to a recent technical paper, ${ }^{1}$ approximately one-half of the water loss in a castable or gunning mix occurs between 200 and $230^{\circ} \mathrm{F}$.

\section{The Right Size}

Channel formation in the refractory must also be of the right size, i.e., very fine, in order not to impair such properties as strength and ability to contain molten metal and slag.
The ADTECH ${ }^{\mathrm{TM}}$ refractory system forms smaller channels than are found in other commercially available castahle or gunning mix systems. Figure 2 shows scarining electron microprobe innages from laboratory studies which revealed the channels in ADTECH ${ }^{T M}$

refractory specimens to be at least $20 \%$ sinaller than the competition. Permeability and resistance to metal penetration tests are run on samples of ADTECH ${ }^{\top M}$ refractory products from commercial production to check on proper physicá, characteristics.

\section{Laboratory Designed}

With the speed and safety of furnace turnarounds becoming increasingly more important, Harbison-Walker turned to their research and developmen: facility to be sure that the apprcach they brought to the market place would provide the customer the best protection while hisving the leust possible effect on other properties of their products. The ADTECH ${ }^{\mathrm{TM}}$ refractory system described here is the result of that intensive testing program.

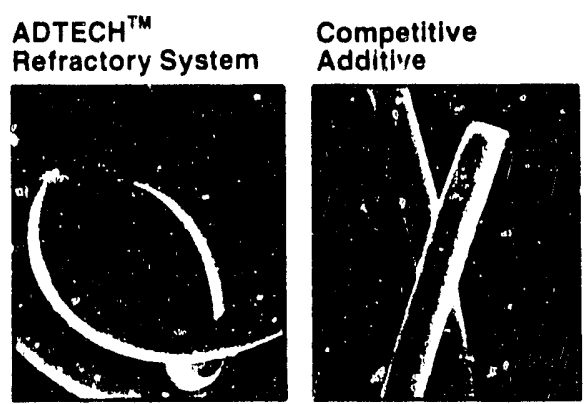

Figure 2. Enlarged 300 times, the AUTECH ${ }^{\text {TM }}$ channel forming elements are 10 to $20 \%$ smaller than those developed in other products. Very small passages are necessary to maintain the properties of the monollth. 


\section{3etter Installations}

On initial heat-up of any dense castable or gunning mix installation must relieve the vapor pressure created as the water is driven off. Conventional compositions will spall away and/or create a network of cracks and crazes that weaken the structure and shorten service life. Often this damage is not visible on the surface of the lining.

With the ADTECH ${ }^{T M}$ refractory system, cracking or crazing is reduced to a minimum and, therefore, the strength and integrity of the lining is increased. In other words, a better installation can result.

Faster initial heat-up rates demand the extra measure of protection afforded by the ADTECH ${ }^{T M}$ refractory system.

\section{Laboratory Testing}

To provide decumentation for the above proposition, we performed explosion tests on large $300 \mathrm{lb}$. slocks of CASTOLAST ${ }^{\circ} \mathrm{G}$ with and without the ADTECH ${ }^{\top M}$ refractory system. The test block is air dried only for 24 hours and then slaced in the test furnace. A raging burner neats the block from one side, reaching $1900^{\circ} \mathrm{F}$ in 30 minutes and $2500^{\circ} \mathrm{F}$ in one hour. Table 1 shows the results obtained on specimens without an additive and with increasing amounts according to the patented ADTECH ${ }^{\top M}$ refractory system.

\section{Two primary points emerge from this study:}

1. The hot face of the samples visibly and dramatically improved in soundness as the ADTECH ${ }^{T M}$ refractory system was increased to the curreit standard level (si mple C).

2. However, even at a depth of 7 to 9 in. from the hot face, the strength of sample $\mathrm{C}$ was more than $25 \%$ greater than sample $A$ without any treatment. This is strong evidence that damage in the form of micro cracking can penetrate deep into a castable lining and that the

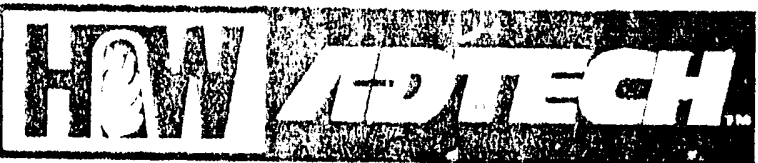

BETTER INSTALLA IIONONS

\begin{tabular}{|l|c|c|c|}
\hline $\begin{array}{l}\text { ADTECH } \\
\text { Refractory System }\end{array}$ & A & B & C \\
\hline $\begin{array}{l}\text { Zonal Crushing } \\
\text { Strength }\end{array}$ & $0 \%$ & $X \%$ & $\begin{array}{l}\text { Current ADTECH } \\
\text { Refractory System }\end{array}$ \\
\hline $\begin{array}{l}\text { O-2 in. from } \\
\text { Hot Face }\end{array}$ & $\begin{array}{l}\text { Steam } \\
\text { Spalled }\end{array}$ & $\begin{array}{l}\text { Extensive cracking } \\
\text {-no measurable } \\
\text { strength }\end{array}$ & $8200 \mathrm{psi}$ \\
\hline $\begin{array}{l}\text { 3-5 in. from } \\
\text { Hot Face }\end{array}$ & $9970 \mathrm{psi}$ & $9960 \mathrm{psi}$ & $11,560 \mathrm{psi}$ \\
\hline $\begin{array}{l}7.9 \text { in. from } \\
\text { Hot Face }\end{array}$ & $9030 \mathrm{psi}$ & $10,700 \mathrm{psi}$ & $11,440 \mathrm{psi}$ \\
\hline
\end{tabular}

Table 1: Experimental Castolast" G Samples

A

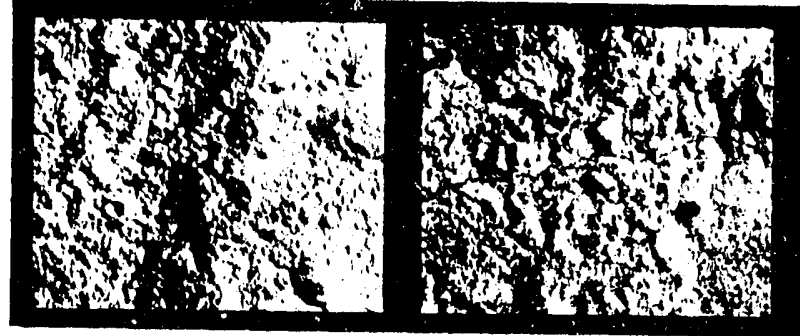

Figure 1: Photographs of samples from Table 1.

ADTECH ${ }^{\mathrm{TM}}$ refractory system provides better linings as well as safer heat-ups.

The technology incorporated into sample $C$ is now incorporated into all ADTECH ${ }^{\text {TM }}$ brand products.

\section{Value Added Feature}

The ADTECH ${ }^{\text {TM }}$ refractory system is being furnished with all shipments of refractory brands such as CASTOLAST $\mathrm{G}$ and $\mathrm{GC}$ CASTOLAST Gun Mix and DESCON ${ }^{\top M} A 98$ at no extra charge. Other products are available with the ADTECH ${ }^{\mathrm{TM}}$ refractory system feature at a slight premium.

\section{Heat-up Schedules}

When ADTECH ${ }^{\text {TM }}$ castables or gunning mixes are used, initial heat-up rates can be accelerated. However, as with brick or plastic linings, the initial heat-up rates of ADTECH ${ }^{T M}$ installations must be examined on an individual basis. Furnace size, lining thickness, material quality, expansion and temperature gradients vary with every installation and will affect the heat-up rates. Please discuss specific heat-up schedules with a Harbison-Walker field representative or your contractor installer. 
The initial laboratory studies of the ADTECH ${ }^{\text {TM }}$ refractory system were primarily directed toward safer heatups and sound, strong installations.

Additional technical work by Virginia Polytechnical Institute', HarbisonWalker and an independent laboratory has provided further evidence as to why the ADTECH ${ }^{\mathrm{TM}}$ refractory system works. It is also shown that ADTECH ${ }^{\top M}$ castable and gunning mix installations will be safer to dry out and heat up in cold weather, and that they have good metal contact properties and are more resistant to thermal shock.

The various technical studies and the field benefits they have yielded are tabulated in Table 1.

\section{Virginia Polytechnical Institute Studies}

A unique probe, developed by VPI and reported to the ACS in 1982, is capable of measuring pressures developed within castables at various depths during the heat-up process. This probe was used to study internal pressures developed with $90 \%$ alumina castables both with and without ADTECH ${ }^{\mathrm{TM}}$ treatment, at two different depths in the casting: At the same depths the pressures developed within the ADTECH ${ }^{\text {TM }}$ refractory system is 15 to $20 \%$ lower than in conventional castables - further evidence that the ADTECH ${ }^{T M}$ refractory system can better facilitate steam release and provide safer heat-ups. (Shown in Table 2.)

\section{Metal Contact Studies}

The ability to use the ADTECH ${ }^{\text {TM }}$ refractory system products in metal contact applications is indicated by the condition of laboratory saniples shown in Figure 1. These cup samples held 7075 aluminum alloy-one which has great penetrating powerat $815^{\circ} \mathrm{C}$ for 5 days. There was no difference in aluminum penetration between the fiber free product and the ADTECH ${ }^{T M}$ product. The

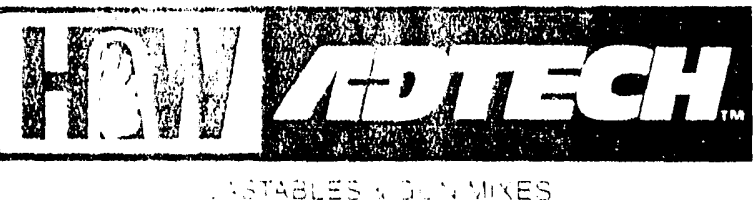

\section{ADDITIONAL BENEFITS THROUGH TECHNOLOGY}

Table 1

\begin{tabular}{|c|c|}
\hline Techriology & Field Benefits \\
\hline $\begin{array}{l}\text { - Fiber shrinkage studies } \\
\text { (Bulletin \#1) } \\
\text { - SEM studies (Bulletin \#1) } \\
\text { - VPI internal pressure studies }\end{array}$ & Safer, faster heat-ups \\
\hline $\begin{array}{l}\text { - Explosion testing (Bulletin \#2) } \\
\text { - Zonal crushing strength tests } \\
\text { (Bulletin \#2) }\end{array}$ & Stronger installation \\
\hline - Motal contact tests & Good metal contact properties \\
\hline - Thermal cycling tests & Better resistance to thermal shock \\
\hline - Curing temperature studies & $\begin{array}{l}\text { Additional measure of protection } \\
\text { in cold weather installations }\end{array}$ \\
\hline - Crack resistance studies & $\begin{array}{l}\text { Reduction of dry out cracks, } \\
\text { improves service life }\end{array}$ \\
\hline
\end{tabular}

Table 2

\begin{tabular}{|c|c|c|}
\hline \multicolumn{3}{|c|}{$\begin{array}{l}\text { Maximum Internal Pressure of } 90 \% \text { Alumina Castable Heated on One Face } \\
\text { at } 275^{\circ} \mathrm{C} / \mathrm{hr} \text {. }\end{array}$} \\
\hline $\begin{array}{l}\text { Depth From Hot Face } \\
\text { CM }\end{array}$ & Standard Castable & APa \\
\hline $\begin{array}{l}2.5 \\
7.6\end{array}$ & $\begin{array}{l}723 \\
723\end{array}$ & $\begin{array}{l}572 \\
614\end{array}$ \\
\hline
\end{tabular}

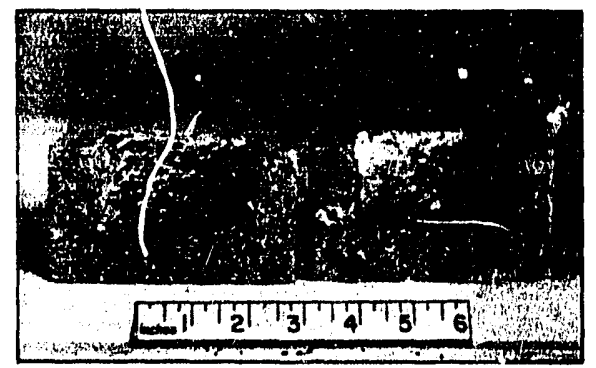

Figure 1: Extensive tests demonstrate Adtechrm Refractory's resistance to metal penetration.

residual aluminum was easily peeled off the ADTECH ${ }^{\text {rM }}$ sample but stuck to the standard sample. This non-wetting phe romenon has been seen in a variety of ADTECH ${ }^{\top M}$ castables tested in the laboratory and is the subject of continuing investigation.

Laboratory test results are now supported by two years of excellent field experience in metal contact applications.

\section{Thermal Cycling Studies}

The laboratory prism spalling test cycles samples between a hot furnace and a water quench repeatedly until they fail by cracking. In such procedures ADTECH ${ }^{\mathrm{TM}}$ refractory samples endured between 30 to $60 \%$ more cycles than did the standard samples.

Resistance to thermal cycling is not unexpected for products that contain the ADTECH ${ }^{\top M}$ refractory system. Crack propagation theory teaches that cracking is inhibited in ceramic bodies by discontinuities in the matrix. In the ADTECH ${ }^{\mathrm{TM}}$ refractory system, the discontinuities occur as regularly placed micro channels rather than macro pores or voids that are present in other spall resistant ceramics.

Such evidence indicates that ADTECH ${ }^{\text {TM }}$ castables and gun mixes should be quite resistant to - 
thermal shock under field conditions. Thermal shock occurs with removable roofs, intermittently heated chambers, ladles and runners where metal filling or flow is frequently interrupted.

\section{Independen+ Laboratory Studies \\ Crack Resistance- The Basic Benefit}

Extensive published work by others ${ }^{2}$ has shown that a major contributing factor to steam spalling in castables is the gel-like cement phases formed when castables are cured at temperatures below $70^{\circ} \mathrm{F}$. The gel structure can act as an impenetrable barrier to the escape of steam during the drying and firing cycles.

The ADTECH ${ }^{\text {TM }}$ refracto 'y system successfully reduces the steam spalling tendency by increasiing the micro permeability of castables and gun mixes during the drying anc' curing cycles, as shown in Figure 2. It is never recommended that castables or gun mixes be cured at temperatures as low as $50^{\circ} \mathrm{F}$ because strength will be impaired and steam spalling tendencies increased, whether or not they ha've the ADTECH ${ }^{\top M}$ refractory system.
However, it is apparent that the ADTECH ${ }^{T M}$ refractory system provides additional protection against steam spalling during heat up even under these adverse conditons.

On initial heat-up, any dense castable or gunning mix installation must relieve the vapor pressure created as the water is driven off. Often a network of cracks and crazes will be created which may not be visible to the naked eye but which can be penetrated by the furnace charge and then be more rapidly eroded. Studies of both laboratory samples and field samples reveal that with the ADTECH ${ }^{T M}$ refractory system such cracking and crazing is minimized and furnace wear by penetration and erosion thereby minimized.
90\% ALUMINA HIGH PURITY CEMENT CASTABLE EXPLOSION TEMP. ${ }^{\circ} \mathrm{F}$ v CURING TEMP. ${ }^{\circ} \mathrm{F}$

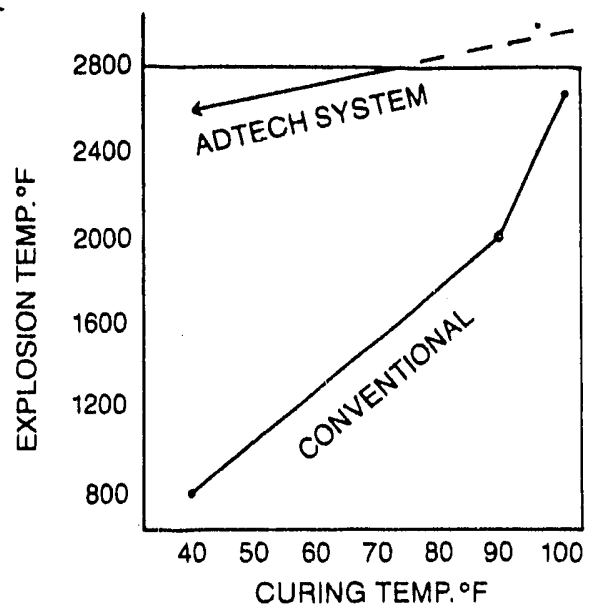

Figure 2: The steam spalling temperature is the highest furnace temperature that an undried 2.5 in. cube can withstand when placed in a hot furnace. The spalling temperature changes relative to the 24-hour curing conditions.2

Additives in the ADTECH ${ }^{T M}$ refractory system are considered non-toxic; however, the general apulication of any gunning material can produce nuisance dust, and for that reason, respirators should be used.

NOTE OF CAUTION: The danger of steam spalling exists with all castables and gun mixes, with or without non-metallic additions. However, when used properly, the ADTECHTM retractory system offers greater improvement over conventional gunning mixes and castables.

TO LEARN MORE ABOUT THE SAFETY AND ENERGY SAVING FEATURES OF ADTECHTM REFRACTORIES, CALL YOUR NEAREST HARBISON-WALKER OFFICE.

${ }^{1}$ Hipps, D. L. and Brown, J. J. "Measurement of Internal Pressure in High Alumina Castable During Curing" presented to annual meeling of ACS, 1982

2Gitzen, W. H. and Hart, L. D. "Explosive Spalling of Retractory Castables Bonded with Calcium Aluminate Cement",

Aluminum Company of Americe.

\section{HARBISON-WALKER NORTH AMERICAN OPERATIONS MARKETING OFFICES}

Birmingham, AL
(205) $785-3132$

Burlington, Ontario

(416) 335-1777

Charlotte, NC

(704) 334-2826

Chicago, IL

(312) 474-4774

(219) 838-0550

Cincinnati, $\mathrm{OH}$

(513) $891-1200$
Cleveland, $\mathrm{OH}$

(216) 243-2700

Detroit, $\mathrm{MI}$

(313) 273-3100

Houston, TX

(713) $750-3769$

Montreal, Quebec

(514) 9:31-4u54

Philadislphia, PA

(215) 647-6533
Pittsburgh, PA

(412) 562-6200 (General Offices)

(412) 343-0050 (Industrial)

(412) 562-6585 (Iron \& Steel)

St. Louis, MO

(314) 569-1774

Seattle, WA

(206) $455-2555$

Harbison-Walker Refractories International

Export Sales Office. One Gateway Center, Pittsburgh, PA 1522.2 (USA)

Telex: 86-6184/Cable: Harwalk/Phone: (412) 562-6567

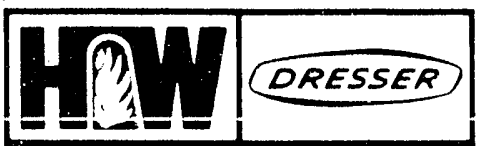


FIGURE A

TYPICAL WORK OF FRACTURE Standard Refractory Castable vs

Fiber Reinforced Refractory Castable

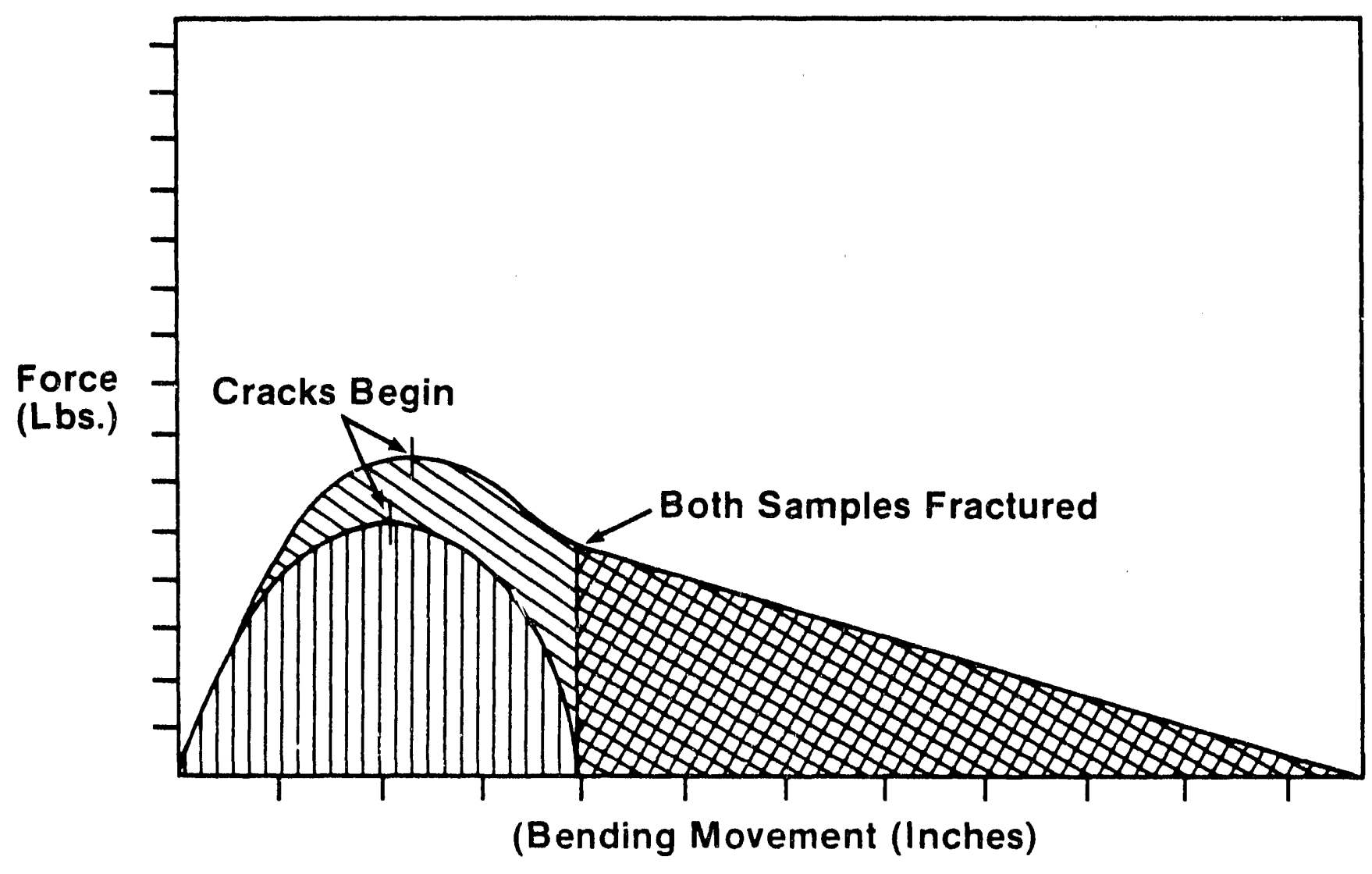

Standard $\llbracket[\|ा\|$ Work or Energy Required to Crack, Fracture and Sample Separate (Work of Fracture)

Fiber Additional Work Necessary to Crack and Fracture Fiber Sample

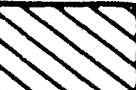
Reinforced Sample (Extra Crack Resistance)

Fiber Sample Additional Work Necessary to Separate Fiber Reinforced Sample (Extra Holding Power) 
- LIMITED DATA -

EARGUN ER

Technical Data:

Physical Properties: (Typical)

Maximum Service Temperature

Gunning Mix Required (Net)

Bulk Density

After Drying at $230^{\circ} \mathrm{F}\left(110^{\circ} \mathrm{C}\right)$

Modulus of Rupture

After Drying at $230^{\circ} \mathrm{F}\left(110^{\circ} \mathrm{C}\right)$

After Heating at $1500^{\circ} \mathrm{F}\left(815^{\circ} \mathrm{C}\right)$

Cold Crushing Strength

After Drying at $230^{\circ} \mathrm{F}\left(110^{\circ} \mathrm{C}\right)$

After Heating at $1500^{\circ} \mathrm{F}\left(815^{\circ} \mathrm{C}\right)$

Permanent Linear Change, o

After Drying at $230^{\circ} \mathrm{F}\left(110^{\circ} \mathrm{C}\right)$

After Heating at $1500^{\circ} \mathrm{F}\left(815^{\circ} \mathrm{C}\right)$

Chernical Analysis:

(Approximate)

(Calcined Basis)

silica

$$
\left(\mathrm{SiO}_{2}\right)
$$

31.08

Alumina

$\left(\mathrm{Al}_{2} \mathrm{O}_{3}\right)$

60.3

Titania

$\left(\mathrm{TiO}_{2}\right)$

1.6

Iron Oxide

$\left(\mathrm{Fe}_{2} \mathrm{O}_{3}\right)$

0.7

Lime

(CaO)

6.1

Magnesia

Alkalies
(MgO)

$\left(\mathrm{Na}_{2} \mathrm{O}+\mathrm{K}_{2} \mathrm{O}+\mathrm{Li}_{2} \mathrm{O}\right)$
Negligible $-0.08$
SI Units

$1,316^{\circ} \mathrm{C}$

$\mathrm{kg} / \mathrm{m}^{3}$

2,130

2,260

$\underline{k P a}$

8,300 to 12,400

6,900 to 11,000

All data based on gunned specimens. ASTM procedures, where applicable, used for determination of data.

All data subject to reasonable deviation, and therefore, should not be used for specification purposes.

$$
\text { HD- } 6
$$


Drosser Industrios Inc.

One Gateway Center, Pittsburgh, PA 15222

\section{- LIMITED DATA -}

\section{HARCAST ER}

Technical Data:

\section{Physical Properties: (Typical)}

Maximum Service Temperature

Dry Weight Required for Casting
English Units

$2,4000^{F}$

$1 b / E t^{3}$

135
SI Units

$1,316^{\circ} \mathrm{C}$

$\mathrm{kg} / \mathrm{m}^{3}$

2,160

Approximate Amount of Water Required
Per 100 Lbs.
Per $45.36 \mathrm{~kg}$.

Bulk Density

After Drying at $230^{\circ} \mathrm{F}\left(110^{\circ} \mathrm{C}\right)$

Modulus of Rupture

After Drying at $230^{\circ} \mathrm{F}\left(110^{\circ} \mathrm{C}\right)$

After Heating at $1500^{\circ} \mathrm{F}\left(815^{\circ} \mathrm{C}\right)$

After Heating at $2700^{\circ} \mathrm{F}\left(1480^{\circ} \mathrm{C}\right)$

Cold Crushing Strength

After Drying at $230^{\circ} \mathrm{F}\left(110^{\circ} \mathrm{C}\right)$

After yeating at $1500^{\circ} \mathrm{F}\left(815^{\circ} \mathrm{C}\right)$

After Heating at $2700^{\circ} \mathrm{F}\left(1480^{\circ} \mathrm{C}\right)$

Permanent Linear Change, of

After Drying at $230^{\circ} \mathrm{F}\left(110^{\circ} \mathrm{C}\right)$

After Heating at $1500^{\circ} \mathrm{F}\left(815^{\circ} \mathrm{g}\right)$

After Heating at $2700^{\circ} \mathrm{F}\left(1480^{\circ} \mathrm{C}\right)$

4.72 to

5.68 Liter

$1 b / e t^{3}$

1.42

$1 \mathrm{~b} / \mathrm{in}^{2}$

1,850

2,310

3,710 .

8,740

9,190

9,400 $\underline{\mathrm{kg} / \mathrm{m}^{3}}$

2,270

$\mathrm{kPa}$

12,800

15,900

25,600

60,300

63,400

64,800

Chemical Analysis:

(Approximate)

(Calcined Basis)

\section{silica}

Alumina

Titania.

Iron Oxide

Lime

Magnesia

Alkalies

$\begin{array}{lc}\left(\mathrm{SiO}_{2}\right) & 31.0 \% \\ \left(\mathrm{Al}_{3} \mathrm{O}_{3}\right) & 60.3 \\ \left(\mathrm{TiO}_{2}\right) & 1.6 \\ \left(\mathrm{Fe}_{2} \mathrm{O}_{3}\right) & 0.7 \\ \left(\mathrm{CaO}^{2}\right) & 6.1 \\ (\mathrm{MgO}) & 0.1 \\ \left(\mathrm{Na}_{2} \mathrm{O}+\mathrm{K}_{2} \mathrm{O}+\mathrm{Li}_{2} \mathrm{O}\right) & 0.2\end{array}$

Negligible

0.0

$-4.4$ 
BARGUN ES

Techrical Data:

Physical Properties: (Typical)

Gunning Mix Required

Bulk Density

After Drying at $230^{\circ} \mathrm{F}\left(110^{\circ} \mathrm{C}\right)$

Modulus of Rupture

After Drying at $230^{\circ} \mathrm{F}\left(110^{\circ} \mathrm{C}\right)$

After Heating at $1500 \% \mathrm{~F}\left(816^{\circ} \mathrm{C}\right)$

After Heating at $2700^{\circ} \mathrm{F}\left(1482^{\circ} \mathrm{C}\right.$
English Units

$\frac{1 b / f t^{3}}{130}$

135

$1 \mathrm{~b} / \mathrm{in}^{2}$

900 to 1,400

700 to 1.200

2,000 to 2,500
SI Units

$$
\frac{\mathrm{kg} / \mathrm{m}^{3}}{2,080}
$$

2,160

$\underline{\mathrm{kPa}}$

Cold Crushing Strength

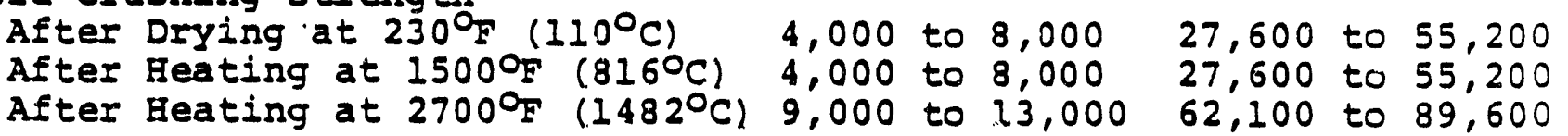

Permanent Iinear Change, 8

$\begin{array}{rr}\text { After Heating at } 1500^{\circ} \mathrm{F}\left(816^{\circ} \mathrm{C}\right) & 0.0 \text { to }-0.3 \\ \text { After Heating at } 27000^{\circ}\left(1482^{\circ} \mathrm{C}\right) & -0.3 \text { to }-0.8\end{array}$

Chemical Analysis:

(Approximate)

(Calcined Basis)

Silica

$\left(\mathrm{SiO}_{2}\right)$

35.38

Alumina

$\left(\mathrm{Al}_{2} \mathrm{O}_{3}\right)$

55.7

Titania

$\left(\mathrm{TiO}_{2}\right)$

1. 6

Iron Oxide

$\left(\mathrm{Fe}_{2} \mathrm{O}_{3}\right)$

0.8

Eime

( $\mathrm{CaO}$

5.5

Magnesia

(MgO)

0.3

Alkalies

$\left(\mathrm{Na}_{2} \mathrm{O}+\mathrm{K}_{2} \mathrm{O}+\mathrm{Li} \mathrm{i}_{2} \mathrm{O}\right)$

0.8

All data based on gunned specimens. ASTM procedures, where applicable, used for determination of data.

All data subject to reasonable deviation and therefore should not be used for specification purposes.

GI-6 (Rev.) $=$ technical data $=$ (continued) 
Drossur Industrios Inc.

One Gatoway Conter, Pittsburgh, PA 15222

Technical Data:

- LIMITED DATA -

AARVIBE

(Eorme IIY H-W 18-84)

Physical properties: (Typlcal)

Dry Weight Required for Casting
English Units

$$
1 b / E t^{3}
$$

140
SI Units

$\mathrm{kg} / \mathrm{m}^{3}$

2,240

Approximate Amount of Water Required
Per 100 Lbs.
PeI $45.36 \mathrm{Rg}$.
1 to 1 1/8 U.S. Gallons 3.79 to 4.26 Liters

Bulk Density

After Drying at $230^{\circ} \mathrm{F}\left(110^{\circ} \mathrm{C}\right)$

$1 b / E t^{3}$

$\mathrm{kg} / \mathrm{m}^{3}$

148

2,370

Modulus of Rupture

ifter Drying at $230^{\circ} \mathrm{F}\left(110^{\circ} \mathrm{C}\right)$

After leating at $150^{\circ}\left(815^{\circ} \mathrm{c}\right)$

After Heating at $2700^{\circ} \mathrm{b}\left(1480^{\circ} \mathrm{C}\right)$

$1 b / i n^{2}$

$\underline{k P a}$

1,500

10,300

1,700

11,700

1,900

13,100

Cold Crushing strength

After Drying at $230^{\circ} \mathrm{F}\left(110^{\circ} \mathrm{C}\right)$

8,600

59,300

16,600

114,500

After leating at $2700^{\circ} \mathrm{g}\left(1480^{\circ} \mathrm{C}\right)$

12,000

82,700

Permanent Linear Change, o

After Drying at $230^{\circ} \mathrm{F}\left(110^{\circ} \mathrm{C}\right)$

After Heating at $1500^{\circ} \mathrm{F}\left(815^{\circ} \mathrm{g}\right)$

After Heating at $2700^{\circ} \mathrm{F}\left(1480^{\circ} \mathrm{C}\right)$

Negligible

$-0.2$

$+1.3$

Chemical Analysis: (Approximate)

\section{(calcined Basis)}

Silica

Alumina

Titania

Iron 0:ide

Lime

Magnesia

Alkalies
$\left(\mathrm{SiO}_{2}\right)$

$\left(\mathrm{Al}_{2} \mathrm{O}_{3}\right)$

$\left(\mathrm{TiO}_{2}\right)$

$\left(\mathrm{Fe}_{2} \mathrm{O}_{3}\right)$

( $\mathrm{CaO})$

( $\mathrm{MgO})$

$\left(\mathrm{Na} a_{2} \mathrm{O}+\mathrm{K}_{2} \mathrm{O}+\mathrm{Li} \mathrm{i}_{2} \mathrm{O}\right)$
32.48

59.7

1.4

0.7

5.0

0.2

0.6 


\section{HARCAST ES}

Technical Data:

Physical Properties: (Typical)

Maximum Service Temperature

Dry Weight Required for Casting
English Units

$$
2,800^{\circ} \mathrm{F}
$$$$
\frac{1 b / f t^{3}}{132}
$$

SI Units

$1,5400^{\circ} \mathrm{C}$

$\frac{\mathrm{kg} / \mathrm{m}^{3}}{2,115}$

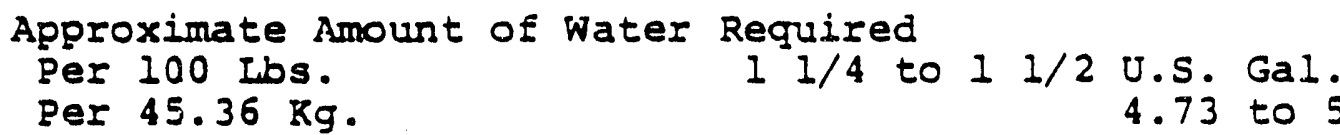

\section{per $45.36 \mathrm{~kg}$.}

Bulk Density

After Drying at $230^{\circ} \mathrm{F}\left(110^{\circ} \mathrm{C}\right)$

Modulus of Rupture

After Drying at $230^{\circ} \mathrm{F}\left(110^{\circ} \mathrm{C}\right)$

After Heating at $1000^{\circ} \mathrm{F}\left(540^{\circ} \mathrm{C}\right)$

After Heating at $15000 \mathrm{~F}$ (8150 C)

After Heating at $2700^{\circ} \mathrm{F}\left(1480^{\circ} \mathrm{C}\right)$

Cold Crushing Strength $\frac{1 b / f t^{3}}{138}$

$1 \mathrm{~b} / \mathrm{in}^{2}$

1,000 to 1,500

900 to 1,300

900 to 1,300

$i, 200$ to 1,900 to 5.68 Iiters

$\frac{\mathrm{kg} / \mathrm{m}^{3}}{2,210}$

\section{$\mathrm{kPa}$}

6,900 to 10,30

6,200 to 9,000

6,200 to 9,000

8,300 to 13,10
Atter Jrying at $230^{\circ} \mathrm{F}\left(110^{\circ} \mathrm{C}\right)$

After Heating at $1000^{\circ} \mathrm{F}\left(540^{\circ} \mathrm{C}\right)$

After Heating at $1500^{\circ} \mathrm{F}\left(815^{\circ} \mathrm{C}\right)$

After Heating at $27000 \mathrm{~F}$ (1.4800 C)

Permanent Linear Change, o

After Drying at $230^{\circ} \mathrm{F}\left(110^{\circ} \mathrm{C}\right)$

After Heating at $1000^{\circ} \mathrm{F}\left(540^{\circ} \mathrm{C}\right)$

After Heating at $1500^{\circ} \mathrm{F}\left(815^{\circ} \mathrm{C}\right)$

- After Heating at $2700^{\circ} \mathrm{F}\left(1480^{\circ} \mathrm{C}\right)$

6,000 to 9,000

5,000 to 7,000

5,000 to 7,000

8,000 to 10,000
41,400 to 62,10

34,500 to 48,30

34,500 to 48,30

55,200 to $69,0 J$

Chemical Analysis:

(Approximate)

(Calcinec Basis)

\author{
Silica \\ Alumina \\ Titania \\ Iron Oxide \\ Lime \\ Magnesia \\ Alkalies
}

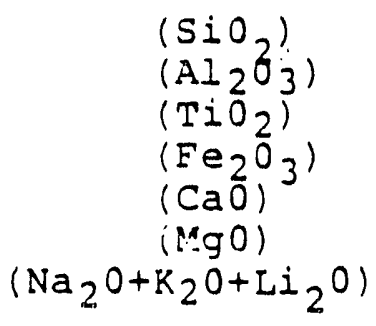

$\left(\mathrm{Al}_{2} \mathrm{O}_{3}\right)$

$\left(\mathrm{TiO}_{2}\right)$

$\left(\mathrm{Fe}_{2} \mathrm{O}_{3}\right)$

( $\because 90)$

$\left(\mathrm{Na}_{2} \mathrm{O}+\mathrm{K}_{2} \mathrm{O}+\mathrm{Li}_{2} \mathrm{O}\right)$
Negligible

Negligible

Negligible

-1.5 to 0.0

$\mathrm{HJ}-\mathrm{I}$ (Rev.)

35.63

55.6

1.6

0.8

5.4

0.3

0.7 
RALA

(Formerly H-W 1-77)

Classification: Hagh Alumina Brick

Physical Data: (Typical)

Bulk Density

Apparent Porosity, \&

Cold Crushing strength, psi

Modulus of Rupture, psi
English Units

$$
1 \mathrm{~b} / \mathrm{ft} \mathrm{t}^{3}
$$

$$
150 \text { to } 155
$$$$
13.0 \text { to } 15.0
$$

$$
\underline{1 b / i \Omega^{2}}
$$

6,000 to 9,000

1,500 to 2,500
SI Units

$$
\mathrm{kg} / \mathrm{m}^{3} \text {. }
$$

$$
2,400 \text { to } 2,480
$$$$
13.0 \text { to } 15.0
$$

$\underline{k P a}$

41,400 to 62,100

10,300 to 17,200

Reheat Test

Permanent Iinear Change,

After Heating at $2910^{\circ} \mathrm{E}\left(1600^{\circ} \mathrm{C}\right)$

0.0 to +0.5

Load Test, 25 psi (172 kPa)

\& Linear Subsidence

After Heating to $2640^{\circ} \mathrm{F}\left(1450^{\circ} \mathrm{C}\right.$ )

0.0 to 0.5

Chemical Aralysis:

(Approximate)

Silica

Alumina

Titania

Iron Oxide

ine

Magnesia

Alkalies
$\left(\mathrm{SiO}_{2}\right)$

$\left(\mathrm{Al}_{2} \mathrm{O}_{3}\right)$

$\left(\mathrm{TiO}_{2}\right)$

$\left(\mathrm{Fe}_{2} \mathrm{O}_{3}\right)$

( $\mathrm{CaO})$

( $\mathrm{MgO})$

$\left(\mathrm{Na}_{2} \mathrm{O}+\mathrm{K}_{2} \mathrm{O}+\mathrm{Li} \mathrm{i}_{2} \mathrm{O}\right)$
$46.4 \%$

49.6

2.2

1.4

0.1

0.1

0.2

The above data are typical of properties of commercial g" straight brick. The data are subject to reasonable variations and therefore, should not be used in specification purposes. of data.

ASTM Test Methods, where applicable, used for determination

$H D-11$ 


\section{UFALA}

Classification: High-Alumina Brick

Physical Data: (Typical)

Bulk Density

Apparent Porosity, o

Cold Crushing strength

Modulus of Rupture

Reheat Test

Permanert Iinear Change ( 8 )

After Heating at $2910^{\circ} \mathrm{F}\left(1600^{\circ} \mathrm{C}\right)$

Load Test, 25 psi (172 kPa)

\& Iinear Subsidence

After Heating at $26400 \mathrm{~F}\left(1450^{\circ} \mathrm{C}\right)$

Parel Spalling Test

\& Loss

Preheat - 30000F (16500 C)

$\frac{\text { English Units }}{\underline{1 b / \mathrm{et}}} \quad \frac{\text { SI Units }}{\mathrm{kg} / \mathrm{m}^{3}}$

156 to 1602,500 to 2,565

12.0 to $16.0 \quad 12.0$ to $16: 0$

$1 \mathrm{~b} / \mathrm{in} \mathrm{n}^{2} \quad \mathrm{kPa}$

7,000 to $10,00048,300$ to 69,00

2,500 to $3,300 \quad 17,300$ to 22,80

Chemical Analysis:

(Approxirate)

Silica

Alumina

Titania

Iron Oxide

Iime

Magnesia

Alkalies
$\left(\mathrm{SiO}_{2}\right)$

$\left(\mathrm{Al}_{2} \mathrm{O}_{3}\right)$

$\left(\mathrm{TiO}_{2}\right)$

$\left(\mathrm{Fe}_{2} \mathrm{O}_{3}\right)$

$(\mathrm{CaO})$

( $\mathrm{MgO})$

$\left(\mathrm{Na}_{2} \mathrm{O}+\mathrm{K}_{2} \mathrm{O}+\mathrm{Ii}_{2} \mathrm{O}\right)$
0.0 to -0.5

0.1 to 0.5

0 to 3

The above data are typical of the properties of commerical $9 "$ straight brick. The data are subject to reasonable variations and therefore should not be used for specification purposes. of data.

ASTM Test Methods, where applicable, used for determination

Protected by U.S. Patent No. 3,241,989.

See reverse side for cutting recommendations.

HA -1 


\section{CORAI BP}

Classification: High Alumina Brick - Phosphate Bonded (Burned)

Physical Data: (Typical)

Bulk Density

Apparent Porosity, o

cold Crushing strength

Modulus of Rupture

Reheat Test

Permanent Iinear Change, of

After Heating at $2910^{\circ} \mathrm{F}\left(1600^{\circ} \mathrm{C}\right)$

Load Test, 25 psi ( $172 \mathrm{kPa}$ )

\& Linear Subsidence

After Heating at $2640^{\circ} \mathrm{F}\left(1450^{\circ} \mathrm{C}\right)$

Chemical Analysis:

(Approximate)

silica

Alumina

Titania

Iron Oxide

Phosphorous Pentoxide

$$
\left(\mathrm{SiO}_{2}\right)
$$

9.68

$$
\left(\mathrm{Al}_{2} \mathrm{O}_{3}\right)
$$$$
\left(\mathrm{TiO}_{2}\right)
$$$$
\left(\mathrm{Fe}_{2} \mathrm{O}_{3}\right)
$$

$\left(\mathrm{P}_{2} \mathrm{O}_{5}\right)$
English Units

$1 b / f t^{3}$

175 to 180

14.0 to 18.0

$1 \mathrm{~b} / \mathrm{in}^{2}$

10,000 to 16,000

2,700 to 3,500

$$
+0.5 \text { to }-0.6
$$

2,800 to 2,880

14.0 to 18.0

$\underline{\mathrm{kPa}}$

69,000 to $110,30 \mathrm{C}$

18,600 to 24,100

The above data are typical of the properties of commercial 9" straight brick. The data are subject to reasonable variations and therefore should not be used for specification purposes. of data.

ASTM Test Methods, where applicable, used for determination

Patent Applied For.

See reverse side for cutting recommendations.

$H A-10$ 


\section{RORUNDAL XD}

Classification: High Alumina Brick

Physical Properties: (Typical)

Buluk Density

Apparent Porosity, \&

Cold Crushing strength

Modulus of Rupture

Reheat Test

Permanent Linear Change, of

After Beating at $3140^{\circ} \mathrm{F}\left(1725^{\circ} \mathrm{C}\right)$

Load Test, 25 psi ( $172 \mathrm{kPa}$ )

After Heating at $3300^{\circ} \mathrm{F}\left(1815^{\circ} \mathrm{C}\right)$

Panel Spalling Test

of Loss

Preheat - $3000^{\circ} \mathrm{F}\left(1650^{\circ} \mathrm{C}\right)$

Chemical Analysis:

(Approximate)
English Units

$$
1 b / E t^{3}
$$

$$
181 \text { to } 185
$$

14.0 to 18.0

$$
1 \mathrm{~b} / \mathrm{in}^{2}
$$

9,000 to 14,000

62,100 to $96,60 \mathrm{C}$

2,000 to 3,000

13,800 to $20,70 \mathrm{C}$

SI Units

$\mathrm{kg} / \mathrm{m}^{3}$

2,900 to 2,960

14.0 to 18.0

$\mathrm{KPa}$

$$
\begin{gathered}
+0.6 \text { to }+1.0 \\
0.3 \text { to } 1.4
\end{gathered}
$$

0 to 0

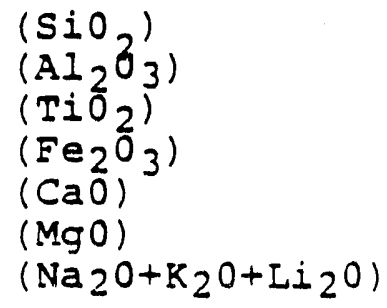

\begin{abstract}
Silica
Alumina

Titania

Iron Oxide

Lime

Magnesia

Alkalies
\end{abstract}

$\begin{array}{lc}\left(\mathrm{SiO}_{2}\right) & 11.0 \frac{3}{3} \\ \left(\mathrm{Al}_{2} \mathrm{O}_{3}\right) & 88.1 \\ \left(\mathrm{TiO}_{2}\right) & 0.3 \\ \left(\mathrm{Fe}_{2} \mathrm{O}_{3}\right) & 0.2 \\ (\mathrm{CaO}) & 0.1 \\ \left(\mathrm{MgO}^{2}\right) & 0.04 \\ \left(\mathrm{Na}_{2} \mathrm{O}+\mathrm{K}_{2} \mathrm{O}+\mathrm{Ii}_{2} \mathrm{O}\right) & 0.2\end{array}$

The above data are typical of the properties of commercial $9 "$ straight brick. The data are subject to reasonable variations and therefore should not be used for specification purposes. of data.

ASTM Test Methods, where applicable, used for determination

See reverse side for cutting recommendations.

Protected by U.S. Patent \#3,067,050

$\mathrm{HA}-10$ 
Dresser Industriv inc.

One Gateway Censer, Pitssburgh, PA 15222

EARBIDE GUNNING MIX 80

Technical Data:

Physical Properties: (Iypical)

Gunning Mix Required (Net)

Bulk Density

After Drying at $230^{\circ} \mathrm{F}\left(110^{\circ} \mathrm{C}\right)$

Modulus of Rupture

After Drying at $230^{\circ} \mathrm{F} / 110^{\circ} \mathrm{Cb}$

After beating at $1500^{\circ} \mathrm{F}\left(815^{\circ} \mathrm{g}\right)$

After beating at $2730^{\circ} \mathrm{F}\left(1500^{\circ} \mathrm{C}\right)$

Cold $C$, thing strength

After Lrying at $230^{\circ} \mathrm{F} /\left(110^{\circ} \mathrm{C}\right.$ b

After leating at $1500^{\circ}\left(815^{\circ} \mathrm{g}\right)$

After leating at $2730^{\circ} \mathrm{F}\left(1500^{\circ} \mathrm{C}\right)$

Permanent Linear Change

After Drying at $230^{\circ} \mathrm{F} /\left(110^{\circ} \mathrm{C}\right.$

After reating at $1500^{\circ}\left(815^{\circ} \mathrm{g}\right)$

After leating at $2730^{\circ} \mathrm{F}\left(1500^{\circ} \mathrm{C}\right)$

Chemical Analysis:

(Approximate)

silicon Carbide

silica

Alumina

Titania

Iron Oxide

Lime

Magnesia

Alkalies

$\mathrm{HF}-3$
English Units

$1 b / E t^{3}$

140

$1 b / E t^{3}$

145

$1 b /$ in $^{2}$

800 to 1,100

800 to 1,100

2,200 to 2,800

3,000 to 6,000

2,000 to 5,000

3,000 to 6,000

20,700 to 41,400

13,800 to 34,500

20,700 to 41,400
SI Units

$\mathrm{Kg} / \mathrm{m}^{3}$

2,240

$\mathrm{Rg} / \mathrm{m}^{3}$

2,320

RPa

5,500 to 7,600

5,500 to 7,600

15,200 to 19,300 (sic)

$\left(\mathrm{SiO}_{2}\right)$

$\left(\mathrm{Al}_{2} \mathrm{O}_{3}\right)$

$\left(\mathrm{TiO}_{2}\right)$

$\left(\mathrm{Fe}_{2} \mathrm{O}_{3}\right)$

( $\mathrm{CaO})$

(MgO)

$\left(\mathrm{Na}_{2} \mathrm{O}+\mathrm{R}_{2} \mathrm{O}+\mathrm{Li} \mathrm{i}_{2} \mathrm{O}\right) \quad 0.1$
77.08

1.7

16.6

0.1

0.7

3.7

0.1
Negligible

0.0 to -0.1

-0.1 to - 1.0 
t SHOT Products

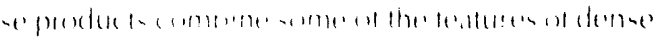

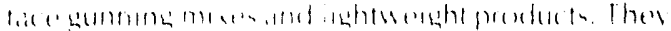

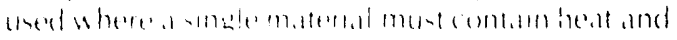

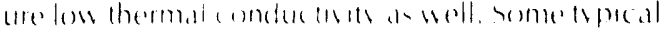

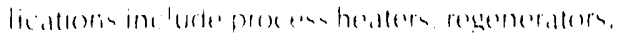

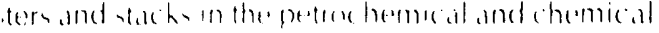
intrien.

\section{HOTGUN' Products}

These products are designed for low rebound application to hot surfaces for purposes of maintenance

Hot Gunning Applications:

- Slagline maintenance in induction furnaces and other melting equipment in the ferrous foundry

- Dressing upper sidewalls a. - t door jambs in alu-

minum reverb furnaces

- Cieneral maintenance in copper converters and copper reverb furnaces.

-WDLIGHTWEIGHT ES
efractory
iescription, applications:
combination of stan-
ard calcium aluminate
ement and calcined
ays. This material has
isulating value, as well
; high intermediate
!mperature strengths.
nlike most high caliber
ixes this product can
so be used in cast
istallations.

$2300 \mathrm{~F}$

$88 \mathrm{pcf}$

$8.10 \%$

$30 / 30$ psi

$5-10 \%$

pcf

96

88

psi

760

450

$450 @ 2500 \mathrm{~F}$

psi

4330

2750

2240@2500F

$\%$

Negligible

0.0

$+1.7 @ 2500 \mathrm{~F}$

$\%$
39.1
33.7
1.9
6.9
14.8
1.3
2.3
$H \cdot W^{\oplus 1} 28-75$

Description, applications: Another single lining material that by itself can perform like a backed up or two-component lin. ing. This blend of high temperature calcines. lightweight aggregate and high purity calcium aluminate cement features highest refractoriness combined with good insulation and strength.

$$
\begin{gathered}
2900 \mathrm{~F} \\
80 \mathrm{pcf} \\
10 \% \\
30 / 30 \mathrm{psi} \\
5 \% \\
\\
\\
\text { pcf } \\
83 \\
80 \\
\text { psi } \\
190 \\
60
\end{gathered}
$$

880@2550 F

$1820 @ 2850 \mathrm{~F}$

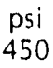

450

370

1510 (a) $2550 \mathrm{~F}$

$2470 @ 2850 F$

$\%$

Negligible

$-0.5$

$+0.5 @ 2550 \mathrm{~F}$

$-0.8 @ 2850 F$

$\%$
37.5
54.0
1.6
1.1
4.4
0.1
1.3

\section{(1)}

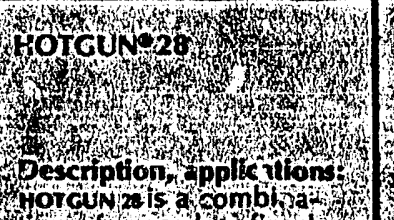
tion of superduty firectsy plustimproved ol cium xalumilate cement on - h tended for application to hot surfaces. It fea-m tures gond strength, high refractoriness and extremely low rebound

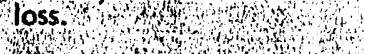
loss

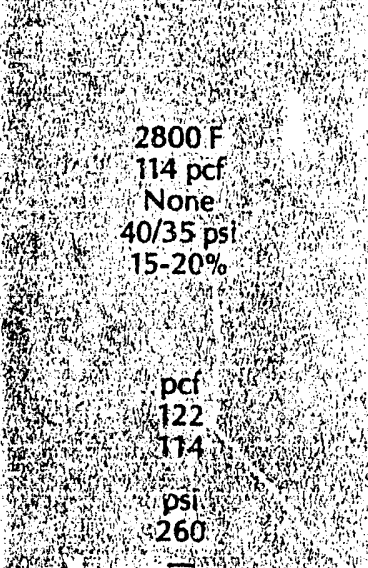

$240 @ 200 \%$

$900 \otimes 2730^{\circ} \mathrm{F}$

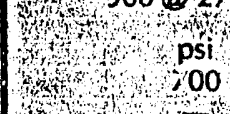

00

mot

$3290 @ 2730$ 'F

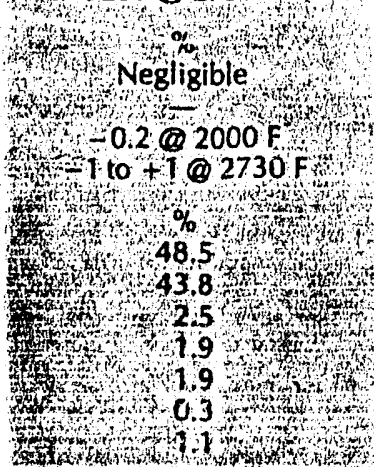

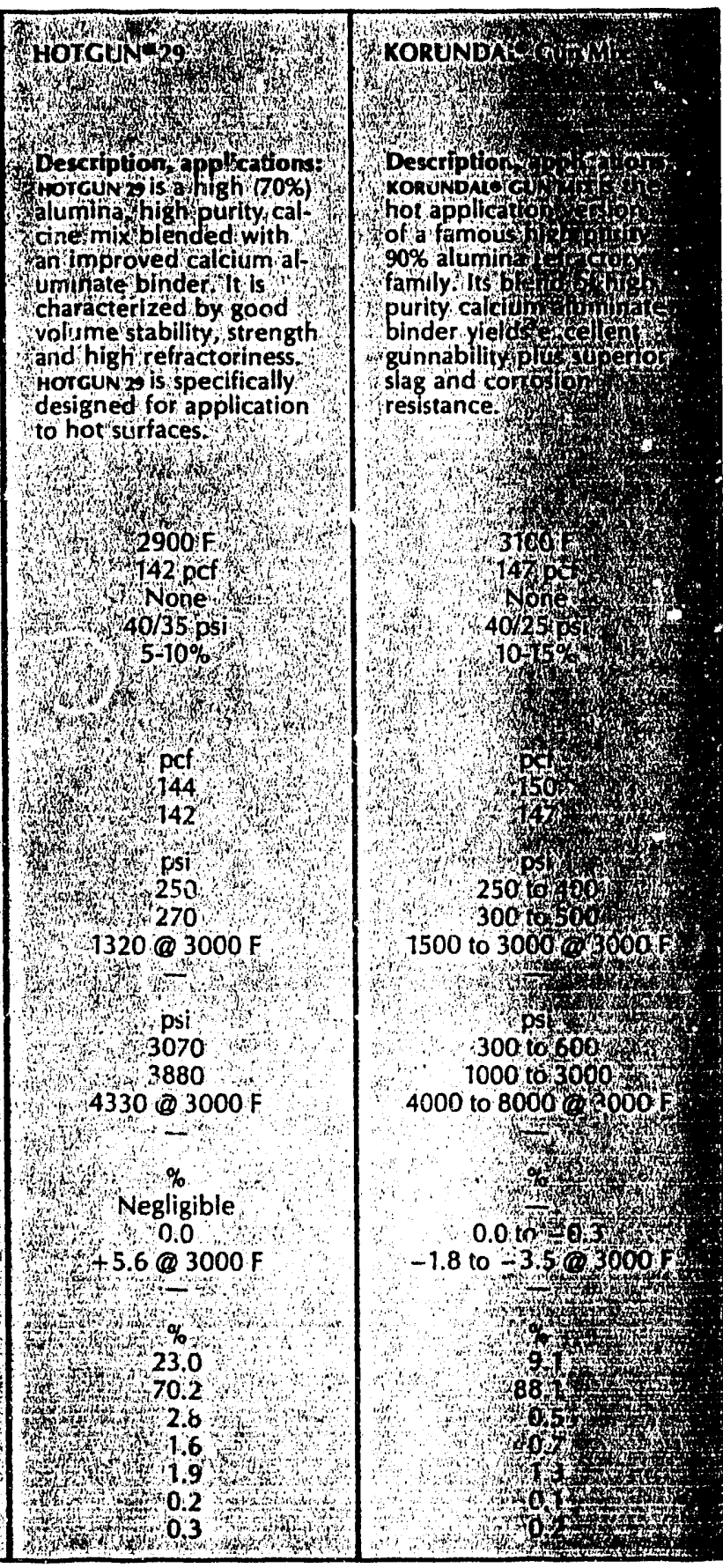

- Laboratory properties uf as-GunNed material

All data based on specimens resulting from actual gunning performed as de- ribed under Installation Data, Note 1. ASTM procedures, where applicable, were used for determination of data. All data are subject to reasonable de." wath wat, theretore, should not be ised for spectfication purposes. 
DENSE Products

For application as original hot face linings and for repairs in furnaces, process vessels and lines, stacks and process equipment of all kinds. These products provide graded resistance to elevated temperatures, abrasion and chemical atmospheres. When installed according to directions, these products will yield properties close to those shown in these tables. All products were designed for minimum loss due to rebounds during installation.

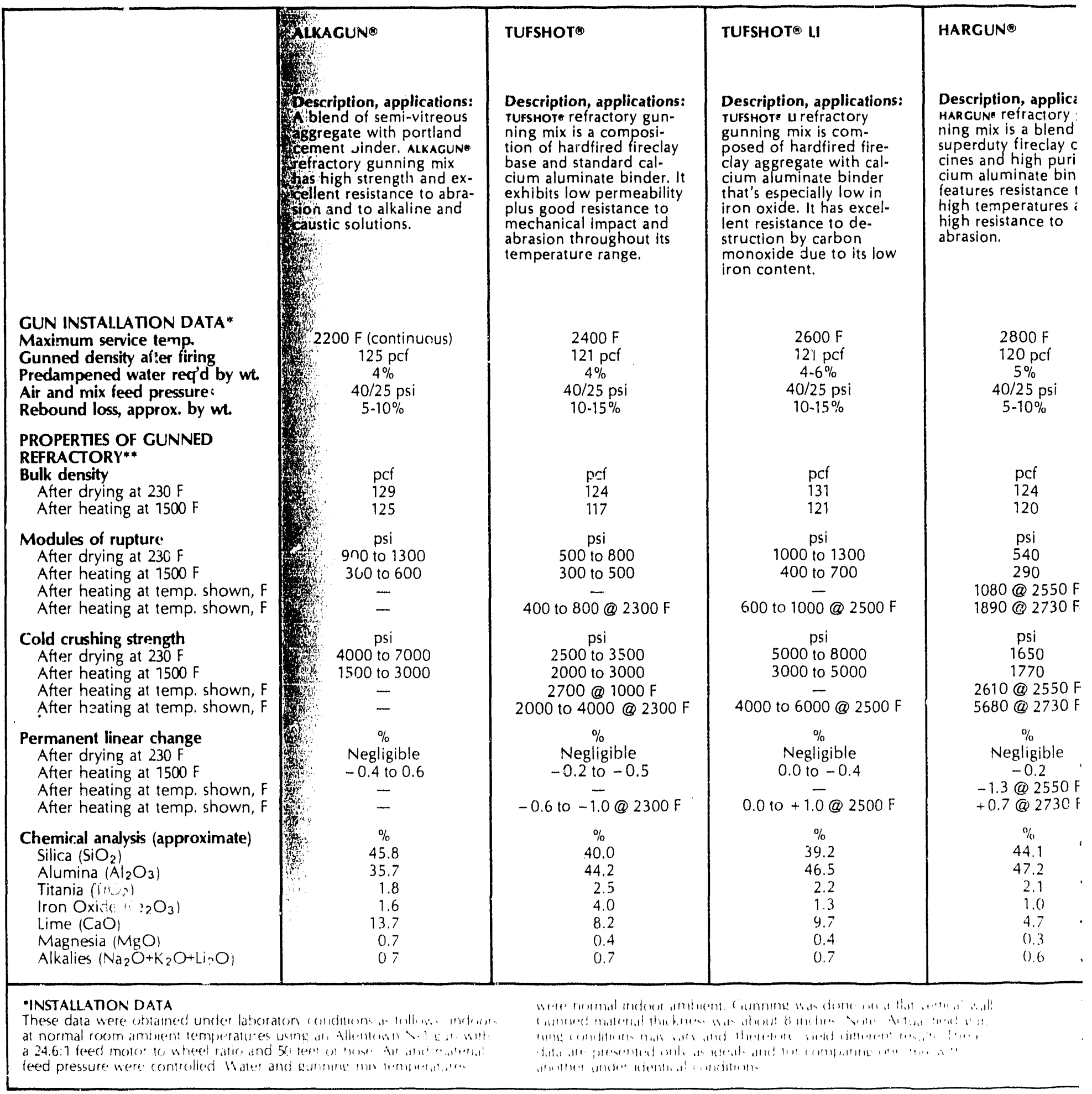




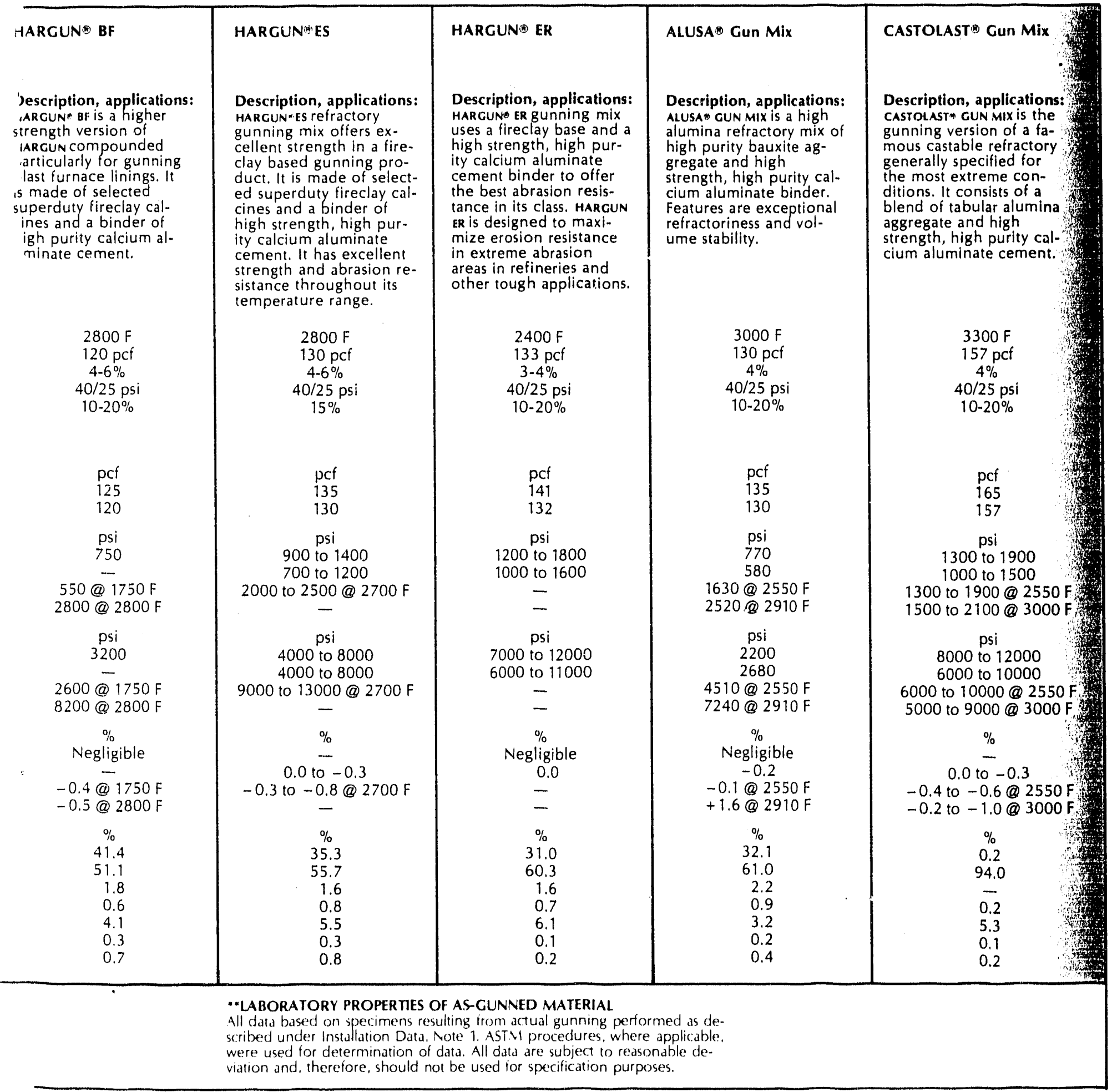


Fireclay Castable Refractories

\begin{tabular}{|c|c|c|c|c|}
\hline Brands & H-We ES Castable & H.W' ES Castable LI & KILNCAST-26 ${ }^{\circledR}$ & HARCAST \\
\hline $\begin{array}{l}\text { Maximum Service } \\
\text { Temperature }{ }^{\circ} \mathrm{F} \text {. }\end{array}$ & 2400 & 2600 & 2600 & 2800 \\
\hline $\begin{array}{l}\text { Approximate Amount } \\
\text { Water Required per } 100 \# \\
(46.26 \mathrm{Kg}) \text { U.S. Gal. }\end{array}$ & $1.75 \cdot 2.0$ & $1.5 \cdot 1.75$ & $1.25 \cdot 1.5$ & $1.5 \cdot 1.75$ \\
\hline $\begin{array}{l}\text { Lbs. Dry Mix } \\
\text { Required/cu. ft. }\end{array}$ & 121 & 122 & 130 & 123 \\
\hline Application & $C \cdot R \cdot T$ & C-R-T & $\mathrm{C}$ & $\mathrm{C}$ \\
\hline $\begin{array}{l}\text { Bulk Density, Ibs./cu. ft. } \\
\text { After Drying } \\
\text { at } 230^{\circ} \mathrm{F} .\left(110^{\circ} \mathrm{C}\right)\end{array}$ & 130 & 130 & 135 & 129 \\
\hline $\begin{array}{l}\text { MOR, psi } \\
\text { After Drying } \\
\text { at } 230^{\circ} \mathrm{F} .\left(110^{\circ} \mathrm{C}\right)\end{array}$ & $900-1200$ & $1000-1500$ & $800-1200$ & $800-1100$ \\
\hline $\begin{array}{l}\text { Atter Heating } \\
\text { at } 1000^{\circ} \mathrm{F} .\left(540^{\circ} \mathrm{C}\right)\end{array}$ & $500-800$ & 500.800 & $3 \cap 0-600$ & $300-450$ \\
\hline at $1500^{\circ} \mathrm{F} \cdot\left(815^{\circ} \mathrm{C}\right)$ & $500-800$ & $500 \cdot 800$ & $300 \cdot 600$ & $300-450$ \\
\hline at $2300^{\circ} \mathrm{F} \cdot\left(1260^{\circ} \mathrm{C}\right)$ & $500-800$ & & & \\
\hline at $2500^{\circ} \mathrm{F} .\left(1370^{\circ} \mathrm{C}\right)$ & & $600-1000$ & $700 \cdot 1200$ & \\
\hline at $2700^{\circ} \mathrm{F} .\left(1480^{\circ} \mathrm{C}\right)$ & & & & $600-900$ \\
\hline $\begin{array}{l}\text { Cold Crushing Strength, ps } \\
\text { After Drying } \\
\text { at } 230^{\circ} \mathrm{F} .\left(110^{\circ} \mathrm{C}\right)\end{array}$ & $4500-7000$ & $6000-9000$ & $6000-9000$ & $3500-5000$ \\
\hline $\begin{array}{l}\text { After Heating } \\
\text { at } 1000^{\circ} \mathrm{F} .\left(540^{\circ} \mathrm{C}\right)\end{array}$ & $3500-5000$ & $4000-6000$ & $4000-7000$ & $3000-4000$ \\
\hline at $1500^{\circ} \mathrm{F} \cdot\left(815^{\circ} \mathrm{C}\right)$ & $3100-4500$ & $4000-6000$ & $4000-7000$ & $3000 \cdot 4000$ \\
\hline at $2300^{\circ} \mathrm{F} \cdot\left(1260^{\circ} \mathrm{C}\right)$ & $2500-4000$ & & & \\
\hline at $2500^{\circ} \mathrm{F} \cdot\left(1370^{\circ} \mathrm{C}\right)$ & & $3000-5000$ & $2000-5000$ & \\
\hline at $2700^{\circ} \mathrm{F} .\left(1480^{\circ} \mathrm{C}\right)$ & & & & $7000 \cdot 9000$ \\
\hline $\begin{array}{l}\text { Permanent Linear Change o } \\
\text { Atter Drying } \\
\text { at } 230^{\circ} \mathrm{F} .\left(110^{\circ} \mathrm{C}\right)\end{array}$ & Negligible & Negligible & Negliglble & Negligible \\
\hline $\begin{array}{l}\text { After Heating } \\
\text { at } 1000^{\circ} \mathrm{F} .\left(540^{\circ} \mathrm{C}\right)\end{array}$ & 0.0 to -0.3 & $0.010-0.3$ & Negligible & Negligible \\
\hline at $1500^{\circ} \mathrm{F} .\left(815^{\circ} \mathrm{C}\right)$ & 0.0 to -0.3 & $0.010-0.3$ & Negligible & Negligible \\
\hline at $2300^{\circ} \mathrm{F} \cdot\left(1260^{\circ} \mathrm{C}\right)$ & +1.5 to -1.0 & & & \\
\hline at $2500^{\circ} \mathrm{F} \cdot\left(1370^{\circ} \mathrm{C}\right)$ & & $+1.010+3.0$ & +0.5 to +4.0 & $0.010+1.5$ \\
\hline 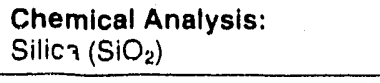 & $32.8 \%$ & $37.0 \%$ & $39.7 \%$ & $49.2 \%$ \\
\hline Alumina $\left(\mathrm{Al}_{2} \mathrm{O}_{3}\right)$ & 43.6 & 48.0 & 46.5 & 42.7 \\
\hline Titania $\left(\mathrm{TiO}_{2}\right)$ & 2.9 & 2.5 & 2.5 & 1.5 \\
\hline Iron Oxide $\left(\mathrm{Fe}_{2} \mathrm{O}_{3}\right)$ & 7.3 & 1.2 & 1.5 & 0.7 \\
\hline Lime $(\mathrm{CaO})$ & 12.0 & 10.3 & 8.5 & 5.0 \\
\hline Magnesia (MgO) & 0.4 & 0.4 & 0.5 & 0.3 \\
\hline Alkalies $\left(\mathrm{Na}_{2} \mathrm{O}+\mathrm{K}_{2} \mathrm{O}+\mathrm{Li}_{2} \mathrm{O}\right)$ & 1.0 & 0.6 & 0.8 & 0.6 \\
\hline
\end{tabular}

Application methods: C, Cast, R, Rammed, and T, Trowelled. For Gunning reter to Harbison-Walkers' "High Caliber Gunning Mix" Brochure.

- Limited Data

All data based on cast specimens. ASTM procedures, where applicable, used to delermination of data. All data subject to reasonable deviation and, therefore. should not be used for specification purposes.

tThis castable is bonded with high purity strength calciuin aluminate cement. If proper procedures for preparation, application and heal.up of this castable are not observed, steam spalling during heal-up may occur. (See instructions on product bag wrapping) 


\section{Fireclay Castable Refractories}

\begin{tabular}{|c|c|c|c|}
\hline Brands & HAACAST' C & HARCAST 'ES & HARCAST 'ER* $\dagger$ \\
\hline $\begin{array}{l}\text { Maximum Service } \\
\text { Temperature }{ }^{\circ} \mathrm{F} \text {. }\end{array}$ & 2800 & 2800 & 2400 \\
\hline $\begin{array}{l}\text { Approximate Amount } \\
\text { Water Required per } 100 \# \\
(46.26 \mathrm{Kg}) \text { U.S. Gal. }\end{array}$ & $1.5 \cdot 1.75$ & $1.25-1.5$ & $1.25 \cdot 1.5$ \\
\hline $\begin{array}{l}\text { Lbs. Dry Mix } \\
\text { Required/cu. ft. }\end{array}$ & 129 & 132 & 135 \\
\hline Application & C & C.T & C \\
\hline $\begin{array}{l}\text { Bulk Density, lbs./cu. ft. } \\
\text { After Drying } \\
\text { at } 230^{\circ} \mathrm{F} .\left(110^{\circ} \mathrm{C}\right)\end{array}$ & 133 & 138 & 142 \\
\hline $\begin{array}{l}\text { MOR, psi } \\
\text { After Drying } \\
\text { at } 230^{\circ} \mathrm{F} .\left(110^{\circ} \mathrm{C}\right)\end{array}$ & $800-1100$ & $1000 \cdot 1500$ & 1850 \\
\hline $\begin{array}{l}\text { After Heating } \\
\text { at } 1000^{\circ} \mathrm{F} .\left(540^{\circ} \mathrm{C}\right)\end{array}$ & $300-500$ & $900-1300$ & \\
\hline at $1500^{\circ} \mathrm{F} \cdot\left(815^{\circ} \mathrm{C}\right)$ & $300-500$ & $900-1300$ & 2310 \\
\hline at $2700^{\circ} \mathrm{F} \cdot\left(1480^{\circ} \mathrm{C}\right)$ & $1000-1300$ & $1200-1900$ & 3710 \\
\hline $\begin{array}{l}\text { Cold Crushing Strength, psl } \\
\text { After Drying } \\
\text { at } 230^{\circ} \mathrm{F} .\left(110^{\circ} \mathrm{C}\right)\end{array}$ & $5000 \cdot 7000$ & $6000-9000$ & 8740 \\
\hline $\begin{array}{l}\text { After Heating } \\
\text { at } 1000^{\circ} \mathrm{F} .\left(540^{\circ} \mathrm{C}\right)\end{array}$ & $3000-5000$ & $5000-7000$ & \\
\hline at $1500^{\circ} \mathrm{F},\left(815^{\circ} \mathrm{C}\right)$ & $3000-5000$ & $5000-7000$ & 9190 \\
\hline at $2700^{\circ} \mathrm{F} \cdot\left(1480^{\circ} \mathrm{C}\right)$ & $4000-7000$ & $8000-10,000$ & 9400 \\
\hline $\begin{array}{l}\text { Permanent Linear Change } \% \\
\text { After Drying } \\
\text { at } 230^{\circ} \mathrm{F} .\left(110^{\circ} \mathrm{C}\right)\end{array}$ & Negligible & Negligible & Negligible \\
\hline $\begin{array}{l}\text { After Heating } \\
\text { at } 1000^{\circ} \mathrm{F} .\left(540^{\circ} \mathrm{C}\right)\end{array}$ & Negligible & Negligible & \\
\hline at $1500^{\circ} \mathrm{F} \cdot\left(815^{\circ} \mathrm{C}\right)$ & Negligible & Negligible & 0.0 \\
\hline at $2700^{\circ} \mathrm{F} \cdot\left(1480^{\circ} \mathrm{C}\right)$ & $+1.010+2.0$ & -1.5 to 0.0 & -4.4 \\
\hline \multicolumn{4}{|l|}{ Chemical Analysis: } \\
\hline Silica $\left(\mathrm{SiO}_{2}\right)$ & $49.2 \%$ & $35.6 \%$ & $31.0 \%$ \\
\hline Alumina $\left(\mathrm{Al}_{2} \mathrm{O}_{3}\right)$ & 42.7 & 55.6 & 60.3 \\
\hline Titania $\left(\mathrm{TiO}_{2}\right)$ & 1.5 & 1.6 & 1.6 \\
\hline Iron Oxide $\left(\mathrm{Fe}_{2} \mathrm{O}_{3}\right)$ & 0.7 & 0.8 & 0.7 \\
\hline Lime $(\mathrm{CaO})$ & 5.0 & 5.4 & 6.1 \\
\hline Magnesia (MgO) & 0.3 & 0.3 & 0.1 \\
\hline Alkalies $\left(\mathrm{Na}_{2} \mathrm{O}+\mathrm{K}_{2} \mathrm{O}+\mathrm{Li}_{2} \mathrm{O}\right)$ & 0.6 & 0.7 & 0.2 \\
\hline
\end{tabular}

Application methods: C, Cast; R, Rammed, and T, Trowelled. For Gunning refer to Harbison-Walkers' "High Caliber Gunning Mix" Brochure

- Limited Data

All data based on cast specimens. ASTM procedures, where applicable, used to determination of data.

All data subject to reasonable deviation and, therefore, should not be used for specification purposes.

tThis castable is bonded with high purity strength calcium aluminate cement. If proper procedures for preparation, application and heat-up of this castable are not observed, steam spalling during heat-up may occur. (Se日 instructions on product bag wrapping). 


\section{Harbison-Walker High-Alumina Castable Refractories}

\begin{tabular}{|c|c|c|c|c|c|}
\hline Brands & $\begin{array}{l}H \cdot W * \text { High. } \\
\text { Alumina Castable }\end{array}$ & $\begin{array}{l}\text { UFALA } \\
\text { Castable" }\end{array}$ & $\begin{array}{l}\text { ALUSA } \\
\text { Castable }\end{array}$ & $\begin{array}{l}\text { CASTOLAST * G*† } \\
\text { WIth C.CLRED }\end{array}$ & $\begin{array}{l}\text { CASTOLAST " GC. } \\
\text { With C.CUAED' }\end{array}$ \\
\hline $\begin{array}{l}\text { Maximum Service } \\
\text { Temperature }{ }^{\circ} \mathrm{F} \text {. }\end{array}$ & 3000 & 3100 & 3200 & 3300 & 3300 \\
\hline $\begin{array}{l}\text { Approximaie Amount } \\
\text { Water Required per } 100 \# \\
(46.26 \mathrm{Kg}) \text { U.S. Gal. }\end{array}$ & $1.25 \cdot 1.5$ & $1.0 \cdot 1.25$ & $1.0 \cdot 1.25$ & $1.0 \cdot 1.25$ & $.75 \cdot 1.0$ \\
\hline $\begin{array}{l}\text { Lbs. Dry Mix } \\
\text { Required/cu. ft. }\end{array}$ & 137 & 143 & 143 & 160 & 170 \\
\hline Application & C.T & C.T & C.T & C.T & C.T \\
\hline $\begin{array}{l}\text { Bulk Density, lbs./cu. ft. } \\
\text { Atter Drying } \\
\text { at } 230^{\circ} \mathrm{F} .\left(110^{\circ} \mathrm{C}\right)\end{array}$ & 139 & 144 & 146 & 165 & 174 \\
\hline $\begin{array}{l}\text { MOR, psi } \\
\text { After Drying } \\
\text { at } 230^{\circ} \mathrm{F} \cdot\left(110^{\circ} \mathrm{C}\right)\end{array}$ & $400-800$ & 600.900 & $400-800$ & $1400-1800$ & $1200-1700^{\circ}$ \\
\hline $\begin{array}{l}\text { After Heating } \\
\text { at } 1000^{\circ} \mathrm{F} .\left(540^{\circ} \mathrm{C}\right)\end{array}$ & $250-550$ & & $400-800$ & & \\
\hline at $1500^{\circ} \mathrm{F} \cdot\left(815^{\circ} \mathrm{C}\right)$ & $250-550$ & & $400-800$ & $1300-1700$ & $1200 \cdot 1700$ \\
\hline at $3000^{\circ} \mathrm{F} .\left(1650^{\circ} \mathrm{C}\right)$ & $1000-1800$ & & & & $1100 \cdot 1600$ \\
\hline at $3140^{\circ} \mathrm{F} .\left(1725^{\circ} \mathrm{C}\right)$ & & & $1700 \cdot 2100$ & $1300-1700$ & \\
\hline $\begin{array}{l}\text { Cold Crushing Strength, psi } \\
\text { After Drying } \\
\text { at } 230^{\circ} \mathrm{F} .\left(110^{\circ} \mathrm{C}\right)\end{array}$ & $1500-3500$ & $3500-5500$ & $2000-5000$ & $7000 \cdot 11,000$ & $7000-12,000$ \\
\hline $\begin{array}{l}\text { After Heating } \\
\text { at } 1000^{\circ} \mathrm{F} .\left(540^{\circ} \mathrm{C}\right)\end{array}$ & $1700-3000$ & & $2000-4000$ & & \\
\hline at $1500^{\circ} \mathrm{F} \cdot\left(815^{\circ} \mathrm{C}\right)$ & $1700-3000$ & & $2000-4000$ & $7000 \cdot 11,000$ & $7000-12,000$ \\
\hline at $3000^{\circ} \mathrm{F} .\left(1650^{\circ} \mathrm{C}\right)$ & $6000 \cdot 9000$ & 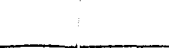 & & & $5000-9000$ \\
\hline at $3140^{\circ} \mathrm{F} .\left(1725^{\circ} \mathrm{C}\right)$ & & & $5000 \cdot 9000$ & $6000-9000$ & \\
\hline $\begin{array}{l}\text { Permanent Linear Change } \\
\text { After Drying } \\
\text { at } 230^{\circ} \mathrm{F} \cdot\left(110^{\circ} \mathrm{C}\right)\end{array}$ & Negligible & & Negligible & & \\
\hline $\begin{array}{l}\text { Atter Heating } \\
\text { at } 1000^{\circ} \mathrm{F} .\left(540^{\circ} \mathrm{C}\right)\end{array}$ & Negligible & & Negligible & & \\
\hline at $1600^{\circ} \mathrm{F} \cdot\left(815^{\circ} \mathrm{C}\right)$ & 0.0 to -0.5 & Negyligible & Negligible & Negligible & Negligible \\
\hline at $3000^{\circ} \mathrm{F} .\left(1650^{\circ} \mathrm{C}\right)$ & +1.0 to +3.5 & $0.0 t$ to 0.7 & & & $-0.210-1.2$ \\
\hline at $3140^{\circ} \mathrm{F} .\left(1725^{\circ} \mathrm{C}\right)$ & & & $-0.510+2.0$ & 0.0 to -1.0 & \\
\hline $\begin{array}{l}\text { Chemical Árialysis: } \\
\text { Silica }\left(\mathrm{SiO}_{2}\right)\end{array}$ & $31.5 \%$ & $34.9 \%$ & $23.3 \%$ & $0.2 \%$ & $0.1 \%$ \\
\hline Alumina $\left(\mathrm{Al}_{2} \mathrm{O}_{3}\right)$ & 60.5 & 59.3 & 70.8 & 94.0 & 94.9 \\
\hline Titania $\left(\mathrm{TiO}_{2}\right)$ & 2.9 & 2.3 & 2.4 & Trace & Trace \\
\hline Iron Oxide $\left(\mathrm{Fe}_{2} \mathrm{O}_{3}\right)$ & 1.1 & 1.0 & 1.0 & 0.2 & 0.2 \\
\hline Lime $(\mathrm{CaO})$ & 3.5 & 2.2 & 2.2 & 5.3 & 4.5 \\
\hline Magnesia (MgO) & 0.2 & & 0.1 & 0.1 & 0.1 \\
\hline Alkalies $\left(\mathrm{Na}_{2} \mathrm{O}+\mathrm{K}_{2} \mathrm{O}+\mathrm{Li}_{2} \mathrm{O}\right)$ & 0.3 & 0.2 & 0.2 & 0.2 & 0.2 \\
\hline
\end{tabular}

Application methods: C. Cast: R. Rarmmed, and T. Trowelled. For Gunning reler to Harbison-Walkers' "High Caliber Gunning Mix" Brochure.

- Limited Data

All data based on cast specimens. ASTM procedures. where applicable, used to determination of data.

All data subject to reasonable deviation and. therefore, should not be used for specification purposes.

$\uparrow$ This castable is bonded with high purity strength calcium aluminate cement. If proper procedures for preparation, application and heat.up of this castable are not observed. steam spalling during heat-up may occur. (See instructions on product bag wrapping). 
Harbison-Walker Lightweight, Insulating Castables

\begin{tabular}{|c|c|c|c|c|c|}
\hline Brands & $\begin{array}{c}H \cdot W \cdot \text { Lightweight } \\
\text { Castable } 16\end{array}$ & $\begin{array}{c}H \cdot W^{0} \text { Lightwelght } \\
\text { Castable } 20\end{array}$ & $\begin{array}{l}H \cdot W^{c} \text { Lightweight } \\
\text { Castable } 22\end{array}$ & $\begin{array}{c}\text { H.W Lightwolght } \\
\text { Castable } 26\end{array}$ & $\begin{array}{c}\text { H.W Llghtweight } \\
\text { Castable } 28\end{array}$ \\
\hline $\begin{array}{l}\text { Meximum Service } \\
\text { Temperature }{ }^{\circ} \mathrm{F} \text {. }\end{array}$ & 1600 & 2000 & 2200 & 2600 & 2800 \\
\hline $\begin{array}{l}\text { Approximate Amou } \\
\text { Water Required per } \\
(46.26 \mathrm{Kg}) \text { U.S. Gal. }\end{array}$ & $4.0 \cdot 5.0$ & $5.0 \cdot 6.5$ & $2.5 \cdot 3.0$ & $3.0 \cdot 3.5$ & $3.0 \cdot 3.5$ \\
\hline $\begin{array}{l}\text { Lbs. Dry Mlx } \\
\text { Required/cu. } \mathrm{ft} \text {. }\end{array}$ & 23 & 32 & 56 & 55 & 85 \\
\hline Application & C-T & C.T & C.T & C.T & C.T \\
\hline $\begin{array}{l}\text { Bulk Density, lbs./c } \\
\text { After Drying } \\
\text { at } 230^{\circ} \mathrm{F} .\left(110^{\circ} \mathrm{C}\right)\end{array}$ & 25 & 37 & 62 & 56 & 93 \\
\hline $\begin{array}{l}\text { MOR, psl } \\
\text { Atter Drying } \\
\text { at } 230^{\circ} \mathrm{F} .\left(110^{\circ} \mathrm{C}\right) \\
\end{array}$ & $20-60$ & $60 \cdot 100$ & $130-200$ & $90 \cdot 200$ & $200 \cdot 350$ \\
\hline $\begin{array}{l}\text { After Heating } \\
\text { at } 1000^{\circ} \mathrm{F} .\left(540^{\circ} \mathrm{C}\right)\end{array}$ & $10 \cdot 50$ & $30-60$ & $100 \cdot 150$ & $50 \cdot 100$ & $100 \cdot 150$ \\
\hline at $1500^{\circ} \mathrm{F} .\left(815^{\circ} \mathrm{C}\right)$ & 10.50 & $30 \cdot 60$ & $110 \cdot 170$ & $50 \cdot 100$ & $100 \cdot 150$ \\
\hline at $1900^{\circ} \mathrm{F} \cdot\left(1040^{\circ} \mathrm{C}\right)$ & & 30.60 & & & \\
\hline at $2100^{\circ} \mathrm{F} \cdot\left(1150^{\circ} \mathrm{C}\right)$ & & & $110 \cdot 170$ & & \\
\hline at $2500^{\circ} \mathrm{F} \cdot\left(1370^{\circ} \mathrm{C}\right)$ & & & & $200-400$ & \\
\hline at $2700^{\circ} \mathrm{F} \cdot\left(1480^{\circ} \mathrm{C}\right)$ & & & & & $800 \cdot 1000$ \\
\hline $\begin{array}{l}\text { Cold Crushing Stre } \\
\text { After Drying } \\
\text { at } 230^{\circ} \mathrm{F} .\left(110^{\circ} \mathrm{C}\right)\end{array}$ & 40.120 & 200.300 & $500-800$ & $200-400$ & $500 \cdot 1000$ \\
\hline $\begin{array}{l}\text { After Heating } \\
\text { at } 1000^{\circ} \mathrm{F} .\left(540^{\circ} \mathrm{C}\right)\end{array}$ & $70-110$ & $150 \cdot 200$ & $300-600$ & $200 \cdot 300$ & $500 \cdot 700$ \\
\hline at $1500^{\circ} \mathrm{F} .\left(815^{\circ} \mathrm{C}\right)$ & $30-100$ & $150 \cdot 200$ & $300-550$ & $200-300$ & $400 \cdot 650$ \\
\hline at $1900^{\circ} \mathrm{F} \cdot\left(1040^{\circ} \mathrm{C}\right)$ & & $100 \cdot 150$ & & & \\
\hline at $2100^{\circ} \mathrm{F} .\left(1150^{\circ} \mathrm{C}\right)$ & & & $250-450$ & & \\
\hline at $2500^{\circ} \mathrm{F} \cdot\left(1370^{\circ} \mathrm{C}\right)$ & & & & $500-1000$ & \\
\hline at $2700^{\circ} \mathrm{F} \cdot\left(1480^{\circ} \mathrm{C}\right)$ & & & & & $2000 \cdot 3000$ \\
\hline $\begin{array}{l}\text { Permanent Linear } \mathrm{C} \\
\text { After Drying } \\
\text { at } 230^{\circ} \mathrm{F} .\left(110^{\circ} \mathrm{C}\right)\end{array}$ & Negligible & Negligible & Negligible & Negligible & Negligible \\
\hline $\begin{array}{l}\text { After Heating } \\
\text { at } 1000^{\circ} \mathrm{F},\left(540^{\circ} \mathrm{C}\right)\end{array}$ & -0.5 to -1.0 & $-0.110-0.5$ & -0.2 to -0.5 & $-0.210-0.4$ & $0.010-0.3$ \\
\hline at $1500^{\circ} \mathrm{F} \cdot\left(815^{\circ} \mathrm{C}\right)$ & -1.0 to -1.5 & $-0.210-0.7$ & $-0.310-0.7$ & -0.2 to -0.5 & 0.0 to -0.3 \\
\hline at $1900^{\circ} \mathrm{F} \cdot\left(1040^{\circ} \mathrm{C}\right)$ & & $-1.510-2.0$ & & & \\
\hline at $2100^{\circ} \mathrm{F} \cdot\left(1150^{\circ} \mathrm{C}\right)$ & & & -0.5 to -1.5 & & \\
\hline at $2500^{\circ} \mathrm{F} \cdot\left(1370^{\circ} \mathrm{C}\right)$ & & . & & $+1.010+3.0$ & \\
\hline at $2700^{\circ} \mathrm{F},\left(1480^{\circ} \mathrm{C}\right)$ & & & & & $-2.010+2.0$ \\
\hline $\begin{array}{l}\text { Thermal Conductiv } \\
\text { at } 500^{\circ} \mathrm{F} .\left(246^{\circ} \mathrm{C}\right)\end{array}$ & $\mathrm{ft}^{\circ}{ }^{\circ} \mathrm{F} . / \mathrm{in}$. & 1.15 & 1.44 & 1.47 & 3.18 \\
\hline at $1000^{\circ} \mathrm{F} \cdot\left(540^{\circ} \mathrm{C}\right)$ & 1.30 & 1.33 & 1.63 & 1.68 & 3.41 \\
\hline at $1500^{\circ} \mathrm{F} \cdot\left(815^{\circ} \mathrm{C}\right)$ & & 1.54 & 1.86 & 1.94 & 3.76 \\
\hline at $2000^{\circ} \mathrm{F} \cdot\left(1093^{\circ} \mathrm{C}\right)$ & & 1.80 & 2.18 & 2.24 & 4.22 \\
\hline
\end{tabular}

Application methods: C, Cast: A. Rammed, and T, Trowelled. For Gunning reler to Harbison-Walkers' "High Caliber Gunning Mix" Brochure

- Limited Data

All data based on cast specimens. ASTM procedures. where applicable, used to determination ol data All data subject 10 reasonable de viation and. Iheretore. should not be used lor specification purposes.

tThis castable is bonded with high purity strength calcium aluminate cement. If proper procedures for preparation, application and heal.up of this castable are not observed. sleam spalling during heat.up may occur. (See instructions on product bag wrapping) 


\section{Harbison-Walker Lightweight, Insulating Castables}

\begin{tabular}{|c|c|c|c|c|}
\hline Brands & $\begin{array}{c}H \cdot W \cdot \text { Lightweight } \\
\text { Castable } 30\end{array}$ & $\begin{array}{c}\text { H-W Lightweight } \\
\text { Cpistable } 33\end{array}$ & $\begin{array}{c}\text { H-W Lightweight } \\
\text { Castable LI }\end{array}$ & $\begin{array}{l}\text { H-W Lightweight } \\
\text { ES Refractory }\end{array}$ \\
\hline $\begin{array}{l}\text { Maximum Service } \\
\text { Temperature }{ }^{\circ} \mathrm{F} \text {. }\end{array}$ & 3000 & 3300 & 2200 & 2300 \\
\hline $\begin{array}{l}\text { Approximate Amount } \\
\text { Water Fequired per } 100 \# \\
(46.26 \mathrm{Kg}) \text { U.S. Gal. }\end{array}$ & $3.0 \cdot 3.5$ & $2.0 \cdot 2.5$ & $4.0 \cdot 4.5$ & $3.5 \cdot 4.0$ \\
\hline $\begin{array}{l}\text { Lbs. Dry Mix } \\
\text { Required/cu. ft. }\end{array}$ & 88 & 91 & 44 & 76 \\
\hline Application & $\mathrm{C}$ & $\mathrm{C}$ & $\mathrm{C}$ & 0 \\
\hline $\begin{array}{l}\text { Bulk Density, lbs./cu. ft. } \\
\text { After Drying } \\
\text { at } 230^{\circ} \mathrm{F} .\left(110^{\circ} \mathrm{C}\right)\end{array}$ & 92 & 102 & 52 & 80 \\
\hline $\begin{array}{l}\text { MOR, psi } \\
\text { After Drying } \\
\text { at } 230^{\circ} \mathrm{F} .\left(110^{\circ} \mathrm{C}\right)\end{array}$ & $150-250$ & $400-800$ & $100-250$ & $300-500$ \\
\hline $\begin{array}{l}\text { After Heating } \\
\text { at } 1000^{\circ} \mathrm{F} .\left(540^{\circ} \mathrm{C}\right)\end{array}$ & $50-100$ & & $50-100$ & $200-400$ \\
\hline at $1500^{\circ} \mathrm{F} \cdot\left(815^{\circ} \mathrm{C}\right)$ & $100 \cdot 150$ & $300-400$ & $50-100$ & $200-400$ \\
\hline at $2100^{\circ} \mathrm{F} \cdot\left(1150^{\circ} \mathrm{C}\right)$ & & & 50.100 & \\
\hline at $2900^{\circ} \mathrm{F} \cdot\left(1595^{\circ} \mathrm{C}\right)$ & $700 \cdot 1300$ & & & \\
\hline at $3000^{\circ} \mathrm{F},\left(1650^{\circ} \mathrm{C}\right)$ & & 200.400 & & \\
\hline at $3200^{\circ} \mathrm{F} .\left(1760^{\circ} \mathrm{C}\right)$ & & 200.400 & & \\
\hline $\begin{array}{l}\text { Cold Crushing Strength, } \\
\text { After Drylng } \\
\text { at } 230^{\circ} \mathrm{F} .\left(110^{\circ} \mathrm{C}\right)\end{array}$ & $500-1000$ & $2500-3500$ & $400-600$ & $1100-2100$ \\
\hline $\begin{array}{l}\text { After Heating } \\
\text { at } 1000^{\circ} \mathrm{F} .\left(540^{\circ} \mathrm{C}\right)\end{array}$ & $400-600$ & 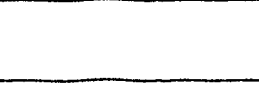 & 300.400 & $800 \cdot 1500$ \\
\hline at $1500^{\circ} \mathrm{F} .\left(815^{\circ} \mathrm{C}\right)$ & $500-700$ & $2000-2800$ & $300-400$ & $800-1500$ \\
\hline at $2100^{\circ} \mathrm{F} .\left(1150^{\circ} \mathrm{C}\right)$ & & & $200-300$ & \\
\hline at $2900^{\circ} \mathrm{F} .\left(1595^{\circ} \mathrm{C}\right)$ & $2100-2600$ & & & \\
\hline at $3000^{\circ} \mathrm{F} \cdot\left(1650^{\circ} \mathrm{C}\right)$ & & $1500-2500$ & & \\
\hline at $3200^{\circ} \mathrm{F} .\left(1760^{\circ} \mathrm{C}\right)$ & & $2000-2800$ & & \\
\hline $\begin{array}{l}\text { Permanent Linear Chang } \\
\text { After Drying } \\
\text { at } 230^{\circ} \mathrm{F} .\left(110^{\circ} \mathrm{C}\right)\end{array}$ & Negligible & Negligible & Negliglble & Negligible \\
\hline $\begin{array}{l}\text { After Heating } \\
\text { at } 1000^{\circ} \mathrm{F} \cdot\left(540^{\circ} \mathrm{C}\right)\end{array}$ & 0.0 to -0.2 & & -0.2 to -0.4 & -0.1 to -0.4 \\
\hline at $1500^{\circ} \mathrm{F} \cdot\left(815^{\circ} \mathrm{C}\right)$ & 0.0 to -0.2 & Negligible & $-0.210+0.2$ & -0.1 to -0.4 \\
\hline at $2100^{\circ} \mathrm{F} \cdot\left(1150^{\circ} \mathrm{C}\right)$ & & & -1.0 to -2.0 & \\
\hline at $2900^{\circ} \mathrm{F} \cdot\left(1595^{\circ} \mathrm{C}\right)$ & $-1.010+2.0$ & & & \\
\hline at $3000^{\circ} \mathrm{F} \cdot\left(1650^{\circ} \mathrm{C}\right)$ & & +1.0 to +2.0 & & \\
\hline at $3200^{\circ} \mathrm{F} .\left(1760^{\circ} \mathrm{C}\right)$ & & 0.0 to +10 & & \\
\hline $\begin{array}{l}\text { Thermal Conductivity: B } \\
\text { at } 500^{\circ} \mathrm{F} \cdot\left(246^{\circ} \mathrm{C}\right)\end{array}$ & $\begin{array}{l}\circ \\
\end{array}$ & 6.3 & 1.67 & 2.40 \\
\hline at $1000^{\circ} \mathrm{F} .\left(540^{\circ} \mathrm{C}\right)$ & 3.61 & 5.4 & 1.80 & 2.58 \\
\hline at $1500^{\circ} \mathrm{F} .\left(815^{\circ} \mathrm{C}\right)$ & 3.87 & 5.05 & 1.98 & 2.70 \\
\hline at $2000^{\circ} \mathrm{F} \cdot\left(1093^{\circ} \mathrm{C}\right)$ & 4.20 & 5.05 & 2.20 & 2.90 \\
\hline
\end{tabular}

Application methods: C, Cast; R, Rammed, and T, Trowelled. For Gunning refer to Harbison-Walkers' "High Caliber Gunning Mix" Brochure.

- Limited Data

All data based on cast specimens. ASTM procedures, where applicable, used to determination of data.

All data subject to reasonable deviation and, therefore, should not be used for specification purposes.

tThis castable is bonded with high purity strength calcium aluminate cement. If proper procedures for preparation, application and heat-up of this castable are not observed, steam spalling during heat-up may occur. (See instructions on product bag wrapping). 


\section{Harbison-Walker Special Castable Refractories}

\begin{tabular}{|c|c|c|c|c|c|}
\hline Brands & ALKACAST & $\begin{array}{l}\text { VISIL: } \\
\text { Castable }\end{array}$ & $\begin{array}{c}\text { Harbison-Walker } \\
17.67^{*}\end{array}$ & HARMIX AL & $\begin{array}{l}\text { HARCHROME } \\
\text { Castablet }\end{array}$ \\
\hline $\begin{array}{l}\text { Maximum Service } \\
\text { Temperature }{ }^{\circ} \mathrm{F} \text {. }\end{array}$ & 1000 & 2000 & 2000 & & 2500 \\
\hline $\begin{array}{l}\text { Approximate Amount } \\
\text { Water Requirad per } 100 \# \\
(46.26 \mathrm{Kg}) \text { U.S. Gal. }\end{array}$ & $1.75 \cdot 2.0$ & $1.25 \cdot 1.5$ & & .75 & $1.25 \cdot 1.5$ \\
\hline $\begin{array}{l}\text { Lbs. Dry Mix } \\
\text { Required/cu. ft. }\end{array}$ & 117 & 112 & & 165 & 161 \\
\hline Application & C.T & C.T & $\mathrm{C}$ & C & C \\
\hline $\begin{array}{l}\text { Bulk Density, Ibs./cu, ft. } \\
\text { Atter Drying } \\
\text { at } 230^{\circ} \mathrm{F} .\left(110^{\circ} \mathrm{C}\right)\end{array}$ & 120 & 120 & 117 & 168 & 173 \\
\hline $\begin{array}{l}\text { MOR, psi } \\
\text { Atter Drying } \\
\text { at } 230^{\circ} \mathrm{F} .\left(110^{\circ} \mathrm{C}\right)\end{array}$ & $1000 \cdot 1400$ & $800 \cdot 1200$ & & $800 \cdot 1100$ & $10 \cap 0-1300$ \\
\hline $\begin{array}{l}\text { After Heating } \\
\text { at } 1000^{\circ} \mathrm{F} .\left(540^{\circ} \mathrm{C}\right)\end{array}$ & $600-1000$ & $200-500$ & & & 550.750 \\
\hline at $1500^{\circ} \mathrm{F} \cdot\left(815^{\circ} \mathrm{C}\right)$ & & 200.500 & & $500-800$ & $550-750$ \\
\hline at $2000^{\circ} \mathrm{F} \cdot\left(1093^{\circ} \mathrm{C}\right)$ & & & & $500-800$ & \\
\hline at $2300^{\circ} \mathrm{F} .\left(1260^{\circ} \mathrm{C}\right)$ & & $300-500$ & & & \\
\hline $\begin{array}{l}\text { Cold Crushing Strength, psi } \\
\text { After Drying } \\
\text { at } 230^{\circ} \mathrm{F},\left(110^{\circ} \mathrm{C}\right)\end{array}$ & $5500-8000$ & $6000-9000$ & & $4000-7000$ & $6000 \cdot 8000$ \\
\hline $\begin{array}{l}\text { After Heating } \\
\text { at } 1000^{\circ} \mathrm{F} .\left(540^{\circ} \mathrm{C}\right)\end{array}$ & $4000-6500$ & $4000-6000$ & & & $4000 \cdot 6000$ \\
\hline at $1500^{\circ} \mathrm{F} \cdot\left(815^{\circ} \mathrm{C}\right)$ & & $3500-5500$ & $4000-7000$ & $3000-5000$ & $4000-6000$ \\
\hline at $\angle 000^{\circ} \mathrm{F} \cdot\left(1093^{\circ} \mathrm{C}\right)$ & & & & $3000-5000$ & \\
\hline at $2300^{\circ} \mathrm{F} \cdot\left(1260^{\circ} \mathrm{C}\right)$ & & $2500-4000$ & & & \\
\hline $\begin{array}{l}\text { Permanent Linear Change } \% \\
\text { After Drying } \\
\text { at } 230^{\circ} \mathrm{F} .\left(110^{\circ} \mathrm{C}\right)\end{array}$ & Negligible & Negligible & & 0.0 & Negligible \\
\hline $\begin{array}{l}\text { After Heating } \\
\text { at } 1000^{\circ} \mathrm{F} .\left(540^{\circ} \mathrm{C}\right)\end{array}$ & 0.0 to -0.5 & Negligible & & & $0.010-0.3$ \\
\hline at $1500^{\circ} \mathrm{F} \cdot\left(815^{\circ} \mathrm{C}\right)$ & & Negligible & & 0.0 & $0.010-0.3$ \\
\hline at $2000^{\circ} \mathrm{F} .\left(1093^{\circ} \mathrm{C}\right)$ & & & & 0.0 to +0.2 & \\
\hline at $2300^{\circ} \mathrm{F} \cdot\left(1260^{\circ} \mathrm{C}\right)$ & & 0.0 to -1.0 & & & \\
\hline at $2500^{\circ} \mathrm{F} \cdot\left(1370^{\circ} \mathrm{C}\right)$ & & & & & $-1.010-2.7$ \\
\hline $\begin{array}{l}\text { Chemical Analysis: } \\
\text { Silica }\left(\mathrm{SiO}_{2}\right)\end{array}$ & $50.0 \%$ & $71.7 \%$ & & $1.2 \%$ & $5.6 \%$ \\
\hline Alumina $\left(\mathrm{Al}_{2} \mathrm{O}_{3}\right)$ & 22.0 & 17.1 & & 90.6 & 32.8 \\
\hline Titania $\left(\mathrm{TiO}_{2}\right)$ & 1.2 & 0.8 & & 0.3 & \\
\hline Iron Oxide $\left(\mathrm{Fe}_{2} \mathrm{O}_{3}\right)$ & 2.2 & 0.6 & & 04 & 15.5 \\
\hline Lime $(\mathrm{CaO})$ & 20.5 & 9.6 & & 7.2 & 12.5 \\
\hline Magnesia (MgO) & 1.4 & 0.2 & & 0.2 & 12.1 \\
\hline Alkalies $\left(\mathrm{Na}_{2} \mathrm{O}+\mathrm{K}_{2} \mathrm{O}+\mathrm{Li}_{2} \mathrm{O}\right)$ & 2.7 & & & 0.1 & \\
\hline Chrome Oxide $\left(\mathrm{CR}_{2} \mathrm{O}_{3}\right)$ & & & & & 21.5 \\
\hline
\end{tabular}

Application methods. C. Cast; R. Rammed, and T, Trowelled. For Gunning reler 10 Harbison.Walkers' "High Callber Gunning Mix" Brochure.

- Limited Data

All data based on cast specimens. ASTM procedures, where applicable, used to determination of data

All data subject to reasonable deviation and, therefore, should not be used for specification purposes

tNote concerning chrome bearing castables: Process variables may sufficiently alter castable chemistry so as to require solia waste disposai under applicable local, state or federal hazardous wasle laws. 
Harbison-Walker Special Castable Refractories

\begin{tabular}{|c|c|c|c|c|}
\hline Brands & HARCROME' G & CHROMEPAK $\cdot \dagger$ & $\begin{array}{c}\text { FUSIL } \\
\text { Castable } 8201\end{array}$ & $\begin{array}{c}\text { FUSiL } \\
\text { Castable } 840\end{array}$ \\
\hline $\begin{array}{l}\text { Maximum Service } \\
\text { Temperature }{ }^{\circ} \mathrm{F} \text {. }\end{array}$ & 2700 & & 2000 & 2000 \\
\hline $\begin{array}{l}\text { Approximate Amount } \\
\text { Water Required per } 100 \\
(46.26 \mathrm{Kg}) \text { U.S. Gal. }\end{array}$ & $.75 \cdot 1.0$ & $.75 \cdot 1.0$ & $1.75 \cdot 2.0$ & $1.75-2.0$ \\
\hline $\begin{array}{l}\text { Lbs. Dry Mix } \\
\text { Required/cu. ft. }\end{array}$ & 171 & 175 & 110 & 110 \\
\hline Application & C.T & C.R & C & C \\
\hline $\begin{array}{l}\text { Bulk Density, Ibs./cu. ft } \\
\text { After Drying } \\
\text { at } 230^{\circ} \mathrm{F} .\left(110^{\circ} \mathrm{C}\right)\end{array}$ & 179 & & 113 & 117 \\
\hline $\begin{array}{l}\text { MOR, psi } \\
\text { After Drying } \\
\text { at } 230^{\circ} \mathrm{F} .\left(110^{\circ} \mathrm{C}\right)\end{array}$ & $1000-1400$ & $600 \cdot 1000$ & & \\
\hline $\begin{array}{l}\text { After Heating } \\
\text { at } 1000^{\circ} \mathrm{F} \cdot\left(540^{\circ} \mathrm{C} \text {, }\right.\end{array}$ & $1200-1700$ & $350 \cdot 750$ & & \\
\hline at $1500^{\circ} \mathrm{F} \cdot\left(815^{\circ} \mathrm{C}\right)$ & $1200 \cdot 1700$ & $350-750$ & & \\
\hline at $2900^{\circ} \mathrm{F} .\left(1595^{\circ} \mathrm{C}\right)$ & & $750-1100$ & & \\
\hline $\begin{array}{l}\text { Cold Crushing Strength } \\
\text { Atter Drying } \\
\text { at } 230^{\circ} \mathrm{F} .\left(110^{\circ} \mathrm{C}\right)\end{array}$ & $6500-8500$ & $2500-4500$ & $4000 \cdot 7000$ & $3000 \cdot 6000$ \\
\hline $\begin{array}{l}\text { After Heating } \\
\text { at } 1000^{\circ} \mathrm{F} .\left(540^{\circ} \mathrm{C}\right)\end{array}$ & $7000-9000$ & $3000-5000$ & & \\
\hline at $1500^{\circ} \mathrm{F} .\left(815^{\circ} \mathrm{C}\right)$ & $7000-9000$ & $2000-4000$ & & \\
\hline at $2000^{\circ} \mathrm{F} \cdot\left(1093^{\circ} \mathrm{C}\right)$ & & & $3000-5000$ & $2500-5000$ \\
\hline at $2900^{\circ} \mathrm{F}\left(1595^{\circ} \mathrm{C}\right)$ & & $6000-8000$ & & \\
\hline $\begin{array}{l}\text { Permanent Linear Chan } \\
\text { After Drying } \\
\text { at } 230^{\circ} \mathrm{F} .\left(110^{\circ} \mathrm{C}\right)\end{array}$ & Negligible & Negligible & Negligible & Negligible \\
\hline $\begin{array}{l}\text { After Heating } \\
\text { at } 1000^{\circ} \mathrm{F} \cdot\left(540^{\circ} \mathrm{C}\right)\end{array}$ & Negligible & Negligible & & \\
\hline at $1500^{\circ} \mathrm{F} .\left(815^{\circ} \mathrm{C}\right)$ & Negligible & $-0.110-0.3$ & & \\
\hline at $2000^{\circ} \mathrm{F} \cdot\left(1093^{\circ} \mathrm{C}\right)$ & & & $-0.510-1.0$ & $-0.110-0.4$ \\
\hline at $2700^{\circ} \mathrm{F} \cdot\left(1480^{\circ} \mathrm{C}\right)$ & $-1.010-2.3$ & & & \\
\hline at $2900^{\circ} \mathrm{F}\left(1595^{\circ} \mathrm{C}\right)$ & & -0.6 to -1.3 & & \\
\hline $\begin{array}{l}\text { Chemical Analysis: } \\
\text { Silica }\left(\mathrm{SiO}_{2}\right)\end{array}$ & $3.8 \%$ & $8.0 \%$ & $64.8 \%$ & $70.4 \%$ \\
\hline Alumina $\left(\mathrm{Al}_{2} \mathrm{O}_{3}\right)$ & 41.1 & 22.6 & 28.8 & 24.3 \\
\hline Iron Oxide $\left(\mathrm{Fe}_{2} \mathrm{O}_{3}\right)$ & 11.1 & 10.8 & & \\
\hline Lime $(\mathrm{CaO})$ & 43 & 0.6 & 6.4 & 5.3 \\
\hline Magnesıa (MgO) & 14.1 & 33.4 & & \\
\hline Cnrome Oxide $\left(\mathrm{CR}_{2} \mathrm{O}_{3}\right)$ & 25.1 & 24.6 & & \\
\hline
\end{tabular}

Appication methods C. Cast. A. Rammed, and T. Trowelled For Gunn...y refer to Harbison.Waikers' "High Calıber Gunning Mix" Brochure.

Limiseo Data

All data based on cast specimens ASTM procedures. where applicable, used to determination of da.a

All data subject to reasonable deviation and. therefore. should not be used for specification purposes.

- Note concerning chrome bearing castables Process variables may sufficiently alter castable chemistry so as to require solid waste disposal under applicable local state or tederal hazardous waste laws 
Harbison-Walker Vibration Castables Demanding Ultra-High Strengths

\begin{tabular}{|c|c|c|c|c|}
\hline Brands & DESCON" $A 93 / C^{\circ}$ & DESCON $\triangle 58^{\circ}$ & DESCON A94' & DESCON ${ }^{\circ} A B 0^{*}$ \\
\hline $\begin{array}{l}\text { Maximum Service } \\
\text { Temperature }{ }^{\circ} \mathrm{F} \text {. }\end{array}$ & 3300 & 3300 & $\begin{array}{l}\text { Load Bearing Sen } \\
\qquad 2600\end{array}$ & 3200 \\
\hline $\begin{array}{l}\text { Water Required For } \\
\text { Vibration Casting }\end{array}$ & $5.0 \cdot 7.0 \%$ & $4.0 \cdot 6.0 \%$ & $3.5 \cdot 5.0 \%$ & $5.0 \cdot 6.5 \%$ \\
\hline $\begin{array}{l}\text { Dry Weight Required Per } \\
\text { Unit of Volume, pcf }\end{array}$ & 180 & 187 & 186 & 168 \\
\hline $\begin{array}{l}\text { Bulk Density, Ibs./cu. ft. } \\
\text { After Drying } \\
\text { at } 230^{\circ} \mathrm{F} .\left(110^{\circ} \mathrm{C}\right)\end{array}$ & 181 & 188 & 185 & 171 \\
\hline $\begin{array}{l}\text { MOR, psi } \\
\text { After Drying } \\
\text { at } 230^{\circ} \mathrm{F} .\left(110^{\circ} \mathrm{C}\right)\end{array}$ & 1500 & 2000 & 2000 & 1750 \\
\hline $\begin{array}{l}\text { Atter Heating } \\
\text { at } 1500^{\circ} \mathrm{F} .\left(815^{\circ} \mathrm{C}\right)\end{array}$ & 1200 & 2000 & 2300 & 1500 \\
\hline at $3000^{\circ} \mathrm{F} \cdot\left(1650^{\circ} \mathrm{C}\right)$ & 1300 & & 6000 & \\
\hline at $3140^{\circ} \mathrm{F} \cdot\left(1725^{\circ} \mathrm{C}\right)$ & & 1500 & & 2400 \\
\hline $\begin{array}{l}\text { Hot MOR. } \\
\text { at } 2000^{\circ} \mathrm{F} .\left(1093^{\circ} \mathrm{C}\right) \\
\text { at } 2500^{\circ} \mathrm{F} .\left(1370^{\circ} \mathrm{C}\right) \\
\text { at } 2700^{\circ} \mathrm{F} .\left(1480^{\circ} \mathrm{C}\right)\end{array}$ & & & $\begin{array}{l}1540 \\
730\end{array}$ & $\begin{array}{l}2700 \\
410 \\
\end{array}$ \\
\hline $\begin{array}{l}\text { Cold Crushing Strength, psi } \\
\text { Ater Drying } \\
\text { at } 230^{\circ} \mathrm{F} .\left(110^{\circ} \mathrm{C}\right)\end{array}$ & 8000 & 12,000 & 13,000 & 10,000 \\
\hline $\begin{array}{l}\text { After Heating } \\
\text { at } 1500^{\circ} \mathrm{F} .\left(815^{\circ} \mathrm{C}\right)\end{array}$ & 6000 & 10,000 & 12.000 & 9000 \\
\hline at $3000^{\circ} \mathrm{F} \cdot\left(1650^{\circ} \mathrm{C}\right)$ & 8000 & & 15,000 & \\
\hline at $3140^{\circ} \mathrm{F}\left(1725^{\circ} \mathrm{C}\right)$ & & 12,000 & & 10,000 \\
\hline $\begin{array}{l}\text { Permanent Linear Change of } \\
\text { After Heating } \\
\text { at } 1500^{\circ} \mathrm{F} .\left(815^{\circ} \mathrm{C}\right)\end{array}$ & $-0.1 \%$ & $-0.1 \%$ & $-0.2 \%$ & $-0.2 \%$ \\
\hline at $3000^{\circ} \mathrm{F} \cdot\left(1650^{\circ} \mathrm{C}\right)$ & $+0.6 \%$ & & $-1.4 \%$ & \\
\hline at $3140^{\circ} \mathrm{F} \cdot\left(1725^{\circ} \mathrm{C}\right)$ & & $-0.7 \%$ & & $-0.5 \%$ \\
\hline $\begin{array}{l}\text { Chemical Analysis: } \\
\text { Silica }\left(\mathrm{SiO}_{2}\right)\end{array}$ & $0.3 \%$ & $0.1 \%$ & $5.0 \%$ & $11.3 \%$ \\
\hline Alumina $\left(\mathrm{Al}_{2} \mathrm{O}_{3}\right)$ & 92.5 & 97.6 & 93.0 & 82.5 \\
\hline Titania $\left(\mathrm{TiO}_{2}\right)$ & Trace & Trace & 0.1 & 3.2 \\
\hline Iron Oxide $\left(\mathrm{Fe}_{2} \mathrm{O}_{3}\right)$ & 0.2 & 0.2 & 0.2 & 1.1 \\
\hline Lime $(\mathrm{CaO})$ & 1.6 & 1.5 & 1.5 & 1.6 \\
\hline Magnesia (MgO) & 0.1 & Trace & 0.1 & 0.1 \\
\hline Alkalies $\left(\mathrm{Na}_{2} \mathrm{O}+\mathrm{K}_{2} \mathrm{O}+\mathrm{Li}_{2} \mathrm{O}\right)$ & 0.1 & 0.1 & 0.1 & 0.2 \\
\hline Chrome Oxide $\left(\mathrm{CR}_{2} \mathrm{O}_{3}\right)$ & 5.2 & - & - & - \\
\hline
\end{tabular}

Application methods: VC. Vibration Casting using external vibration

- Limited Data

All DESCON brands include H.W's C.CURED System

All data based on cast specimens. ASTM procedures. where applicable. used lor determination of data All data subject to reasonable deviation and ineretore

should nol be used for specification purposes 


\begin{tabular}{|c|c|c|c|c|}
\hline Brands & DESCON'A7O/CU* & DESCON 'A6O" & DESCON $\mathrm{F}^{4} 5^{\circ}$ & DESCON ${ }^{\circ}$ S97* \\
\hline $\begin{array}{l}\text { Maximum Service } \\
\text { Temperature }{ }^{\circ} \mathrm{F} \text {. }\end{array}$ & 3100 & 3100 & 2800 & $\begin{array}{l}3000 \text { (Continuous Service) } \\
2000 \text { (Intermittent Service) }\end{array}$ \\
\hline $\begin{array}{l}\text { Water Required For } \\
\text { Vibration Casting }\end{array}$ & $6.5 \cdot 7.5 \%$ & $4.5-6.0 \%$ & $5.0 \cdot 6.0 \%$ & $7.0 \cdot 9.5 \%$ \\
\hline $\begin{array}{l}\text { Dry Weight Required Per } \\
\text { Unit of Volume, pef }\end{array}$ & 151 & 145 & 139 & 109 \\
\hline $\begin{array}{l}\text { Bulk Density, Ibs./cu. } \mathrm{tt} \text {. } \\
\text { After Drying } \\
\text { at } 230^{\circ} \mathrm{F} .\left(110^{\circ} \mathrm{C}\right)\end{array}$ & 164 & 150 & 140 & 116 \\
\hline $\begin{array}{l}\text { MOR, psi } \\
\text { After Drying } \\
\text { at } 230^{\circ} \mathrm{F} .\left(110^{\circ} \mathrm{C}\right)\end{array}$ & 1600 & 1350 & 1000 & 1200 \\
\hline $\begin{array}{l}\text { After Heating } \\
\text { at } 1500^{\circ} \mathrm{F} .\left(815^{\circ} \mathrm{C}\right)\end{array}$ & 1000 & 2400 & 1200 & $\cdot$ \\
\hline ai $2550^{\circ} \mathrm{F} \cdot\left(1397^{\circ} \mathrm{C}\right)$ & 950 & & & \\
\hline at $2700^{\circ} \mathrm{F} .\left(1480^{\circ} \mathrm{C}\right)$ & & & 900 & 650 \\
\hline at $3000^{\circ} \mathrm{F} .\left(1650^{\circ} \mathrm{C}\right)$ & & 820 & & \\
\hline $\begin{array}{l}\text { Cold Crushing Strength, psi } \\
\text { After Drying } \\
\text { at } 230^{\circ} \mathrm{F} .\left(110^{\circ} \mathrm{C}\right)\end{array}$ & 7200 & 10,000 & 7000 & 6500 \\
\hline $\begin{array}{l}\text { After Heating } \\
\text { at } 1500^{\circ} \mathrm{F} \cdot\left(815^{\circ} \mathrm{C}\right)\end{array}$ & 7000 & 10,500 & 10,000 & \\
\hline at $2550^{\circ} \mathrm{F} \cdot\left(1397^{\circ} \mathrm{C}\right)$ & 5440 & & & \\
\hline at $2700^{\circ} \mathrm{F} .\left(1480^{\circ} \mathrm{C}\right)$ & & & 7500 & 9800 \\
\hline at $3000^{\circ} \mathrm{F} \cdot\left(1650^{\circ} \mathrm{C}\right)$ & & 8500 & & \\
\hline $\begin{array}{l}\text { Permanent Linear Change } \% \\
\text { After' Heating } \\
\text { at } 1500^{\circ} \mathrm{F} \cdot\left(815^{\circ} \mathrm{C}\right)\end{array}$ & $+0.1 \%$ & $-0.3 \%$ & $-0.3 \%$ & \\
\hline at $2550^{\circ} \mathrm{F} .\left(1397^{\circ} \mathrm{C}\right)$ & $+0.5 \%$ & & & \\
\hline at $2700^{\circ} \mathrm{F} .\left(1480^{\circ} \mathrm{C}\right)$ & & & $+1.1 \%$ & $-0.2 \%$ \\
\hline ai $3000^{\circ} \mathrm{F} .\left(1650^{\circ} \mathrm{C}\right)$ & & $+0.5 \%$ & & \\
\hline $\begin{array}{l}\text { Chemical Analysis: } \\
\text { Silica }\left(\mathrm{SiO}_{2}\right)\end{array}$ & $14.5 \%$ & $37.8 \%$ & $50.0 \%$ & $96.3 \%$ \\
\hline Alumina $\left(\mathrm{Al}_{2} \mathrm{O}_{3}\right)$ & 70.7 & 57.0 & 44.2 & 0.5 \\
\hline Titania $\left(\mathrm{TiO}_{2}\right)$ & 2.2 & 2.3 & 2.1 & Trace \\
\hline Iron Oxide $\left(\mathrm{Fe}_{2} \mathrm{O}_{3}\right)$ & 1.1 & 1.0 & 0.9 & 0.1 \\
\hline Lime $(\mathrm{CaO})$ & 1.5 & 1.6 & 1.8 & 3.0 \\
\hline Magnesia (MgO) & 0.1 & 0.1 & 0.3 & Trace \\
\hline Alkalies $\left(\mathrm{Na}_{2} \mathrm{O}+\mathrm{K}_{2} \mathrm{O}+\mathrm{Li}_{2} \mathrm{O}\right)$ & 0.1 & 0.2 & 0.7 & 0.1 \\
\hline \multicolumn{5}{|l|}{ Chrome Oxide $\left(\mathrm{CR}_{2} \mathrm{O}_{3}\right)$} \\
\hline Penetration Inhibitor & 10.0 & & & \\
\hline
\end{tabular}

Application methods: VC. Vibration Casting using external vibration.

- Limited Data

All DESCON brands include H-W'S C.CURED System

All data based on cast specimens. ASTM procedures, where applicable, used for determination of data. All data subject to reasonable deviation and, therefore, should not be used for specification purposes. 
Stainless Steel Fibers Add Strength and Long Life to Refractory Linings.

Work of Fracture Testing Shows Benefits of Stainless Steel Fiber Additions.

All Harbison-Walker castables and gunning mixes can be installed with stainless steel fiber additions. The best demonstration of the benefits strinless steel fibers impart to monolithic refractories is provided by work of fracture testing.

Harbison-Walker pioneered largescale work of fracture testing programs for refractories because this test most accurately measures crack propagation, the major cause of refractory failure in monoliths under thermal cycling service conditions similar to ash hoppers.

The procedure for work of fracture testing is similar to modulus of rupture testing, although not only refractory strength but also crack resistance and holding power after fracture are measured. In the test, a sample of refractory with a notch cut in the underside is placed in tension. Pressure on the sample continues until it fails and the pressure exerted as well as the time expired is noted. Pressure is then continued after failure until the sample breaks apart completely,

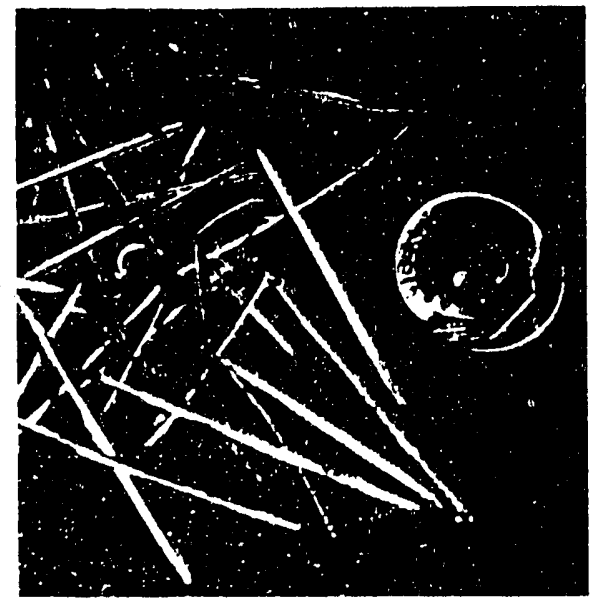

Fig. 29 Addition of stainless steel fibers to castable and gunned refractories increases strength and service life. and the force and time required are noted.

Figure 30 shows the typical results of work of fracture testing on samples of monolithic refractory with and without stainless steel additions. As the graph illustrates, fiber additions not only increase the ultimate strength of the refractory, more importantly they yield dramatic increases in crack resistance and holding power after cracking. Testing with various types of refractories has shown that all monoliths tested showed improvement in crack resistance anci holding power, although the improvement varied accurding to density, cement content, and aggregate size of the material. Stainless steel fiber additions were also shown to increase $\mathrm{K}$ factors very little since the steel fiber is dispersed in the refractory mass. Tests have shown that thermal conductivity of monoliths with stainless steel fiber additions should increase no more than 5 percent.

A typical fiber for addition to gunning mixes and castables is one inch long and .015 to .020-inch in diameter. Fibers of this size should pass through standard 1.25-inch diameter gunning nozzles with no obstruction. Fibers may be ordered separately and mixed with the refractory prior to pouring castable or charging the emplacement gun. And, although stainless steel fibers produce significant performance benefits when added to castables and gunning mixes, they do not affect the pouring or gunning properties of the mixes and present no rebound problems.

The grade of fiber used for refractory reinforcement will be dictated by the operating conditions to which it will be subjected. If the temperature of the majority of the refractory lining is below $1800^{\circ} \mathrm{F}$, Type 304 stainless steel fibers should serve well. At soaking temperatures, where the majority of the lining is approximately $2000^{\circ} \mathrm{F}$ Type 310 fibers can give satisfactory performance. However, ash hoppers some times present acid conditions that may require a special grade of stainless steel fiber. Please consult a Harbison-Walker representative or the fiber manufacturer for details.

Fig. 30 Work of fracture test results for monolithic refractory samples with and without stainless steel fiber additions.

$\begin{aligned} & \text { Standard } \\ & \text { Sample } \\ & \text { (work or en fracture). }\end{aligned}$

Fiber Additional work necessary to crack and fracture fiber reinforced Sample

Fiber Sample WلW (extra holding power).

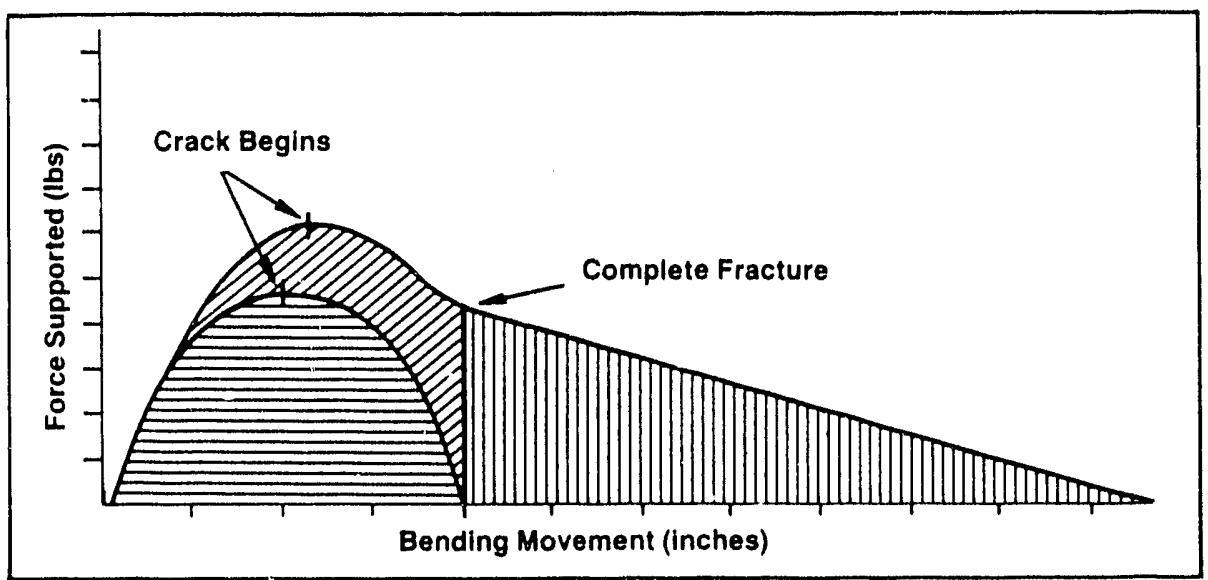




\section{The C-CURED ${ }^{\text {TM }}$ System Approach}

$H$-W's advanced-technology system utilizes a specially sized non-metallic addition that shrinks and burns at very low temperatures, thus producing minute, non-continuous passageways in the refractory. The unique shrinkage characteristics of the C-CURED ${ }^{\text {TM }}$ additive allows water release at critical temperatures during the heatup. The increase in permeability reduces the danger of steam spalling and allows faster heatup rates by means of a fast, evenly distributed release of both the mechanically and chemically combined water. And because the additive in the C-CURED System is considerably smaller than in any other commercially available system, the passageways have little or no affect on properties such as strength and metal handling.

The H.W C-CURED System is the first techology that produces steam passageways of the right size at the right time.

When C-CURED castables or gunning mixes are used, initial heatup rates can be accelerated. However, as with brick and plastiv linings, the initial heatup rates of C-CURED linings must be examined individually. Parameters such as furnace size, lining thickness, material quality, expansion and temperature gradient vary with every furnace and affect the heatup rate. Based on laboratory heatup tests, microscopic analysis of the C-CURED material, and actual field installations, a heatup schedule can be formulated that maximizes energy savings, material properties, and safety. Please discuss your specific situation with a HarbisonWalker representative.

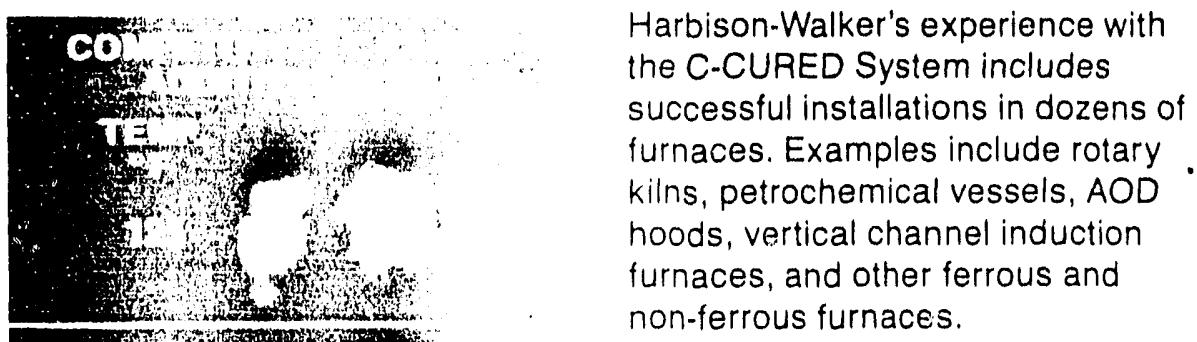

The C-CURED System is available in most H.W castables arid gun mixes. For actual physical properties of H-W C-CURED material, consult the C-CURED brochure or call your nearest Harbison-Walker office.

Note of Caution: The C-CURED System offers great improvements over conventional gunning mixes and castables. However, as with all castables and gun mixes with nonmetallic additions, the danger of steam spalling still exists.

Fig. 31 Laboratory testing shows that the C.CURED TM refractory system shrinks as steam evolves from the refractory lining, well below temperatures of shrinkage of other additives. 
NORTH AMERICAN REFRACTORIES 


\section{CUSTOMER LIST}

\section{PROJECT LIST WHERE NARCO REFRACTORY PRODUCTS HAVE BEEN INSTALLED}

1. Hyperion Energy Recovery System Sludge Combustion Facility, Eement 124 EPA Project No. C-06-2417-410

City of Los Angeles. Califomia

2. CAL-MAT, InC.

Califomia Pordand Cement Division Cogeneration System for Cemem Kiln Colton, Califomia

3. Garrett Air Research Corporation Combustion Power Corporation Clrculating Fluidized Bed Incinerator Torrance, Califomia

*4. lone Energy Project Lurgi Corporation Circulating Fuidized Bed Incinerator Ione, California

5. Colorado Ute Electric

Pyropower Corporation

Circulating Fluidized Bed incinerator Nucla, Colorado

6. Port of Stockton

Combustion Power Corporation Circulating Fluidized Bed Incinerator Stockton, Califomia

7. Biogen Project

Combustion Power Corporation Circulating Fluidized Bed Incinerator Ivanpah, California

8. Shasta-Signal Power

Zum Industries

Anderson, Califomia

* S. Scot Paper Company

Lurgi Corporation

Circulating Fuidized Bed Unit

Chester, Pennsylvania
*10. Ultrasystems Inc. Lurgi Corporation Clrculating Fiuidized Bed Fresno, Califomia

11. Union Oil

Rodeo, Califomia

12. Koppers Company, Inc. Oroville, Califormia

13. Dinuba Energy Inc. Dinuta, California

14. Martel Cogeneration Ltd.

15. Pacific Lighting Energy Oroville, Califomia

16. Ultrapower III Blue Lake

17. Sierra Pacific Inc. Susanville, Califomia

18. Collins Pine Lumber Chester, California

-19. Ultrasystems Inc. Combustion Engineering Circulating Fluidized Bed Rocklin, Califomia

\#20. Ultrasystems Ine. Combustion Engineering Circulating Fluidized Bed Mt Poso, Califomia

\#21. Ultrasystems Inc. Combustion Engineering Circulating Fuidized Bed Bakerstield. Califomia

- Denotes units that have NIKE 50 AR installed in the cyclones.

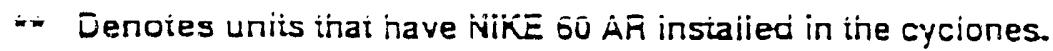


NARCO PRODUCTS FOR THE POWER GENERATION INDUSTRY

\begin{tabular}{lll}
\hline Product & Recommended Applications & Advantages \\
\hline NIKE 60 AR & $\begin{array}{l}\text { Recycle cyclones, inlet duct } \\
\text { walls and floor, loop seal. }\end{array}$ & $\begin{array}{l}\text { Exhibits both excellent } \\
\text { thermal shock resistance } \\
\text { and abrasion resistance. }\end{array}$ \\
\hline NARCO 68 & $\begin{array}{l}\text { Less severe areas of cyclone } \\
\text { such as the cone. }\end{array}$ & $\begin{array}{l}\text { Excellent thermal shock } \\
\text { shock resistance. }\end{array}$ \\
\hline MOHAWK BF & $\begin{array}{l}\text { Loop seal, areas that are } \\
\text { highly abrasive. }\end{array}$ & $\begin{array}{l}\text { High fired super-di.ty brich } \\
\text { which offers excellent } \\
\text { abrasion resistance. }\end{array}$ \\
\hline GUNCRETE & $\begin{array}{l}\text { Monolithic gun mix for } \\
\text { combustion chambers and } \\
\text { cyclone walls and roofs. }\end{array}$ & $\begin{array}{l}\text { Good gunability, abrasion } \\
\text { resistant with low iron } \\
\text { content. }\end{array}$
\end{tabular}

NARMUL $P \quad \begin{aligned} & \text { Burner throats, feed chutes, } \\ & \text { bull nose of cyclone. }\end{aligned}$

Excellent strength and abrasion resistance.

\begin{tabular}{lll}
\hline ALCHROME 85 P & $\begin{array}{l}\text { Target walls of cyclone, high } \\
\text { impact areas, refractory shelf } \\
\text { in combustor. }\end{array}$ & $\begin{array}{l}\text { Highly resistant to slag } \\
\text { attack, tough and abrasion } \\
\text { resistant. }\end{array}$ \\
\hline NARPHOS 85 P & $\begin{array}{l}\text { Combustion chamber work- } \\
\text { ing lining, patch material for } \\
\text { cyclones. }\end{array}$ & $\begin{array}{l}\text { Good abrasion resistant } \\
\text { phosphate-bonded mate- } \\
\text { rial. }\end{array}$ \\
\hline LO-CAST 50 HS & $\begin{array}{l}\text { Inlet floor, burner throats, } \\
\text { manway doors. }\end{array}$ & $\begin{array}{l}\text { Low moisture castable } \\
\text { which offers very high } \\
\text { strengths. }\end{array}$ \\
\hline $\begin{array}{l}\text { NARCOSET } \\
\text { TENAX }\end{array}$ & $\begin{array}{l}\text { Mortars used with all super- } \\
\text { duty brick in cyclones. }\end{array}$ & $\begin{array}{l}\text { Excellent workability for } \\
\text { tight joints. }\end{array}$ \\
\hline
\end{tabular}


NARCO PRODUCTS FOR THE POWER GENERATION INDUSTRY

\begin{tabular}{lll}
\hline Product & Recommended Applicatlons & Advantages \\
\hline NIKE 60 AR & $\begin{array}{l}\text { Recycle cyclones, inlet duct } \\
\text { walls and floor, loop seal. }\end{array}$ & $\begin{array}{l}\text { Exhibits both excellent } \\
\text { thermal shock resistance } \\
\text { and abrasion resistance. }\end{array}$ \\
\hline
\end{tabular}

\begin{tabular}{|c|c|c|}
\hline $\begin{array}{l}\text { NARCOGUN } \\
\text { AR-50 }\end{array}$ & $\begin{array}{l}\text { Cycione inlet ducts and roofs, } \\
\text { walls and roof of combustors. } \\
\text { Fluid bed heat exchanger walls } \\
\text { and roof. }\end{array}$ & $\begin{array}{l}\text { Excellent abrasion resist- } \\
\text { ance at } 1500-18000 \mathrm{~F} \text {. } \\
\text { Low rebound with good } \\
\text { gunability. }\end{array}$ \\
\hline GUNCRETE & $\begin{array}{l}\text { Monolithic gun mix for } \\
\text { combustion chambers and } \\
\text { cyclone walls and roofs. } \\
\text { FBHE walls and roof. }\end{array}$ & $\begin{array}{l}\text { Good gunability, abrasion } \\
\text { resistant with low iron } \\
\text { content. }\end{array}$ \\
\hline NARMULP & $\begin{array}{l}\text { Burner throats, feed chutes, } \\
\text { bull nose of cyclone. }\end{array}$ & $\begin{array}{l}\text { Excellent strength and } \\
\text { abrasion resistance. }\end{array}$ \\
\hline ALCHROME 85 P & $\begin{array}{l}\text { Target walls of cyclone, high } \\
\text { impact areas, refractory shelf } \\
\text { in combustor. }\end{array}$ & $\begin{array}{l}\text { Highly resistant to slag } \\
\text { attack, tough and abrasion } \\
\text { resistant. }\end{array}$ \\
\hline NARPHOS 85 P & $\begin{array}{l}\text { Combustion chamber work- } \\
\text { ing lining, patch material for } \\
\text { cyclones. }\end{array}$ & $\begin{array}{l}\text { Good abrasion resistant } \\
\text { phosphate-bonded mate- } \\
\text { rial. }\end{array}$ \\
\hline LO-CAST 50 HS & $\begin{array}{l}\text { Inlet floor, burner throats, } \\
\text { manway doors. }\end{array}$ & $\begin{array}{l}\text { Low moisture castable } \\
\text { which ofiers very high } \\
\text { strengths. }\end{array}$ \\
\hline $\begin{array}{l}\text { NARCOSET } \\
\text { TENAX } \\
\end{array}$ & $\begin{array}{l}\text { Mortars used with all super- } \\
\text { duty brick in cyclones. }\end{array}$ & $\begin{array}{l}\text { Excellent workability for } \\
\text { tight joints. }\end{array}$ \\
\hline $\begin{array}{l}\text { HPV-50 } \\
\text { DURAKAST } 56\end{array}$ & $\begin{array}{l}\text { Cyclone inlet floors, seal pot } \\
\text { foors, combustor grate, FBHE } \\
\text { grate. }\end{array}$ & $\begin{array}{l}\text { Ultra-high strengths up to } \\
18000 \mathrm{~F} \text {. Excellent } \\
\text { abrasion resistance, } \\
\text { extreme resistance to } \\
\text { erosion by hot abrasive } \\
\text { gases. }\end{array}$ \\
\hline
\end{tabular}
AEROCAST L
Cyclone inlet duct floors, seal pot floors, FBHE floor, cyclone domed outlet duct floors.

Heat saving product used for working lining or backup. High refractoriness, good high temperature strengths and negligible shrinkage.

Very abrasion resistant, fused silica makes HPV-SX resistant to thermal shock. High strength and erosion resistance at $1800^{\circ} \mathrm{F}$.

Lightweight hydraulic setting gun mix offering great strengths up to operating temperatures of $2000^{\circ} \mathrm{F}$. 


\section{HPV-SX}

\section{Low Moisture Castable}

\section{CHARACTERISTICS}

HPV-SX exhibits very high strengths at temperatures up to $1800^{\circ} \mathrm{F}$. This strength makes HPV-SX very resistant to erosion by hot gases and also mechanical abuse. Due to its low density and fused silica aggregate, HPV-SX has a very low thermal conductivity. The low porosity and fused silica present in HPV-SX makes it very resistant to damage by thermal shock. HPV-SX was designed to be cast vibrated with a very low water content. Thus, it has a very low drying shrinkage and less sintering shrinkage in service.

\section{APPLICATION AREAS}

(A) Seal pot and seal pots inlet and outlet duct hot face lining.

(B) FBHE's inlet ducts.

\section{TEST DATA}

Method of Installation

Gunning

Maximum Service Temperature, ${ }^{\circ} \mathrm{F}$

2600

Bulk Density, pcf

Fired to $230^{\circ} \mathrm{F}$

Fired to $1500^{\circ} \mathrm{F}$

Cold Crushing Strength, psi

Fired to $230^{\circ} \mathrm{F}$

Fired to $1500^{\circ} \mathrm{F}$

8500

Fired to $2000^{\circ} \mathrm{F}$

7500

Abrasion Resistance, cc

5900

Thermal Conductivity - Btu-in.

@ 500 $\mathrm{F}\left(260^{\circ} \mathrm{C}\right)$

@ $1000^{\circ} \mathrm{F}\left(538^{\circ} \mathrm{C}\right)$

@ 1500 $\mathrm{F}\left(816^{\circ} \mathrm{C}\right)$

6.5

7.2

\section{CHEMICAL COMPOSITION, \%}

$\begin{array}{lr}\mathrm{Al}_{2} \mathrm{O}_{3} & 27.5 \\ \mathrm{SiO}_{2} & 66.8 \\ \mathrm{Fe}_{2} \mathrm{O}_{3} & 0.3 \\ \mathrm{TiO}_{2} & 0.4 \\ \mathrm{CaO} & 4.7 \\ \mathrm{MgO} & 0.1\end{array}$




\section{Low Moisture Castable}

\section{CHARACTERISTICS}

HPV-50 offers ultra-high strength up to $1800^{\circ} \mathrm{F}$ which makes it extreinely resistant to erosion by hot abrasive gases and mechanical abuse.

Due to the high density and low porosity, HPV-50 exhibits very good abrasion resistance. HPV-50 is also volume stable due to the low water content required in comparison to a conventional castable.

\section{APPLICATION AREAS}

(A) Cyclone inlet duct floors.

(B) Floors of dorined cyclone outlet ducts.

(C) Seal pot floors.

(D) Combustor grate.

(E) Duct - FBHE to combustor flours.

(F) FBHE grate.

\section{TEST DATA}

Method of Installation

Maximum Service Temperature, ${ }^{\circ} \mathrm{F} \quad 3000$

Bulk Density, pcf

Fired to $230^{\circ} \mathrm{F}$

Fired to $1500^{\circ} \mathrm{F}$

Cold Crushing Strength, psi

Fired to $230^{\circ} \mathrm{F}$

Fired to $1472^{\circ} \mathrm{F}$

9000

8000

Abrasion Resistance, cc

CHEMICAL COMPOSITION, Wt. \%

$\begin{array}{ll}\mathrm{Al}_{2} \mathrm{O}_{3} & 50 \\ \mathrm{SiO}_{2} & 46 \\ \mathrm{CaO} & 2.5\end{array}$




\section{NARCOGUN AR-50}

\section{Abrasion Resistant Gun Mix}

\section{CHARACTERISTICS}

NARCOGUN AR-50 offers excellent abrasion resistance at operating temperatures between $1500^{\circ} \mathrm{F}-1800^{\circ} \mathrm{F}$. Due to its excellent gunability, NARCOGUN AR-50 is easily applied with low rebound loss.

\section{APPLICATION AREAS}

(A) Cyclone inlet duct roofs and cyclone roofs.

(B) Cyclone domed outlet duct walls and roofs.

(C) FBHE solids return ducts, walls and roof to combustor.

(D) FBHE walls and roof.

\section{TEST DATA}

Method of Installation

Maximum Service Temperature, ${ }^{\circ} \mathrm{F}$

Bulk Density, pcf

Fired to $230^{\circ} \mathrm{F}$

Fired to $1500^{\circ} \mathrm{F}$

Cold Crushing Strength, psi

Fired to $230^{\circ} \mathrm{F}$

Fired to $1500^{\circ} \mathrm{F}$

Abrasion Resistance, cc

Thermal Conductivity - Btu-in.

$$
\text { F } \times h_{i} \times t^{2}
$$

@752 ${ }^{\circ} \mathrm{F}\left(400^{\circ} \mathrm{C}\right)$

@ $1112^{\circ} \mathrm{F}\left(600^{\circ} \mathrm{C}\right)$

@ $1472^{\circ} \mathrm{F}\left(800^{\circ} \mathrm{C}\right)$

CHEMICAL COMPOSITION, Wt. \%

$\mathrm{Al}_{2} \mathrm{O}_{3}$

$\mathrm{Fe}_{2} \mathrm{O}_{3}$

$\mathrm{Na}_{2} \mathrm{O}$

$\mathrm{K}_{2} \mathrm{O}$

$\mathrm{CaO}$
Gunning

2600

135

126

8800

5300

$230 / 6$

$1500 / 11$
6.1

6.5

7.2

49

37

0.6

0.1

0.2

6.3 


\section{LITECRETE HS 2065 GUN}

\section{Insulating Gun Mix}

\section{CHARACTERISTICS}

LITECRETE HS 2065 GUN is a lightweight hydraulic-setting gun mix which offers extra strength without decreasing its insulating value. This material provides a structurally sound heat barrier and can be used at operating temperatures up to $2000^{\circ} \mathrm{F}$.

\section{APPLICATION AREAS}

(A) Cyclone inlet duct and cyclone roof.

(B) Cyclone domed outlet ducts.

(C) Seal pots and connective duct-work.

(D) FBHE connective duct-work.

(E) FBHE.

\section{TEST DATA}

Method of Installation

Maximum Service Temperature, ${ }^{\circ} \mathrm{F}$

2000

Bulk Density, pcf

Fired to $2300^{\circ} \mathrm{F}$

Fired to $1520^{\circ} \mathrm{F}$

Cold Crushing Strength, psi

Fired to $230^{\circ} \mathrm{F}$

Fired to $1112^{\circ} \mathrm{F}$

Thermal Conductivity - Btu-in.
@ $392^{\circ} \mathrm{F}\left(200^{\circ} \mathrm{C}\right)$
@ $752^{\circ} \mathrm{F}\left(400^{\circ} \mathrm{C}\right)$
1.7
@ $1112^{\circ} \mathrm{F}\left(800^{\circ} \mathrm{C}\right)$
1.8
@ $1472^{\circ} \mathrm{F}\left(800^{\circ} \mathrm{C}\right)$
2.0
2.2

\section{CHEMICAL COMPOSITION, Wt. \%}

$\mathrm{Al}_{2} \mathrm{O}_{3}$

$\mathrm{SiO}_{2}$

$\mathrm{CaO}$ 


\section{AEROCAST L}

\section{Insulating Castable}

\section{CHARACTERISTICS}

AEROCAST $L$ combines good refractory qualities with heat-saving insulating values. AEROCAST $L$ can be used as a back-up or as a working lining exposed to furnace atmospheres. This hydraulic setting castable offers high refractoriness while providing a strong cold set, good high temperature strength, negligible shrinkage and low thermal conductivity. AEROCAST $L$ is also not affected by cyclical furnace operation and is free from rehydration.

\section{APPLICATION AREAS}
(A) Cyclone inlet duct floors.
(B) Seal pot floors.
(C) FBHE floor.
(D) Cyclone domed outlet duct floors.

\section{TEST DATA}

Method of Installation

Maximum Service Temperature, OF 2000

Bulk Density, pcf

Fired to $230^{\circ} \mathrm{F}$

Fired to $1200^{\circ} \mathrm{F}$

Thermal Conductivity - Btu-in. $\frac{\sigma_{F} \times h r}{x+t^{2}}$

@ $392^{\circ} \mathrm{F}\left(200^{\circ} \mathrm{C}\right)$

@752. $\mathrm{F}\left(400^{\circ} \mathrm{C}\right)$

@1112 $\mathrm{F}\left(800^{\circ} \mathrm{C}\right)$

@ $1472^{\circ} \mathrm{F}\left(800^{\circ} \mathrm{C}\right)$

CHEMICAL COMPOSITION, Wt. \%

$\mathrm{Al}_{2} \mathrm{O}_{3}$ 
NORTON 
NORTON CRYSTOLON SILICON CARBIDE MONOLITHIC REFRACTORY OR NORTON CRYSTON SILICON CARBIDE SHAPES

Operational

Date
Number

Facility of Boilers
Capacity (PPH)

\section{Boiler Supplier}

Material

\section{B \& W/Ultrasystems}

1986 Jonesboro, ME

1986 West Enfield, ME

\section{Energy Factors}

1986 Feather River Project Marysville, CA

164,000

Babcock \& Wilcox

LC904

Archer Daniels Midland

1987 Decater, IL

1988 Ceder Rapids, IA

5

3

Constellation Investments/

Ultrapower/CE

1987 Fresno, CA

1989 Rocklin, CA

1989 Bakersfield, CA

Wheelabrator

1988 Frackville, PA

1

425,000

477,000

220,000

220,000

220,000

C-E Lurgi

C-E Lurgi

C-E Lurgi
LC9O4

LC9O4

Northeastern Power

1989 Schuylkill Co., PA

1

485,000

C-E Lurgi

CN183

Schuylkill Energy Resource

1990 Mańanoy City, PA

1

825,000

C-E Lurgi

CN183

AES-Thames.

1989 Montville, CT

2

672,000

C-E Lurgi

$\mathrm{CNIB3}$ 
Operationa 1

Date
Number

Facility of Boilers
Capacity (PPH)

Boiler Supplier Materia

Westwood Eneray Properties

1987 Joliett, PA

1

271,000

C-E Lurgi

LC904

+ CN1E:

Bechtel/Pyropower Cogen.

1989 Bakersfield, CA

1

500,000

Pyropower

LC904

Air Products \& Chemical

1988 Stockton, CA

1

500,000

Pyropower

LC904

Ione Eneroy

1989 Ione, CA

1

146,000

C-E Lurgi

LC9O4 + CN1E:

March 1989 


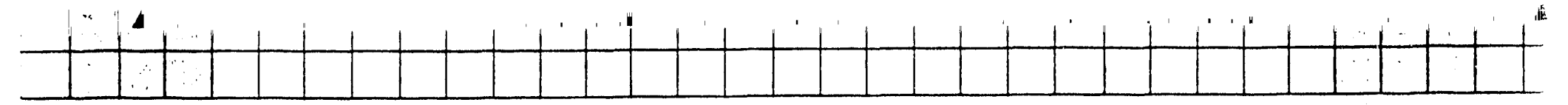

\section{INSTALLATION \& STARTUP PROCEDURES}

\section{FQR GUNNING REFRACTORIES}

\section{INTRODUCTION}

Norton Company's Gunning Mixes have been designed to assure that not only maximum refractory performance is attained but that rebound is minimized. In order that this is achieved, proper installation and curing techniques must be followed. Dutlined in the following are specific recommendations relating to procedures and equipment that will more easily allow the efficient attaimment of a good installation.

\section{PREWETTING}

Dbviously water controls the stickiness of a gunning mix and stickiness retards rebound which maximizes density. If water is only added near the nozzle end, it has minimum time to penetrate the fast flowing stream of dry refractory and properly wet it. Therefore, it is strongly recommended that water be mixed with the cement in a paddle type mixer before gunning is started. The amount added, obviously must not affect the mix's ability to flow through the gunning equipment and hoses. Generally this will be approximately $0.5 \%$ by weight, however it can be more precisely determined on site by squeezing a handful. When the correct maximum amount is added, the handful will form a ball which will easily break up into a granular form when finger pressure is applied. Unfortunately this maximum amount can not always be used. Depending on hose diameter, length, number of bends, etc. clogging could occur and then the amount of water added must be reduced. Prewetted gunning mix must not be allowed to dry out before gunning as its bond ingredients will harden, this is particularly true of hydraulically bonded products.

In order to obtain the highest density and minimum rebound, predampening to the maximum amount is required. In addition using a wet mix will eliminate the discharge of static electricity to the gun operator. 


\section{EQUIPMENT}

Gun Machine

Although virtually all types of gunning equipment could be utilized, Norton Co. strongly recommends those that utilize a rotating feed wheel under a hopper as they provide a much more even and steady material flow. This makes accurate water control at the nozzle easier and results in better control of density and rebound. It has been found that nozzle size should be no larger than 1". The gun should be equipped with working pressure gauges and valves to individually control air pressure to the drive motor and material feed connections.

\section{Air Compressor}

As hose lengths are usually quite long, it is advantageous to have a compressor capable of delivering air at approximately 500 cubic feet per minute at 90-100 psi to insure clog free even refractory delivery. The piping and/or hoses from the cumpressor to the gun should be the same size or larger than the material delivery hose in order to assure that enough air is available. Separate air hoses should be run from the compressor to the air motor drive and material feed connections.

The air should be free of oil and excess moisture. Oil will affect the refractories bonding and water could cause flow/clogging problems. Air stould be checked for oil content by bubbling it into a container of water. A slick on the water surface will be noted if oil is present.

water Delivery

Water pressure must exceed air pressure so that it is properly distributed into the refractory stream. Obviously both pressure and flow must be uniform and therefore a water pump is often advantageous.

\section{Mixer.}

A paddle type mixer is recommended for uniform prewetting. A backup mixer is good insurance against installation delays.

\section{Communication Equipment}

Normally the gun is located some distance from the nozzle man and direct communication is impossible, therefore a radio or telephone headset system of some type is required in order that proper coordination is maintained during installation. 


\section{PREPARATION}

Prior to starting actual gunning, equipment should be checked out. Hoses should have no kinks or tight bends that would retard refractory flow. No fittings in pipe or hose should be a smaller diameter in air, material flow, or water lines. Pressures and flows should be measured to ascertain they are correct. The staging used must allow unobstructed access. Cross bracing, as typically used with "ladder" type staging can be a hindrance and therefore "pipe" staging is usually preferred if not required.

Staging or some type of platform should be erected and positioned so that the nozzle operator can maintain a distance of approximately four feet at right angles to the surface to be gunned.

The surface being gunned should be clean, sanoblasted to remove most rust and any scale. It should also be dry and free of oil. Finally a system should be established to assure that prewetting (mixing) will keep up with refractory usage. Actually mixing should stay far enough ahead of gunning requirements so that proper moisture levels can be easily monitored and maintained.

To enhance clean up of rebound plastic sheets or fabric tarpaulin should be laid down.

\section{INSTALLATION}

There are several major objectives to be pursued and achieved

Obtain proper maximum density

Maintain minimum/maximum thickness control

Obtain a reasonably smooth surface

Minimize rebound

Water control at the nozzle is absolutely critical to all of the above. The amount of water and its distribution is what must be maintained. Even distribution is aided by the use of a 18"-24" section of hose between the water ring and the nozzle as it lengthens mixing time. Using the recommended 1 " maximum I.D. nozzle and running the feed motor on the gun at a moderately slow speed slows down refractory delivery and makes water control easier. It also aids thickness and surface control. If the feed motor speed is too slow, it will not rotate smoothly and delivery will be pulsing and erratic. Air pressure to the material feed hose should be controlled (typically 35-40 psig) to minimize rebound.

$$
-3-
$$


When correctly applied, the refractory surface will exhibit a smooth, slightly wet sheen appearance. Slumping is the result of entirely too much water and requires removal and reapplication as the refractory' density has been affected. Maintaining a distance of approximately 4 feet from the nozzle to the tube surface and maintaining the gun at a $90^{\circ}$ angle is the best procedure. In order to prevent laminations, the surface must not be allowed to dry out between passes, therefore it is best not to work on an area of more than 50 square feet.

In order to eliminate gunning over fallen rebound, it is best to start at the bottom of walls and work up. Rebound will be greatest on the first pass as it is more difficult to bond to the walls than refractory.

Ideally, once applied, the gunned refractory should not be disturbed. However, when a very smooth or contoured surface is required, some surface adjustment may be necessary. A curry comb is the best tool to remove excess thickness as it leaves an open texture. Trowels and/or floats tend to close up surface porosity making water removal more difficult during the dryout cycle. Trowels should be used only when a very smooth surface is required. Overspraying a thin veneer after trimming back is acceptable but must be done before any setting occurs. This is usually no problem with phosphate bonded refractory, but must be done quickly (within 15 minutes) with cement (i.e., calcium aluminate) bonded refractories.

\section{REBOUND}

Rebound is mainly composed of coarse particles. The properties of the refractory rely on proper distribution of particle sizing therefore if rebound is reused the properties (strength, density, thermal conductivity, etc.,) will be adversely affected. Rebound cannot therefore be requnned directly or reblended into new qun mix.

Once installed and before sufficient heat has been introduced to eliminate all moisture from the Norton Gunning mixes, they must not be allowed to be frozen. Remember that water expands when it freezes and this will at the least weaken the soundness of the lining and could actually cause refractory to spall off the walls. 


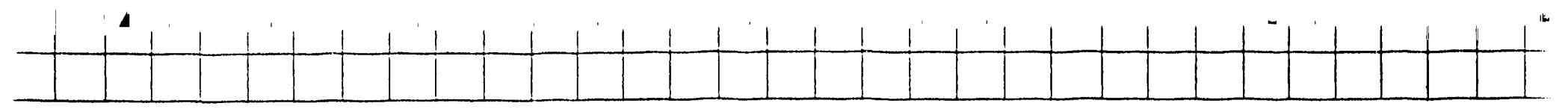

CRYSTOLON SILICON CARBIDE CASTABLE

March 1989

LC 904

LC9O4 is an extremely dense high purity silicon carbide castable designed specificaliy for use on studded tube walls in boilers. It utilizes Norton Company's exclusive CRYSTOLON silicon carbide and a hydraulic bond to achieve its unique high strength properties that develop within 12-24 hours after instaliation. High strength development in this calcium aluminate bonded monolithic occurs throughout its applied thickness whereas heat setting mixes develop minimum strengths in the cool areas adjacent to water cooled tubes. These features aliow its usage along grate lines where erosion can be very severe. on the upper tube wall areas, its high thermal conductivity allows maximum heat transfer which assures minimum ash/siag buildup.

It can be installed using conventional gunning and casting techniques. To achieve maximum physical and heat transfer properties, gunning is recommended.

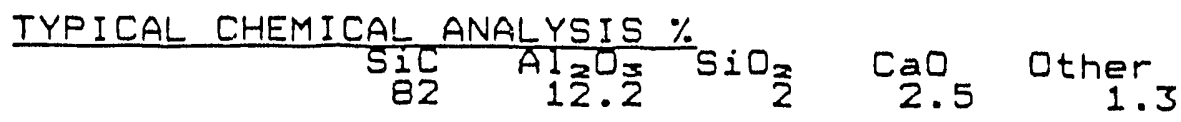

TYPICAL PHYSICAL PROPERTIES

$\begin{array}{lll}\text { Grain } & \text { Installed } & \text { Maximum Use } \\ \text { Size } & \begin{array}{l}\text { Density } \\ \text { Ibs/fts }\left(\mathrm{Kg} / \mathrm{m}^{3}\right)\end{array} \\ \text { loF } & 160(2563) & 29000 \mathrm{~F} \\ & & 15930 \mathrm{C}\end{array}$

THERMAL CONDUCTIVITY ASTM C202 BTU.in/(hr.ftz deg.F) (W/mK)

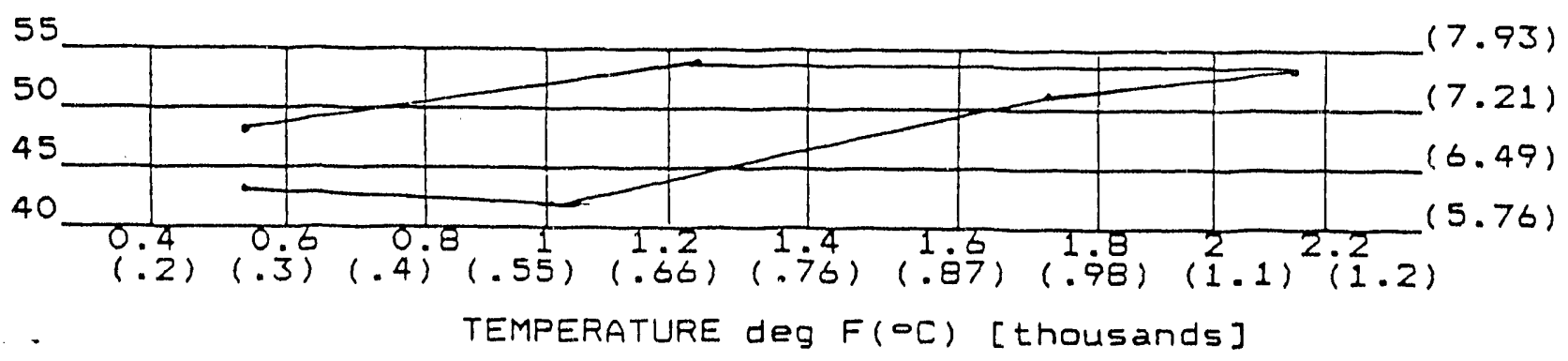

COLD CRUSHING STRENGTHS

$\begin{array}{ccccc} & \begin{array}{c}\text { After Firing TO: } \\ 2120 \mathrm{~F}\end{array} & 9320 \mathrm{~F} & 18320 \mathrm{~F} & 25520 \mathrm{~F} \\ (1000 \mathrm{C}) & (5000 \mathrm{C}) & (10000 \mathrm{C}) & (14000 \mathrm{C}) \\ \text { PSI } & 11000 & 15000 & 18000 & 20000 \\ \text { MPa } & 76 & 103 & 124 & 139\end{array}$

CQLD \& HOT MODULUS OF RUPTURE

\begin{tabular}{|c|c|c|c|}
\hline $\begin{array}{l}\text { After } \\
\text { Dried }\end{array}$ & $\begin{array}{c}\text { Firing to } \\
3920 \mathrm{~F} \\
(2000 \mathrm{C})\end{array}$ & $\begin{array}{c}\text { / Holding at } \\
7520 F \\
(4000 \mathrm{C})\end{array}$ & $\begin{array}{l}11120 F \\
(600-C)\end{array}$ \\
\hline $\begin{array}{l}700 \\
12\end{array}$ & $\begin{array}{c}1700 / 1500 \\
12 / 10\end{array}$ & $\begin{array}{c}2200 / 2200 \\
15 / 15\end{array}$ & $\begin{array}{c}2400 / 2300 \\
17 / 16\end{array}$ \\
\hline
\end{tabular}

ABRASION LOSS (ASTM C7O4) 10 CC 
PACKAGING - Supplied dry in $1001 \mathrm{~b}(45.4 \mathrm{~kg})$ polyethylene lined paper bags standard pallet weight size is 3000 ibs (1364 Kg)

SHELF LIFE - Twelve months when stored under optimum cool \& dry conditions. INSTALLATION - Instructions and supervision are available. "PERFORMANCE NOT PRICE DETERMINES REFRACTORY COST." 


\title{
ADVANCED CERAMICS
}

\section{CRYSTON SILICON NITRIDE BONDED SILICON CARBIDE $\mathrm{CN}-183$}

\begin{abstract}
This is a new high bond content nitride bonded silicon carbide that has exceptional abrasion resistance and outstanding oxidation resistance in the 1650 to $20000 \mathrm{~F}$ (900-11000C) temperature range.

Principal uses have been as tube blocks in fluidized bed boiler applications where long life is important and wear of refractory components is a concern.
\end{abstract}

CN-183 is available in tubes, brick and other heavy shapes.

\section{Typical Characteristics:}

Density

Modulus of Elasticity

Chemical Analysis

Silicon Carbide

Bond $\left(\mathrm{Si}_{5} \mathrm{~N}_{4}\right)$

Oxides

Maximum Use Temperature

Apparent Porosity

Modulus of Rupture

room temperature

$22800 \mathrm{~F}$ (12500C)

$26400 \mathrm{~F}(14500 \mathrm{C})$

Thermal Conductivity

$$
\begin{array}{ll}
6000 \mathrm{~F} & (3150 \mathrm{C}) \\
12000 \mathrm{~F} & (6490 \mathrm{C}) \\
18000 \mathrm{~F} & (9820 \mathrm{C}) \\
21000 \mathrm{~F} & (11490 \mathrm{C})
\end{array}
$$

Linear Thermal Expansion

$\begin{aligned} \text { per of }(90-27300 \mathrm{~F}) & 2.7 \times 10^{-0} \\ \text { per oC }(30-15000 \mathrm{C}) & 5.0 \times 10^{-6} \\ \text { Abraision LOSS (ASTM C704) } & 5 \mathrm{CC}\end{aligned}$

$1631 \mathrm{bs} .1 \mathrm{ft} .=(2.65 \mathrm{Mg} / \mathrm{m}=)$
$19 \times 104 \mathrm{psi}(130 \mathrm{GPa})$
$\%$
78
20
2
$29000 \mathrm{~F} \quad(15900 \mathrm{C})$
$15 \%$
$p 5 i$
$6500 \quad \mathrm{MPa}$
$7500 \quad 44$
$5300 \quad 51$

BTU - in. $w$

hr. ft. $=$ of $m \cdot k$

$113 \quad 16.3$

$120 \quad 17.3$

$104 \quad 15.0$

$100 \quad 14.4$

"PERFORMANCE NOT PRICE DETERMINES REFRACTORY COST."

Norton Company Advanced Ceramics / 1 New Bond Street, Box Number 15008, Worcester, MA 01615-0008 (508) 795-5000

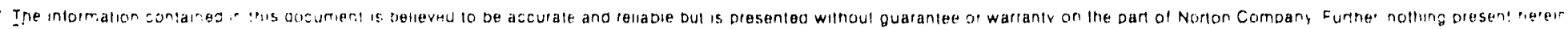
sncivid be inierpreted as an authorization or inducement 10 praclice any patented invention without an approprlate license 
BOILER WALL ACCURACY

Boiler waterwalls are fabricated in panel sections in the shop and these sections are welded together at the job site. Tube spacing in the shop welded panels is usually very accurate, but panels welded together in the field may have wide welds at the membrane between sections.

For nominal tube spacing of $3^{\prime \prime}$ the field welds at section edge may cause a spacing of up to $3-1 / 4$ " between tubes. The shiplap on the CRYSTON tube block will usually allow coverage oi spacing up to 1/4" above nominal (3-1/4" in this example). If a wider spacing is encountered, the block will have to be mounted on adjacent tubes and block cut to fit.

\section{BLOCK ORIENTATION IN THE BOILER AND START OF INSTALLATION}

Refer to Figure 1. Block should be installed with the inside (fire side) of the shiplap pointing down.

In fluidized bed boilers the motion of the solids at the wall is generally downward due to boundary layer effects, so the inside shiplap should be installed downward. Installation should start at the bottom of the pattern..

In incinerators the inside shiplap is installed down so that slag or ash will not run in behind the tile. When the inside shiplap is installed down, the installation should start at the bottom of the tila pattern in the unit.

\section{INSTALLATION STEPS}

1. Build necessary scaffolding.

2. Measure and mark area to be covered with block.

z. Sandblast all tubes in the area to be covered; removing all paint, rust, dirt or other foreign substances.

4. Refer to specifications for that boiler and mark where the top row of studs is to be welded. This line can be established by first marking the location of the studs on the two edges of the wall and snapping a chalk line between these two points. The line must be straight. The studs may be on the center line of the tube or on the membrane. Check blueprint for tile installation. 
5. Location of all other studs can be found by:

(a) use of a template that has the stud pattern accurately located or

(b) by measuring from the first row of studs and using a chalk line to establish a straight line between each row of studs. The location of individual studs is then marked on the centerline of the correct tubes (or on the membrane).

6. Accuracy of stud placement should be within 1/16". The tube block have 1/8" space between blocks when perfectly positioned so if adjacent tile are both-1/16 on position there will be interference between block and they will have to be cut to provide clearance. Correct stud spacing will save this cutting.

7. If tube spacing is less than nominal, and there is an interference fit, edges of the block must be cut to provide clearance. See figure 2. If tube spacing at panel welds is too great then the stud spacing must be changed so that block is attached to adjacent tubes and block cut to fit. between those tubes. (figure 3 ) stud location must be checked for fit before studs are welded.

8. Once stud location is established, and fit is checked at panel welds, all studs can be welded. See boiler specification and welding code for welding procedure and testing of welds.

9. Mix the Norton CRYSTOLON LC959 mortar so that it is a thin consistency suitable for buttering the back of block.

10. Test mortar on block. If the mortar stiffens quickly when applied to the block, the block must be dampened with water.

11. Start at the bottom of the wall (unless the assembly blueprint differs from "Block Orientation" as described on page 2).

12. Mortar the block with LC959 mortar, taking care to avoid getting mortar in the shiplap joint. Place the tube block over a stud and press it firmly against the tube wall. Assemble washer (if required) and nut. Check block occasionally to be sure mortar fills all space between block and tube wall. 
13. Tighten nut as much as possible using a socket wrench. Then pound on the block with a leather or rubber mallet while continuing to tighten. When the nut is fully tightened using this method it should then be backed off slightly to relieve tension (less than $1 / 8$ turn).

14. Nuts must be tightened within approximately 10 minutes after tlock is mortared to ensure a good fit to tubes. If too long a period elapses between mortaring of block and tightening, the mortar will stiffen and the block will not seat snug to the tubes. This would reduce heat transfer to the water wall from the block.

15. Cut block to fit als required around openings and at edges of the patter?. Blolk should not overhang an opening as ramming of cement behind the block may break it. Cuts should ie at least 3/4" from the stud hole in the block. see figure 4. If block is too tight, cut edge to provide clearance between block. Cut both steps of shiplap. Do not remove shiplap.

16. At panel welds on the water wall cut or noteh the back of the block to clear the welds allowing the block to seat against tile tubes.

On vertical welds cut the "fin" on the block that is over the weld to clear the weld.

On horizontal welds the back of the block can be grooved with the diamond saw to clear the weld.

17. After all blocks are assembled, tack weid the nut to the stud using the welding rod specified by the boiler specification.

18. If required by the design, fill stud holes with cement such as Norton LC959 silicon Carbide mortar.

\section{DRY OUT AND INITIAL HEATING}

Because there is little moisture in the block and in the LC959 mo-tar behind it, the heding schedule dictated by other refractories in the unit will be satisfactory for the CRYSTON tuie block system. Once installed and before sufficient heat has been introduced to eliminate all moisture from Norton's Crystolon mortar it must not be allowed to be frozen. Water aroands when it freezes and this will, at the least, weaken the "oundness of the mortar. 
PLIBRICO 


\section{FLUIDIZED BED INBTALLATIONS}

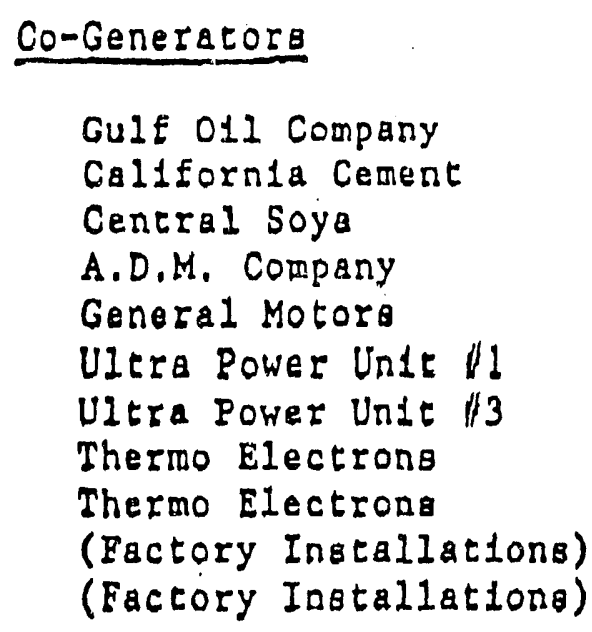

Sewage

Lincoln Park

Onleda County

key west Uaste Watek Tieentmours

city of Dubuque

\section{Dryerg}

Blue C1relo Atlant1c Cemeat J.R. Simplot

\section{Black Liguer \\ Stone Consainor \\ Weston Paper}

Locat1ons

Bakers 1 e1d, $C A$

Colton, CA

Chattanooga, TN

Manketo, MN

Fort Wagne, IN

Burney, CA

Blua Lake, CA

Mendotta, CA

Woodland, CA

York, PA

Ferrysburg, MI

LocatLona

IIncoln Park, NJ

Ut1ca, $N$

Key Hest, BL

Dubuque, IA

Locat Lons

Sparrows Polnt, MD Pocatel1a, ID

Locat1ons

Ontonogon, MI Terce Baute, IN
Designers

Pyropowar

Pyropower

Pyropower

Asea Stal

Riley

UItra Power

UItra Power

Gotaverken

Gotzverken

York shipley

Johnston Boller

De日18nerg

Doter oliver

Z1mpro

$2 \operatorname{sip} r 0$

Copeland

Degigners

Dort 021ver

Dorr Oliver

Des1gners

Copetech

Dorr Oliver
New or

Repalr

New $(C F B)$

New $(C F, 3)$

New $(\angle F B)$

New

New (CFO)

Repatr $K F / 3$,

Repair ( $C F B$ )

Niew

New

New

New

New or

Repa1r

Repalf

New

New

Repalr

New or

RePQ15

Repalr

Repalr

New or

Repa1s

New

Repads

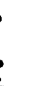




\section{A COMPLETE CHOICE OF REFRACTORY PRODUCTS AND SERVICES}

Traditional Plibrico plastics, Plicast castables Pllgun gunning mixes, and Plistlx servicing/lnjec. tlon mixes all add up to provide a wide variety of solutions for your refractory requirements, whatever the appllcation.

$$
\text { isonds }
$$

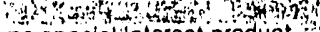
A brief description of some special interest product Anes follows below, with laboratory data on the suct ceeding pages. Consult your local Plibrico representatlve for additlonal current selectlons monom

\section{FEATURING ...}

\section{PLICAST ' H'MMOR* SERIEs CASTABLES}

The original low cement castable for applications requiring superior hot strengths and the ability to resist abrasion. With years of proven cost iffective servce in severe environments. the HyMOR tamily of materiais can solve your problems in hign tem. perature ranges.

PLICAST 'HREZIST' SERIES CASTABLES A Oow moisture design for doplicalions that demand aurasion resistant qualities, and the stength to sund uo to abusive oderating conditions H.RE-IST Serles castables also ofter innerent flow provertles that nake placement simple. An excel. lent pertormer at iow to intermediate temperature ranges

\section{THE HRATE' PROCESS}

Comoining the soeed and ease of installation allow. ed oy zuming with the iechnology of plastlc retrac

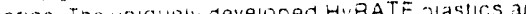
a pestructured plasti: retractory. designed loi pnuematic placement. while relaining all the eneticial properties ot the grades trom snich they were jeriveo
THE A.LSTUSFF" SYSTEM

A famly of non.welting aluminum refractories, in Aluding plastics, castaoles, and gunning mixes. The special formulation, fortified with a surface barrier that is impenetrable at normal operating conditions, yelds longer life and less downtime. From the metal line to the sub.hearth, including insulating meteriais, AL.TUFF producls make aluminum production less of a challenge.

\section{DPDSTOX "Injec.Tite" PROCESS}

A mumpade retracion process for genera boller and 'urnace repar apouc atuons the ceratulc fiber baseg niection mix is designed to reslore Norn in sulation and fill volds between a relractory lining ano shell. Material is apolied through furnace $\theta x$ teriot ya pneumatic pump. While the unit is elther on-ilne or down.

\section{FerREZIST'SERIES}

A ine ol zrapnite enficned refractories specillcally designed tor Jemanding upplications in the loundry industry. Ottering excellent resistance to terrous metals onetration and slag allack. while retaining the fiels oroven snysical properties of the trad thonat Plibrico procucts

\section{ADDITIONAL PLIBRICO PRODUCTS}

TEDI.SHAPES

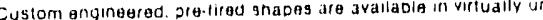
irmled sizes. confligurations. and weignis. Wharaver a recurring weat cone dernands gxtlia ellention, the Redi.Shapy conceo allowg instant mainlenance.

Re(1).gnades can be cast or ramed of reftactorles tully compat ble with your axisting lining Select trom axotic malertals formic

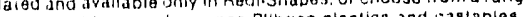
traditional nign pertormance Plibricio olastics and sastables DRY SKID BLOCK

to furnace hearth tequirements

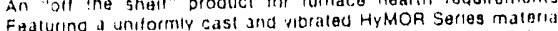
with gxcellent esistance to scale and slay sllack. With pre-tled skid block, downtime ig iminimized. Choose lrom d varlety of sizes tor simpie inslallalion.

PLISUL.GRIP COMPONENTS

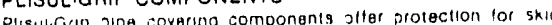
Plisul.Grí JiDe covering componanis Jlat the suvere gervic Dones it proing network, Plisul.Grip stands ud lo slagginc an nign temperalures. while providing an inguliding offlelency tha culs Dare Dor neal loss by $80 \% 1090 \%$

PLISULATE BLOCK INSULATION

1wo grades, 1900 ant Pholuta olock insulation is dvallablo in iwo grades, rena

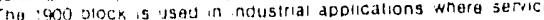

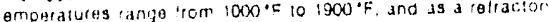

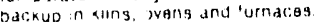

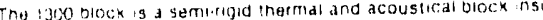

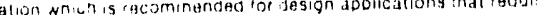
producis

PLISULATE CEMENT

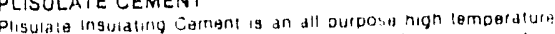

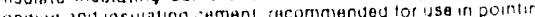
Dre

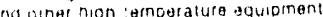

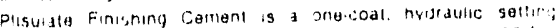

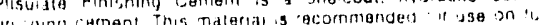

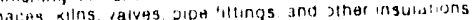
ANCHOAS

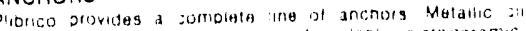

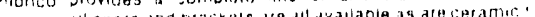
monks.

SERVICE

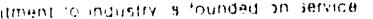

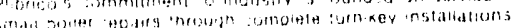

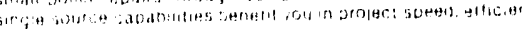
ant acomen, 


\begin{tabular}{|c|c|c|c|c|c|}
\hline $\begin{array}{l}\text { PLIDT'LCQ } \\
\text { PLASTIC REFRACTORY }\end{array}$ & $\begin{array}{l}\text { PLIBAICO } \\
\text { SUPER } \\
\text { SUR BOND }\end{array}$ & $\begin{array}{l}\text { PLIBRICO } \\
\text { SUPER F } \\
\text { AIR BOND }\end{array}$ & 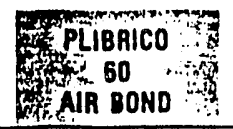 & $\begin{array}{c}\text { PLIBRICO } \\
80 \\
\text { AIR BOND }\end{array}$ & 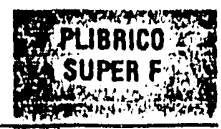 \\
\hline $\begin{array}{l}\text { Recommended Service Limit of } \\
\text { Setting Characteristics }\end{array}$ & A 2800 & $\begin{array}{l}2900 \\
\text { Air \& Heat }\end{array}$ & Alr \& Heal & $\begin{array}{c}3300 \\
\text { Air \& Heat }\end{array}$ & gyot 2900 \\
\hline $\begin{array}{l}\text { Packaging lbs/ctn } \\
\text { Shell Life-Months }\end{array}$ & $\begin{array}{l}2100 \\
12\end{array}$ & $\begin{array}{r}100 \\
12\end{array}$ & 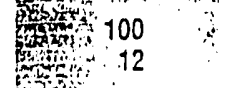 & $\begin{array}{r}100 \\
12\end{array}$ & $40+100$ \\
\hline $\begin{array}{l}\text { Weight to Place lbs } / \mathrm{tt}^{3} \\
\text { Weight in Service lbs } / \mathrm{tt}^{3}\end{array}$ & $\begin{array}{ll}142 \\
132\end{array}$ & $\begin{array}{l}148 \\
138\end{array}$ & $\begin{array}{l}154 \\
40\end{array}$ & $\begin{array}{l}170 \\
158\end{array}$ & $\begin{array}{ll}2 \\
148 \\
138\end{array}$ \\
\hline Min. Time Betore Firing & None & None & None & None & None \\
\hline $\begin{array}{l}\text { Typical Chemical Analysis-\% } \\
\mathrm{Al}_{2} \mathrm{O}_{3} \\
\mathrm{SiO}_{2} \\
\mathrm{Fe}_{2} \mathrm{O}_{3} \\
\mathrm{TiO}_{2} \\
\mathrm{CaO} \\
\mathrm{MgO} \\
\mathrm{Alk}\end{array}$ & 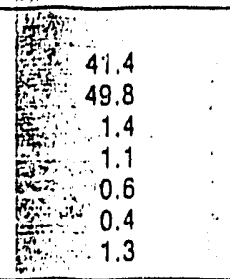 & $\begin{array}{r}41.6 \\
50.9 \\
1.4 \\
1.5 \\
0.5 \\
0.1 \\
0.5\end{array}$ & 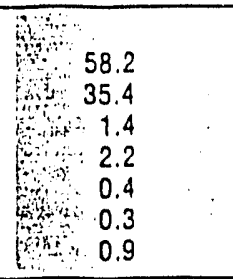 & $\begin{array}{r}79.1 \\
14.8 \\
2.4 \\
2.1 \\
0.2 \\
0.1 \\
0.2\end{array}$ & 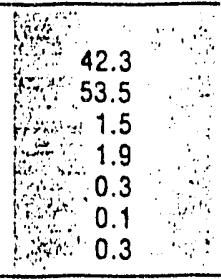 \\
\hline $\begin{array}{l}\text { Permanent Linear Change-\% } \\
\text { ASTM C. } 179 \\
@ 230 \mathrm{~F} \\
@ 1000 \mathrm{~F} \\
@ 1500 \mathrm{~F} \\
@ 2000 \mathrm{~F} \\
@ 2500 \mathrm{~F} \\
@ 3000 \mathrm{~F}\end{array}$ & 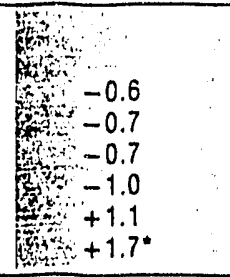 & $\begin{array}{l}-0.6 \\
-0.7 \\
-0.7 \\
-1.0 \\
+0.5 \\
+1.0\end{array}$ & $\begin{aligned} & \\
& 5+-0.7 \\
&-0.8 \\
&-0.8 \\
&-1.0 \\
&+0.9 \\
&+1.6\end{aligned}$ & $\begin{array}{l}-0.7 \\
-0.8 \\
-0.8 \\
-1.0 \\
+0.2 \\
+2.0\end{array}$ & 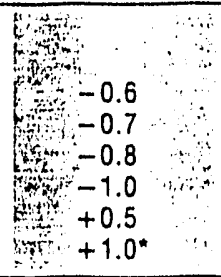 \\
\hline $\begin{array}{l}\text { Cold Modulus of Rupture-psi } \\
\text { ASTM C-491 } \\
@ 230 \mathrm{~F} \\
@ 1000 \mathrm{~F} \\
@ 1500 \mathrm{~F} \\
@ 2000 \mathrm{~F} \\
@ 2500 \mathrm{~F} \\
@ 3000 \mathrm{~F}\end{array}$ & 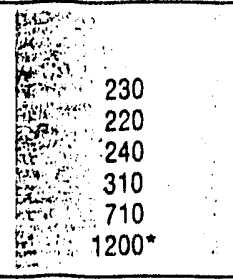 & $\begin{array}{r}350 \\
300 \\
300 \\
450 \\
600 \\
1500^{\star}\end{array}$ & 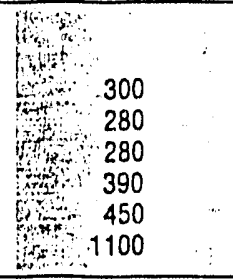 & $\begin{array}{r}350 \\
350 \\
350 \\
500 \\
500 \\
1000\end{array}$ & 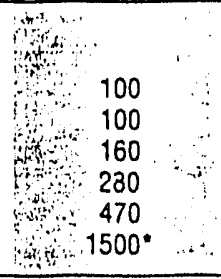 \\
\hline $\begin{array}{l}\text { Hot Modulus of Rupture-psi } \\
\text { ASTM C-583 } \\
@ 1000 \mathrm{~F} \\
@ 1500 \mathrm{~F} \\
@ 2000 \mathrm{~F} \\
@ 2500 \mathrm{~F}\end{array}$ & 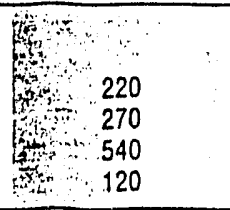 & $\begin{array}{l}300 \\
450 \\
800 \\
150\end{array}$ & 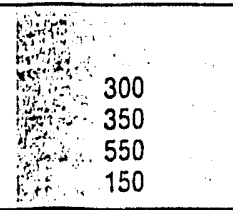 & $\begin{array}{l}300 \\
500 \\
900 \\
200\end{array}$ & 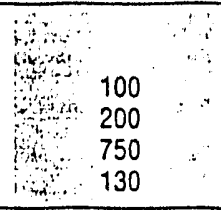 \\
\hline $\begin{array}{l}\text { Cold Crushing Strength-psi } \\
\text { ASTM C- } 133 \\
\text { @ } 230 \mathrm{~F} \\
@ 1500 \mathrm{~F}\end{array}$ & $\begin{array}{l}4 \\
4\end{array}$ & $\begin{array}{r}700 \\
1200\end{array}$ & 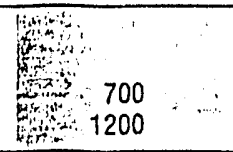 & $\begin{array}{r}700 \\
1200\end{array}$ & 250 \\
\hline $\begin{array}{l}\text { Thermal Conductivity } \\
\text { btu. in } / \mathrm{hr} . \mathrm{tt}^{2} . \text { of } \\
@ 500 \mathrm{~F} \\
@ 1000 \mathrm{~F} \\
@ 1500 \mathrm{~F} \\
@ 2000 \mathrm{~F}\end{array}$ & 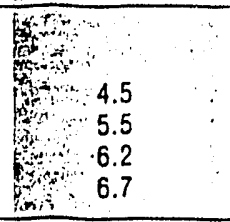 & $\begin{array}{l}4.5 \\
5.5 \\
6.2 \\
6.7\end{array}$ & $\begin{array}{ll} & \\
7 & 4.8 \\
& 6.0 \\
7 & 6.8 \\
& 7.2 \\
\end{array}$ & $\begin{array}{l}11.8 \\
10.7 \\
10.5 \\
10.3\end{array}$ & 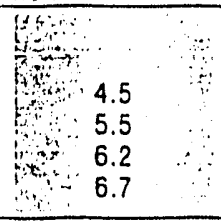 \\
\hline Bake Out Schedule & $B, A$ & A & $\because$ & A & $\therefore A$ \\
\hline $\begin{array}{l}\text { Applicable Specifications } \\
\text { ASTM C }-673\end{array}$ & $\begin{array}{l}\text { Super } \\
\text { Duty }\end{array}$ & $\begin{array}{l}\text { Super } \\
\text { Duty }\end{array}$ & Alumina & $\begin{array}{l}80 \% \\
\text { Alumina }\end{array}$ & $\begin{array}{l}\text { Super } \\
\therefore \text { Duty }\end{array}$ \\
\hline $\begin{array}{l}\text { Product Number } \\
\text { - Al Service Limit }\end{array}$ & 10006 & 10008 & 10013 & 10016 & 10007 \\
\hline
\end{tabular}

Note: All figures are averaged results of laboratory ASTM lests: reasonable variations can be expected. Thermal conductivity will vary depending upon installation technique and thermal treatment. Data should not be used for specification purposes 
Plibr-ico:

\begin{tabular}{|c|c|c|c|c|c|c|c|c|c|}
\hline $\begin{array}{l}\text { PLASTIC } \\
\text { REFRACTORY }\end{array}$ & $\begin{array}{l}\text { PLIBRICO } \\
55-S\end{array}$ & $\begin{array}{l}\text { PLIBRICO } \\
\text { SR. } 68\end{array}$ & $\begin{array}{l}\text { PLIBRICO } \\
\text { GB.S }\end{array}$ & $\begin{array}{l}\text { PLIBRICO } \\
\text { SR-85 }\end{array}$ & $\begin{array}{c}\text { PLIBRICO } \\
\text { 85-S } \\
\text { Special }\end{array}$ & $\begin{array}{l}\text { PLIBAICO } \\
85.5\end{array}$ & $\begin{array}{l}\text { PLIBRICO } \\
\text { SR.90 }\end{array}$ & $\begin{array}{l}\text { PLIBRICO } \\
90 . S\end{array}$ & $\begin{array}{l}\text { PLIBRICO } \\
\text { SIC } \\
80\end{array}$ \\
\hline $\begin{array}{l}\text { Recommended Service Limit }{ }^{\circ} \mathrm{F} \\
\text { Setting Characteristics }\end{array}$ & $\begin{array}{l}3000 \\
\text { Chemical }\end{array}$ & $\begin{array}{l}3100 \\
\text { Chemical }\end{array}$ & $\begin{array}{c}3100 \\
\text { Chemical }\end{array}$ & $\begin{array}{c}3300 \\
\text { Chemical }\end{array}$ & $\begin{array}{l}3300 \\
\text { Chemical }\end{array}$ & $\begin{array}{c}3300 \\
\text { Chemical }\end{array}$ & $\begin{array}{l}3400 \\
\text { Chemical }\end{array}$ & $\begin{array}{c}3400 \\
\text { Chemical }\end{array}$ & $\begin{array}{c}2700 \\
\text { Chemical }\end{array}$ \\
\hline $\begin{array}{l}\text { Packaging lbs / ctn } \\
\text { Shell Lite-Months }\end{array}$ & $\begin{array}{r}100 \\
4\end{array}$ & $\begin{array}{r}100 \\
4\end{array}$ & 100 & $\begin{array}{r}100 \\
4\end{array}$ & $100 \%$ & $\begin{array}{r}100 \\
4\end{array}$ & 100 & $\begin{array}{r}100 \\
3\end{array}$ & 100 \\
\hline $\begin{array}{l}\text { Weight to Place lbs } / \mathrm{ft}^{3} \\
\text { Weight in Service lbs } / \mathrm{ft}^{\mathrm{s}}\end{array}$ & $\begin{array}{l}156 \\
141\end{array}$ & $\begin{array}{l}163 \\
150\end{array}$ & $\begin{array}{l}162 \\
152, y\end{array}$ & $\begin{array}{l}178 \\
165\end{array}$ & $\begin{array}{c}184 \\
170\end{array}$ & $\begin{array}{l}185 \\
171\end{array}$ & $\begin{array}{l}187 \\
172\end{array}$ & $\begin{array}{l}188 \\
187\end{array}$ & 160 \\
\hline Min. Time Before Firing & None & None & None & None & None & None & None & None & None, ${ }_{3}$ \\
\hline $\begin{array}{l}\text { Typical Chemical Analysis-\% } \\
\mathrm{Al}_{2} \mathrm{O}, \\
\mathrm{SiO}_{2} \\
\mathrm{Fe}_{2} \mathrm{O}_{1} \\
\mathrm{TiO}_{2} \\
\mathrm{CaO} \\
\mathrm{MgO} \\
\mathrm{Alk} \\
\mathrm{P}_{2} \mathrm{O}_{4} \\
\mathrm{SiC}\end{array}$ & 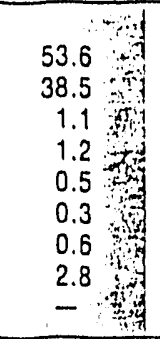 & $\begin{array}{r}69.0 \\
25.5 \\
0.9 \\
1.0 \\
0.1 \\
0.1 \\
0.2 \\
2.7 \\
-\end{array}$ & 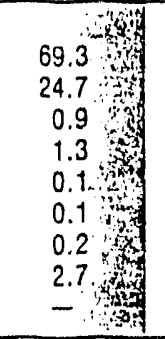 & $\begin{array}{r}83.1 \\
10.1 \\
1.1 \\
1.7 \\
0.1 \\
0.1 \\
0.2 \\
2.7 \\
-\end{array}$ & $\begin{array}{l}8.2 \\
8.2 \pi \\
1.2 \\
1.8 \\
0.2 \\
0.2 \\
0.2 \\
2.7 \\
-1\end{array}$ & $\begin{array}{r}86.0 \\
9.3 \\
0.2 \\
0.2 \\
0.2 \\
0.2 \\
0.2 \\
2.8 \\
-\end{array}$ & $\begin{array}{l}0.7 \\
90.3 \\
0.2 \\
0.1 \\
0.1 \\
0.1 \\
0.2 \\
2.7 \\
-1\end{array}$ & $\begin{array}{r}93.0 \\
3.4 \\
0.2 \\
0.4 \\
0.1 \\
0.1 \\
0.2 \\
1.6 \\
-\end{array}$ & 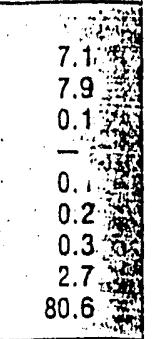 \\
\hline $\begin{array}{l}\text { Permanent Linear Change-\% } \\
\text { ASTM C.179 } \\
@ 230 \mathrm{~F} \\
@ 1000 \mathrm{~F} \\
@ 1500 \mathrm{~F} \\
@ 2000 \mathrm{~F} \\
@ 2500 \mathrm{~F} \\
@ 3000 \mathrm{~F}\end{array}$ & $\begin{array}{l}\text { nd } \\
-0.4 \\
-0.5 \\
-0.5 \\
-0.6 \\
-0.3 \\
0.0\end{array}$ & $\begin{array}{l}-0.5 \\
-0.6 \\
-0.7 \\
-0.5 \\
-0.1 \\
-0.5 \\
\end{array}$ & $\begin{array}{l} \\
-0.4 \\
-0.4 \\
-0.4 \\
-0.4 \\
+0.2 \\
+0.6\end{array}$ & $\begin{array}{l}-0.6 \\
-0.7 \\
-0.6 \\
-0.5 \\
+0.5 \\
-0.6 \\
\end{array}$ & $\begin{array}{l}\text { } \\
-0.4 \\
-0.5 \\
-0.6 \\
-0.6 \\
+0.1 \\
-0.8\end{array}$ & $\begin{array}{l}-0.4 \\
-0.5 \\
-0.6 \\
-0.6 \\
+0.2 \\
-0.6\end{array}$ & $\begin{array}{l}\text { m } \\
-0.8 \\
-1.0 \\
-1.1 \\
-1.3 \\
-0.8 \\
-1.5\end{array}$ & $\begin{array}{l}-0.5 \\
-0.6 \\
-0.6 \\
-0.6 \\
-0.9 \\
-1.4 \\
\end{array}$ & $\begin{array}{l}10 \\
-0.3 \\
-0.4 \\
-0.5 \\
-0.2 \\
-0.4 \\
-1.3\end{array}$ \\
\hline $\begin{array}{l}\text { Cold Modulus of Rupture-psi } \\
\text { ASTM C.491 } \\
@ 230 \mathrm{~F} \\
@ 1000 \mathrm{~F} \\
@ 1500 \mathrm{~F} \\
@ 200 \mathrm{~F} \\
@ 2500 \mathrm{~F} \\
@ 3000 \mathrm{~F}\end{array}$ & $\begin{array}{r}920 \\
1100 \\
1100 \\
1500 \\
2500\end{array}$ & $\begin{array}{l}1130 \\
1580 \\
1600 \\
1980 \\
2900 \\
4500\end{array}$ & $\begin{array}{l}10 \\
1200 \\
1700 \\
1250 \\
1400 \\
2050 \\
3100\end{array}$ & $\begin{array}{l}1240 \\
1750 \\
1870 \\
2400 \\
2500 \\
2800\end{array}$ & $\begin{array}{l}6 \\
1300 \\
1900 \\
2000 \\
2200 \\
2500 \\
3000\end{array}$ & $\begin{array}{l}1300 \\
2000 \\
2000 \\
2400 \\
2500 \\
2100\end{array}$ & $\begin{array}{l}1200 \\
2000 \\
1800 \\
2400 \\
2500 \\
3000\end{array}$ & $\begin{array}{l}1200 \\
1400 \\
1600 \\
1900 \\
2400 \\
3100\end{array}$ & $\begin{array}{l}1000 \\
1100 \\
1200 \\
1200 \\
2000 \\
3200 *\end{array}$ \\
\hline $\begin{array}{l}\text { Hot Modulus of Rupture-psi } \\
\text { ASTM C-583 } \\
@ 1000 \mathrm{~F} \\
@ 1500 \mathrm{~F} \\
@ 2000 \mathrm{~F} \\
@ 2500 \mathrm{~F}\end{array}$ & $\begin{array}{r}1250 \\
1750 \\
900 \\
600\end{array}$ & $\begin{array}{l}2000 \\
2400 \\
1200 \\
1100\end{array}$ & $\begin{array}{l}1600 \\
2000 \\
1200 \\
1100\end{array}$ & $\begin{array}{r}1500 \\
1900 \\
900 \\
600\end{array}$ & $\begin{array}{r}1400 \\
2000 \\
1000 \\
750\end{array}$ & $\begin{array}{r}1300 \\
2400 \\
1800 \\
500\end{array}$ & $\begin{array}{r}2000 \\
2000 \\
1200 \\
400\end{array}$ & $\begin{array}{r}1700 \\
1900 \\
900 \\
500\end{array}$ & $\begin{array}{r}1100 \\
1300 \\
1300 \\
700\end{array}$ \\
\hline $\begin{array}{l}\text { Cold Crushing Strength-psi } \\
\text { ASTM C. } 133 \\
\text { @ } 230 \mathrm{~F} \\
\text { @ } 1500 \mathrm{~F}\end{array}$ & $\begin{array}{r}1200 \\
300\end{array}$ & $\begin{array}{l}1900 \\
6000\end{array}$ & 2000 & $\begin{array}{r}1900 \\
600\end{array}$ & 2000 & $\begin{array}{r}2200 \\
800\end{array}$ & $\begin{array}{r}2000 \\
800\end{array}$ & $\begin{array}{l}2000 \\
7500\end{array}$ & $\begin{array}{l}1700 \\
3400\end{array}$ \\
\hline $\begin{array}{l}\text { Abrasion Loss-cc's } \\
\text { AST.M C. } 704 \\
\text { After } 1500 \mathrm{~F}\end{array}$ & 13 & 7 & 8 & 6 & 8 & 8 & 4 & 6 & 12 \\
\hline $\begin{array}{l}\text { Thermal Conductivity } \\
\text { btu. in } / \mathrm{hr} . \mathrm{H}^{2} .{ }^{\circ} \mathrm{F} \\
\text { @ } 500 \mathrm{~F} \\
\text { @1000F } \\
\text { @1500F } \\
\text { @2000F }\end{array}$ & $\begin{array}{l}4.8 \\
6.0 \\
6.8 \\
7.2\end{array}$ & $\begin{array}{l}8.9 \\
8.5 \\
8.5 \\
9.1\end{array}$ & $\begin{array}{l}8.9 \\
8.5 \\
8.5 \\
9.1\end{array}$ & $\begin{array}{l}13.0 \\
11.8 \\
10.9 \\
11.3\end{array}$ & $\begin{array}{l}13.0 \\
11.8 \\
10.9 \\
11.3\end{array}$ & $\begin{array}{l}16.5 \\
14.2 \\
13.0 \\
12.0\end{array}$ & $\begin{array}{l}18.1 \\
16.1 \\
14.6 \\
13.7 \\
\end{array}$ & $\begin{array}{l}18.1 \\
16.1 \\
14.6 \\
13.7\end{array}$ & $\begin{array}{l}72.0 \\
64.0 \\
55.0 \\
47.0\end{array}$ \\
\hline Bake Out Schedule & $D$ & $D$ & $0 \therefore$ & $D$ & D & $D$ & $D$ & 0 & $D$ \\
\hline $\begin{array}{l}\text { Applicable Specifications } \\
\text { ASTM C-673 }\end{array}$ & $\begin{array}{l}\text { Super } \\
\text { Outy }\end{array}$ & $\begin{array}{l}70 \% \\
\text { Alumina }\end{array}$ & $\begin{array}{c}70 \% \\
\text { Alumina }\end{array}$ & $\begin{array}{l}85 \% \\
\text { Alumina }\end{array}$ & $\begin{array}{r}85 \% \\
\text { Alumina }\end{array}$ & $\begin{array}{l}85 \% \\
\text { Alumina }\end{array}$ & $\begin{array}{c}90 \% \\
\text { Alumina }\end{array}$ & $\begin{array}{c}90 \% \\
\text { Alumina }\end{array}$ & - \\
\hline Product Number & 10011 & 10068 & $10037 \ldots$ & 10085 & 10035 & 10018 & $12011 \%$ & 10033 & 11075 \\
\hline
\end{tabular}

- At Service Limit

Note: All figures are averaged results of laboratory ASTM tests: reasonable variations can be expected. Thermat conductivity will vary depending upon installation technique and inermal treatment. vata snould not be used ior specification purposes. 
HRATF ${ }^{*}$ SERIES

FOR PNEUMATIC APPLICATIONS

Plibroice*

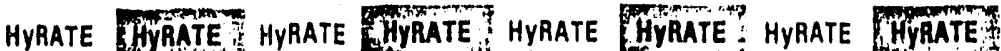

PLASTIC REFRACTORY

SUPER 60 68.S

-

Recommended Service Limit of

Setting Characteristics

Packaging los/bloc or carton

Shelf Life-Months

Weight to Flace lbs $/ \mathrm{tt}^{3}$

Weight in Service lbs $/ \mathrm{ft}^{3}$

Min. Time Before Firing

Typical Chemical Analysis-\%

$\mathrm{Al}_{2} \mathrm{O}_{3}$

$\mathrm{SiO}_{2}$

$\mathrm{Fe}_{2} \mathrm{O}_{3}$

$\mathrm{TiO}_{2}$
$\mathrm{CaO}$

$\mathrm{MaO}$

Alk

$\mathrm{P}_{2} \mathrm{O}_{3}$

$\mathbf{F}$

AIR

BOND

AlR $\rightarrow$ to

BOND

$2900 \quad 3200 \% 3300 \quad 3300$

AIR SPECIAL

BOND

Sxitis

ald

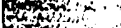

(3.)

Air \& Heat $3400 \because 3000$ \% 3100

\& Heat Ar \& Heat Chemical Ar \& Heat Chemical Chemical, Chemical Chemica

5

$\frac{\text { SiC }}{\text { Permanent Linear Change- } \%}$

ASTM C. 179

(Q) 230F

(G)1000F

(Q) $1500 \mathrm{~F}$

Q2.000F

(1)2500F

(B)3000F

15

55

कit?

$\therefore 58$

77

153 157

142

1. 148

None

None

160
152
165

None None

60 Nis

4 int 65

45 62 


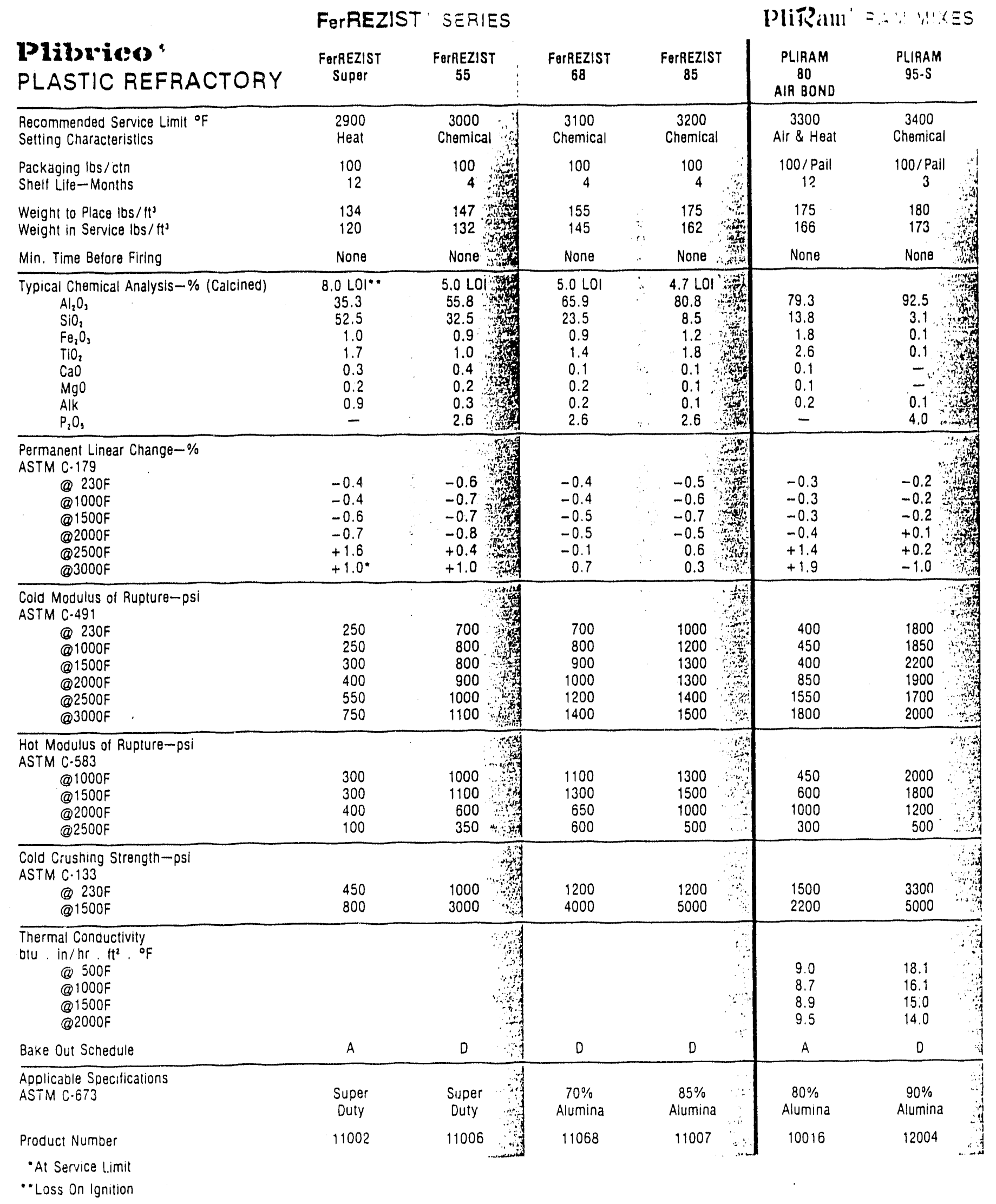

Note: All figures are averaged results of laboratory ASTM tests: reasonable variations can be expected. Thermal conductivity will vary depending upon installation technique and thermal treatment. Data should not be used for specification purposes. 


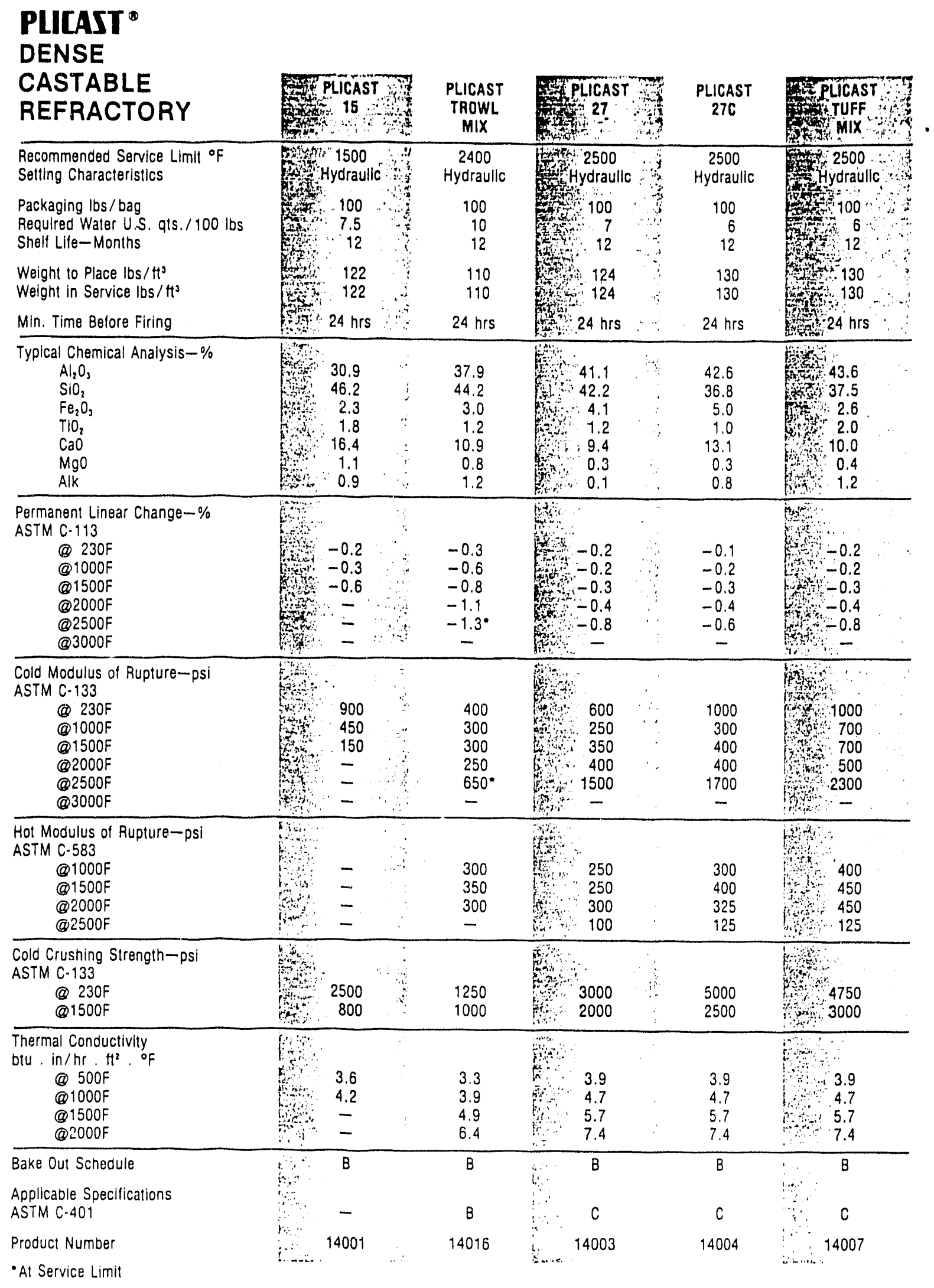

Note: All ligures are averaged results of laboratory ASTM lests: reasonable variations can be expected. Thermal conductivity will vary depending upon installation technique and thermal treatment Data should not be used for specification purposes. 


\section{PLICAST}

DENSE

CASTABLE

REFRACTORY

Recommended Service Limit of

Selling Characteristics

Packaging los / bag

Required Water U.S. qts/100 los

Shelf Life-Months

Weight 10 Place lbs $/ \mathrm{ft}^{\mathrm{s}}$

Weight in Service los $/ \mathbb{t t}^{3}$

Min. Time Belore Firing

\section{PLICAST}

STEEL MIX

2700

Hydraullc

100
6.25

12

135
135

Typical Chemical Analysis-\%

$\mathrm{Al}_{2} \mathrm{O}_{3}$

$\mathrm{SiO}_{2}$

$\mathrm{TiO}_{2}$

$\mathrm{CaO}$

$\mathrm{MgO}$

Alk

Permanent Linear Change- \%

ASTM C.113

(Q) $230 \mathrm{~F}$

(Q1000F

Q1500F

@2000F

@2500F

(1)3000F

Cold Modulus of Rupture-psi

ASTM C. 133

$$
\begin{aligned}
& \text { (1) } 230 \mathrm{~F} \\
& \text { @1000F } \\
& \text { @1500F } \\
& \text { @2000F } \\
& \text { @2500F } \\
& \text { @3000F }
\end{aligned}
$$

Hot Modulus of 'Rupture-psi

ASTM C.583

@1000F
@1500F
@2000F

@25COF

Cold Crushing Strength-psi

ASTM C. 133

$$
\text { @ } 230 \mathrm{~F}
$$

$24 \mathrm{hrs}$

59.9
33.0
0.9
0.2
5.0
0.2
0.5

0.5

PLICA

\begin{tabular}{cc} 
PLICAST & PLICAST \\
31 & KL MIX \\
\hline 2800 & 3000
\end{tabular}

ICAST

Hydraulle Hydraulic

3000

Hydraulic

100

100
7

100
7
12

$\begin{array}{rr}12 & 9 \\ 130 & 132\end{array}$

$130 \quad 132$

24 hrs

24 hrs

100

100
5.5
9

$142 \quad 155$

142 in 155

sing

53.3

$\begin{array}{rr}47.2 & 5.3 \\ 42.2 & 39.2 \\ 1.4 & 1.1\end{array}$

\begin{tabular}{|c|c|c|c|c|c|c|}
\hline $\begin{array}{l}\text { Thermal Conductivity } \\
\text { btu. in } / \mathrm{hr} . \mathrm{ft}^{2} .{ }^{\circ} \mathrm{F} \\
\text { @ } 500 \mathrm{~F} \\
@ 1000 \mathrm{~F} \\
@ 1500 \mathrm{~F} \\
@ 2000 \mathrm{~F}\end{array}$ & $\begin{array}{l}4.4 \\
5.3 \\
6.5 \\
8.3\end{array}$ & $\begin{array}{l}3.9 \\
4.7 \\
5.7 \\
7.4\end{array}$ & $\begin{array}{l}4.4 \\
5.3 \\
6.5 \\
8.3\end{array}$ & $\begin{array}{l}4.8 \\
5.7 \\
6.9 \\
8.7\end{array}$ & $\begin{array}{r}5.9 \\
7.1 \\
8.7 \\
11.3\end{array}$ & $\begin{array}{l}12.0 \\
11.0 \\
10.5 \\
11.0\end{array}$ \\
\hline Bake Out Schedule & $B$ & $B$ & B & $B$ & $B$ & $B$ \\
\hline $\begin{array}{l}\text { Applicable Specifications } \\
\text { ASTM C.401 }\end{array}$ & C & $D$ & $E$ & $E$ & $F$ & G \\
\hline Product Number & 14010 & 14006 & 14019 & 14053 & 14008 & 14010 \\
\hline
\end{tabular}

1.9 .01 .2

5.5 .40

$0.5 \bigcirc-0.2$

$1.1 \quad 0.4$

$24 \mathrm{hrs}$

$24 \mathrm{hrs}$

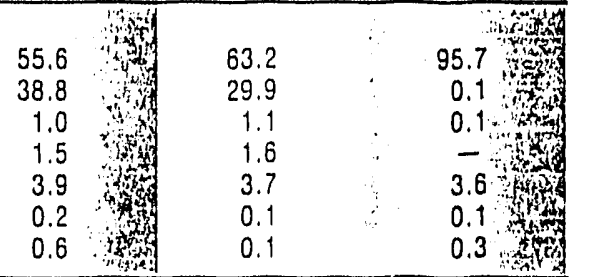

- At Service Limit

Note: All figures are averaged results of laboratory ASTM tests: reasonable variations can be expected. Thermal conductivity will vary depending upon installation technique and thermal treatment. Data should not be used for specification purposes. 


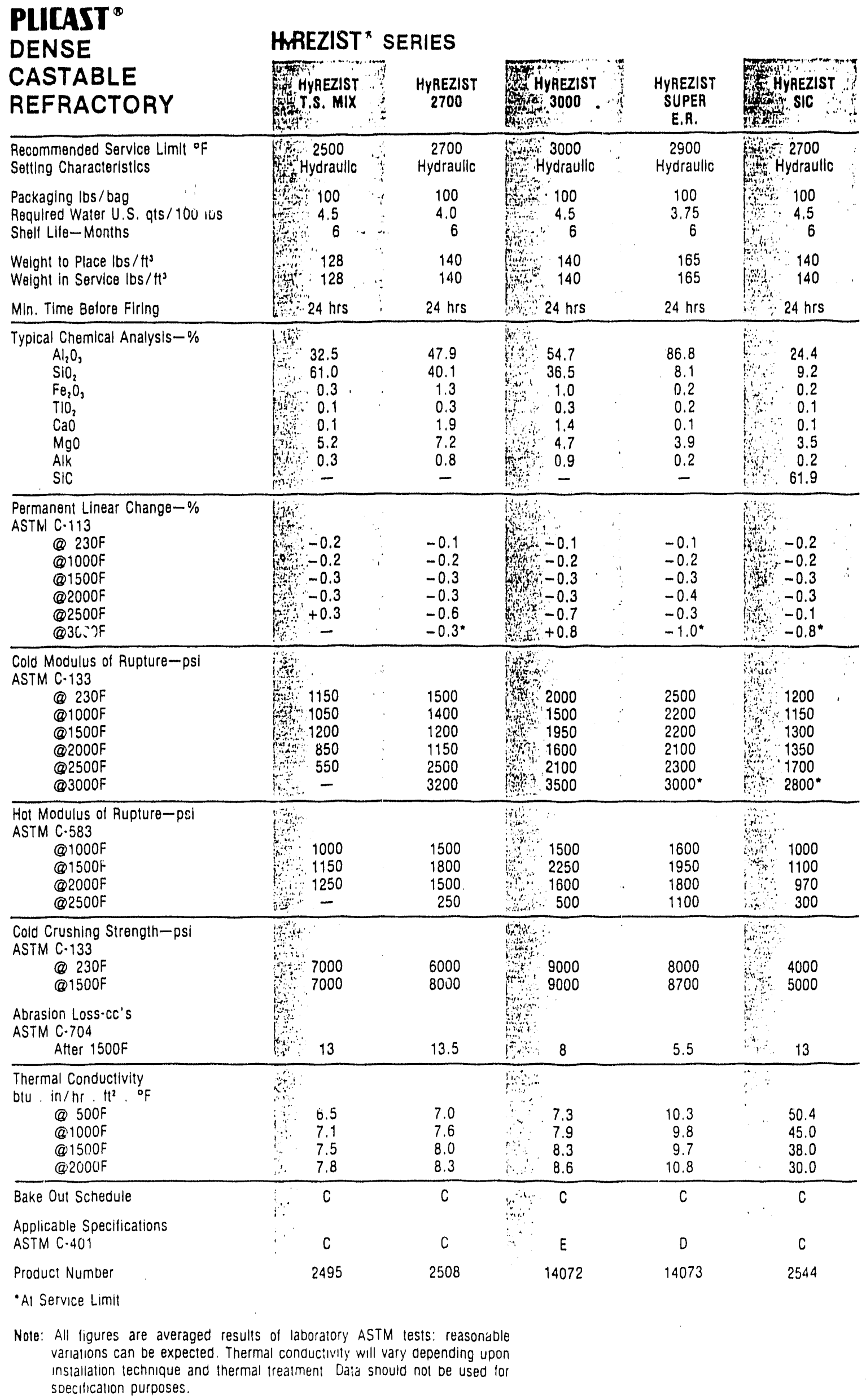


PLICAST

DENSE

CASTABLE REFRACTORY

FMYMOR ' SERIES

REFRACTORY

$\begin{array}{cc}\text { PLICAST } & \text { PLICAST } \\ \text { HyMOR } & \text { HYMO } \\ 2800 & 3000\end{array}$

PLICAST

HYMOR
3100

PLICAST

HYMOA

HYMOR

3100

VIBE

CAST

Recommended Service Limit of

Setting Characteristlcs

Packaging lbs / bag

Required Water U.S. qts / 100 los

Shelf Life-Months

Weight to Place lbs/ $/ \mathrm{ft}^{3}$

Weight in Service lbs / $\mathbb{t t}^{\mathrm{s}}$

Min. Time Before Firing

CAST

Typical Chemical Analysis- $\%$ $\mathrm{Al}_{2} \mathrm{O}_{3}$

$\mathrm{SiO}_{2}$

$\mathrm{Fe}_{2} \mathrm{O}_{3}$

$\mathrm{TlO}_{2}$

$\mathrm{CaO}$

$\mathrm{MgO}$

2800

3000

3100

3100

SPECIAL

PLICAST PLICAST

HYMOR

3100

MYMOR

SPECIAL

VIBE

$3100 \quad 3100$

Hydraulic Hydraulic:

25003000

Hydraulic Hydraulic

100
3.5
6

1003100

4.25 in $\quad 3.75$

6.

100

3.0

100

Hydraullo

ydraulic

Hydraulic

100

$2.75 \quad 3.25$

140.145

$140, \quad 145$

$24 \mathrm{hrs}, 24 \mathrm{hrs}$

150165

165

46.8 का 49.5

46.8

49.5

49.57

$1.3 \div \quad 1.0$

$1.519 \quad 1.6$

$3.6 \div \quad 2.5$

0.2 o. 0.3

0.3

0.6

$43.6 \cdots$

1.01 .2

$1.6-1.9$

$2.5 \% \quad 1.4$

$0.3 \quad 0.1$

$0.6 \quad 0.2$

$\begin{array}{rr}6 & 6 \\ 172 & 160 \\ 172 & 160\end{array}$

0.6

Permanent Linear Change-\%

ASTM C. 113

(1) 230F

(a) $1000 \mathrm{~F}$

(d) $1500 \mathrm{~F}$

@2000F

Q2500F

@3000F

\begin{tabular}{|c|c|c|}
\hline $\begin{array}{l}-0.1 \\
-0.2 \\
-0.3 \\
-0.5 \\
+0.2 \\
+0.4\end{array}$ & $\begin{array}{r}-0.1 \\
-0.1 \\
-0.2 \\
-0.3 \\
0.3 \\
-0.6\end{array}$ & $\begin{array}{l}0.0 \\
-0.1 \\
-0.2 \\
-0.2 \\
-0.4 \\
-0.5\end{array}$ \\
\hline
\end{tabular}

0.2

$24 \mathrm{hrs}$

$24 \mathrm{hrs}$

2.5

100

4.25
6

167

167

24 hrs

$24 \mathrm{hrs}$

190 *

Cold Modulus of Rupture - ps

ASTM C. 133

(1) 230F

@1000F

(1500F

(6)2000F

@2500F

@3000F

1100
1150
1150
1200
1500
1800
130
130
270

$-0.1$

$-0.2$

$-0.2$

$-0.2$

$+0.3$

$+0.7$

\begin{tabular}{r|r}
70.9 .9 & 62.6 \\
15.9 & 32.7 \\
1.2 & 0.9 \\
1.9 & 1.5 \\
1.4 & 1.4 \\
0.1 & 0.1 \\
0.2 & 0.2
\end{tabular}

62.6

32.7

0.9

1.5

1.4.

28.4

28.4
66.5

66.5
0.3

0.3
0.2

3.9

$0.2 \quad 0.2$

93.0 .

Hot Modulus of Rupture-psi

ASTM C.583

@1500F

@2000F

(62500F

$2700 \quad 3400$

1600
1600
1900
2200
2700
3400

0.0
-0.1
-0.2
-0.2
+0.4
+0.8

-0.1
-0.2

$-0.3$

$-0.3$

$+0.4$

$-0.1$

0
0.0
-0.1

$-0.2 \%$

$-0.2$

$+0.5$

$-0.1$

$-0.1$

$-0.2$

$-0.2$

$-0.4$

$-1.2$

4.1.

4.1
0.3

0.6

1.2

$0.1,10$

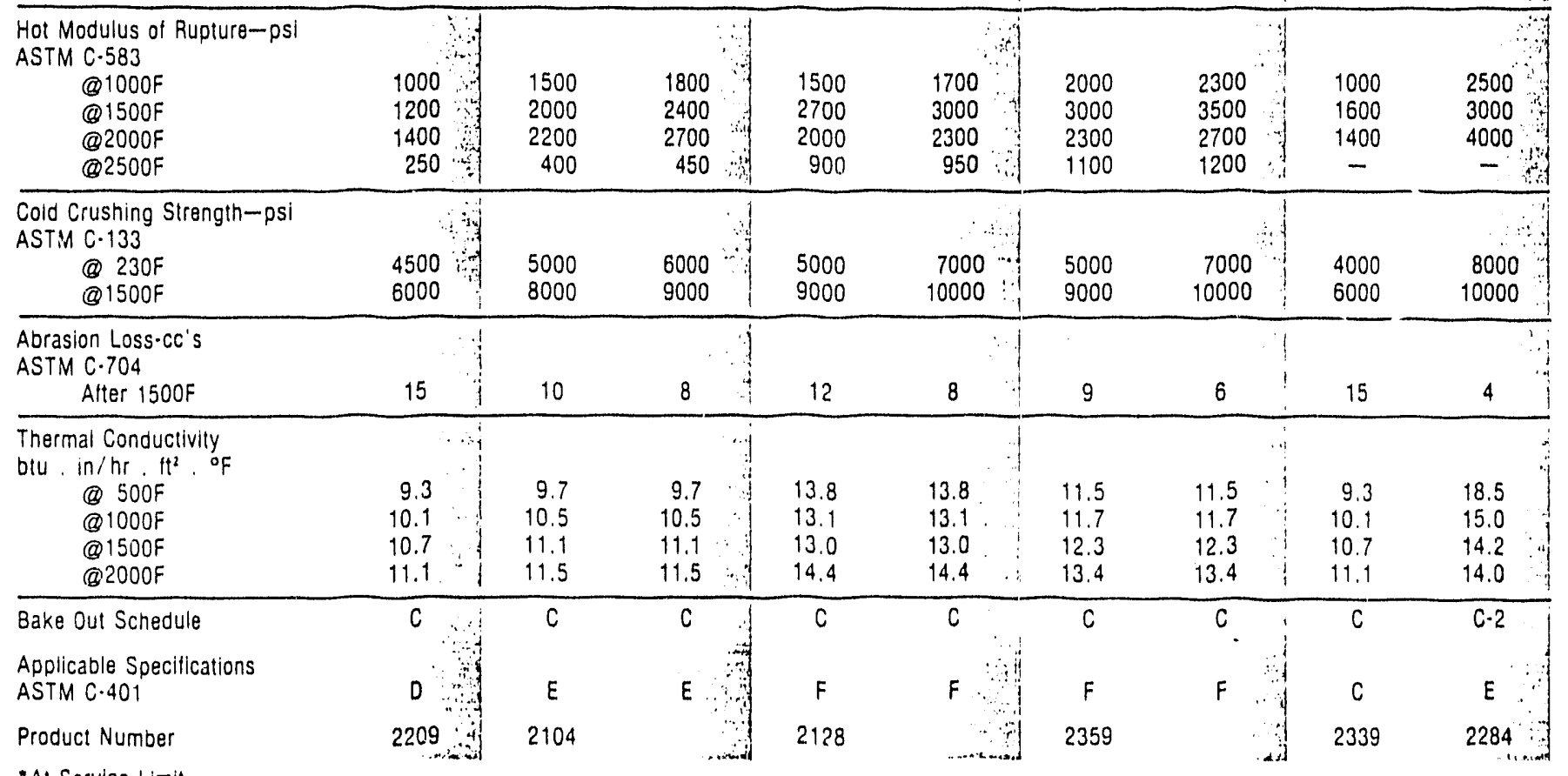

-Al Service Limit

2300
$3400 \quad 2900$

\begin{tabular}{l|l} 
& \\
2100 & 2000 \\
1700 & 1750 \\
2250 & 2000 \\
2500 & 2500 \\
2600 & 3000 \\
3200 & 3800
\end{tabular}

2300
2050
2350
2950
3500
4300

$-$

0.1
0.0
-0.1
-0.2
-0.3
-0.3
-1.5

Note: All figures are averaged results of laboratory ASTM tests: reasonable varlations can be expected. Thermal conductivity will vary depinding upon installation technique and thermal treatment. Data snould not be used for specification purposes. 
PLICAST ${ }^{\circ}$

\begin{tabular}{|c|c|c|c|c|c|c|c|c|}
\hline $\begin{array}{l}\text { INSULATING } \\
\text { CASTABLE REFRACTORY }\end{array}$ & $\begin{array}{l}\text { PLICAST } \\
\text { AIRLITE }\end{array}$ & 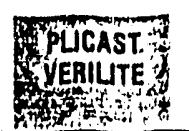 & $\begin{array}{l}\text { PLICAST } \\
\text { LWII-20 }\end{array}$ & $\begin{array}{l}\text { PLICAST } \\
\text { IWI-20 } \\
\text { TROWL MIX }\end{array}$ & $\begin{array}{l}\text { PLICAST } \\
. \text { LWI-22 }\end{array}$ & $\begin{array}{l}\text { PLICAST } \\
\text { (W)-24 } \\
\text { (W) }\end{array}$ & $\begin{array}{l}\text { PLICAST } \\
\text { LWI-26 }\end{array}$ & 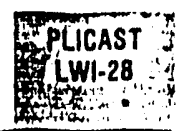 \\
\hline $\begin{array}{l}\text { Rec. Service Limil of-Exposed } \\
\text { Rec. Service Limlt of-Backup } \\
\text { Setting Characleristics }\end{array}$ & $\begin{array}{l}1500 \\
1800 \\
\text { Hydraulic }\end{array}$ & Hydraulic & $\begin{array}{c}2000 \\
\text { Hydraulic }\end{array}$ & $\begin{array}{l}2000 \\
y^{2}\end{array}$ & $\begin{array}{l}2200 \\
\text { Hydraulic }\end{array}$ & $\begin{array}{l}2450 \\
4\end{array}$ & $\begin{array}{c}2600 \\
\text { Hydraullc }\end{array}$ & $\begin{array}{l}2800 \\
\text { Hydraullc } \\
\text { Hen }\end{array}$ \\
\hline $\begin{array}{l}\text { Packaging lbs / bag } \\
\text { Required Water U.S. qts } / 100 \text { lbs } \\
\text { Shell Life-Months }\end{array}$ & $\begin{array}{l}40 \\
24 \\
12\end{array}$ & $\begin{array}{l}50 \\
22 \\
12\end{array}$ & $\begin{array}{r}50 \\
11.5 \\
12\end{array}$ & $\begin{array}{ll}50 \\
12 \\
12\end{array}$ & $\begin{array}{l}50 \\
10 \\
12\end{array}$ & a 14.5 & $\begin{array}{r}100 \\
14.5 \\
9\end{array}$ & $\begin{array}{rl}0 & 50 \\
0 & 6 \\
5 & 9\end{array}$ \\
\hline 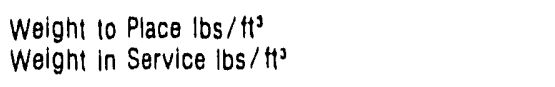 & $\begin{array}{l}27 \\
27\end{array}$ & $\begin{array}{l}x+37 \\
37\end{array}$ & $\begin{array}{l}55 \\
55\end{array}$ & 60 & $\begin{array}{l}65 \\
65\end{array}$ & 880 & $\begin{array}{l}80 \\
80\end{array}$ & 80 \\
\hline Min. Time Betore Firing & $48 \mathrm{hrs}$ & $448 \mathrm{hrs}$ & $24 \mathrm{hrs}$ & 24 hrs & 24 hrs & a $24 \mathrm{hrs}$ & $24 \mathrm{hrs}$ & $24 \mathrm{hrs}$ \\
\hline $\begin{array}{l}\text { Typical Chemical Analysis - \% } \\
\mathrm{Al}_{2} \mathrm{O}_{3} \\
\mathrm{SiO}_{2} \\
\mathrm{Fe}_{2} \mathrm{O}_{3} \\
\mathrm{TIO}_{2} \\
\mathrm{CaO} \\
\mathrm{MgO} \\
\mathrm{Alk} \\
\mathrm{Alk}\end{array}$ & $\begin{array}{r}14.0 \\
33.3 \\
5.3 \\
0.1 \\
35.4 \\
8.8 \\
2.9\end{array}$ & $\begin{array}{r}15.5 \\
38.7 \\
5.8 \\
0.3 \\
30.6 \\
6.9 \\
6 \\
6 \\
\end{array}$ & $\begin{array}{r}39.6 \\
31.5 \\
5.4 \\
1.5 \\
19.5 \\
0.8 \\
1.4 \\
\end{array}$ & 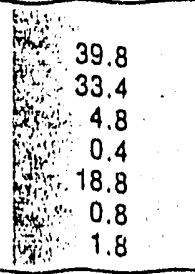 & $\begin{array}{r}41.0 \\
34.0 \\
4.4 \\
0.8 \\
17.2 \\
0.7 \\
1.7\end{array}$ & 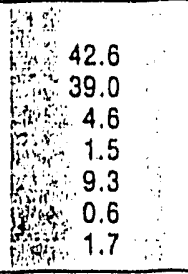 & $\begin{array}{r}51.3 \\
36.9 \\
1.0 \\
1.3 \\
7.1 \\
0.3 \\
1.3\end{array}$ & $\begin{array}{r}5 \\
54.2 \\
36.3 \\
0.8 \\
0.8 \\
0.5 \\
5.7 \\
0.2 \\
1.5 \\
\end{array}$ \\
\hline $\begin{array}{l}\text { Permanent Linear Change- } \% \\
\text { ASTM C. } 113 \\
@ 230 \mathrm{~F} \\
@ 1000 \mathrm{~F} \\
@ 1500 \mathrm{~F} \\
@ 200 \mathrm{~F} \\
@ 2500 \mathrm{~F} \\
@ 3000 \mathrm{~F}\end{array}$ & $\begin{array}{l}-0.3 \\
-0.9 \\
-1.6 \\
= \\
= \\
-\end{array}$ & 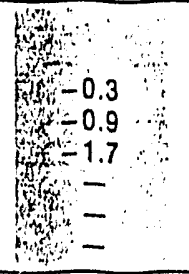 & $\begin{array}{l}-0.3 \\
-0.8 \\
-1.0 \\
-1.2 \\
- \\
-\end{array}$ & $\begin{array}{l}x-0.5 \\
-1.0 \\
-1.3 \\
-1.5 \\
= \\
-\end{array}$ & $\begin{array}{l}-0.3 \\
-0.7 \\
-0.8 \\
-1.0 \\
-1.3^{*} \\
-\end{array}$ & $\begin{array}{l}x \\
-0.2 \\
-0.4 \\
-0.6 \\
-0.7 \\
-1.3^{*}\end{array}$ & $\begin{array}{l}-0.2 \\
-0.3 \\
-0.3 \\
-0.4 \\
+1.2 \\
+0.5\end{array}$ & $\begin{array}{r}1 \\
-0.2 \\
0.3 \\
-0.3 \\
-0.5 \\
+1.6 \\
-0.2^{*}\end{array}$ \\
\hline $\begin{array}{l}\text { Cold Modulus of Rupture-psi } \\
\text { ASTM C- } 133 \\
@ 230 F \\
@ 1000 F \\
@ 1500 F \\
@ 200 F \\
@ 2500 F \\
@ 3000 F\end{array}$ & $\begin{array}{l}90 \\
50 \\
50 \\
- \\
= \\
-\end{array}$ & $\begin{array}{l}150 \\
70 \\
7= \\
2= \\
4=\end{array}$ & $\begin{array}{l}175 \\
125 \\
125 \\
125 \\
- \\
-\end{array}$ & $\begin{array}{r}7 y \\
100 \\
100 \\
100 \\
150\end{array}$ & $\begin{array}{l}200 \\
150 \\
150 \\
150 \\
175^{*} \\
-\end{array}$ & 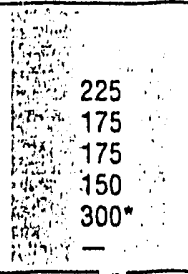 & $\begin{array}{l}320 \\
200 \\
200 \\
130 \\
350 \\
480^{*} \\
\end{array}$ & $\begin{array}{r}350 \\
250 \\
300 \\
300 \\
400 \\
4000^{*} \\
\end{array}$ \\
\hline $\begin{array}{l}\text { Hot Modulus of Rupture-psi } \\
\text { ASTM C.583 } \\
@ 1000 \mathrm{~F} \\
@ 1500 \mathrm{~F} \\
@ 200 \mathrm{~F} \\
@ 2500 \mathrm{~F} \\
\end{array}$ & $\begin{array}{l}\bar{z} \\
\bar{z}\end{array}$ & $\begin{array}{l}4= \\
y= \\
y= \\
y=\end{array}$ & $\begin{array}{r}90 \\
100 \\
75 \\
-\end{array}$ & $\begin{array}{r}75 \\
75 \\
7 \\
5\end{array}$ & $\begin{array}{r}150 \\
1500 \\
75 \\
-\end{array}$ & $\begin{array}{l}150 \\
160 \\
150 \\
1\end{array}$ & $\begin{array}{r}200 \\
220 \\
160 \\
80 \\
\end{array}$ & $\begin{array}{r}200 \\
250 \\
200 \\
200 \\
80\end{array}$ \\
\hline $\begin{array}{l}\text { Cold Crushing Strength-psl } \\
\text { ASTM C-133 } \\
\text { @ } 230 \mathrm{~F} \\
\text { @ } 1500 \mathrm{~F}\end{array}$ & $\begin{array}{l}200 \\
100\end{array}$ & $\begin{array}{l}200 \\
125\end{array}$ & $\begin{array}{l}600 \\
400\end{array}$ & $\begin{array}{l}500 \\
300\end{array}$ & $\begin{array}{l}600 \\
500\end{array}$ & $\begin{array}{l}3 \\
5 \\
500\end{array}$ & $\begin{array}{r}1000 \\
750\end{array}$ & $\begin{array}{l}1100 \\
750\end{array}$ \\
\hline $\begin{array}{l}\text { Thermal Conductivity } \\
\text { btu. In } / \mathrm{hr} \cdot \mathrm{Ht}^{2} .{ }^{\circ} \mathrm{F} \\
@ 500 \mathrm{~F} \\
@ 100 \mathrm{~F} \\
@ 1500 \mathrm{~F} \\
@ 2000 \mathrm{~F} \\
\end{array}$ & $\begin{array}{l}0.6 \\
0.7 \\
1.0 \\
- \\
\end{array}$ & $\begin{array}{r}1.0 \\
1.2 \\
1.5 \\
-1\end{array}$ & $\begin{array}{l}1.2 \\
1.3 \\
1.7 \\
- \\
\end{array}$ & $\begin{array}{r}1.3 \\
1.4 \\
1.8 \\
- \\
\end{array}$ & $\begin{array}{l}1.8 \\
2.1 \\
2.5 \\
3.0 \\
\end{array}$ & $\begin{array}{r} \\
2 \\
2.3 \\
2.5 \\
2.8 \\
\quad 3.7 \\
\end{array}$ & $\begin{array}{l}2.3 \\
2.5 \\
2.8 \\
3.7 \\
\end{array}$ & $\begin{array}{r}\quad \\
\quad 2.5 \\
\quad 2.7 \\
\because \quad 3.0 \\
\end{array}$ \\
\hline Bake Out Schedule & B & $B$ & 8 & $\because: B$ & $B$ & $\because B$ & 8 & $B$ \\
\hline $\begin{array}{l}\text { Applicable Specifications } \\
\text { ASTM C. } 401\end{array}$ & - & & 0 & 00 & P & 0 & R & s \\
\hline Product Number & 16001 & 16002 & 16005 & 16012 & 16015 & 16007 & 16008 & 16009 \\
\hline
\end{tabular}

- At Service Limir

Note: All figures are averaged results of laboratory ASTM tests: reasonable variations can be expected. Thermal conductivity will vary depending upon installation technique and thermal treatment. Data should not be used for specilication durposes. 
Pllaul

\begin{tabular}{|c|c|c|c|c|c|c|c|c|c|}
\hline $\begin{array}{l}\text { DENSE } \\
\text { GUNNING MIXES }\end{array}$ & $\begin{array}{l}\text { PLIGUN } \\
\text { HYDRO MIX }\end{array}$ & $\begin{array}{l}\text { PLIGUN } \\
\text { TUFF MIX }\end{array}$ & $\begin{array}{l}\text { PLIGUN } \\
2800\end{array}$ & $\begin{array}{l}\text { PLIGUN } \\
48\end{array}$ & $\begin{array}{l}\text { PLIGUN } \\
3000\end{array}$ & $\begin{array}{l}\text { PLIQUN } \\
\text { TURBO MIX }\end{array}$ & $\begin{array}{l}\text { PLIGUN } \\
3100 \\
\text { SPECIAL. }\end{array}$ & $\begin{array}{l}\text { PLIGUN } \\
\text { SIC } 80\end{array}$ & $\begin{array}{l}\text { PLIGLIN } \\
\text { HYAEZIST }\end{array}$ \\
\hline $\begin{array}{l}\text { Recommended Service Limit of } \\
\text { Setting Characteristics }\end{array}$ & $\begin{array}{c}2400 \\
\text { Hydraulic }\end{array}$ & $\begin{array}{l}2500 \\
\text { Hydraulic }\end{array}$ & $\begin{array}{c}2800 \\
\text { Hydraullc }\end{array}$ & $\begin{array}{c}2900 \\
\text { Hydraulic }\end{array}$ & $\begin{array}{l}3000 \\
\text { Hydraulic }\end{array}$ & $\begin{array}{l}3000 \\
\text { Hydraulic }\end{array}$ & $\begin{array}{l}3100 \\
\text { Hydraulle }\end{array}$ & $\begin{array}{l}2700 \\
\text { Hydraullc }\end{array}$ & $\begin{array}{l}2700 \\
\text { Hydraullc }\end{array}$ \\
\hline $\begin{array}{l}\text { Packaging lbs / bag } \\
\text { Shelf Lile-Months }\end{array}$ & $\begin{array}{ll}80 \\
12\end{array}$ & $\begin{array}{l}80 \\
12\end{array}$ & $\begin{array}{l}80 \\
12\end{array}$ & $\begin{array}{l}80 \\
12\end{array}$ & \begin{tabular}{rr|}
80 & \\
9 &
\end{tabular} & $\begin{array}{r}80 \\
9\end{array}$ & $\begin{array}{r}80 \\
9\end{array}$ & $\begin{array}{r}80 \\
9\end{array}$ & $\begin{array}{r}80 \\
9\end{array}$ \\
\hline $\begin{array}{l}\text { Weight to Place lbs/ } \mathrm{tt}^{\mathrm{s}} \\
\text { Weight in Service lbs / } \mathrm{ft}^{3}\end{array}$ & $\begin{array}{l}116 \\
116\end{array}$ & $\begin{array}{l}120 \\
120\end{array}$ & $\begin{array}{l}120 \\
120\end{array}$ & $\begin{array}{l}125 \\
125\end{array}$ & 130 & $\begin{array}{l}145 \\
145\end{array}$ & $\begin{array}{l}135 \\
135\end{array}$ & $\begin{array}{l}136 \\
136\end{array}$ & $\begin{array}{ll}130 \\
130\end{array}$ \\
\hline Min. Time Betore Firing & $24 \mathrm{hrs}$. & $24 \mathrm{hrs}$ & $24 \mathrm{hrs} / 4$ & $24 \mathrm{hrs}$ & $24 \mathrm{hrs}$ & $24 \mathrm{hrs}$ & 24 hrs $\ldots$ & $24 \mathrm{hrs}$ & $24 \mathrm{hrs}+\sin ^{2}$ \\
\hline $\begin{array}{l}\text { Typical Chemical Analysis - \% } \\
\mathrm{Al}_{2} \mathrm{O}_{3} \\
\mathrm{SlO}_{2} \\
\mathrm{Fe}_{2} \mathrm{O}_{3} \\
\mathrm{TlO}_{2} \\
\mathrm{CaO} \\
\mathrm{MgO} \\
\mathrm{Alk} \\
\mathrm{SiC}\end{array}$ & 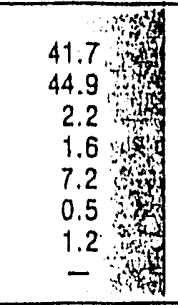 & $\begin{array}{r}49.5 \\
38.8 \\
1.4 \\
1.8 \\
7.1 \\
0.2 \\
0.9 \\
-\end{array}$ & $\begin{array}{l}44.7 \\
46.6 \\
1.3 \\
1.2 \\
4.0 \\
0.3 \\
1.3 \\
-3\end{array}$ & $\begin{array}{r}45.5 \\
47.6 \\
1.4 \\
1.7 \\
1.4 \\
0.4 \\
1.2 \\
-\end{array}$ & $\begin{array}{r}50.6 \\
40.5 \\
1.2 \\
1.2 \\
2.7 \\
0.2 \\
0.4 \\
-\end{array}$ & $\begin{array}{r}78.7 \\
13.4 \\
1.4 \\
2.1 \\
3.7 \\
0.1 \\
0.2 \\
-\end{array}$ & $\begin{array}{r}59.1 \\
35.3 \\
1.2 \\
1.5 \\
2.3 \\
0.2 \\
0.3 \\
-\end{array}$ & $\begin{array}{r}13.6 \\
4.8 \\
0.3 \\
0.1 \\
3.9 \\
0.1 \\
0.2 \\
77.5\end{array}$ & $\begin{array}{r}57.8 \\
33.1 \\
1.0 \\
1.3 \\
5.8 \\
0.2 \\
0.6 \\
-2.4 \\
\end{array}$ \\
\hline $\begin{array}{l}\text { Permanent Linear Change-\% } \\
\text { ASTM C.113 } \\
@ 230 \mathrm{~F} \\
@ 1000 \mathrm{~F} \\
@ 1500 \mathrm{~F} \\
@ 2000 \mathrm{~F} \\
@ 2500 \mathrm{~F} \\
@ 3000 \mathrm{~F}\end{array}$ & $\begin{array}{l} \\
-0.3 \\
-0.3 \\
-0.4 \\
-0.6 \\
-1.5 \\
-1.40 \\
\end{array}$ & $\begin{array}{l}-0.3 \\
-0.3 \\
-0.4 \\
-0.3 \\
+1.1 \\
-\end{array}$ & $\begin{array}{l}\text { 1. } \\
-0.2 \\
-0.3 \\
-0.4 \\
-0.5 \\
-0.9 \\
-0.1\end{array}$ & $\begin{array}{l}-0.2 \\
-0.3 \\
-0.4 \\
-0.5 \\
-0.9 \\
-0.1\end{array}$ & 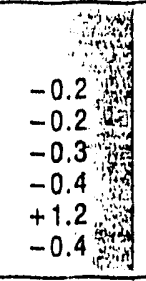 & $\begin{array}{l}-0.2 \\
-0.3 \\
-0.3 \\
-0.2 \\
-0.6 \\
-1.4 \\
\end{array}$ & $\begin{array}{r} \\
-0.2 \\
-0.3 \\
-0.3 \\
-0.2 \\
+0.3 \\
+0.2\end{array}$ & $\begin{array}{l}-0.2 \\
-0.3 \\
-0.3 \\
-0.2 \\
-0.7 \\
-\end{array}$ & $\begin{array}{l}\text { r. } \\
-0.1 . \\
-0.2 \\
-0.2 \\
-0.3 \\
-0.3 \\
-0.9\end{array}$ \\
\hline $\begin{array}{l}\text { Cold Modilus of Ruplure-psi } \\
\text { ASTM C.133 } \\
@ 230 \mathrm{~F} \\
@ 1000 \mathrm{~F} \\
@ 1500 \mathrm{~F} \\
@ 2000 \mathrm{~F} \\
@ 2500 \mathrm{~F} \\
@ 3000 \mathrm{~F}\end{array}$ & $\begin{array}{l}700 \\
400 \\
400 \\
350 \\
1800 \\
-\end{array}$ & $\begin{array}{r}1000 \\
700 \\
750 \\
650 \\
1950 \\
-\end{array}$ & $\begin{array}{r}400 \\
400 \\
350 \\
450 \\
1600 \\
2000\end{array}$ & $\begin{array}{r}100 \\
100 \\
110 \\
200 \\
500 \\
1700^{*}\end{array}$ & $\begin{array}{l}0 \\
800 \\
500 \\
550 \\
430 \\
750 \\
1700\end{array}$ & $\begin{array}{r}1050 \\
750 \\
700 \\
550 \\
1300 \\
2700\end{array}$ & $\begin{array}{rr}600 & \\
400 & 1 \\
470 & \\
500 & \\
1000 & \\
1600 & \end{array}$ & $\begin{array}{r}1000 \\
450 \\
600 \\
600 \\
2700 \\
-\end{array}$ & $\begin{array}{r}1200 \\
1000 \\
800 \\
900 \\
1500 \\
1800\end{array}$ \\
\hline $\begin{array}{l}\text { Hot Modulus of Rupture-psi } \\
\text { ASTM C.583 } \\
@ 1000 \mathrm{~F} \\
@ 1500 \mathrm{~F} \\
@ 2000 \mathrm{~F} \\
@ 2500 \mathrm{~F}\end{array}$ & $\begin{array}{l}4 \\
400 \\
450 \\
400 \\
-\quad 3\end{array}$ & $\begin{array}{l}650 \\
800 \\
500 \\
100\end{array}$ & $\begin{array}{l}400 \\
400 \\
500 \\
100\end{array}$ & $\begin{array}{r}80 \\
150 \\
150 \\
50\end{array}$ & $\begin{array}{l}600 \\
600 \\
650 \\
110\end{array}$ & $\begin{array}{l}650 \\
730 \\
600 \\
200\end{array}$ & $\begin{array}{l}400 \\
550 \\
650 \\
150\end{array}$ & $\begin{array}{r}400 \\
650 \\
1000 \\
100\end{array}$ & $\begin{array}{r}600 \\
1000 \\
700 \\
200\end{array}$ \\
\hline $\begin{array}{l}\text { Cold Crushing Sirength-psi } \\
\text { ASTM C.133 } \\
\text { @ 230F } \\
\text { @1500F }\end{array}$ & 1800 & $\begin{array}{l}2200 \\
1850\end{array}$ & 1600 \% & $\begin{array}{l}300 \\
300\end{array}$ & $\begin{array}{l}2200 \\
2000\end{array}$ & $\begin{array}{l}2400 \\
2000\end{array}$ & $\begin{array}{l}1600 \\
1500\end{array}$ & $\begin{array}{l}2500 \\
2000\end{array}$ & $\begin{array}{l}4000 \\
3500\end{array}$ \\
\hline $\begin{array}{l}\text { Thermal Conductlvity } \\
\text { btu. In } / \mathrm{hr} . \mathrm{tt}^{2} .{ }^{\circ} \mathrm{F} \\
@ 500 \mathrm{~F} \\
@ 1000 \mathrm{~F} \\
@ 1500 \mathrm{~F} \\
@ 2000 \mathrm{~F}\end{array}$ & $\begin{array}{ll} & \\
3.9 & 4 \\
4.7 & 4 \\
5.7 & \\
7.4 & \end{array}$ & $\begin{array}{l}3.9 \\
4.7 \\
5.7 \\
7.4\end{array}$ & $\begin{array}{ll} & \\
3.9 & \\
4.7 & \\
5.7 & \\
7.4 & \end{array}$ & $\begin{array}{l}3.9 \\
4.7 \\
5.7 \\
7.4\end{array}$ & $\begin{array}{ll}4.4 & \\
5.3 & \\
6.5 & \\
8.3 & \cdots\end{array}$ & $\begin{array}{r}5.9 \\
7.1 \\
8.7 \\
11.3\end{array}$ & $\begin{array}{l}4.7 \\
5.6 \\
6.8 \\
8.6\end{array}$ & $\begin{array}{l}72.0 \\
64.0 \\
55.0 \\
47.0\end{array}$ & $\begin{array}{l}4.4 \\
5.3 \\
6.5 \\
8.3\end{array}$ \\
\hline Bake Out Schedule & 8 & $B$ & B a d & $B$ & $B \div$ & $B$ & 8 & $B$ & $B$ \\
\hline $\begin{array}{l}\text { Applicable Specifications } \\
\text { ASTM C.401 }\end{array}$ & $B$. & C & 0 & $E$ & E & $E$ & $F$ & 0 & $D \cdots \because$ \\
\hline Product Number & 14015 & 14033 & $13028=0$ & 13003 & 2336 & 13014 & 14031 & 13030 & $13041 \ldots$ \\
\hline
\end{tabular}

- Al Service Limit

Note: All flgures are averaged results of laboratory ASTM lests on gunned samples: reasonable variations can be expected. Thermal conductivity will vary depend. ing upon installation technique and thermal treatment. Data should not be used for speciflcation purposes. 


\section{PUIGU1"}

INSULATING GUNNING MIXES

Rec. Service Limit of-Exposed

Rec. Service Limit of-Backup

Setting Characteristics

Packaging los/bag

Shelf Life-Months

Weight to Place ibs $/ t^{3}$

Weight in Service los $/ \mathrm{tt}^{3}$

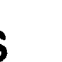

Min. Time Before Firing

Typical Chemical Analysis - \%

$\mathrm{Al}_{2} \mathrm{O}_{3}$

$\mathrm{SiO}_{2}$

$\mathrm{Fe}_{2} \mathrm{O}_{3}$

$\mathrm{CaO}_{2}$

$\mathrm{MgO}$

Alk

\begin{tabular}{lc} 
PLIGUN & VERILITE \\
\hline 00 & 1500 \\
& 1800 \\
Hydraulic
\end{tabular}

50

Tyydraulic

50 政 50

12

$38 \quad 38$

38 38

48 hrs $24 \mathrm{hrs}$

\section{PUGUN} โWI-22

2200

Permanent Line

(a) $230 \mathrm{~F}$

@1000F

Q1500F

(a)200F

(2500F

@3000F

$\begin{array}{rr} & \\ 16.4 & 30.9 \\ 36.7 & 21.9 \\ 6.7 & 9.6 \\ 0.4 & 1.5 \\ 27.5 & 21.6 \\ 9.3 & 8.2 \\ 2.6 & 2.7\end{array}$

Cold Modulus of Rupture-ps

ASTM C-133

(4) $230 \mathrm{~F}$

Q1000F

\$1500F

$@ 2000 \mathrm{~F}$

(82500F

@3000F

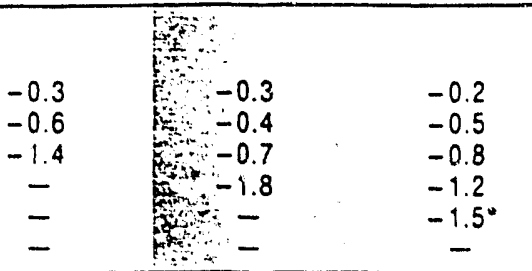

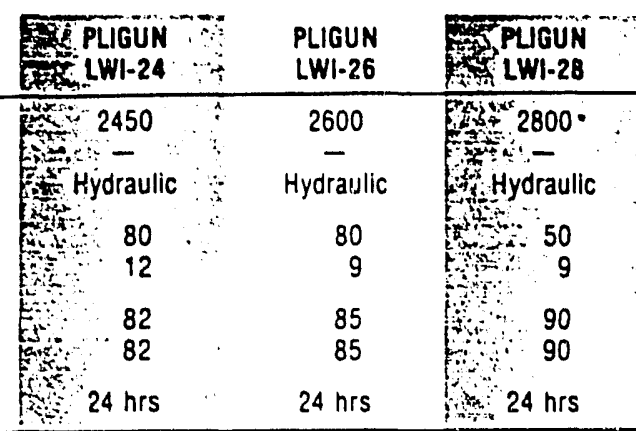

Hot Mooulus of Rupture-psi

ASTM C.583

(1000F

(8)1500F

Q2000:

(2500F

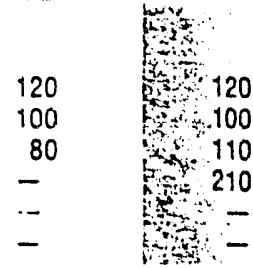

$\begin{array}{rrr}44.0 & & 44.9 \\ 34.6 & & 41.7 \\ 2.7 & & 1.4 \\ 0.3 & & 1.3 \\ 16.0 & 8.5 \\ 0.3 & \because & 0.2 \\ 2.1 & \because & 1.5\end{array}$

Coid Crusning Strenghn-psi

ASTM C. 133

(4) $230 \mathrm{~F}$

Q1500F

(2)

pris

Thermal Conouctivity

otu in $/ \mathrm{hr}$. $\mathrm{H}^{2}$ of

$500 \mathrm{~F}$

(a) $1000 \mathrm{~F}$

Q1500F

\&2000F

Bahe Out Schedule

100
50
-
-

Applicable Soecifications

ASTM C. 101

Produc: Numoer

250

250

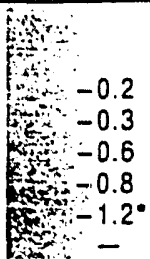

$\begin{array}{rrr}57.4 & & 53.1 \\ 37.6 & \because & 36.0 \\ 0.9 & & 0.9 \\ 0.8 & & 0.5 \\ 1.2 & & 7.1 \\ 0.2 & \therefore & 0.3 \\ 1.5 & & 1.6\end{array}$

- Al Service Limi

250

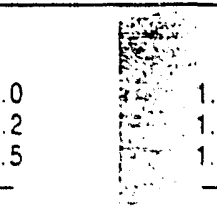

$\begin{array}{cc}150 \\ 0 & 125 \\ 0 & 150 \\ 0 & 150 \\ - & 15 J^{\prime}\end{array}$

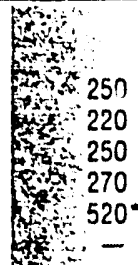

(ain

f.

$-0.2 \quad \because-0.2$

.0 .3

$-0.4$

$-0.3$

0.5

$+0.6$

$+1.3$

$+1.4^{*} \quad+1.7^{*}$

Note: All ilgures are averaged results of laboratory ASTM tes:s on gunnec samoles reasonaole vanlations can be expected Thermal conquctivity will var, oepeno. ing coon insiallation tecnnique and thermal treatment. Data snowis no: ae used tor specification purposes 


\begin{tabular}{|c|c|c|c|c|c|}
\hline $\begin{array}{l}\text { FLIDSTIX' } \\
\text { SERVICING MIXES }\end{array}$ & $\begin{array}{c}\text { PLISTIX } \\
\text { SPRAYTITE } \\
\text { B } \\
\end{array}$ & $\begin{array}{l}\text { PLISTIX } \\
\text { SUPER }\end{array}$ & $\begin{array}{l}\text { PLISTIX } \\
900 \mathrm{~F}\end{array}$ & $\begin{array}{l}\text { PLISTIX } \\
\text { SR-68 }\end{array}$ & $\begin{array}{l}\text { PLISTIX } \\
\text { SR-90 }\end{array}$ \\
\hline $\begin{array}{l}\text { Recommended Service Limit of } \\
\text { Setting Characteristics }\end{array}$ & $\begin{array}{l}2500 \\
\text { Sillicate }\end{array}$ & $\begin{array}{l}2700 \\
\text { Silicate }\end{array}$ & $\begin{array}{c}3400 \\
\text { Chemical }\end{array}$ & $\begin{array}{l}3100 \\
\text { Chemical }\end{array}$ & $\begin{array}{c}3400 \\
\text { Chemical }\end{array}$ \\
\hline $\begin{array}{l}\text { Packaging } \\
\text { Shelf Life-Months }\end{array}$ & $\begin{array}{r}80 \mathrm{lbs} / \mathrm{bag} \\
12 \mathrm{~g}+\mathrm{thH}\end{array}$ & $\begin{array}{l}100 \mathrm{Ibs} \text { : bag } \\
12\end{array}$ & $50 \mathrm{lbs} / \mathrm{pail}$ & $50 \mathrm{lbs} /$ pail & $\begin{array}{c}50 \mathrm{lbs} / \mathrm{pai} \\
-2-3\end{array}$ \\
\hline $\begin{array}{l}\text { Weight to Place los } / \mathrm{ft}^{\mathrm{s}} \\
\text { Weight in Service } \mathrm{lbs} / \mathrm{ft}^{\mathrm{s}}\end{array}$ & ant18 & $\begin{array}{l}110 \\
110\end{array}$ & 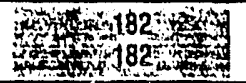 & $\begin{array}{l}160 \\
140\end{array}$ & 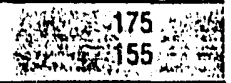 \\
\hline Min. Time Betore Firing & ros iNongessy & None & 4 & None & She Noneitidy \\
\hline $\begin{array}{l}\text { Typical Chemical Analysis - \% } \\
\mathrm{Al}_{2} \mathrm{O} \\
\mathrm{SiO}_{2} \\
\mathrm{Fe}_{2} \mathrm{O}_{3} \\
\mathrm{TiO}_{2} \\
\mathrm{CaO} \\
\mathrm{MgO} \\
\mathrm{Alk} \\
\mathrm{P}_{2} \mathrm{O} \\
\end{array}$ & 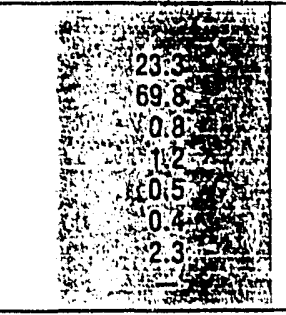 & $\begin{array}{c}33.9 \\
63.2 \\
1.1 \\
1.7 \\
0.4 \\
0.3 \\
4.3 \\
- \\
\end{array}$ & 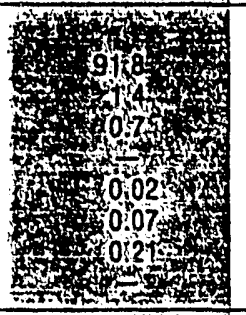 & $\begin{array}{r}69.0 \\
25.5 \\
0.9 \\
1.0 \\
0.1 \\
0.1 \\
0.2 \\
2.7\end{array}$ & 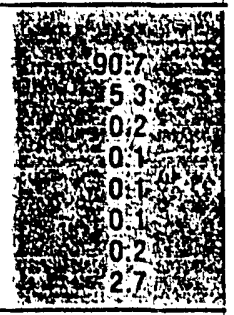 \\
\hline Product Number & $4+4+754$ w & $i 7504$ & 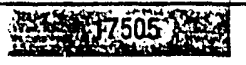 & 17704 & $x^{2}+20208$ \\
\hline
\end{tabular}

\section{PRISTUXS \\ INJEC.TITE \\ INJECTION MIXES}

Rec. Service Limit of (exposed)

Setting Characteristics

\begin{tabular}{|c|c|c|}
\hline Packaging & $50 \mathrm{lbs} /$ pail & $3080 \mathrm{lbs} / \mathrm{bag}$ \\
\hline Required Water U.S. ats / $100 \mathrm{lbs}$ & - & $+6+6.5 \mathrm{Az}$ \\
\hline Shelf Life-Months & 3 & Th 6 fidit \\
\hline $\begin{array}{l}\text { Weight to Place } \mathrm{lbs} / \mathrm{t}^{3} \\
\text { Weight in Service } \mathrm{lbs} / \mathrm{tt}^{3}\end{array}$ & $\begin{array}{l}75 \\
30\end{array}$ & 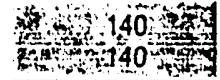 \\
\hline $\begin{array}{l}\text { Permanent Linear Change- } \% \\
2000^{\circ} \mathrm{F} \\
2300^{\circ} \mathrm{F} \\
2700^{\circ} \mathrm{F} \\
\end{array}$ & $\begin{array}{c}-3.5 \\
-7.5 \\
-\end{array}$ & 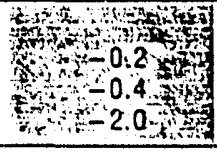 \\
\hline $\begin{array}{l}\text { Thermal Conductivity } \\
\text { btu. in } / \mathrm{hr} . \mathrm{ft}^{2} .{ }^{\circ} \mathrm{F} \\
@ 500 \mathrm{~F} \\
@ 1000 \mathrm{~F} \\
@ 1500 \mathrm{~F} \\
@ 2000 \mathrm{~F}\end{array}$ & $\begin{array}{l}0.6 \\
0.7 \\
1.0 \\
-\end{array}$ & 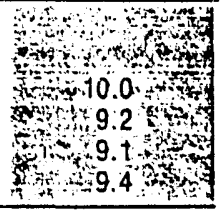 \\
\hline Product Number & 17618 & $\$ 17602^{2}$ \\
\hline
\end{tabular}

\begin{tabular}{|c|c|}
\hline MORTARS & 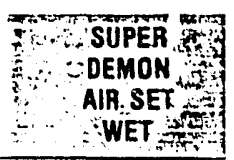 \\
\hline $\begin{array}{l}\text { Recommended Service Limit }{ }^{\circ} \mathrm{F} \\
\text { Settıng Characteristics }\end{array}$ & $\begin{array}{r}2950 \\
\text { A Air }\end{array}$ \\
\hline $\begin{array}{l}\text { Coverage: Ibs per } 1000 \text { Sid. Fire Brick } \\
\text { Packaging los idrum } \\
\text { Shelt Life-Months }\end{array}$ & $\begin{array}{r}350.400 \\
50 \text { or } 100 \\
0 \\
0\end{array}$ \\
\hline $\begin{array}{l}\text { Typical Chemical Analysis-\% } \\
\mathrm{Al}_{2} \mathrm{O} \\
\mathrm{SiO}_{2} \\
\mathrm{Fe}_{i} \mathrm{O} \\
\mathrm{TiO}_{2} \\
\mathrm{CaO} \\
\mathrm{MgO} \\
\mathrm{Alk}\end{array}$ & 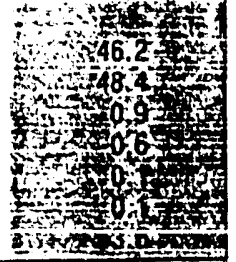 \\
\hline
\end{tabular}

Note:

All figures are averaged results of laboratory ASTM tests: reasonable varlations can be expected. I nermal conaucilvity wiii vary jepenüing upon installation technique and thermal trearment. Data should not be used for specification purposes. 


\section{A Fluid Approach \\ To Combustor \\ Refractory \\ Selections ...}

Have it y :ur way!

Plan a combustor lining that delivers all the inherent advantages of monolithic Plibrico construction... plus.... all the individually selected benefit features you consider most important.

Choices... the choices avaitable arnong the broad range of Plibrico refractories... enable you to select products with properties to precisely match your own operational requirements, to coordinate with your own parameters for cost-effective levels of service. That's the fluid approach, the Plibrico approach, to fluid bed combustor system linings.

You can select among ormulations serving over a spectrum of service temperatures, offering varying alumina contents and densities, delivering varying levels of hot strength and abrasion resistance, providing varying degrees of thermal conductivity and insulation. And all of these choices are yours in materias for either casting or gunning in riace, with plastics also available for selected combustor applications.

You can have it our way, if you choose. You'll see the Plibrico way in the following pages presenting three schematically illustrated combustor systems and the application of selected product combinations currently recominended by Plibrico in this still evolving technology. The significant advantages that are yours with those product combinations are highlighted at the right.

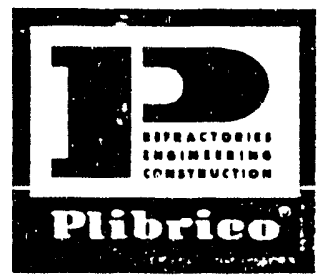

\section{PLIBRICO MONOLITHIC LININGS FOR FLUID BED COMBUSTORS}

\section{You get all these benefits ... and more ... with Plibrico's recommended lining designs}
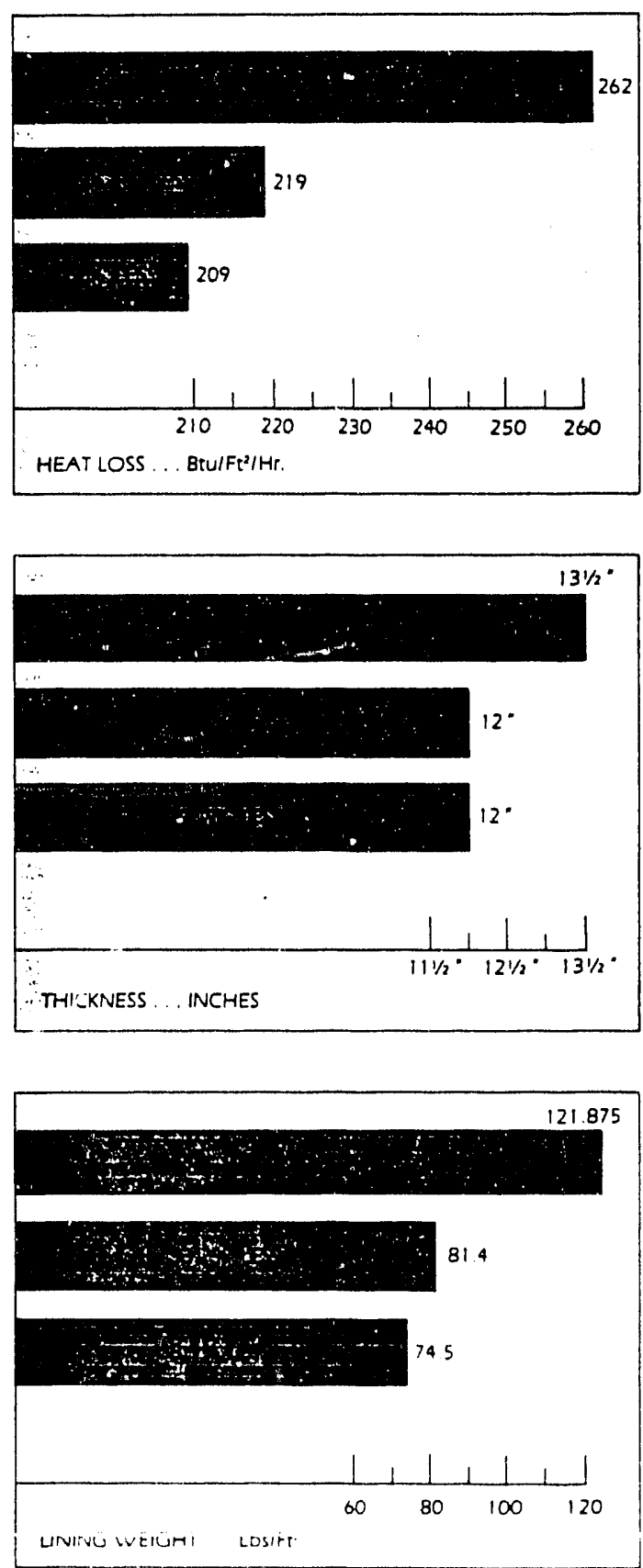

\section{LOWER HEAT LOSS}

... for high thermal efficlency

Look at the valuable reductions in heat loss Plibrico linings achieve compared to ordinary fire brick linings, a graphic demonstration of their superior thermal efficiency. Apply these percentages to your cost for the fuel needed with ordinary construction and you'll welcome the substantial dollar savings, savings that continue throughout the extended life of the Plibrico lining.

\section{THINNER LININGS \\ . . . for reduced vessel size}

Significant to new combustor system designers and buyers alike is the fact that the high thermal efficiencies depicted here result from linings that are $11 \%$ thinner than the fire brick linings. Thus, while maintaining the same internal dimensions to provide the same combustion volumes and gas velocities, external vessel dimensions can be reduced appreciably. yielding desirable companion reductions in sieel quantities and weights, as well as fabricating and erection costs.

\section{LIGHTER LININGS \\ . . . for less structural support}

Clearly shown here are the pronounced weight differences that set Plibrico linings far apart from fire brick linings: they're from $33.2 \%$ to $38.9 \%$ lighter. Consider the synergistic effect of linings that are both lighter and thinner. linıngs that not only contribute to more compact vessel sizing. but also trim down the need for structural support. Plibrico IInings are distinctive. giving you high thermal efficiency plus cost-effective construction. 


\section{Consider these}

\section{Additional Lining}

\section{Features}

Fully Monollthic ...

Every Plibrico lining forms one continuous, tightly knit unit. It's completely free of the countless joints that make a fire brick lining so vulnerable, joints that open with expansion and contraction, allowing excess air infiltration to retard combustion efficiency, leading to costly and premature repairs.

Totally Anchored . . .

Strategically placed anchors embedded throughout the Plibrico lining provide a positive support system to enhance the lining's structural integrity. Engineered to application temperatures, they serve as shock-absorbers allowing for free natural movement while tenaciously holding the lining securely in place.

Rapidly Installed . . .

You'll note from the drawings that gunning refractories predominate, ensuring high speed placement at rates that outstrip those of laid up construction, especially where configurations would require special shapes. Pligun refractories flow freely, quickly building up a lining that molds to any contour, compensating on the spot for any shell irregularities. Even in severe wear zones where its unique properties are so advantageous, Plicast HyMOR 3000 can be rapidly cast.

Unmatched Abrasion

\section{Resistance...}

No conventional castable in its class can withstand abrasion as well as Plicast HyMOR 3000 . It's twice as effective! It's ideally suited to the turbulent, high wear conditions of fluidized beds.

\section{Superb Hot Strength . . .}

High temperature testing re veals that Plibrico hot face refractory selections achieve excellent in-service strengths, making them more resistant to hot load deformation, and prolonging their service life. For example. Plicast HyMOR 3000 has three times the hot srrength. onethird the hot load deformation of conventional castables.

\section{For a Direct Fired Boiler Combustor}

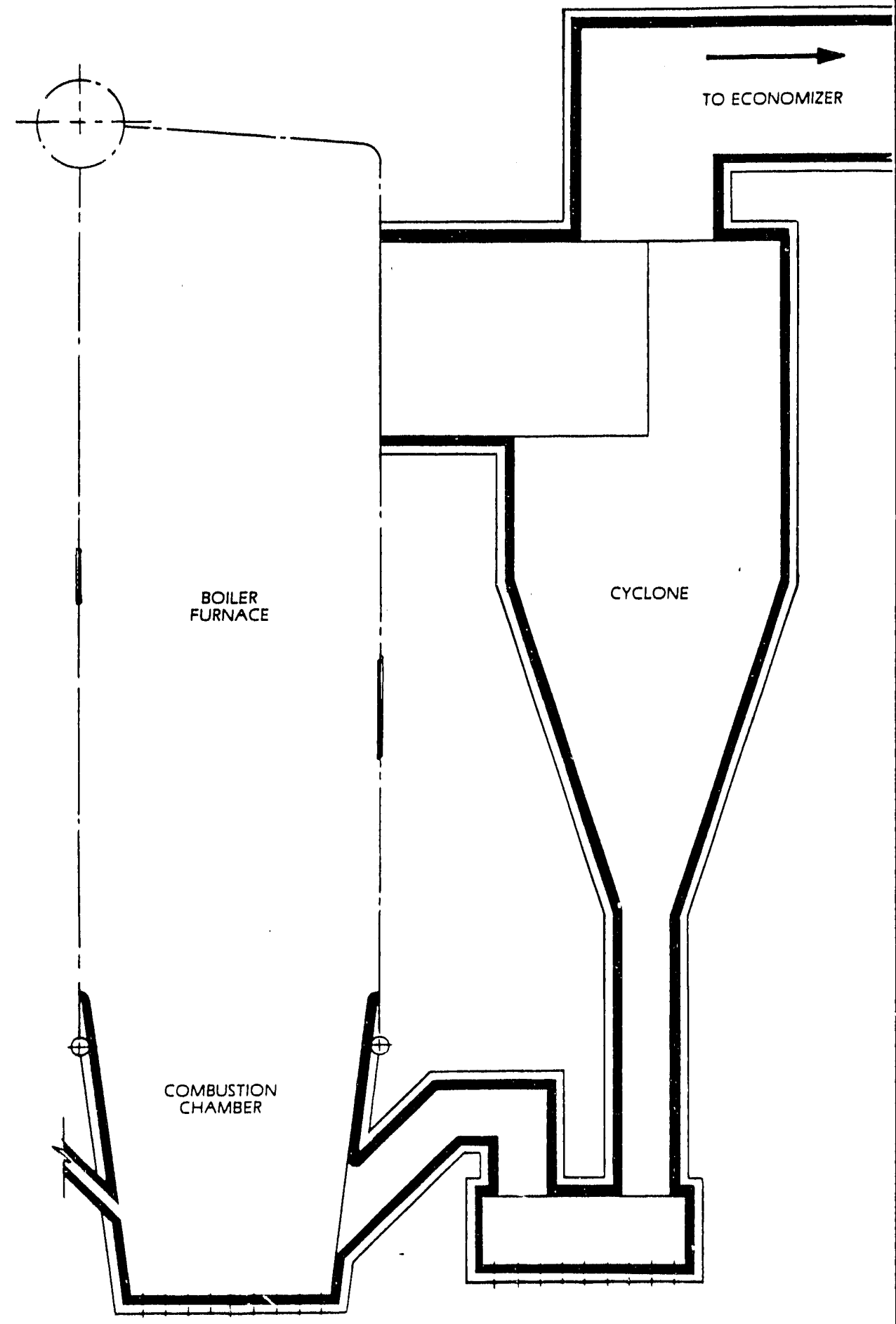




\section{For a Waste Heat Boiler Combustor}

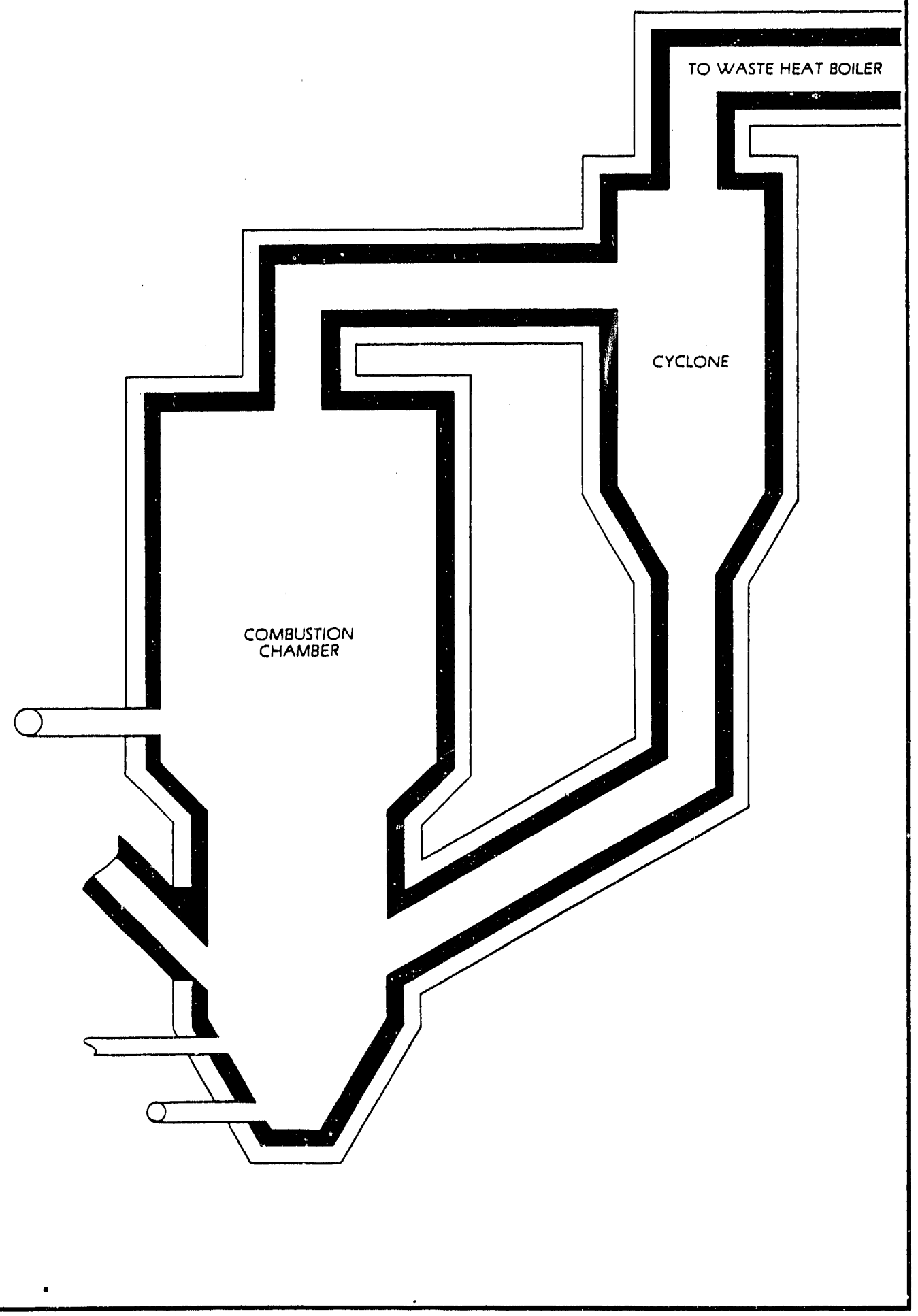

\section{... and these \\ Refractory Propertles}

Pllcast HyMOR 3000

This super duty class castable, a $50 \%$ alumina formulation with the relatively low iron content of $1.10 \%$, serves the full tempera ture range from $200^{\circ} \mathrm{F}$ to $3000^{\circ} \mathrm{F}$. It weighs $145 \mathrm{lb} / \mathrm{ft}^{3}$ in service and offers high load bearing capacity for it has three times the hot strength of conventional super duty castables. In the standard abrasion test its loss is a mere bcc, half that of its conventional counterparts.

\section{Pllgun 3000}

Constituents of this formulation are carefully sized and blended, providing a uniform mix with excellent flow characteristics to assure consistent gunnability. It's a super duty material with a $50 \%$ alumina content and the relative ly low iron content of $1.16 \%$. In service it weighs $129 \mathrm{lb} / \mathrm{ft}^{3}$. Across its full service temperature range, extending from $200^{\circ} \mathrm{F}$ to $3000^{\circ} \mathrm{F}$, it achieves uniformly high hot strengths. It's distinguished by the moderate thermal conductivity that contributes to lower heat loss, and it provides good abrasion resistance, ample to with stand the wear of those areas where it's employed.

\section{Pligun LWI-106 Special}

Formulated for service in the in termediate duty temperature range from $200^{\circ} \mathrm{F}$ to $2000^{\circ} \mathrm{F}$, this is a smooth-gunning mix that's very light in weight, only $36 \mathrm{lb} / \mathrm{ft}^{3}$. For its weight it delivers uniform strength over its entire service range. Its key characteristic lies in its remarkable insulating efficiency, reflecting its markedly low heat storage capacity, its minimal thermal conductivity. 


\section{A Rugged Plastic LIning . . . Gunned at HIgh Speed}

High performance Plibrico plastics excel in this service because they so capably combat chemical attai:k, repelling the adverse reactions generated by wastes and many process products. They not only develop high strengths at operating temperatures, but they're also volume stable, ruggedly resisting thermal shock.

Now, thanks to the unique HyRATE Process, plastics can be gunned at speeds $250 \%$ faster than conventional ramming, and often more. Both installation time and labor expense are effectively reduced. Specially formulated for gunning, Plibrico HyRATE plastics are available in a selection for any service condition.

\section{A Joint-Free Dome ... Cast as a Single Entity}

What could more vividly illustrate the impeccable integrity of Plicast castable construction than these two photos of a one-piece combustor dome, one view taken from below and the other from above. Here you see the unified expanse of a monolith, reacilly formed and cast as one integratect structure. Eliminated is the tedious process of installing costly special shapes.

With its own powerful properties, Plicast HyMOR 3000 further enhances the inherent integrity of this dome's monolithic structure. Superb strength distinguishes PIicast HyMOR 3000 from conventional castables for it attains three times greater hot strengths, withstands hot load deformation three times more effectively. And it's $100 \%$ more resistant to abrasion.
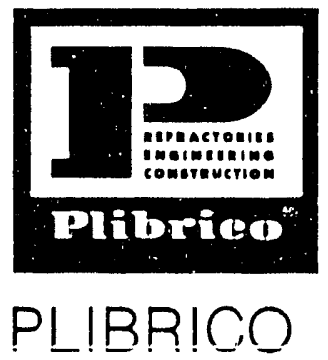
COMPANY

$1800 \mathrm{~N}$ Kingsoury Sireel Chicago IL 60614

Printed in US A Merit 1.86

\section{For an Incinerator/Process Combustor}
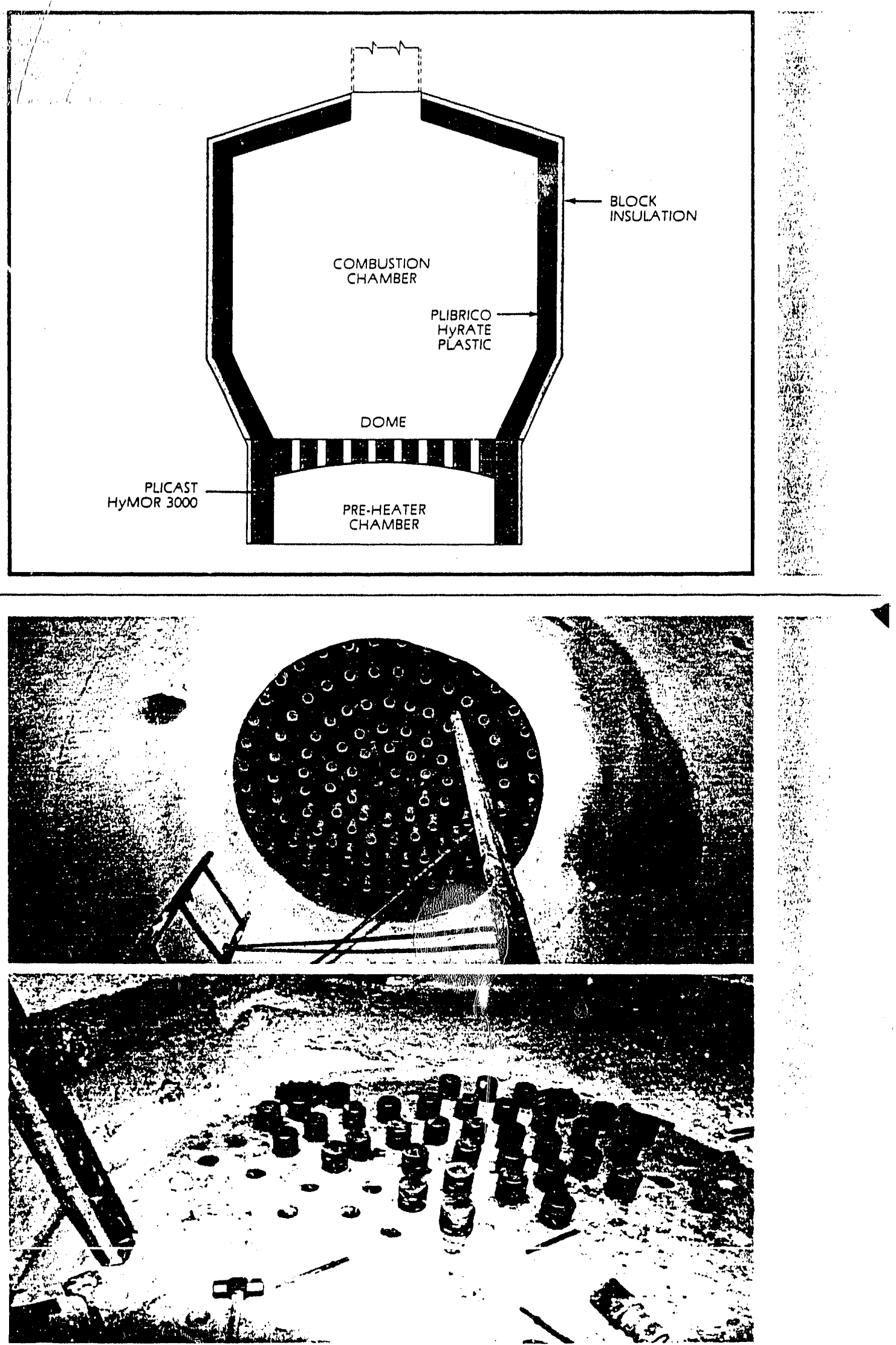
㟔

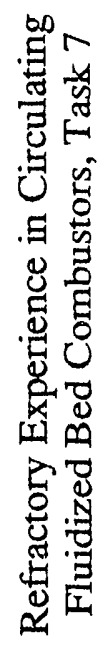

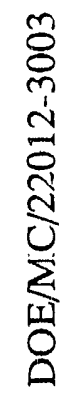



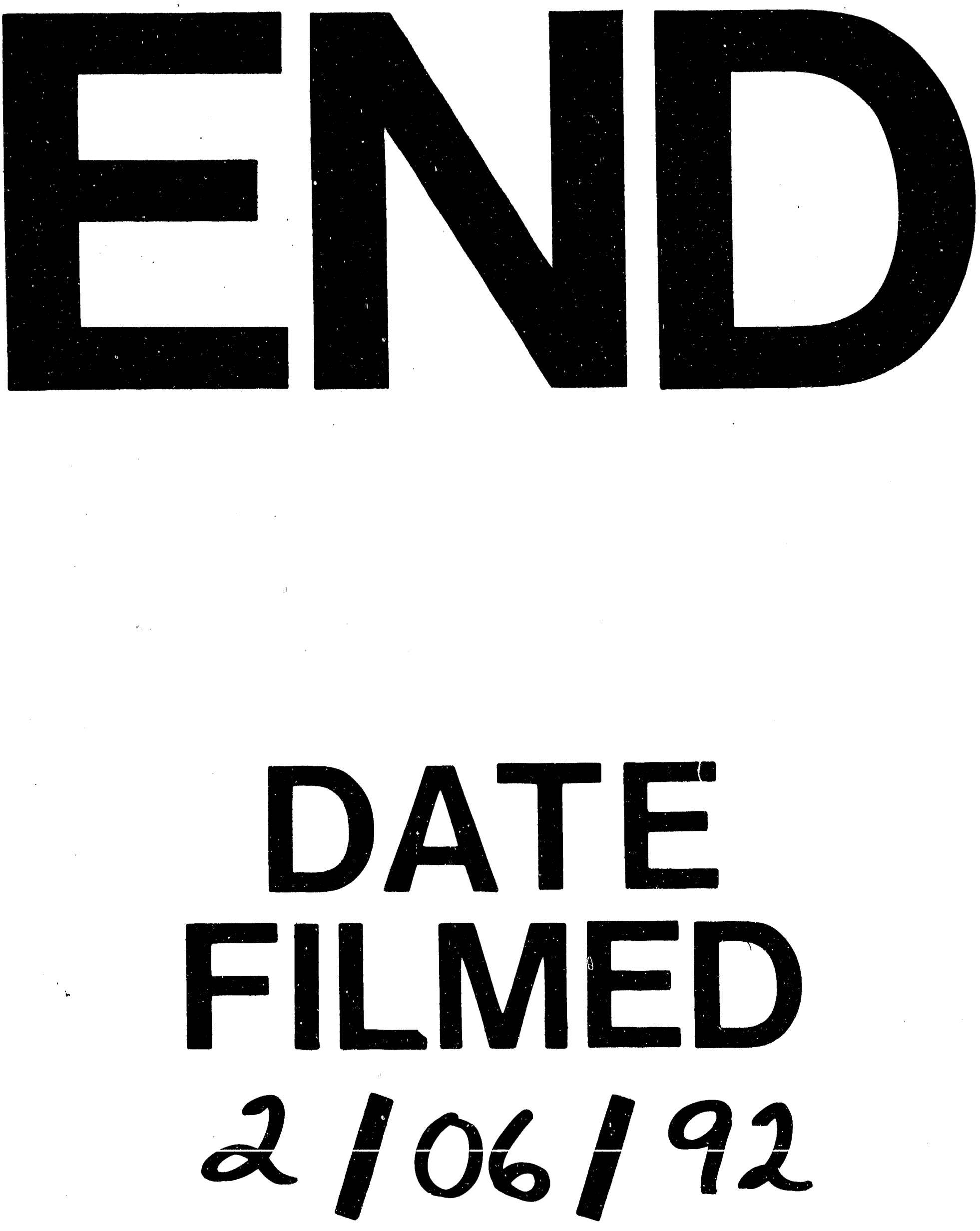

1 
